\title{
Ösztrán vázas vegyületek A- és D-gyürüben történő módosítása
}

Doktori (Ph.D.) értekezés

Bacsa Ildikó

Témavezető:

Dr. Mernyák Erzsébet

egyetemi adjunktus

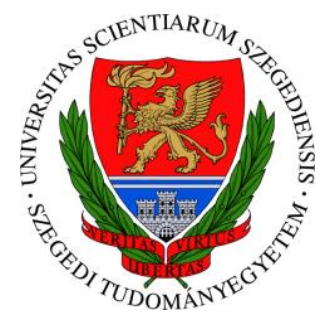

Kémia Doktori Iskola

Szerves Kémiai Tanszék

SZTE TTIK

Szeged

2018 


\section{Tartalom}

1. Bevezetés és célkitüzések..................................................................................... 3

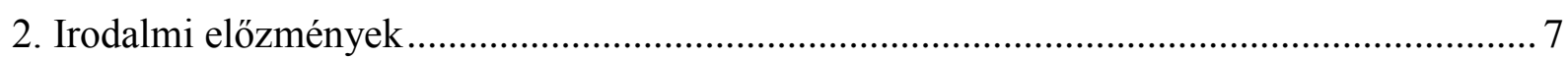

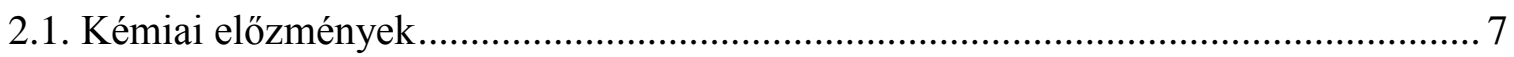

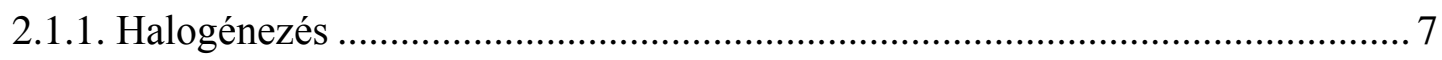

2.1.2. Sonogashira keresztkapcsolás szteroid modellen....................................... 14

2.1.3. Stilbén és benzofurán alapváz előállítása Pd katalizált keresztkapcsolási reakciókban ................................................................................. 18

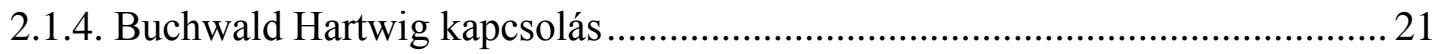

2.1.5. A BODIPY fluoreszcens festékek és ösztronnal képzett konjugátumaik ........ 27

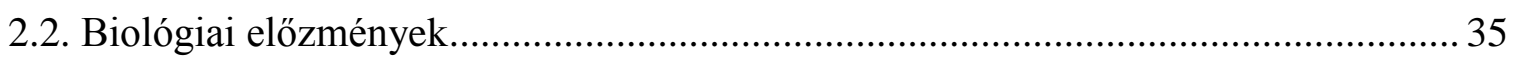

2.2.1. Az A-gyürüben módosított ösztron származékok biológiai vonatkozásai ....... 35

2.2.2. A fluoreszcensen BODIPY-vel jelölt ösztron származékok biológiai

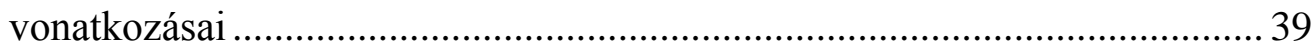

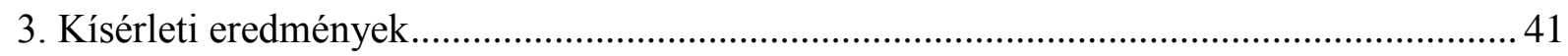

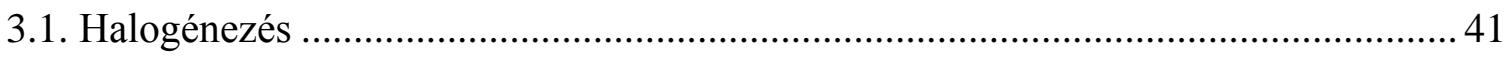

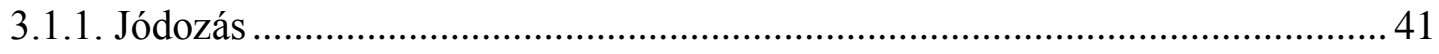

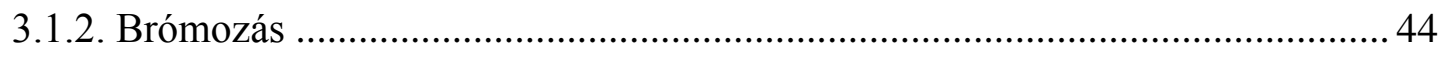

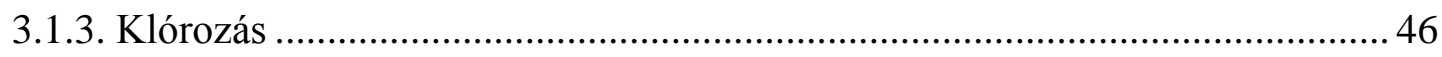

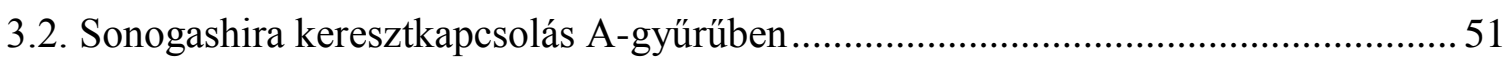

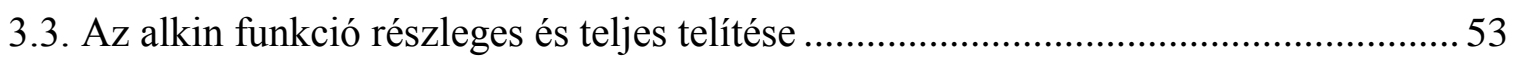

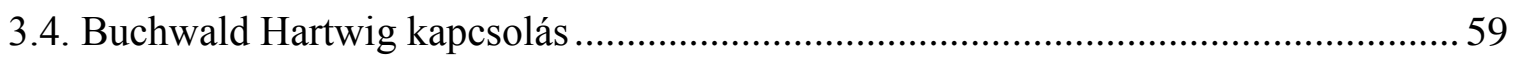

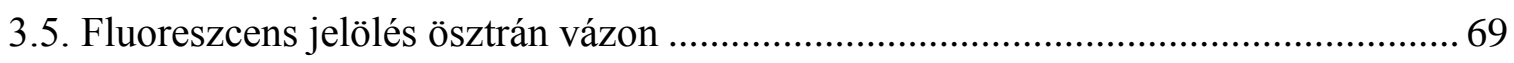

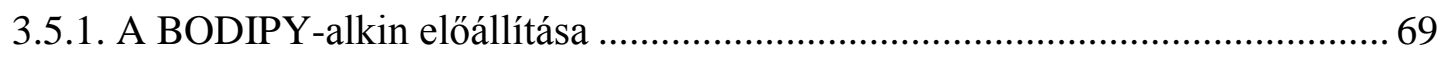

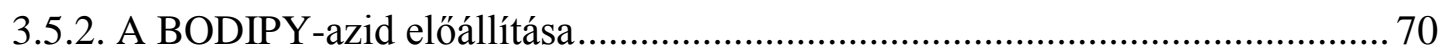

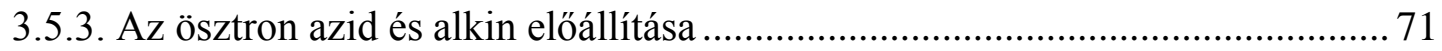

3.5.4. Fluoreszcens jelölés CuAAC reakcióval.................................................... 73

3.6. Enzimgátlási vizsgálatok az A gyürüben szubsztituált vegyületek körében.............. 78 


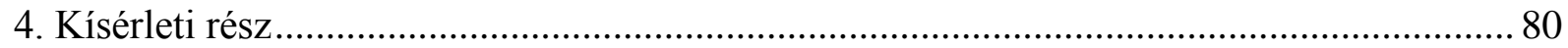

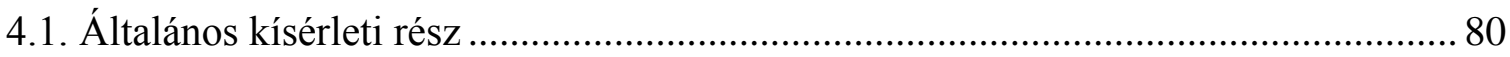

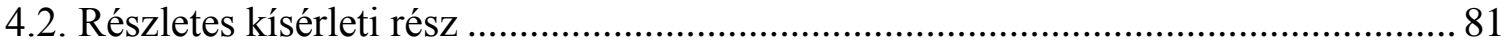

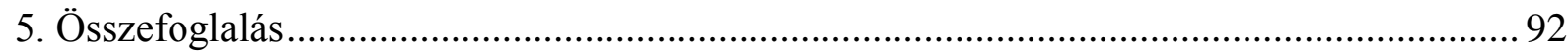

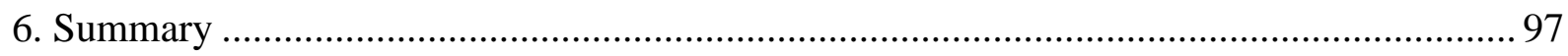

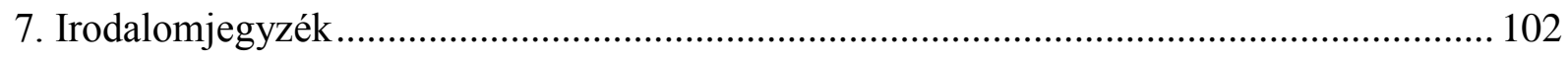

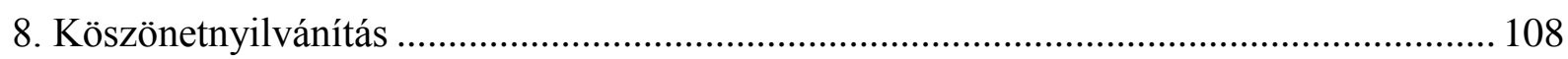

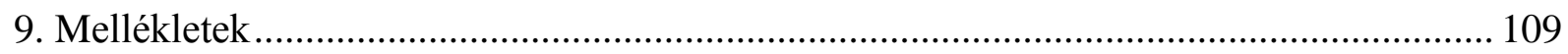




\section{Rövidítések jegyzéke}

17 $\beta$-HSD1

BINAP

BODIPY

CuAAC

DBU

DDQ

DIPEA

DMF

ER

$\mathrm{IC}_{50}$

HSQC

HMBC

NBS

NIS

NCS

NOESY

$\mathrm{PdCl}_{2}\left(\mathrm{PPh}_{3}\right)_{2}$

$\mathrm{Pd}(\mathrm{dba})_{2}$

$\mathrm{Pd}_{2}(\mathrm{dba})_{3}$

$\mathrm{PPh}_{3}$

$\mathrm{Pd}(\mathrm{OAc})_{2}$

$\mathrm{Pd}\left(\mathrm{PPh}_{3}\right)_{4}$

STS

TFA

THF

TMSA

XPhos 17ß-hidroxiszteroid dehidrogenáz 1-es típusú izozim

2,2'-bisz(difenilfoszfino)-1,1'-binaftil)

4,4-Difluoro-4-bora-3a,4a-diaza-s-indacén

réz(I)-katalizált azid-alkin cikloaddíció

1,8-Diazabiciklo(5,4,0)undec-7-én

5,6-diciano-2,3-diklór-1,4-benzokinon

$N, N$-diizopropil-etilamin

$N, N$-dimetilformamid

ösztrogén receptor

az az inhibitor koncentráció, amely az enzim aktivitást 50\%-ra csökkenti

Heteronuclear Single Quantum Coherence, olyan kétdimenziós NMR spektroszkópiai technika, amely két közvetlenül kötésben levő különböző mag közötti kölcsönhatást mutatja

Heteronuclear Multiple Bond Correlation, olyan kétdimenziós NMR spektroszkópiai technika, amely két nem közvetlenül kötésben lévő különböző mag közötti kölcsönhatást mutatja

$N$-brómszukcinimid

$N$-jódszukcinimid

$N$-klórszukcinimid

Nuclear Overhauser Effect Spectroscopy, olyan kétdimenziós NMR spektroszkópiai technika, amely a magok téren keresztüli kölcsön hatásán alapul

bisz-trifenilfoszfán-palládium(II)-klorid

bisz-dibenzilidénaceton-palládium( 0 )

trisz-dibenzilidénaceton-palládium( $(0)$

trifenilfoszfán

palládium(II)-acetát

tetrakisz-trifenilfoszfán-palládium(0)

szteroid-szulfatáz

trifluorecetsav

tetrahidrofurán

trimetilszilil-acetilén

2-diciklohexilfoszfino-2',4',6'-triizopropilbifenil 


\section{Bevezetés és célkitüzések}

A humán emlő daganatok közel 70\%-a hormonfüggő. ${ }^{1}$ Ösztrogénfüggő tumorok kezelésében eredményes megoldást jelenthetnek a hormonmegvonáson alapuló eljárások. Ilyen terápiás megközelítés az ösztrogének bioszintézisének gátlása, amely szintetikusan módosított ösztron származékokkal vagy nem szteroid-alapú hatóanyagokkal is elérhető. A szintetikus ösztronalapú gyógyszerhatóanyagok alkalmazásának korlátot szabhat azok ösztrogén hatása, amely nemkívánatos mellékhatásként jelentkezik. A gyógyszerkémiában ezért külön kihívást jelent a szelektív hatású, ösztron-alapú hatóanyagok kifejlesztése. Az ösztrogének bioszintézisét gátló vegyületek tervezéséhez elengedhetetlenül szükséges az ösztradiol (3) képzödéséhez vezető bioszintetikus útvonalak megismerése. Az ösztrogén hormonok bioszintézisében három enzim; a 17ß-HSD1, a szteroid szulfatáz (STS) és az aromatáz játszik föszerepet (1. ábra). Az enzimek közül az elsőként a STS szerepel, amely a szulfatáz enzimcsaládba tartozó aril-szulfatáz (ARS) és többek között a biológiailag inaktív ösztron-szulfát (1, E1S) ösztronná (2) való átalakulását katalizálja. ${ }^{2-5} \mathrm{~A}$ humán aromatáz enzim a citokróm P450 szupercsaládba tartozik, és a $\mathrm{C}_{19}$-androsztán - $\mathrm{C}_{18}$-ösztron konverziót és az A-gyürü aromatizációját katalizálja. A 17-es oxocsoport sztereospecifikus redukcióját 17-es helyzetü $\beta$ hidroxilcsoporttá a 17ß-hidroxiszteroid-dehidrogenáz 1 enzim végzi. ${ }^{6}$

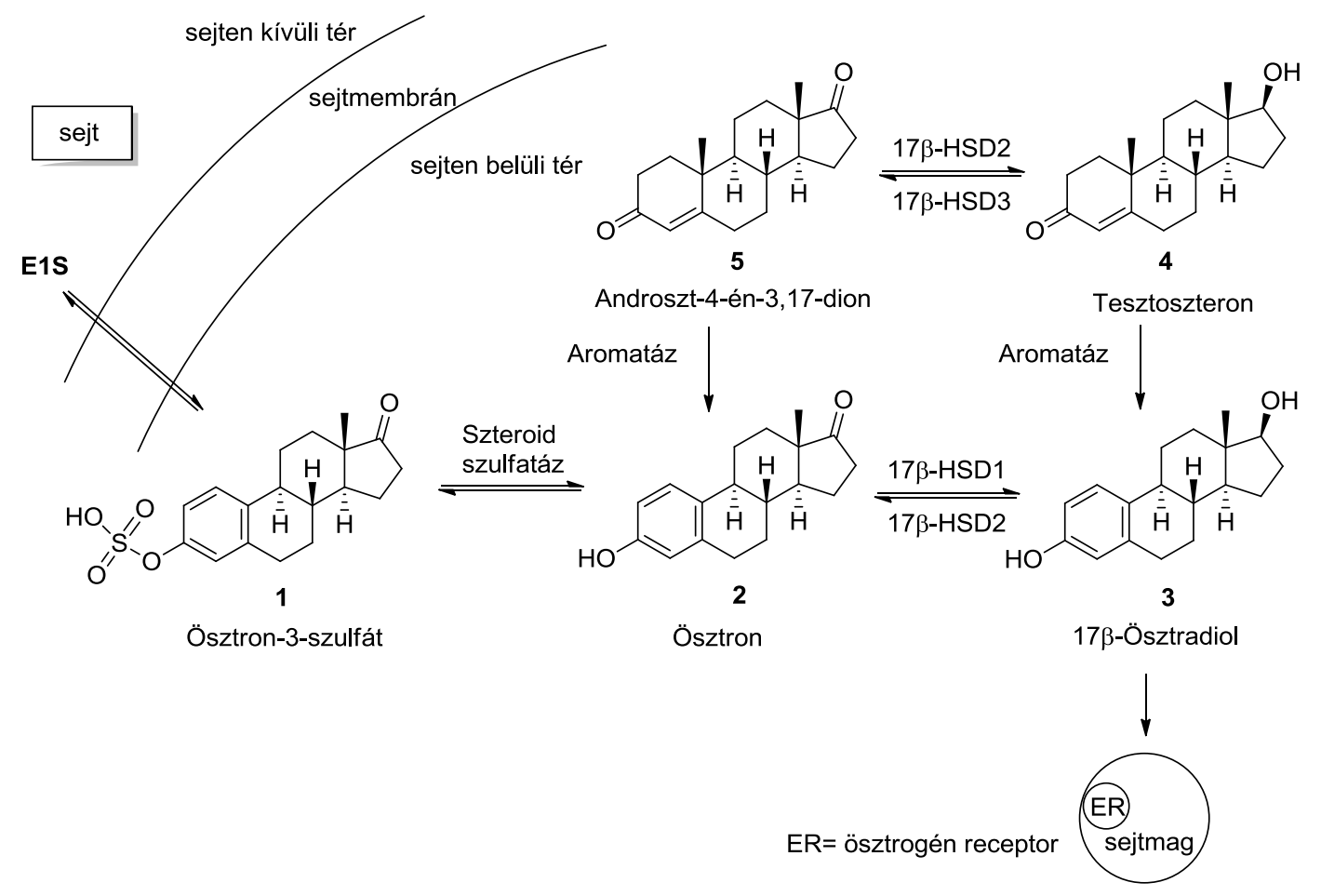

1. ábra Az ösztron (2) és a 17ß-ösztradiol (3) bioszintézise 
Ismert fehérjeszerkezet birtokában adott enzimre célzottan tervezhetők inhibitorok szubsztrátum és termék oldalról egyaránt. Az ösztron jelen esetben két enzimnek terméke (STS és aromatáz), egynek pedig szubsztrátja (17ß-HSD1). Ezen megfontolások alapján ösztron-alapon megfelelő kémiai módosítással akár mindhárom enzim működését gátló vegyületet nyerhetünk. Ez terápiás szempontból előnyös lehet a dózisok csökkentése és a hosszú ideig tartó gyógyszeres kezeléskor fellépő rezisztencia elkerülésére. A legpotensebb ösztron-alapú enzim inhibitorok azonban még nem jutottak el a klinikai alkalmazásig visszamaradó ösztrogenitásuk miatt. Következésképpen az olyan új szintetikus ösztron származékok kifejlesztése, amelyek hormonális aktivitással nem, de egyéb értékes biológiai hatással rendelkeznek, továbbra is fontos kutatási terület. A származékok ösztrogén aktivitásának visszaszorítására több lehetőség is kínálkozik, azonban a potenciális gyógyszerhatóanyagok tervezésénél nem elhanyagolható szempont a szintézis útvonal hatékonysága, nem utolsó sorban a reakciólépések száma és az összhozam. Egyik ilyen lehetöség az ösztron 13-as szénatomjának epimerizálása. Ezáltal megváltozik a C és D gyürük anellációja, ami a teljes váz konformációjára kihat, így megakadályozza a vegyület ösztrogén magreceptorokhoz való kötődését is (2. ábra). ${ }^{7}$
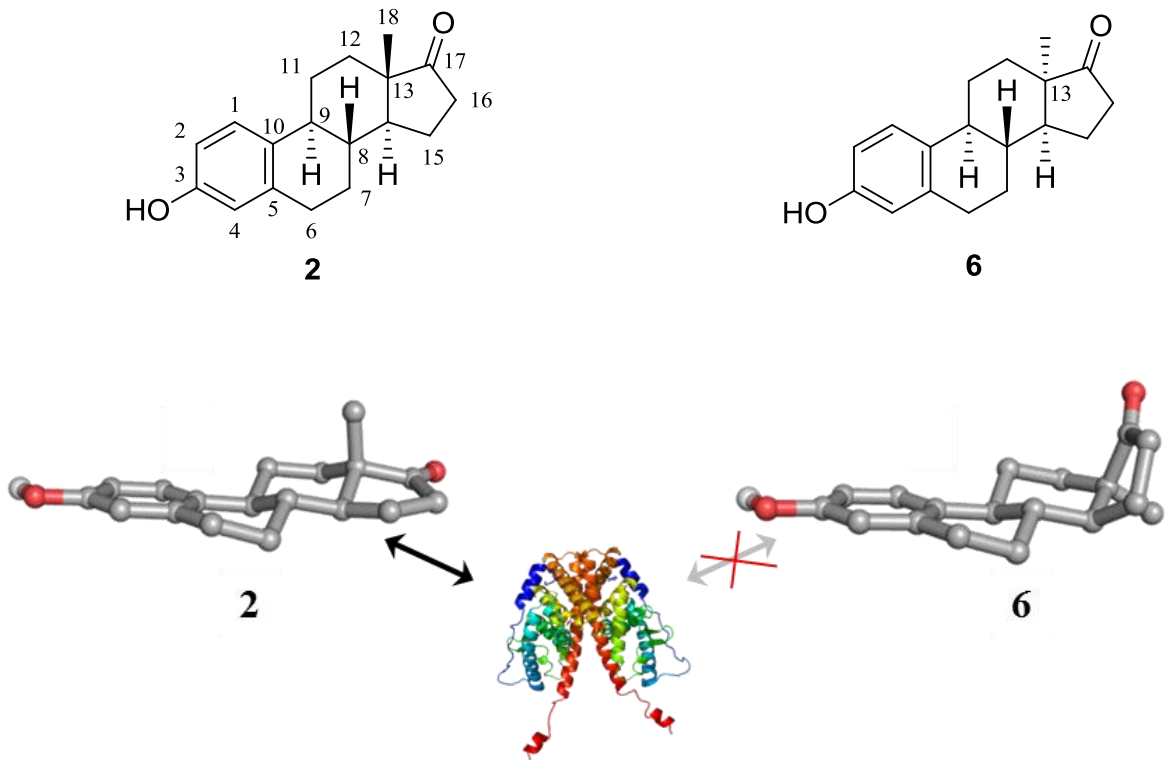

PDB-kód: 1A52

2. ábra Az ösztron (2) és a 13 $\alpha$-ösztron (6) szerkezete és az ösztrogén receptor $\alpha$

A 13a-ösztron (6) előállítása több kutatócsoport fejlesztésének köszönhetően ma már egy egylépéses epimerizációs eljárásban könnyen és hatékonyan megvalósítható. ${ }^{8-10}$ Kutatócsoportunkban az utóbbi két évtizedben számos, a D-gyürü felnyitásával vagy 
gyürütagszámának bővítésével nyert biológiailag aktív 13a-ösztron származékot állítottak elő. ${ }^{11-15}$ Nemcsak a D-, hanem az A-gyürüben módosított származékok is ígéretesek lehetnek biokémiai szempontból, mivel egyes 13 $\alpha$-ösztron sorba tartozó, 3-as helyzetben módosított heterociklusos származékok kiemelkedő antiproliferatív hatást mutatnak több humán női reproduktív tumorsejtvonalon. ${ }^{16}$ Fordulópontot jelentett, amikor a közelmúltban a $13 \alpha$ ösztron alapvegyületröl megállapítottuk, hogy a 17ß-HSD1 enzimhez hasonló affinitást mutat, mint annak ösztron szubsztrátja. ${ }^{17}$ Erre a jelentős eredményre alapozva jelen

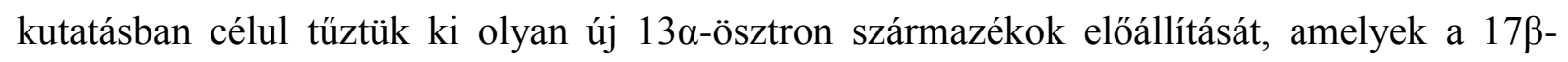
HSD1 enzim gátlásán keresztül ható szelektív, hormonhatástól mentes tumorellenes hatóanyagok lehetnek. Továbbá irodalmi ismereteinkre ${ }^{18,19}$ alapozva célunk volt olyan $13 \alpha$ ösztron származékok előállítása, amelyek a 17ß-ösztradiol (3) bioszintézisében részt vevő enzimek müködését gátolhatják. Az ígéretes biológiai hatást hordozó 13a-ösztron származékok előállítása számos szerves kémiai kihívást is rejt. A $13 \alpha$-epimer flexibilisebb vázzal rendelkezik, mint természetes megfelelője. Ezért gyakran az ösztronhoz képest eltérő kemo-, regio- és sztereoszelektivitással reagál. Kutatócsoportunk közel húszéves

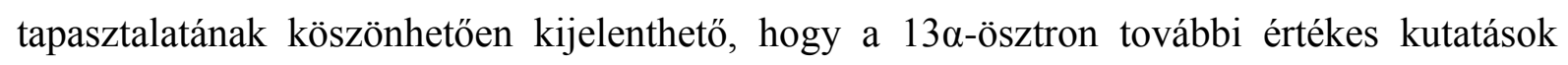
alapját képezheti a megváltozott gyürükonformációjának köszönhető érdekes kémiai és biológiai viselkedése alapján. Új területet nyithat meg az A-gyürüben módosított 13epimerek tanulmányozása, ugyanis ilyen származékok csupán elvétve találhatók a szakirodalomban. Kutatómunkánkban különös figyelmet fordítunk az A-gyürü módosításaira. A szakirodalom tanulmányozása során számos példát láttunk biológiailag értékes, Agyürüben szubsztituált természetes ösztron származékokra. Ezen vegyületeknél azonban a hatást általában ösztrogén aktivitás is kíséri. Jelen kutatás ezen a ponton is újdonságot hozhat, ugyanis az epimer vegyületnél ez utóbbi nagymértékben visszaszorul. Különösen érdekeltek bennünket az aromás gyürü olyan átalakítási lehetőségei, amelyek nem hagyományos, fenol rendszeren jól müködő aromás elektrofil szubsztitúciók, hanem nukleofil reakciópartnerekkel való reakciók, többek között C-C vagy C-N kötések kialakítása. Ilyen típusú átalakításokra lehetőséget kínálnak az utóbbi néhány évtizedben felfedezett, átmenetifém-katalizált keresztkapcsolási eljárások. Kemoszelektivitásuknak köszönhetően széles szubsztrátum körben alkalmazhatók, potenciális farmakofórok és heterociklusok előállítására is. Alkalmazhatóságukat tovább növeli, hogy mikrohullámú energiaközlés segítségével gyakran a hagyományos úton nem lejátszódó reakciók is megvalósíthatóvá válnak. Ezzel a technikával a reakcióidők akár nagyságrendileg is csökkenthetők és bizonyos esetben még oldószermentes közegben is kivitelezhetők. Munkánk során azt is bemutatjuk, hogy a kisebb, 
egy-vagy kétgyürüs vegyületekre kidolgozott katalitikus módszerek nem minden esetben vihetők át nagyobb biomolekulákra. Gyakran komoly optimalizálás és a körülmények jelentős megváltoztatása szükséges az eljárás sikeres kiterjesztéséhez.

Kutatásunk utolsó szakaszában egy másik területre is kitekintünk. Mivel szerves kémiai munkánk szorosan összefügg a biokémiai vizsgálatokkal, célunk volt olyan új szintetikus ösztron származékok előállítása is, amelyek hozzájárulhatnak az elavult, környezetre ártalmas biokémiai eljárások modernizálásához. A potenciális enzimgátlóknak a fent említett enzimekhez mutatott affinitásának vizsgálatára széles körben elterjedtek az in vitro radioszubsztrát inkubációs módszerek. Ezen eljárások általában az enzim radioaktívan jelzett szubsztrátjának alkalmazásával vizsgálják a tesztvegyületnek enzimreakcióra mutatott befolyását. Napjainkban a biokémiában és a molekuláris biológiában is egyre inkább előtérbe kerülnek a környezetre kevésbé ártalmas eljárások, amelyek a zöld kémia elveit is figyelembe veszik. Ilyenek többek között a fluoreszcensen jelölt vegyületek alkalmazásán alapuló módszerek. A szteroidok biokémiájában fontos előrelépést jelenthetne olyan vizsgálati módszerek kidolgozása, amelyek nem radioaktívan, hanem fluoreszcensen jelölt szteroidokon alapulnak. A fluoreszcens jelzőanyagok általában többgyürüs vegyületek. Ezeknek a szteroid adott pontjához való konjugálása nemcsak biokémiai, hanem szerves kémiai szempontból is nagy kihívást jelent. A konjugálás helye, a két molekularészletet összekötő kapcsoló elem (linker) hosszúsága, valamit a kapcsoló szerkezeti elem kémiai minősége meghatározó lehet a vegyület biológiai viselkedése szempontjából. 


\section{Irodalmi előzmények}

\subsection{Kémiai előzmények}

\subsubsection{Halogénezés}

Az ösztrán váz A-gyürüjének jódozására már 1911-es hivatkozás is található a szakirodalomban. $^{20}$ Több kutatócsoport is megvalósította a reakciót, különböző reakciókörülmények alkalmazásával, eltérö összetételü termékelegyhez jutva (3. ábra). A 2jód $(7(\mathrm{H}))$ és 4-jód $(\mathbf{8}(\mathrm{H}))$ regioizomerek mellett megfigyelték a 2,4-bisz származék (9) képződését is. Az ösztron jódozása lehetőséget adott radioaktívan jelölt hormon származékok előállítására is. Albert és munkatársai ${ }^{131} \mathrm{I}$-dal radiojelölt és jelöletlen, ún. „hideg” szubsztrátot állítottak elő azzal a céllal, hogy vizsgálják az ösztradiol $(3(\mathrm{H}, \mathrm{H}))$ szövetek szerinti eloszlását. ${ }^{21}$ A jódozási reakció regioszelektív megvalósítása szerves kémiai szempontból kihívást jelentett az aromás A-gyürü aktivált jellege miatt. Először Hillmann és munkatársai nyertek 2-jód-ösztront $\left(\mathbf{7}(\mathrm{H})^{\star}\right)$ regioszelektíven, higany(II)-jodid reagens alkalmazásával. ${ }^{22} \mathrm{~A}$ módszer előnye a regioszelektivitásban, hátránya viszont a reagens mérgező jellegében rejlik.
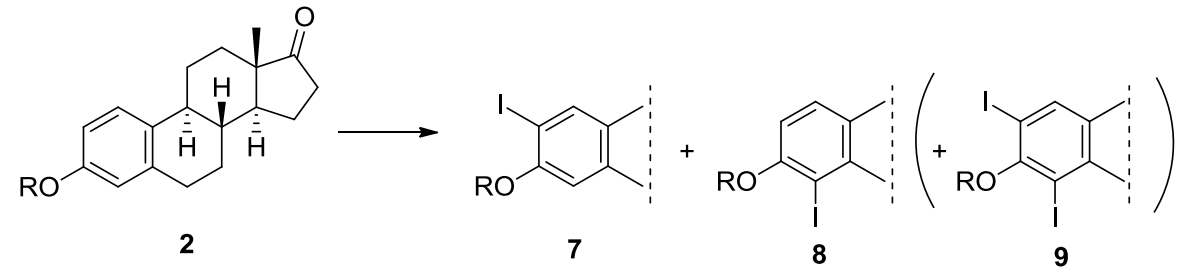

$\mathrm{R}=\mathrm{H}, \mathrm{Me}, \mathrm{Bn}, \mathrm{Ac}$

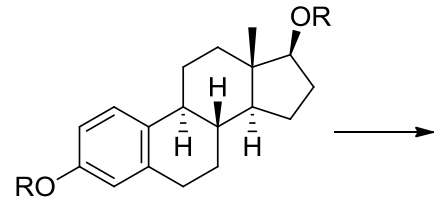

3<smiles>[R20]c1cc(I)c(I)cc1I</smiles>

10<smiles>[R20]c1ccc(I)c(I)c1I</smiles>

11

12

3. ábra Az ösztron (2) és 17ß-ösztradiol (3) A gyürüben jódozott származékai

Az egészségre ártalmas higany(II)-vegyületek alkalmazásának elkerülése érdekében Numazawa és munkatársai más módszer kidolgozására törekedtek: a 2,4-bisz-jód vegyületek $(\mathbf{9}(\mathrm{H}), \mathbf{1 2}(\mathrm{H}))$ dehalogénezésével állították elő a monoszubsztituált 2- és 4-regioizomerek keverékét (7(H) és 8(H), $\mathbf{1 0}(\mathrm{H})$ és 11 $(\mathrm{H})$ ) (4. Ábra, i., ii.). ${ }^{23}$

\footnotetext{
• A vegyületszámozásnál az R szubsztituenst zárójelben jelöljük
} 


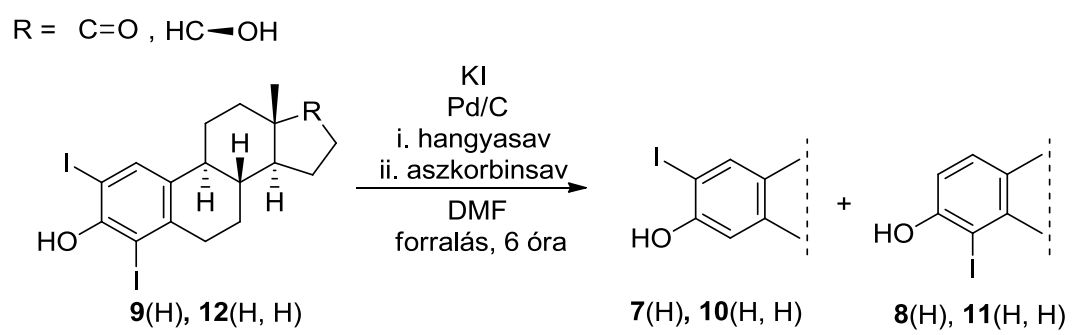

4. ábra A 2,4-bisz-jód-ösztron $(\mathbf{9}(\mathrm{H}))$ és -17ß-ösztradiol (12(H)) hidrodehalogénezése

Tomson és Horwitz egy másik szintézis útvonalon valósították meg az ösztron 3metiléterének (2(Me)) különböző halogénekkel való 2-es és 4-es helyzetü szubsztitúcióját (5. ábra). A többlépéses eljárás a fenolos A-gyürü $o$-helyzetben történő nitrálásával indul. A két $o$-nitro-regioizomer elválasztását követően kialakították a 3-metiléter védőcsoportot, majd a nitrocsoportokat aminocsoportokká redukálták. Az így nyert anilin származékokat diazotálásnak vetették alá, amely folyamatok során a megfelelő halogenid A-gyürübe való beépítésével többféle célvegyületet is előállítottak (17-22). Ez a reakciósor jól alkalmazható a két regioizomer halogénszármazék előállítására, azonban hosszadalmas, és az egyes részlépéseket követő tisztítási eljárások miatt jelentősen lecsökken a hozam. ${ }^{24}$

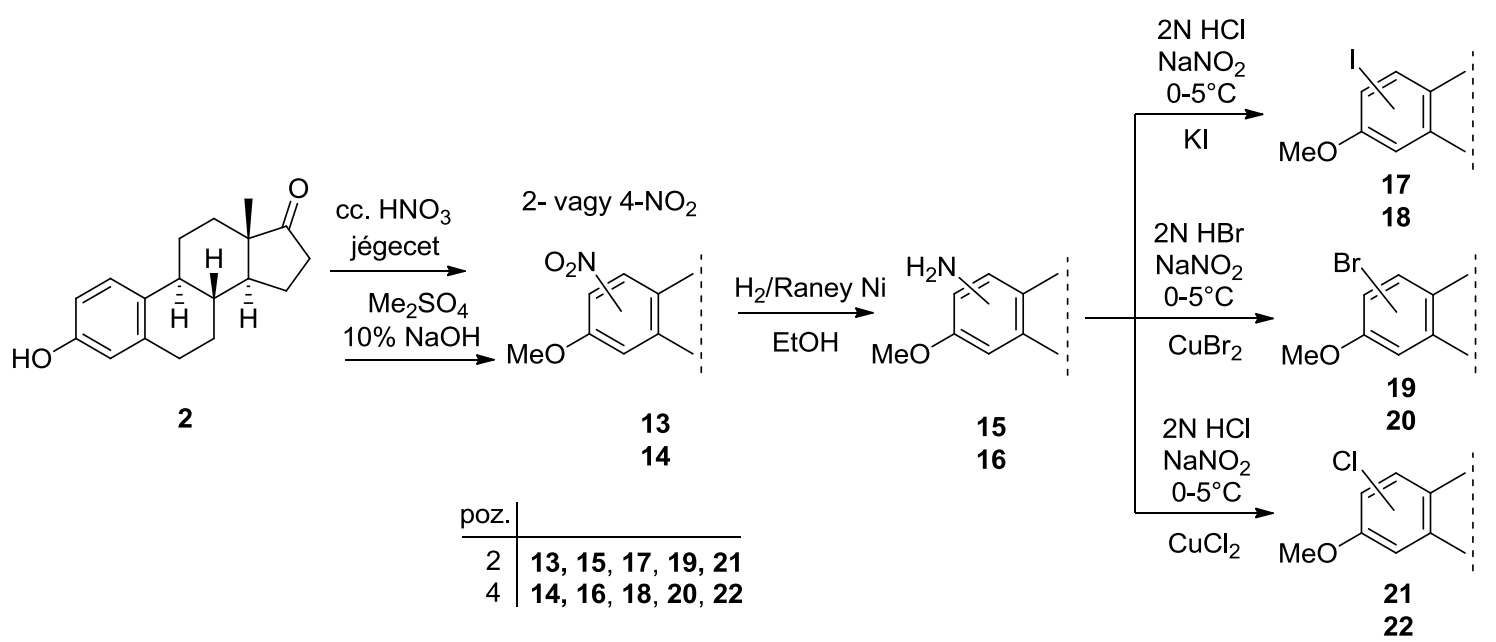

5. ábra A-gyürüben halogénezett származékok előállítása az ösztron 3-metiléteréből (2(Me))

1987-ben egy új regioszelektív jódozási módszert dolgoztak ki Lier és munkatársai. Az eljárás során ösztron-3-acetátot (2(Ac)) és ösztradiol-diacetátot (3(Ac, Ac)) jódoztak tallium(III)trifluoracetát aktiváló reagenst alkalmazva, amely során fötermékként a 2-szubsztituált származékokat nyerték (6. ábra). ${ }^{25} \mathrm{~A}$ tallium(III)-trifluoracetát (TTFA) trifluoracetilcsoportjainak elektronszívó hatása a tallium elektrofilitását jelentős mértékben növeli, ezért az készségesen reagál aromás szénhidrogénekkel. Ilyenkor aromás elektrofil szubsztitúciós 
reakcióban a megfelelő tallium-bisz(trifluoracetil)-származékok keletkeznek. Ez utóbbi vegyületek kálium vagy nátrium-jodiddal reagálatva regioszelektíven szolgáltatják a 2jódösztronokat. Az eljárás hátránya, hogy a vegyületben található szabad hidroxilcsoportok jelenléte oxidációs mellékreakciók kialakulásához vezet ${ }^{26}$, tehát védőcsoport kialakítását igényli. A 3-metiléter védőcsoport beépítése azonban megakadályozza a reakció lejátszódását. A kutatók megfigyelték továbbá, hogy az ösztron-3-acetátból (2(Ac)) 5:1 arányban a 2-es és 4-es regioizomerek, míg ösztradiol-3,17-diacetátból (3(Ac, Ac)) kizárólag a 2-es izomer képződött. A D-gyürűhöz kapcsolódó távoli funkciós csoport befolyása a kémiai viselkedésre a gyürürendszeren keresztüli hatással magyarázható (long range effect), ami a legtöbb ösztron származék esetében megfigyelhető. ${ }^{27,28}$

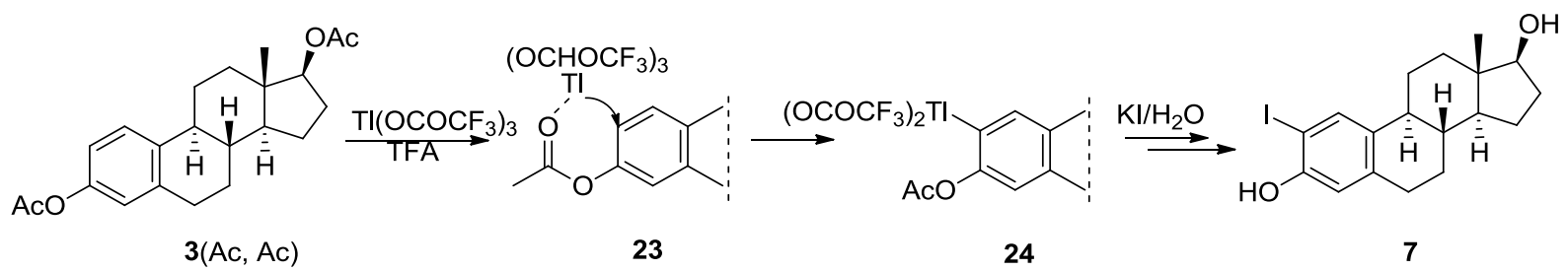

6. ábra Regioszelektív jódozás az ösztron aromás A-gyürüjében

A fenti módszert Bulman Page és munkatársai továbbfejlesztették réz sók alkalmazásával. ${ }^{29}$ Az ösztradiol-diacetát tallium(III) komplexét (24) réz(I)- vagy réz(II)-halogeniddel dioxánban forralták, majd dezacetileztést követően magas hozammal nyertek 2-halo származékokat. Azt tapasztalták, hogy réz(II)-halogenidekkel jobb hozamok ( $80 \%$ feletti) érhetők el, mint réz(I)sók alkalmazásával (50-60\%). Az eljárás kiterjeszthető különböző ellenionokra is, ezáltal többféle halogén szubsztituens is beépíthető ezzel a módszerrel. A kutatók feltételezése szerint a nagyfokú regioszelektivitásra egy hattagú kelátgyürünek a 3-as helyzetű acetát funkcióval való képződése adhat magyarázatot, amely kelátkomplex a nagy térkitöltése miatt inkább a 2-es helyzetủ talliummal alakul ki, mint a 4-es, térgátolt pozícióban. Ez a módszer tehát alkalmas lehet halogéneknek az ösztron A-gyürüjébe való regioszelektív beépítésére, azonban a tallium vegyületeinek gyógyszeripari felhasználásánál nagy hátrányt jelent azok mérgező hatása ${ }^{30}$ és magas ára.

Colobert és munkatársai a közelmúltban kidolgoztak egy enyhe körülményeket igénylő regioszelektív jódozási módszert $N$-jódszukcinimiddel (NIS), katalitikus mennyiségü trifluorecetsav (TFA) jelenlétében. (7. ábra) Kismolekulás, elektronban gazdag aromás rendszereket sikerült ily módon hatékonyan átalakítaniuk. Az általuk feltételezett mechanizmus szerint az in situ képződő jód-trifluoracetát igen reaktív elektrofilként 
viselkedik, ezáltal már szobahőmérsékleten is lehetővé teszi a jódozási reakciók gyors lejátszódását. ${ }^{31}$

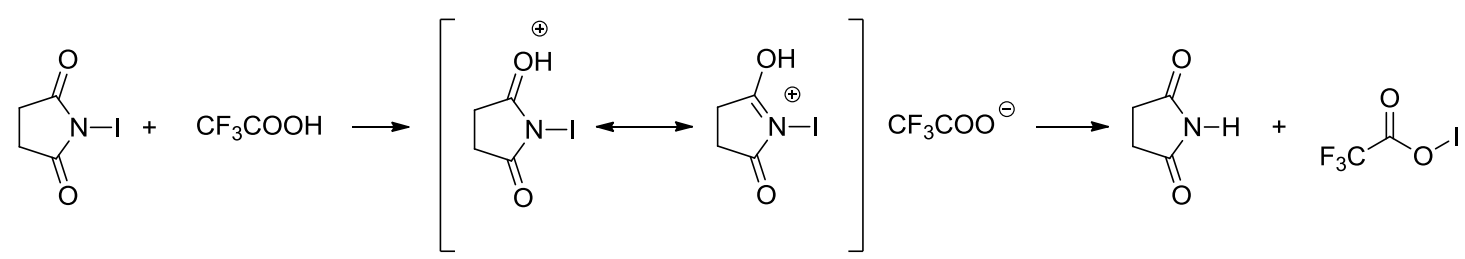

7. ábra A közitermék feltételezett képződése NIS-ből és TFA-ból.

A közelmúltban orosz kutatók indolvázas alkaloidok szelektív jódozására alkalmaztak a fentihez hasonló módszert, a TFA-t nem katalitikus mennyiségben, hanem oldószerként használva. ${ }^{32}$ Ezeket a modellrendszereken sikeresen müködő módszereket érdemes lehet összetett, nagyobb vegyületeken is tesztelni.

A jódozáshoz hasonlóan az ösztrán váz aromás gyürüjének brómozására is sok korai példa található az irodalomban. Különböző brómozó reagensek alkalmazásával több kutatócsoport is megvalósította, mely során különböző összetételü termékelegyeket nyertek. Az első irodalmi hivatkozás ösztrán vázas vegyületre 1940-ből származik Woodward-tól, amelyben 17 $\alpha$-ösztradiolból $(3(\mathrm{H}, \mathrm{H})) \quad N$-brómacetamiddal (NBA) nyert A-gyürüben szubsztituált vegyületeket. $^{33}$ Slaunwhite és Neely A-gyürüben szubsztituált ösztron és 17ß-ösztradiol származékokat (28-33) állítottak elő elemi bróm alkalmazásával vas katalizátor jelenlétében, illetve annak hiányában ecetsavas közegben. Ezzel párhuzamosan $N$-brómszukcinimiddel (NBS) kloroformban is végeztek brómozást (8. ábra, i., ii., iii.). ${ }^{34} \mathrm{Az}$ alkalmazott körülményektől függően monoszubsztituált 2- (28, 29) vagy 4-bróm (30, 31) származékokhoz, illetve 2,4-diszubsztituált vegyületekhez (32, 33) jutottak. Schwenk és munkatársai Woodward nyomán NBA-dal állították elő az ösztron és a 17ß-ösztradiol Agyürüben brómozott származékait. Ennek során a reagens mennyiségétől függően 4- és 2,4bisz-vegyületeket $(\mathbf{3 2}, \mathbf{3 3})$ nyertek (8. ábra, iv.). ${ }^{35}$ 


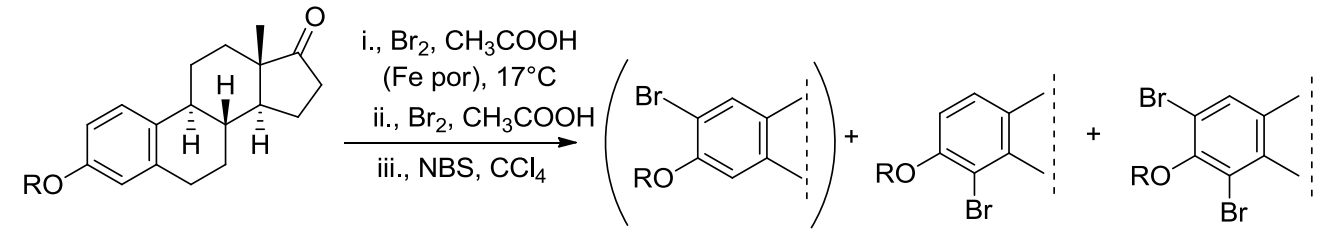

2

$\mathrm{R}=\mathrm{H}, \mathrm{Me}, \mathrm{Bn}, \mathrm{Ac}$
30<smiles>[R9]c1ccc(I)c(I)c1Br</smiles>

31<smiles>[R9]c1c(Br)cc(I)c(I)c1Br</smiles>

33

8. ábra Ösztrán vázas vegyületek brómozása

Leese és munkatársai egy másik útvonalon köztitermékként 2-bróm származékot (28) állítottak elö. ${ }^{36}$ Végső céljuk 2-es helyzetben szubsztituált ösztron-3-szulfamát (EMATE) analógok szintézise volt (9. ábra). A halogénezési reakció előtt a 3-as helyzetben metoximetil (MOM), a 17-es helyzetben pedig ketál védőcsoportot építettek be, ami két további reakciólépést jelentett. Az így nyert vegyület ígéretes biológiai hatást mutatott.

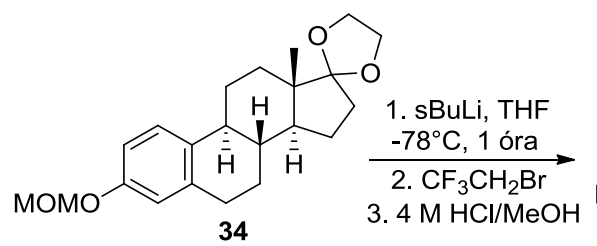<smiles>Oc1cc(I)c(I)cc1I</smiles>

28

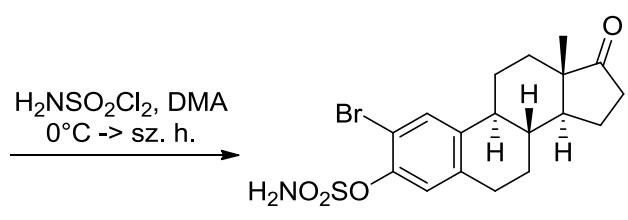

35

9. ábra Ösztrán vázas vegyület (34) brómozása

Aaron és munkatársai a közelmúltban egyszerü, enyhe körülményeket igénylő módszert dolgoztak ki. ${ }^{37}$ Az ösztront (2) kloroformban finomra őrölt NBS-del reagáltatták. A reakció gyorsan, kevesebb, mint 5 perc alatt végbement. A céljuk ösztron dimerek előállítása volt, amelyhez az így nyert halogénezett származékok előanyagként szolgáltak. A módszer hátránya azonban, hogy a kloroform alkalmazása annak egészségügyi kockázata miatt kerülendő. Numazawa és munkatársai ösztrogénekből $(\mathbf{2}(\mathrm{H}),(\mathbf{3}(\mathrm{H}))$ kiindulva $N, N$ dimetilformamidban (DMF) NBS vagy NIS feleslegében állítottak elő 2,4-diszubsztituált vegyületeket. Ezekből katalitikus dehidrogénezési lépés után Na-metiláttal metanolban DMF vagy piridin jelenlében halogén-metoxi cserereakcióban regiospecifikusan nyerték a 2- vagy 4-metoxi származékokat. ${ }^{38}$ 
Ösztrán vázas vegyület A-gyürüjének klórozását először a 17ß-ösztradiol 17-acetátjából $(\mathbf{3}(\mathrm{H}, \mathrm{Ac}))$ végezték. ${ }^{39}$ Mukawa triklórizocianursavval reagáltattta a szteroidot, és két

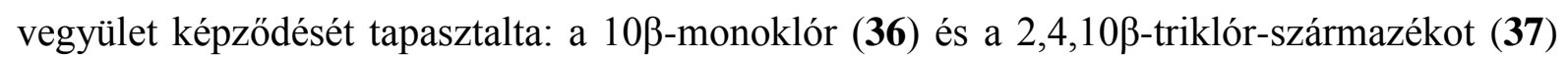
(10. ábra). Az alkalmazott reakciókörülmény hatására a fenolos hidroxilcsoporthoz képest orto vagy para helyzetbe lépett be a klór. Ezzel nagyjából egy időben Mills és munkatársai egy másik módszerrel acetonitrilben $\left(\mathrm{CH}_{3} \mathrm{CN}\right)$, NIS-del végeztek hasonló jellegű klórozást. ${ }^{40}$

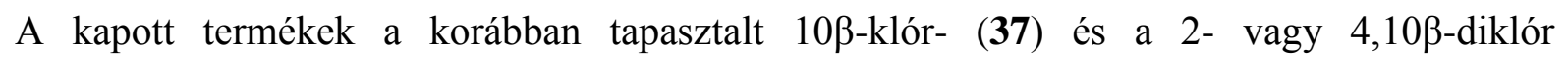
származékok $(38,39)$ voltak (10. ábra). A 10. ábrán feltüntetett eljárások hátránya, hogy az A-gyürü aromás jellege megszünt.
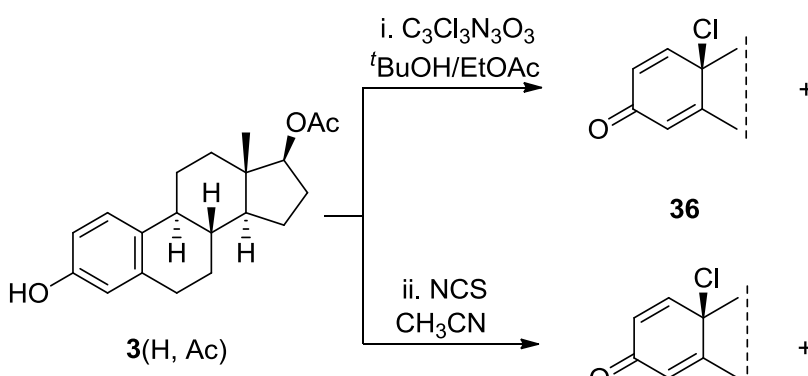<smiles>O=C1C(Cl)=CC(I)(I)C1I</smiles><smiles></smiles>

36<smiles>O=C1C=C(I)C(Cl)(I)C=C1Cl</smiles>

38<smiles>CC1=C(Cl)C(=O)C=CC1(C)Cl</smiles>

39

10. ábra Direkt klórozás Mukawa és Mills módszerével

Schwenk kutatócsoportja az ösztradiol 17ß-acetátjátból (3(H, Ac)) szulfonil-kloriddal, kloroformban valósították meg a klór bevitelét az aromás A-gyürübe. Ezzel a módszerrel először sikerült a 4-klórösztront (41) direkt klórozási módszer eredményeként izolálniuk (11. ábra). ${ }^{35}$ A módszerük szerint az A-gyürü aromássága megmarad azonban a szulfonil klorid igen erélyes reagens és körülményes a használata.

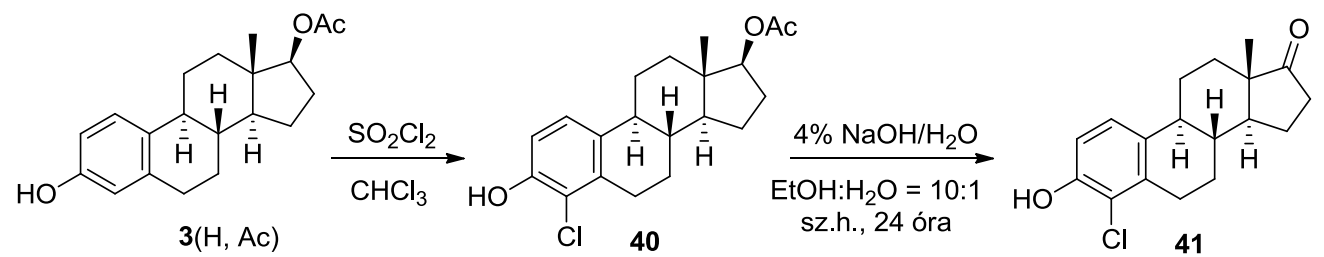

11. ábra Ösztron klórozása Schwenk módszerével

2-Klórösztront regioszelektíven a jódozásnál már ismertetett módszerrel, tallium komplexen keresztül réz(II)-kloriddal állítottak elő. ${ }^{29}$ 
Mindezek alapján kitünik, hogy az ösztrán vázas vegyületek aromás A-gyürüjének halogénezésére az irodalomban eddig szereplő módszerek általában többlépéses eljárások, amelyek gyakran toxikus reagensek alkalmazását igénylik. A folyamatok kemo- és regioszelektivitása a körülmények helyes megválasztásával befolyásolható, de csak bizonyos mértékig irányítható. A halogénezett ösztron származékok szerves és gyógyszerkémiai szempontból is értékesek. Alkalmas intermedierei lehetnek átmenetifém-katalizált keresztkapcsolási reakcióknak. Nemcsak a halogénvegyületek, hanem azok származékai is értékes biológiai aktivitást hordozhatnak. Mindezek miatt kulcsfontosságú lenne olyan halogénezési módszerek kidolgozása, amelyek egy lépésben, enyhe körülmények között és hatékonyan szolgáltatják a kívánt származékokat. 


\subsubsection{Sonogashira keresztkapcsolás szteroid modellen}

Napjainkban az átmenetifémek által katalizált keresztkapcsolási reakciók nagy jelentőséget kapnak a szerves szintézisekben, mivel lehetőséget nyújtanak új szerves vegyületek előállítására, hatékony és egyszerü módszerekkel. Keresztkapcsolási reakciókban új szénszén vagy szén-heteroatom közötti kötést kialakítása valósítható meg, általában enyhe reakciókörülmények között, gyorsan és szelektíven. A palládium (Pd) katalizátor alkalmazása a legelterjedtebb, ugyanis alkalmas ligandumokkal jól hangolható, és változatos szerkezetű reaktánsokat tolerál. Az előző fejezetben is tárgyalt aril-halogenidek megfelelő katalizátor választással alkénekkel Heck, organosztannátokkal Stille, aril- vagy alkil-boronsavakkal Suzuki, terminális alkinekkel pedig Sonogashira kapcsolási reakcióba vihetők. A Sonogashira kapcsolást széleskörüen alkalmazzák terminális acetilének és aril- vagy vinil-halogenidek közötti (C)sp-(C)sp $p^{2}$ kötés kialakítására. Ilyen típusú szénatomok közötti új kötés kialakítására több eljárás is található az irodalomban. Végrehajtható sztöchiometrikus mennyiségben hozzáadott alkinil-fém reagensekkel (acetilének magnézium-, cink-, ón- vagy bórszármazékaival. ${ }^{41}$ A Sonogashira-Hagihara típusú kapcsolás során a réz segédkatalizátor jelenlétében az acetilénből in situ képződik annak reaktív rézszármazéka, amely elősegíti a reakció lejátszódását. ${ }^{42}$

A Sonogashira kapcsolás feltételezett általános mechanizmusát a 12. ábra mutatja be. A pontos mechanizmus nem teljesen tisztázott, feltételezések szerint függhet akár a $\mathrm{Pd} /$ ligandum/szubsztrát kombinációtól is. ${ }^{43}$ A reakcióban a $(0)$ oxidációs állapotú fém a katalizátor aktív formája. Ez elérhető a megfelelő vegyületének alkalmazásával vagy képződhet in situ a Pd prekatalizátor +2-es oxidációs állapotú sójából. A katalitikus ciklus első lépésében az elektrofil reagens oxidatív addícióval (I) a Pd-komplexre kerül, formálisan a Pd beékelődik a szén-halogén kötés közé. A folyamat elektronhiányos aril-halogenidekkel gyorsabban lejátszódik, a reaktivitás $\mathrm{I}>\mathrm{OTf}($ trifluormetán-szulfonát) $>\mathrm{Br}>\mathrm{Cl}$ sorrendben csökken. ${ }^{44}$ Ezt a lépést (I) tovább gyorsítja az aromás vegyületen elektronvonzó csoportok jelenléte, a poláris oldószerek, valamint az elektronban gazdag foszfán ligandumok alkalmazása. ${ }^{45-50}$ Ezt követően a katalitikus mennyiségű $\mathrm{Cu}(\mathrm{I})$-ion $\pi$-komplexet alakít ki az acetilén származékkal, ezáltal nő az acetilén savas karaktere, és az alkalmazott bázis hatására réz-acetilid alakul ki (II). A következö lépésben az acetilid transzmetallálódik (III) és egy ariletinil-palládium-komplex képződik. A transzmetallálás hajtóereje a két fém elektronegativitása közötti különbség $\left(\mathrm{EN}_{\mathrm{Cu}}<\mathrm{EN}_{\mathrm{Pd}}\right)$, ugyanis a transzmetalláló fémnek elektropozitívabbnak kell lennie a Pd-nál. ${ }^{51,52}$ A réz annál készségesebben veszi át a 
halogenidet, minél nagyobb a Pd-on az elektronsürüség. A transz-komplex cisz-komplexszé izomerizálódik (IV), amelyből reduktív eliminációval (V) képződik a kívánt acetilén származék. A körfolyamat végén a Pd ismét 0 oxidációs állapotba kerül, ez újabb kapcsolást tesz lehetővé.

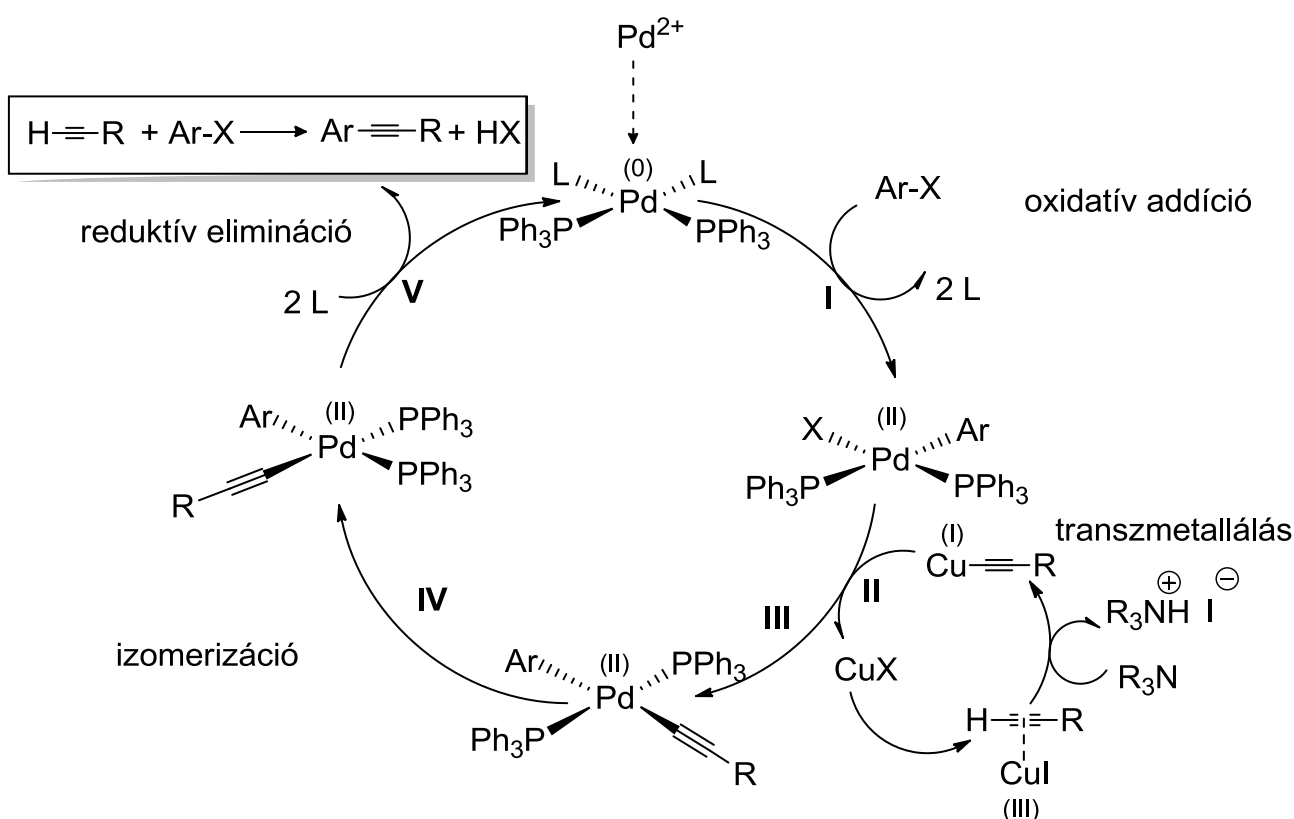

12. ábra A Sonogashira kapcsolás feltételezett mechanizmusa

Sonogashira kapcsolások során katalizátorforrásként gyakran 2-es oxidációs állapotú $\mathrm{PdCl}_{2}\left(\mathrm{PPh}_{3}\right)_{2}$-ot vagy $\mathrm{Pd}(\mathrm{OAc})_{2}$-ot használnak, mivel ezek levegőre és nedvességre kevésbé érzékenyek, valamint könnyen redukálhatók. (0) Oxidációs állapotban is bevihetjük a Pd-ot a rendszerbe $\mathrm{Pd}(\mathrm{dba})_{2}, \mathrm{Pd}_{2}(\mathrm{dba})_{3}$ vagy $\mathrm{Pd}\left(\mathrm{PPh}_{3}\right)_{4}$ komplexek formájában, de ezek sokkal érzékenyebbek a nedvességre és a levegőre. A ligandumoknak jelentős hatásuk van a katalizátor aktivitására, ugyanis befolyásolják a komplex stabilitását, szerkezetét és elektronsürüségét. A nagy térkitöltésü ligandumok gyorsítják az oxidatív addíciót és a reduktív eliminációt. A foszfán $\left(\mathrm{PR}_{3}\right)$ alapú ligandumok bizonyultak leghatékonyabbnak (13. ábra). Ezekkel gyorsabban és enyhébb körülmények között hajtható végre a kapcsolás. A foszfor elektronküldő szubsztituensei azáltal, hogy növelik az átmenetifém elektronsürüségét stabilabb komplexet eredményeznek, illetve a transzmetallálási lépést (II) is elősegítik. ${ }^{53}$ 


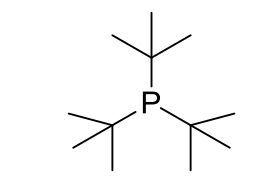

tri-terc.-butil-foszfán<smiles>Pc1ccc2ccccc2c1-c1c(P)ccc2ccccc12</smiles>

BINAP

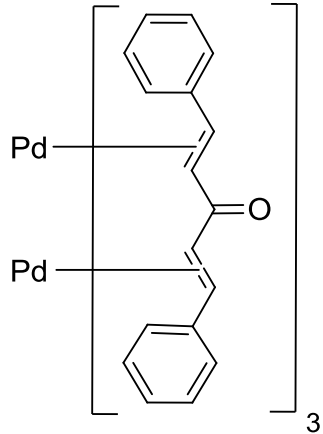

$\mathrm{Pd}_{2} \mathrm{dba}_{3}$

13. ábra Foszfán ligandumok és egy (0) oxidációs állapotú Pd katalizátor $\left(\mathrm{Pd}_{2} \mathrm{dba}_{3}\right)$

Szteránvázas vegyületeken, többek között ösztrán vázon is végeztek már Sonogashira kapcsolást, föként a D-gyürün. Ez utóbbi esetben a szteroid alkinként szerepelt, és azt reagáltatták különböző aril-halogenidekkel. 17 $\alpha$-Etinil ösztradiolból kiindulva (42) többféle keresztkapcsolási reakciót is végeztek különböző fémkomplexekkel (14. ábra), ahol a képződő konjugátum (45) antitumor hatásáról is beszámoltak. ${ }^{54-56}$

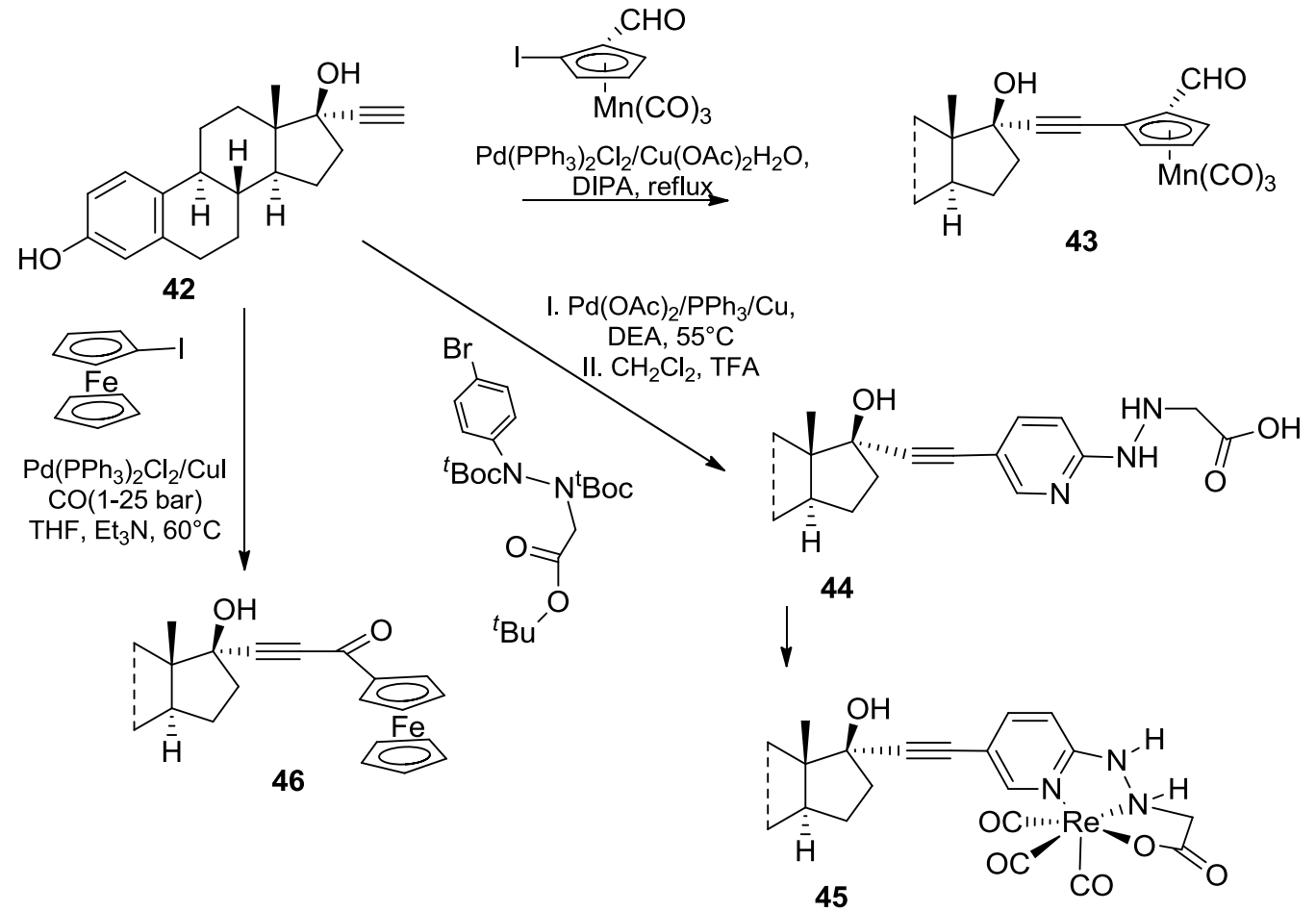

14. ábra 17 $\alpha$-Etinil-ösztradiol származékok szintézise Sonogashira kapcsolással

Az ösztron A-gyürüjén Möller és munkatársai végeztek csupán Sonogashira kapcsolást, a szteroidot aril-halogenidként alkalmazva (15. ábra). Kiindulási anyagként 3-acetoxi-2jódvegyületet (47) használtak, reagensként fenil-acetilént alkalmaztak, $\operatorname{Pd}(\mathrm{OAc})_{2}$ katalizátor 
és CuI segédkatalizátor jelenlétében. A fenetinil közti származék (48) jelentős 17ß-HSD1 inhibitor aktivitást mutatott. ${ }^{57}$ A kapott vegyületből a 2-fenetil származékot (49) teljes telítéssel nyerték. Nem végeztek reakciókat szubsztituált fenil-acetilénekkel, és nem valósították meg az etinilcsoport részleges telítését sem. Az ösztrán váz 4-es szénatomján jelen munka kezdetéig nem ismeretes Sonogashira kapcsolás.

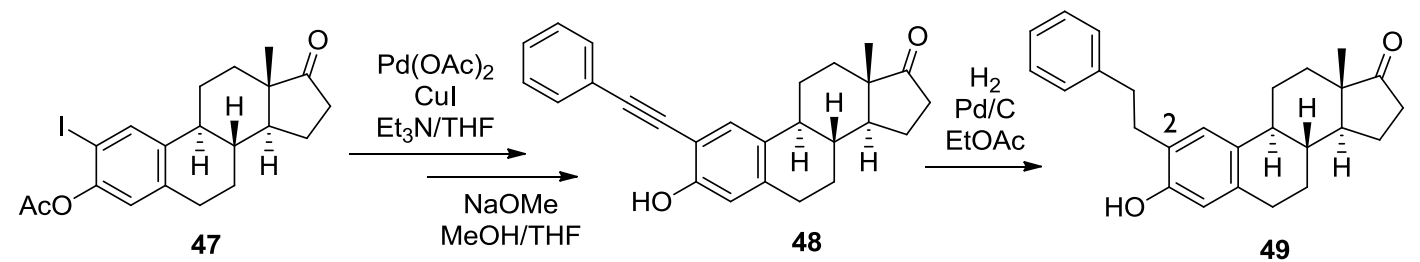

15. ábra Sonogashira kapcsolás ösztron halogenidből (47) kiindulva

A mikrohullámú besugárzás alkalmazása az elmúlt évtizedben nagy népszerüségre tett szert. Mikrohullámmal a kémiai átalakítások széles skáláján sikerült növelni a reakciósebességet és emelni a katalitikus ciklusfrekvenciát (turnover frequency, TOF). ${ }^{58}$ Alkalmazása az átmenetifém katalizált keresztkapcsolási reakciókban is gyorsan teret hódított. ${ }^{59}$ Kabalka és munkatársai ismertettek először mikrohullámú technikával segített Sonogashira keresztkapcsolást. $^{60}$ Változatos szerkezetű aromás, heteroaromás és vinil-jodidokat kapcsoltak terminális acetilénekkel oldószermentes közegben. A reakció szilárd alumíniumoxid hordozón elemi Pd katalizátor, CuI ko-katalizátor és $\mathrm{PPh}_{3}$ ligandum jelenlétében, mikrohullámú reaktorban igen rövid idő alatt végbement (2,5 perc, 100W). Aril-bromidok és kloridok átalakítására nem volt alkalmas a módszer. Katalizátorok vagy ligandum hiányában nem történt reakció és a hordozó is nélkülözhetetlen volt a mellékreakciók elkerülésének érdekében. Homogén közegü Sonogashira reakcióra mikrohullámú melegítési módszert Erdély és Gogoll dolgozott ki. ${ }^{61}$ A kutatók speciális vastag falú reakcióedényben kapcsoltak aromás és heteroaromás halogenideket és triflátokat trimetilszilil-acetilénnel (TMSA) DMF oldószerben jó-kiváló hozammal. A reakcióhoz $\mathrm{Pd}$ sót, $\mathrm{PdCl}_{2}\left(\mathrm{PPh}_{3}\right)_{2}-\mathrm{t}$ alkalmaztak katalizátorként és dietilamin (DEA) bázist. A mikrohullámú besugárzással 20-100-szoros reakciósebesség növekedést tudtak elérni. 


\subsubsection{Stilbén és benzofurán alapváz elöállitása Pd katalizált keresztkapcsolási reakciókban}

Számos biológiailag aktív természetes eredetű vegyület tartalmaz stilbén (1,2-diariletilén) alapvázat. ${ }^{62,63}$ A cisz-stilbén alapváz a 16. ábra bal oldalán látható, a jobb oldalon pedig egy analóg szerkezetü kombresztatin A-4 foszfát (50), amely tumorellenes szerként a klinikai kivizsgálás kísérleti III. fázisában tartó hatóanyag. ${ }^{64}$ Ismeretesek az irodalomban olyan ösztránvázas kombresztatin analógok is, melyek cisz izomerei antiproliferatívnak bizonyultak ösztrogén receptor pozitív, 17ßHSD1 enzimet expresszáló tumoros emlő sejtvonalon (MCF7) és tripla negatív (ER, PR és HER2) MDA-MB-231 sejteken is, míg transz párjaik hatástalanok voltak. ${ }^{65}$<smiles>C=Cc1ccccc1</smiles>

cisz-stilbén<smiles>COc1ccc(/C=C/c2cc(OC)c(OC)c(OC)c2)cc1OP(=O)(O)O</smiles>

50

16. ábra Balra: cisz-stilbén alapváz, Jobbra: kombresztatin A-4 (50)

A gyógyszerkémiai kutatásokban külön kihívást jelent az olyan katalitikus módszerek kidolgozása, amellyel farmakológiailag aktív cisz-stilbének szintézise hatékonyan és szelektíven végrehajtható. Erre lehetőséget nyújt a láncközi alkinek cisz-alkénekké való sztereoszelektív részleges hidrogénezése. A részleges telítés kétféle katalitikus módszerrel érhető el: Lindlar-katalizátorral, molekuláris hidrogént alkalmazva ${ }^{66,67}$ vagy hidrogén donorokkal történő transzfer hidrogénezéssel. ${ }^{68,69} \mathrm{Az}$ utóbbi módszer alkalmazása olyan előnyökkel jár, mint a biztonságosabb megvalósíthatóság és a kemoszelektivitás jobb irányíthatósága. Poláris kettős kötést, (például oxovegyületek, iminek) tartalmazó vegyületek transzfer hidrogénezésére számos irodalmi hivatkozás található ${ }^{70-74}$ azonban láncközi alkinek ily módon történő részleges telítésére csak elvétve találunk példát a szakirodalomban. ${ }^{75-79}$ Elsevier és munkatársa hidrogén donorként $\mathrm{HCOOH} / \mathrm{Et}_{3} \mathrm{~N}-\mathrm{t}$ alkalmazott palládium- $\mathrm{N}$ heterociklusos karbén katalizátor jelenlétében. Egyes általuk vizsgált alkinek azonban alacsony kemoszelektivitással szolgáltatták a cisz-alkén célvegyületeket, ezekben az esetekben teljes telítés is lejátszódott. ${ }^{69}$ Egy kínai kutatócsoport, Li és munkatársai katalizátorként $\mathrm{Pd}(\mathrm{OAc})_{2}$ vagy $\mathrm{Pd}\left(\mathrm{PPh}_{3}\right) \mathrm{Cl}_{2}$-t, valamint másik hidrogénforrást, $\mathrm{DMF} / \mathrm{KOH}$ elegyet alkalmaztak a $\mathrm{HCOOH}$ in situ elöállítására. ${ }^{80}$ A két katalizátor közül a $\mathrm{Pd}(\mathrm{OAc})_{2}$ 
hagyományos melegítés mellett magasabb hozammal és jobb kemo- és sztereoszelektivitással szolgáltatta a kívánt cisz-alkéneket. A 17. ábrán látható az alkinek Pd-katalizált részleges telítésének feltételezett mechanizmusa. ${ }^{80} \mathrm{Az}$ in situ előállított (I) HCOOH oxidatív addícióval (II) a Pd-ra (0) kerül, majd az alkin beékelődésével (III) kapjuk a $\mathbf{C}$ intermediert. Az ezt követő dekarboxilezéssel (IV) és reduktív eliminációval $(\mathbf{V})$ nyerjük a cisz-alként ${ }^{80}$. A kutatóknak tehát sikerült egy hatékony és szelektív transzfer hidrogénezési eljárást kidolgozniuk cisz-stilbének előállítására, azonban a módszert csak kismolekulás rendszereken vizsgálták. A reakciók lejátszódásához hosszú, 6-9 órás reakcióidőkre volt szükség.

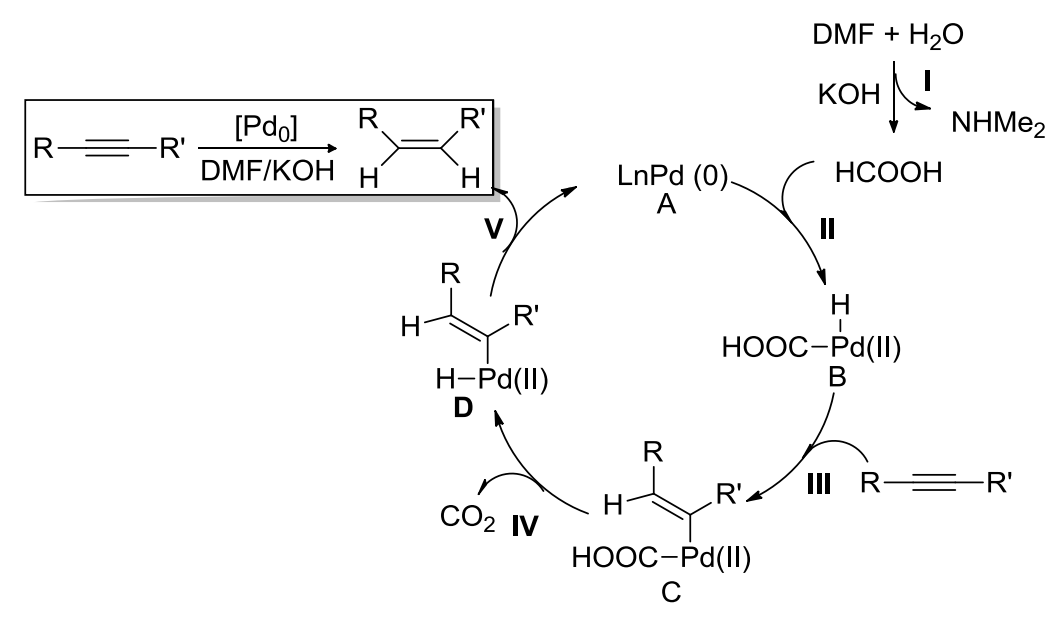

17. ábra Alkinek Pd-katalizált részleges telítésének feltételezett mechanizmusa

A stilbénnek nemcsak a cisz, hanem különféle transz-származékai is értékes biológiai aktivitást hordoznak. Ebbe a vegyületcsoportba tartozik a rezveratrol (3,5,4'-trihidroxistilbén) (51a), amely egy a természetben számos növényben előforduló polifenol. A vegyület egészségre gyakorolt jótékony hatása már rég óta ismeretes. Többek között tumorellenes hatással is rendelkezik. A modern vizsgálati módszereknek köszönhetően kiderült, hogy a rezveratrol a tumorsejtekben apoptózist indukál ${ }^{81}$, antiangiogén ${ }^{82}$ hatású és egyes redoxi folyamatokban részt vevő enzimek mRNS transzkripcióját is modulálja ${ }^{83-86}$ A közelmúltban kitünt, hogy a teljesen metilezett származéka (51b) in vitro fokozottabb tumorellenes aktivitást mutat, mint polifenol megfelelője (18. ábra). ${ }^{87,88}$

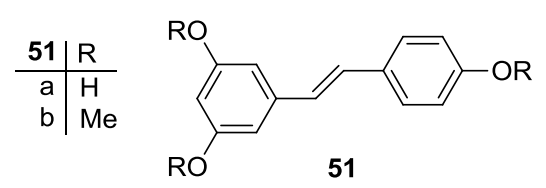

18. ábra A rezveratrol (51a) és a metilezett származékának (51b) szerkezete 
Egy másik fontos alapváz a biomolekulák körében a benzofurán, amely benzolból és furánból származtatható kondenzált vázas heterociklusos vegyület. Ez a heterociklus számos a természetben előforduló biomolekula alapját képezi. A benzofurán váznak tulajdonítható jelentős biológiai aktivitás miatt a kutatók számos szintetikus származékot is előállítottak, amelyek szerteágazó biológiai aktivitással rendelkeznek. Ezek között ismeretesek antitumor hatásúak is. ${ }^{89,90}$ A benzofurán alapváz kialakítására számos szintetikus eljárás ismert az irodalomban, kulcslépésként elsősorban Hoesch- vagy Wittig-reakciót, illetve Pd-katalizált keresztkapcsolást alkalmazva. ${ }^{91}$ Szubsztituált benzofuránok előállítására egyre elterjedtebben alkalmazzák a Sonogashira keresztkapcsolást, például gyógyszerhatóanyagok szintézisénél. ${ }^{92}$ Goussu és Villemin oldotta meg elsőként benzofuránok Pd-katalizált szintézisét. ${ }^{93}$ Kiindulási anyagként 2-brómfenolt alkalmaztak, trietilamin $\left(\mathrm{Et}_{3} \mathrm{~N}\right)$ oldószer, $\mathrm{PdCl}_{2}\left(\mathrm{PPh}_{3}\right)_{2}$ és $\mathrm{CuI}$ katalizátorok jelenlétében. A vignafurán (56) totálszintézisét Sakamoto Pd-katalizált és gyürűzárási reakcióval végezte el (19. ábra). ${ }^{94}$ A gyürürendszer kialakításához $o$-helyzetben nukleofil sajátságú szubsztituenst tartalmazó aril-halogenid (52) szükséges. A keresztkapcsolást követően, a hozzáadott bázis hatására a nukleofil támadása az acetilénen gyürüzárást eredményez, amit a Pd katalizátorhoz történő koordináció elősegíthet.<smiles>C#Cc1ccc(O[Sb])cc1OC</smiles>

19. ábra Vignafurán (56) előállítása Sonogashira keresztkapcsolást követő gyürüzárással

Mindezek alapján elmondható, hogy a stilbén vagy benzofenon molekularészletet hordozó vegyületek gyógyszerkémiai szempontból ígéretesek lehetnek. Külön érdeklődésre tarthatnak számot azon szintetikus hibridmolekulák, amelyek a fenti alapvázaknak más bioaktív természetes eredetű vegyületekkel való konjugálásával képződnek. 


\subsubsection{Buchwald Hartwig kapcsolás}

Az arilhalogenidek keresztkapcsolási reakcióit napjainkban elterjedten alkalmazzák szén-szén kötés kialakítására. A Buchwald és Hartwig által felfedezett Pd katalizálta reakcióban (B-H kapcsolás) azonban lehetőség nyílik szén-nitrogén kötés kialakítására is. ${ }^{95,96} \mathrm{Az}$ arilhalogenidekből hagyományos, aromás nukleofil szubsztitúcióval előállítható vegyületek száma meglehetősen korlátozott, mivel a nem aktivált aromás halogenidek reakcióba viteléhez erélyes körülményekre és magas hőmérsékletre van szükség. A hagyományos módszereket felválthatják az átmenetifém-katalizált keresztkapcsolási reakciók, amelyek enyhébb körülmények között is megvalósíthatók, és így a korábban irányítási vagy elektronikus problémák miatt nem elérhető származékok is könnyen előállíthatóvá váltak (20. Ábra). A BH kapcsolás segítségével leggyakrabban aromás aminokat vagy bioaktív heterociklusos vegyületeket állítanak elő nagy hatékonysággal.

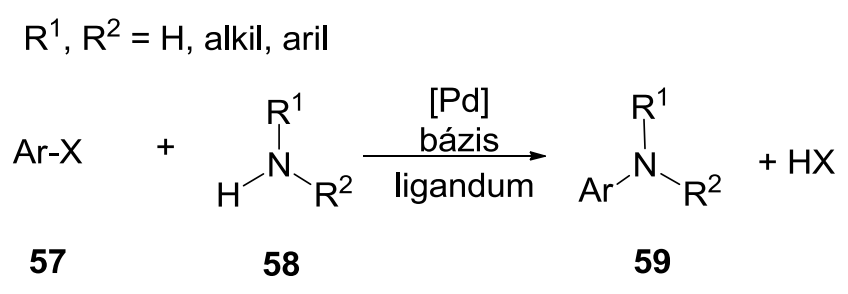

20. ábra Általános Buchwald-Hartwig reakció

A 21. ábrán a B-H kapcsolás feltételezett mechanizmusának egy sémája látható egy arilhalogenid (57) és egy alifás amin (58) között. A katalitikus ciklusban az elemi lépések sorrendjére különböző elképzelések is léteznek. Így Buchwald és Blackmond javaslata alapján először vagy a Pd oxidatív addíciója (I) játszódik le, vagy az amin asszociációja (II). ${ }^{97} \mathrm{Ez}$ utóbbit támasztja alá a reakciósebesség függése az amin koncentrációjától. Szintén emellett az út mellett szól, hogy ha a katalizátort előzőleg aminnal kevertették, akkor a kevertetés időtartamának növelésével a reaktánsok hozzáadását követően a kapcsolás sebessége növekedett. A következő lépésben (III) az amin deprotonálódása történik, azonban nem tisztázott, hogy a bázis kilöki az $\mathrm{X}^{-}$távozócsoportot vagy a telített koordinációs szférából közvetlenül a komplexen deprotonálja az amint. 


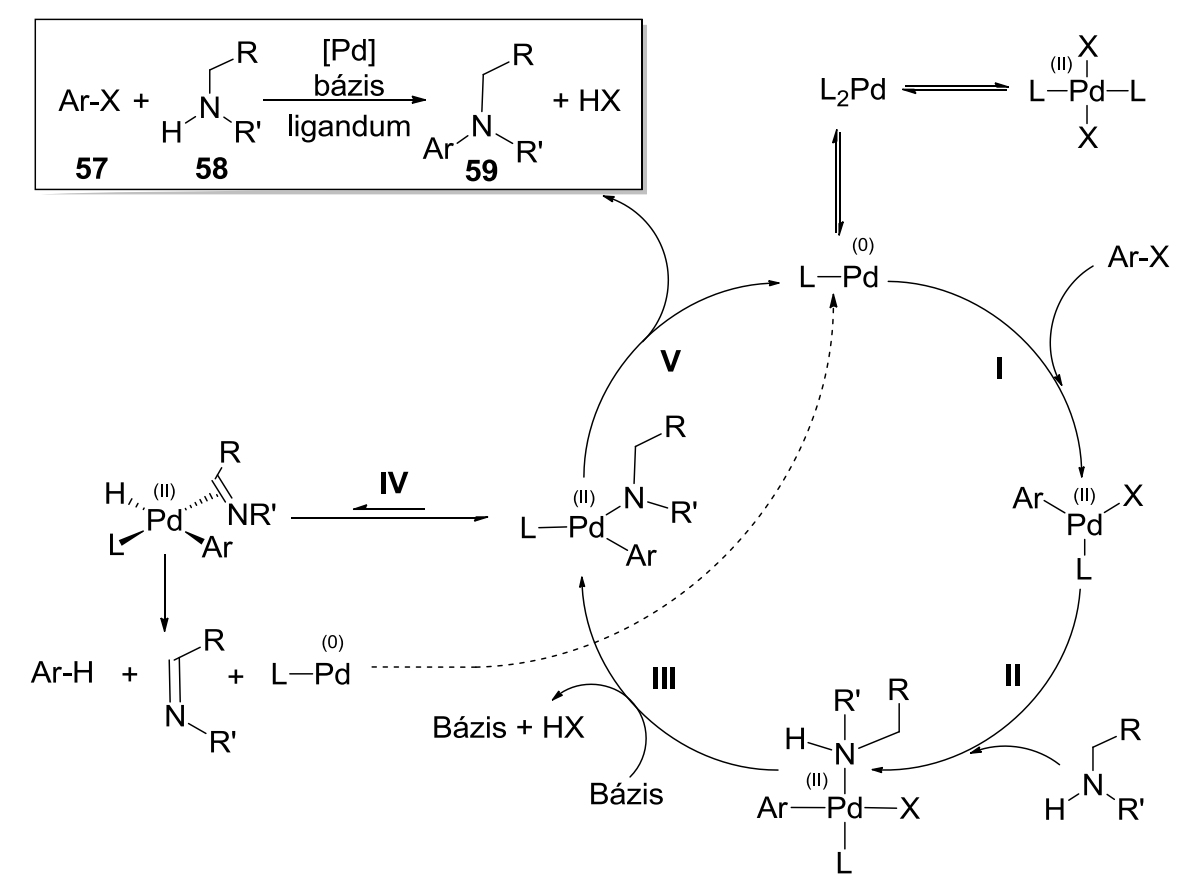

21. ábra A Buchwald-Hartwig reakció feltételezett mechanizmusa ${ }^{97}$

A reakció sikerességét, hozamát nagyban befolyásolják a katalitikus körfolyamatban résztvevő komponenesek kémiai tulajdonságai, valamint a bázis, a ligandum, a katalizátor forrás és a reakciópartnerek szerkezete is. Tekintve, hogy reakció kimenetelét illetően mindegyik lényeges szempont, ezért ezeket részletesen tárgyaljuk.

Svéd és angol kutatók a bázis pontos szerepének tisztázására elméleti kémiai számításokat végeztek. ${ }^{98} \mathrm{~A}$ szervetlen bázisok közül elterjedten alkalmazzák a $\mathrm{Cs}_{2} \mathrm{CO}_{3}$-ot gyenge bázisként, míg a $\mathrm{KO}^{t} \mathrm{Bu}$ és a $\mathrm{NaO}^{t} \mathrm{Bu}$ erős bázicitásuk és jó elektronikus tulajdonságaik miatt népszerüek. Utóbbiak esetében azonban a reakció során képződő $\mathrm{KBr}$ vagy $\mathrm{NaBr}$ kevéssé oldódik szerves oldószerekben, ez pedig gátat szab az áramlásos reaktorban való alkalmazhatóságuknak. Ennek kiküszöbölésére kísérleteket végeztek szerves bázisokkal is, mint pl. a DBU-val, amellyel anilinek mikrohullámú átalakítását valósították meg sikeresen. ${ }^{99}$

Az aril-halogenidek szerkezete lényegesen befolyásolja a reduktív elimináció sebességét. Kapcsolópartnerként alkalmazhatók a hagyományosan felhasznált ariljodidok, -bromidok, kloridok és -triflátok, újabban tozilátok is. A reduktív eliminációs lépés (V) tanulmányozása során Hartwig és Driver úgy találták, hogy a sebességét egyáltalán nem befolyásolta, ha trifenil-foszfánt $\left(\mathrm{PPh}_{3}\right)$ adagoltak különböző mennyiségben a rendszerbe. Ebből arra lehet következtetni, hogy a reduktív eliminációt nem előzi meg ligandum disszociációja, hanem 
közvetlenül a tetrakoordinált komplexen látszódik le. A reduktív elimináció sebességét gyorsította, ha az aril-halogenid aromás gyürüje elektronhiányos volt. ${ }^{100}$

A B-H kapcsoláshoz a Sonogashira kapcsolásnál már tárgyalt $\operatorname{Pd}(\mathrm{II})$ és $\operatorname{Pd}(0)$ katalizátor források használatosak stabilitásuk és könnyü kezelhetőségük miatt. Ligandumként elsősorban szintén elektrongazdag foszfánokat (XPhos, DavePhos, SPhos) alkalmaznak, azonban ezek szerkezete gyakran jelentősen eltér a Sonogashira reakciónál használtaktól. A B-H reakciók segítő ligandumai általában biaril foszfán vegyületek, melyek komplexükben Pd-P és Pd-arén kölcsöhatást is mutatnak a, tehát bidentált jellegűek (22. ábra). A Pd a foszfort nem hordozó aromás gyürűhöz $\pi$-koordinációval kapcsolódik, ami elősegíti a reduktív eliminációs lépést $(\mathbf{V}) .^{101} \mathrm{Az}$ intermedier szerkezete röntgendiffrakciós mérések alapján bizonyított. ${ }^{102} \mathrm{~A}$ fentiekhez hasonló levegő és nedvesség türő tulajdonságokat mutatnak az $N$-heterociklusos karbének (NHC) Pd komplexei is, amelyek általában a kevéssé reaktív arilkloridok kapcsolási reakcióit segítik. (22. ábra). ${ }^{103,104}$ A BINAP ligandum Sonogashira és B-H kapcsolásban egyaránt gyakran alkalmazott. Elönyös tulajdonságai közé tartozik a szubsztrátumok széles körében való felhasználhatóság, ${ }^{105}$ akár királis aminok szintézisében is. ${ }^{106}$

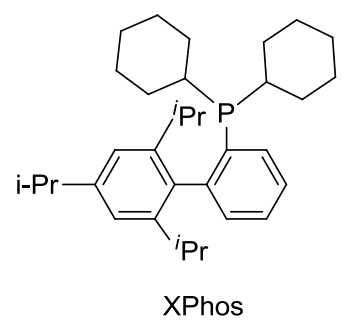

XPhos

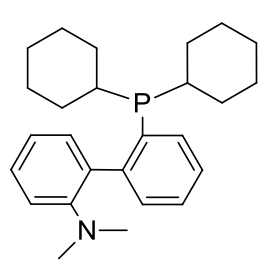

DavePhos

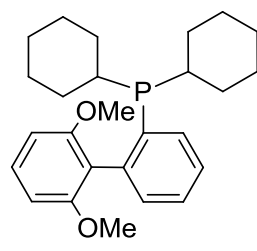

SPhos

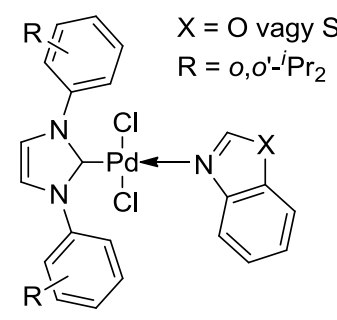

$N$-heterociklus karbén-Pd komplex

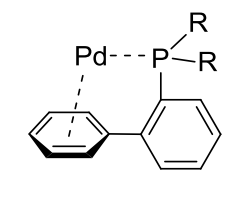

Pd koordinációja foszfán ligandumhoz

22. ábra Foszfán ligandumok és egy példa karbén gyorsító komplexre

A B-H reakció primer és szekunder aminokkal is lejátszódik, habár általában szükség van a reakciókörülmények gondos optimalizálására. A különféle típusú aminok kapcsolásában a következő reaktivitási sorrend figyelhető meg: aromás aminok > gyürüs szekunder aminok > aliciklusos szekunder aminok $>$ alifás primer aminok.

Mikrohullámmal segített B-H kapcsolásra a szakirodalomban csak elvétve és fóként kismolekulákra találunk példát. Singh és munkatársai végeztek erre irányuló kísérleteket. A reakció egy aromás (61) és egy telített heterociklusos aminnal (62) is $90 \%$ feletti hozammal játszódott le mikrohullámú reaktorban, 10 perc alatt. (23. ábra). Kitünt, hogy ugyanazon 
körülmények között a különbözőképpen szubsztituált aminok közel hasonló hozammal képződtek. ${ }^{107}$
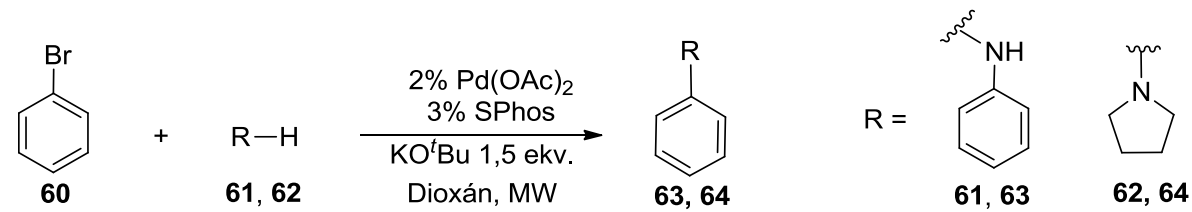

23. ábra Példa mikrohullámmal segített B-H kapcsolásra

Az anizolok B-H kapcsolási reakciót kiemelten tárgyaljuk, ugyanis mi is hasonló aromás rendszeren végezzük a kapcsolásokat. Az anizolok aromás gyürüje a metoxicsoport elektronküldő jellegének köszönhetően elektronban gazdag. A metoxicsoport jelenléte lassítja a brómanizolok reduktív eliminációs lépését. ${ }^{108,109} \mathrm{Az} o$-brómanizolok B-H kapcsolása szubsztituált, térgátolt anilinekkel lassú, szubsztituálatlan anilinnel pedig kifejezetten nehézkes, ezért olyan erős bázisok alkalmazását kívánja meg, mint például a $\mathrm{NaO}^{\mathrm{t}} \mathrm{Bu}$ vagy KO ${ }^{t} \mathrm{Bu}$. Az anilin o-helyzetü szubsztituneseinek jelenléte tehát előnyös a kapcsolás szempontjából. ${ }^{110-114}$ A $p$-brómanizol rosszabbul szerepelt anilinekkel való reakcióban, mint a brómbenzol vagy a $p$-brómtoluol. Az anilin orto helyzetü szubsztitúciója esetén azonban a szubsztituens méretének növelésével a hozam javuló tendenciát mutatott. Etil és izopropil szubsztituens esetében kiváló hozammal játszódott le a kapcsolási reakció. ${ }^{109,115}$ Az 24. ábrán látható ezeket összefoglalva a $o$-brómanizol és anilin példáján keresztül bemutatva egy feltételezett katalitikus körfolyamat. 


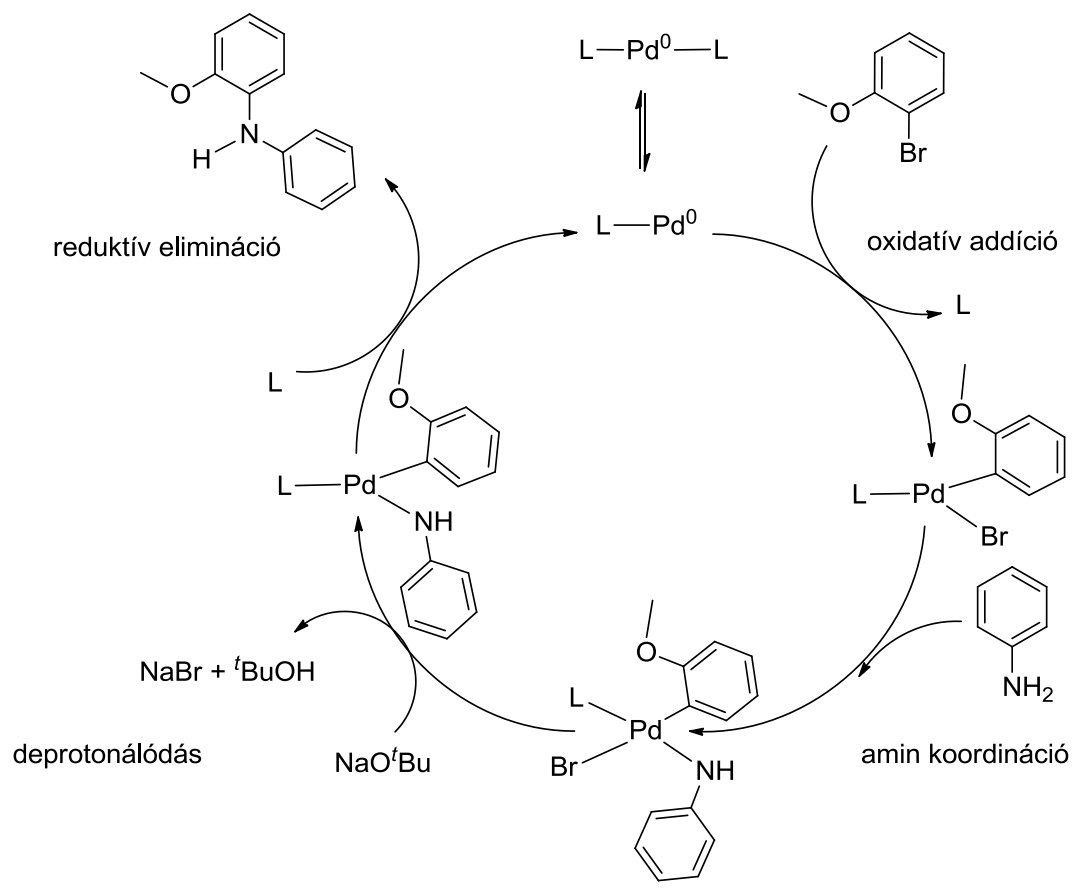

24. ábra Feltételezett reakciómechanizmus $o$-brómanizol és anilin példáján keresztül $\mathrm{NaO}^{t} \mathrm{Bu}$ bázissal

A természetes ösztron 2-es és 4-es helyzetü aminálását korábban klasszikus nitrálással majd azt követő redukcióval kétlépésben valósították meg (vö. 5. ábra). ${ }^{24}$ A 3-aminoösztron (67) előállítására a közelmúltban több módszert is ismertettek (25. ábra). Poirier és munkatársai hatékony Pd-katalizált keresztkapcsolási eljárást dolgoztak ki az ösztron-3-triflátból (2(Tf)) kiindulva, benzofenon-imint alkalmazva amin forrásként. ${ }^{116}$ és munkatársai ugyanezt a reakciót másik úton is megvalósították, mely során benzilamint alkalmaztak aminként. Ezen aminálási eljárások két lépésben szolgáltatták a kívánt terméket, mivel egy második lépésben, a hidrogenolízissel vagy savas hasítással nyerték a 3 -aminoösztront (67). ${ }^{117}$ Egy tavaly megjelent közleményben beszámolnak arról, hogy a 66-os vegyület nemcsak a fent említett módszerekkel alakítható aminná, hanem transzaminálással is. A 17-es ketocsoportot ketál védőcsoporttal látták el, majd a 3-amino származékot (67) hidroxilaminnal való reakcióban nyerték az iminből. ${ }^{118} \mathrm{Ez}$ az eljárás is többlépéses reakciósorban szolgáltatja a kívánt amino származékot. Nemcsak Pd-katalízissel, hanem egy speciálisan erre a célra elöállított $\mathrm{N}$ heterociklusos karbén nikkellel alkotott komplexének segítségével is előállították a 3aminoösztront ammóniával való reakcióban. ${ }^{119}$ A fentiekben említett eljárások hátránya egyrészt a reakciólépések számában, másrészt az olykor drága katalizátorok felhasználásában rejlik. 


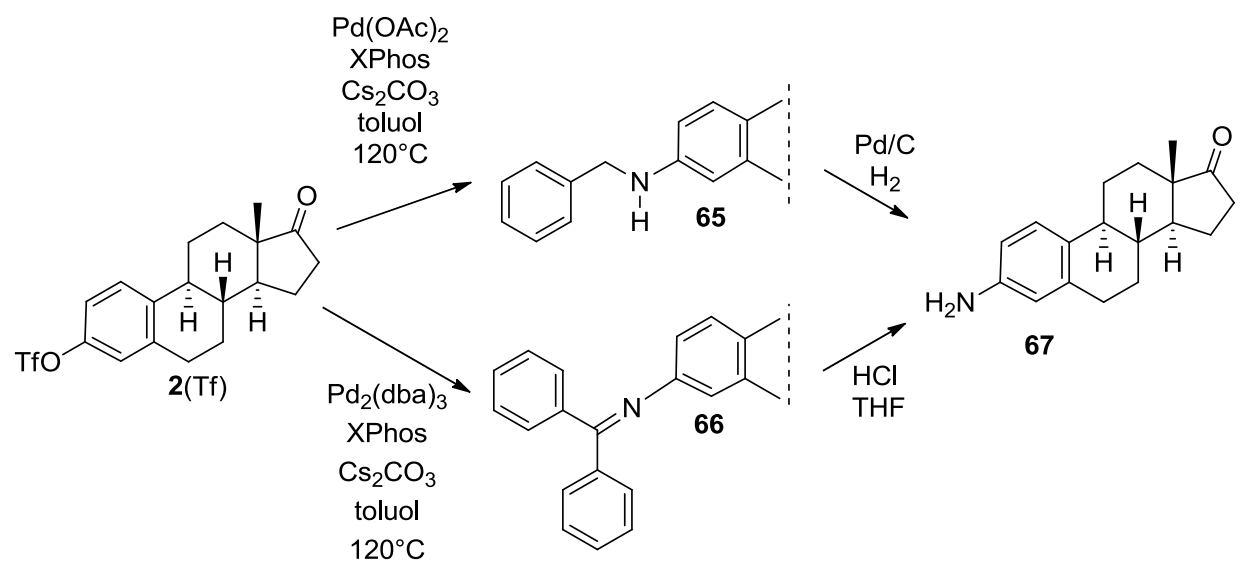

25. ábra A 3-aminoösztron (67) elöállítása

Összefoglalva a B-H aminálásal kapcsolatban ismertetett, ösztron sorban leírt módszereket, megállapítható, hogy a B-H aminálás alkalmas az ösztrán váz 3-as helyzetében való funkcionalizálásra, azonban a fenolos $\mathrm{OH}$-csoport melletti 2-es és 4-es szénatomokon még nem valósítottak meg ilyen reakciókat. Szerves kémiai és biológia szempontból is értékes lehet egy olyan Pd-katalizált eljárása kidolgozása, amely hatékonyan, egylépésben szolgáltatna szubsztituált aminocsoportot 2-es vagy 4-es helyzetben tartalmazó ösztron származékokat. 


\subsubsection{A BODIPY fluoreszcens festékek és ösztronnal képzett konjugátumaik}

A biokémiában és a molekuláris biológiában többféle fluoreszcens jelölőanyagot alkalmaznak. Napjainkban azonban a difluor-bórindacén család (BODIPY) tudhatja magáénak a legsokoldalúbb fluorofór elismerést, ugyanis ezek a festékek alkalmasak fehérjék vagy nukleinsavak jelölésére. 1968-ban Treibs és Kreuzer állították elő a vegyületcsalád első tagját. $^{120}$ A BODIPY-k igazi népszerüségét a festékek biológiai jelölésre való alkalmazhatósága hozta meg. A BODIPY a fluoreszcein fotostabil helyettesítőjeként vált ismertté a biokémikusok és biológusok között, miután néhány ilyen BODIPY alapú festéket sikerült jelölőanyagként értékesíteni a piacon. ${ }^{121} 21$. század elején számos szabadalmat nyújtottak be biológiai jelölési módszerekről. Ezzel párhuzamosan alapkutatások kezdődtek ezen festékek kémiai reaktivitását és optikai tulajdonságait tárgyalva. A BODIPY festékek az ultraibolya tartományban erősen abszorbeáló anyagok, amelyek viszonylag éles fluoreszcens csúcsokat emittálnak magas kvantumhatásfokkal. Nem érzékenyek környezetük polaritására és pH-jára, ezért viszonylag stabilisak fiziológiai körülmények között. Vázuk kémiailag könnyen módosítható, ezáltal befolyásolhatók az optikai jellemzőik is. A szubsztituensek növekvő számával az abszorbciós és emissziós maximumok vöröseltolódása figyelhető meg. Számos előnyt mutatnak a korábban használt fluoreszkáló festékekhez képest: éles abszorpciós sávok (25-35 nm), nagy moláris abszorpciós koefficiensek, hosszú szingletállapotú fluoreszcencia élettartamokkal, kiváló kémiai és fotokémiai stabilitás oldatban és szilárd állapotban egyaránt, jó oldhatóság számos oldószerben és aggregációval szembeni ellenálló képesség. ${ }^{122}$ A számos kedvező tulajdonságuk ellenére ezen festékek hátrányos jellemzőkkel is rendelkeznek, amelyek befolyásolják biotechnológiai alkalmazhatóságukat. A legtöbb vegyület $600 \mathrm{~nm}$ alatt emittál, és csupán néhány vízoldékony származék ismeretes. ${ }^{123}$ A 26. ábra mutatja a BODIPY alapváz IUPAC számozását és a gyakran használatos $\alpha$-, $\beta$ - és a mezo-pozíciók jelölését.

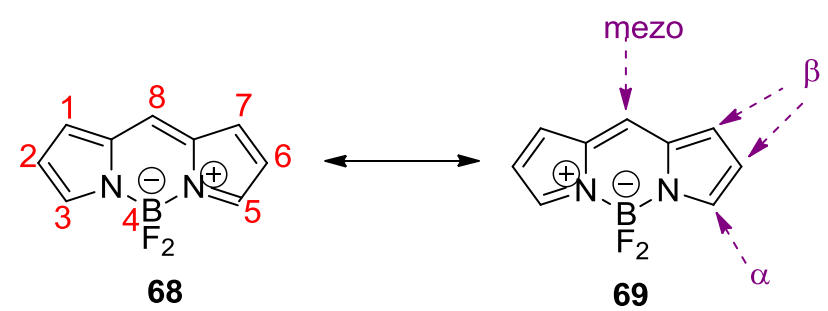

26. ábra A BODIPY festékek alapváza és IUPAC számozása. 
A mezo-helyzetben történő alkilezés vagy arilezés nincs különösebb hatással az elnyelési és kibocsátási hullámhosszakra (27. ábra). ${ }^{124}$ A mezo-helyzetű fenilcsoportot tartalmazó festékek esetében a kvantumhatásfok kisebb, mint a többszörösen szubsztituált fenilcsoportot hordozóké. Ezek a különbségek annak tudhatók be, hogy az 1,7-szubsztituensek megakadályozzák a fenilcsoport szabad forgását, ezáltal csökkentve a gerjesztett állapot sugárzásmentes úton, molekuláris mozgásokon keresztüli relaxációját. Ezzel összhangban, a fenil-gyürüre $o$-helyzetbe szubsztituenseket beépítve jelentősen növelhető a kvantumhatásfok. ${ }^{122}$

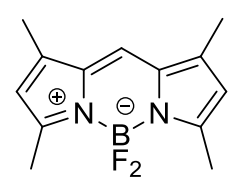

70

EtOH, $\Phi 0,80$

$\lambda_{\text {max absz }} 505 \mathrm{~nm}$

$\lambda_{\max \text { emissz }} 518 \mathrm{~nm}$

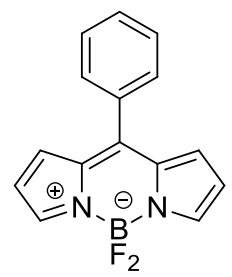

71

$\mathrm{MeOH}, \Phi 0,19$

$\lambda_{\max \text { absz }} 508 \mathrm{~nm}$

$\lambda_{\text {max emissz }} 521 \mathrm{~nm}$

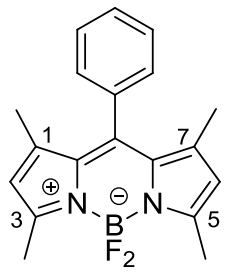

72

$\mathrm{MeOH}, \Phi 0,65$

$\lambda_{\text {max absz }} 498 \mathrm{~nm}$

$\lambda_{\text {max emissz }} 508 \mathrm{~nm}$

27. ábra Szubsztituálatlan (71) és 1,3,5,7-tetrametil-szubsztituált BODIPY számazékok (70,

72) fluoreszcens tulajdonságai

BODIPY festékek elöállítására több módszer ismeretes az irodalomban. Az egyik leggyakrabban alkalmazott eljárás szerint pirrolt (73) reagáltatnak savhalogeniddel, amely reakció során egy instabil dipirrometén hidroklorid só intermedier (74) keletkezik. A só stabilitása és izolálhatósága nagymértékben függ a pirrol szubsztituáltságától: minél kevesebb szubsztituenst tartalmaz a heterociklus, annál nehezebben kezelhető az intermedier. Mindezek miatt a sót általában izolálás nélkül alakítják tovább a kívánt céltermékké (75). Ez a módszer nem alkalmas a szubsztituálatlan pirrol heterociklus célzott átalakítására, ugyanis abból ilyen körülmények között többféle melléktermék is kialakulhat (28. ábra). A pirrol-savklorid kondenzációs stratégiának fontos előnye, hogy nem szükséges a savkloridból származó mezo helyzetü szénatomot külön lépésben oxidálni, így elkerülhetők az oxidatív körülmények hatására lejátszódó mellékreakciók.

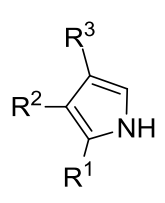

73

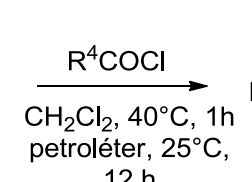

$12 \mathrm{~h}$

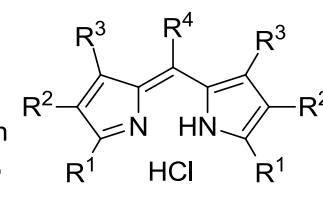

74

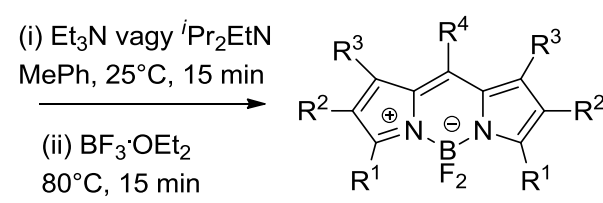

75

28. ábra BODIPY-festék előállításának sémája savhalogeniddel. 
A szubsztituálatlan pirrol átalakítására nem a savhalogeniddel, hanem az aldehiddel való kondenzáció javasolt. ${ }^{125}$ A 29 . ábra bemutatja a festék előállításának menetét pirrolból és aromás aldehidből (76) kiindulva. Az aldehidet szobahőmérsékleten nagy feleslegben alkalmazott pirrolban (a pirrolfelesleg alkalmazásával elkerülhető a nagy mennyiségü melléktermék képződés) oldják. A kialakult dipirrometán köztiterméket (77) izolálják, majd oxidálják és bórral komplexálják (78). Ezen eljárás hátránya, hogy a kialakuló dipirrometán intermediert a bórral való komplexálás előtt oxidálni kell. Az oxidálószerek alkalmazása azonban számos gyakorlati problémát vet fel, többek között a melléktermékektől való megtisztítás nehézségeit. Ezek elkerülése érdekében a tisztítást általában a komplexálás után valósítják meg. ${ }^{126}$

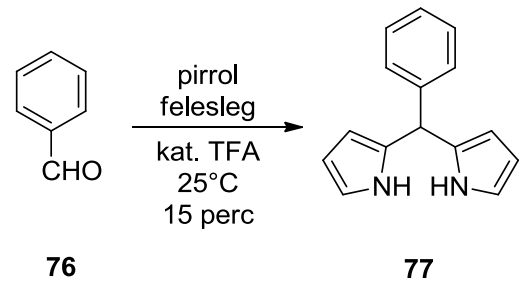

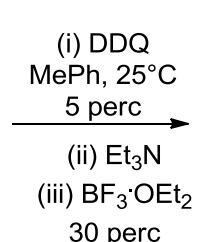

30 perc

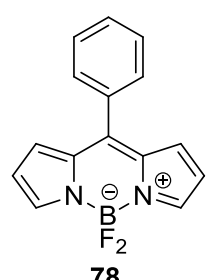

78

29. ábra BODIPY festék előállításának sémája aromás aldehidből.

Kevés ösztron-BODIPY konjugátum ismeretes a szakirodalomban ${ }^{122}$. Egy-két korai példát követően az utóbbi néhány évben újra előtérbe került ez a kutatási terület. A biomolekulák fluoreszcens jelölése kiegészíthetné, sőt egyes esetekben felválthatná a környezetre ártalmas radioizotópos jelölésen alapuló elavult módszereket. A nagyméretű fluoreszcens festékek biomolekulákhoz való kapcsolása azonban komoly szerves kémiai kihívásokat rejt, ugyanis a festék kiválasztásán túlmenően, annak kapcsolási helye és módja, továbbá a két molekularészlet közötti távolság mind meghatározó lehet a vegyület biológiai viselkedése szempontjából. A közelmúltban teret hódító átmenetifém-katalizált eljárások ezen a kutatási területen is megjelentek. A konjugáláshoz az utóbbi néhány évben réz(I) katalizált azid-alkin ciklodaddíciót (CuAAC) vagy Sonogashira reakciót alkalmaztak. A jelölés helyének kiválasztása biológiai okokra vezethető vissza, ennek tárgyalását és az eddig előállított ösztron-BODIPY konjugátumok biológiai viselkedését a biológiai előzményekben tárgyaljuk. Az ismert ösztron-BODIPY konjugátumok egy-két kivételtől eltekintve $7 \alpha$ - vagy $17 \alpha-$ helyzetben jelöltek. 
A szakirodalmat áttekintve két olyan eljárást ismertetünk, amely $7 \alpha$-helyzetben való jelölésen alapul. French és munkatársai egy öt szénatomos linkeren keresztül, savamid kötéssel kapcsolták össze a két molekularészletet (30. ábra). ${ }^{127}$ Az ösztron-amint in situ állították elő a 3-O-benzil védett előanyag azidból (79) és egy lépésben történő hidrogenolízis és redukciót követően a BODIPY-festék szukcinimidil-észterével $(\mathbf{8 0})$ reagáltatták.

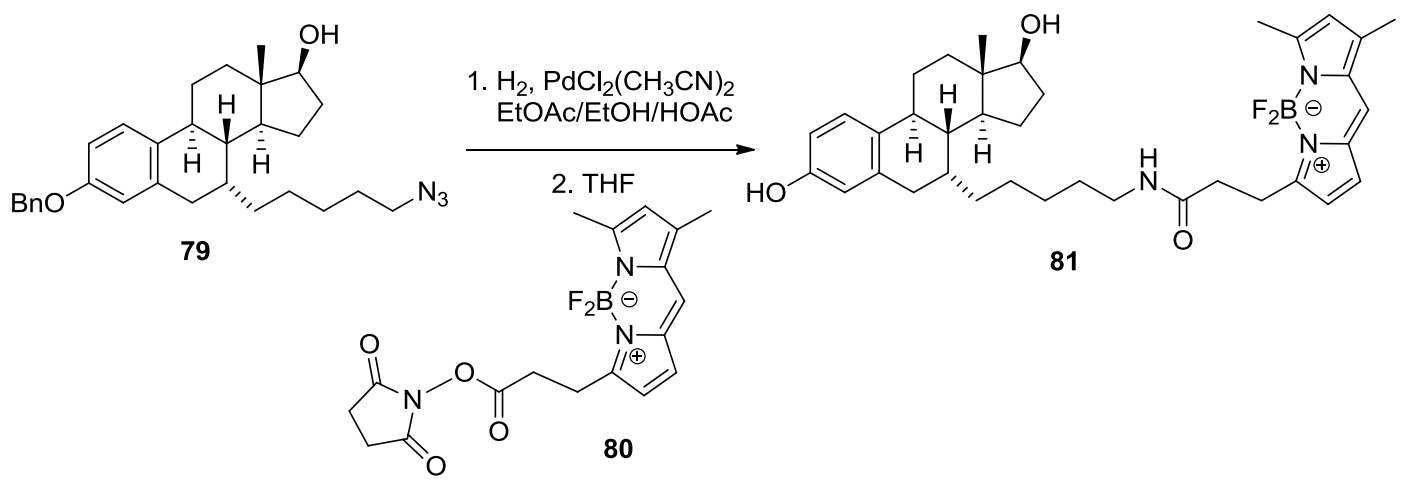

30. ábra 7a-pozícióban jelölt BODIPY-ösztradiol konjugátumok (81)

A másik 7a-pozícióban jelölt ösztradiol-BODIPY konjugátumot (85) olefin metatézissel állították elő, 7 $\alpha$-allil-ösztradiol (82) és 9-decenil-BODIPY (83) reakciójával (31. ábra). A reakcióhoz egy ruténium alapú, ú.n. második generációs Grubbs katalizátort (84) alkalmaztak. Ezzel az eljárással sikerült egy hosszú, 11 szénatomos távoltartó csoportot építeniük a szteroid és a festék közé. ${ }^{128}$

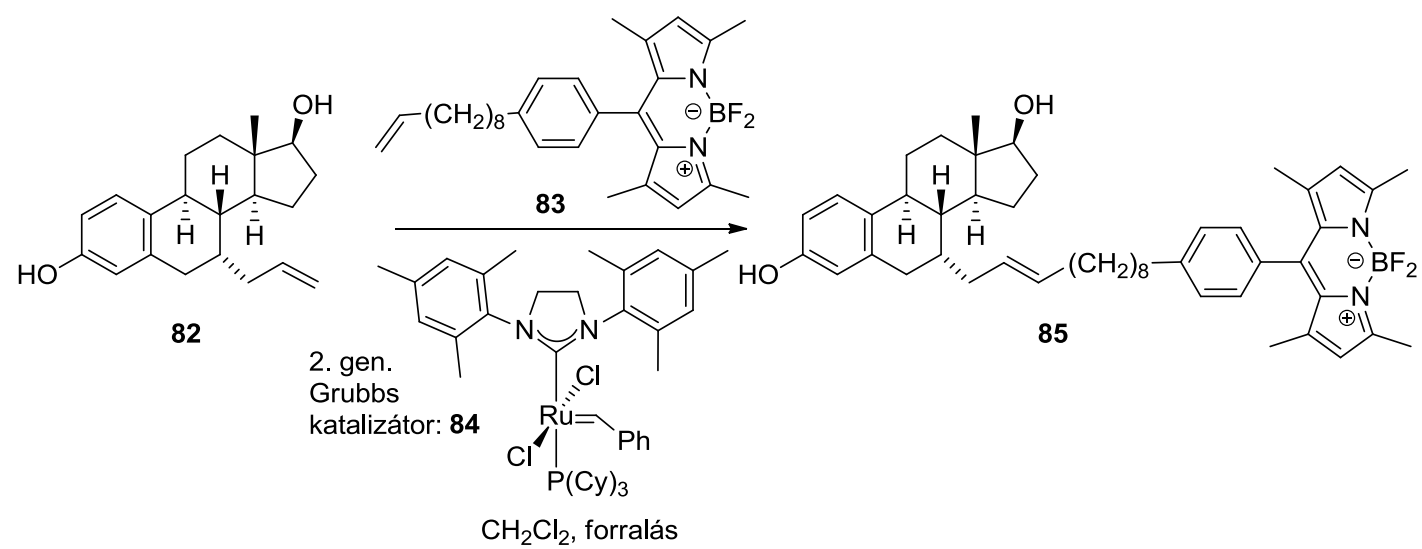

31. ábra 7a-pozícióban jelölt BODIPY-ösztradiol konjugátum (85)

Egy olyan munkát is érdemes kiemelni, amelyben az ösztront (2) a fenolos hidroxilcsoportján keresztül jelölték. Ennek csupán szerves kémiai érdekessége lehet, ugyanis a fluoreszcens jelölés a szteroid egyik fontos funkciós csoportját (3-OH) érinti, így jelentősen befolyásolhatja a jelölt vegyület biológiai viselkedését. A 8-metiltio-BODIPY-t (86) aromás 
nukleofil szubsztitúciós reakcióban kapcsolták a szteroidhoz, nátrium-karbonát bázis és $\mathrm{Cu}(\mathrm{I})$ tiofén-2-karboxilát jelenlétében (32. ábra). Azt feltételezték, hogy a $\mathrm{Cu}(\mathrm{I})$-ionok a metiltio csoport cserélődési reakcióját segítik elő azáltal, hogy koordinálódnak a kénhez, ezzel gyengítve a C-S kötést. ${ }^{124}$

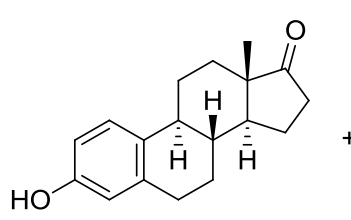

2

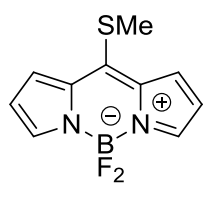

86

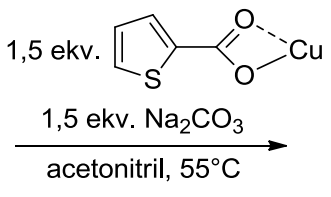

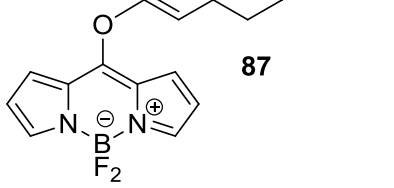

32. ábra Az ösztron (1) 8-metiltio-BODIPY-vel (34) való reakciójának sémája

Az utóbbi néhány évben átmenetifém-katalizált Sonogashira kapcsolással vagy CuAAC reakcióval állítottak elő ösztron-BODIPY konjugátumokat, alkin partnerként 17 $\alpha$-etinilösztradiolt (42) alkalmazva (33. ábra). Ariljodidként a festékmolekula szerepelt, a jód a pirrol (88) vagy a mezo-helyzetü fenilcsoport (91) szubsztituense volt. A reakció $\mathrm{Pd}\left(\mathrm{PPh}_{3}\right)_{2} \mathrm{Cl}_{2}$ katalizátorral, réz(I)jodid segédkatalizátorral, $\mathrm{Et}_{3} \mathrm{~N}$ bázis jelenlétében THF oldószerben szobahőmérsékleten 2-6 óra alatt lejátszódott. A mezo helyzetű kapcsolást egy nyolc szénatomos távoltartó linkeren keresztül is megvalósították (93). ${ }^{129}$ 

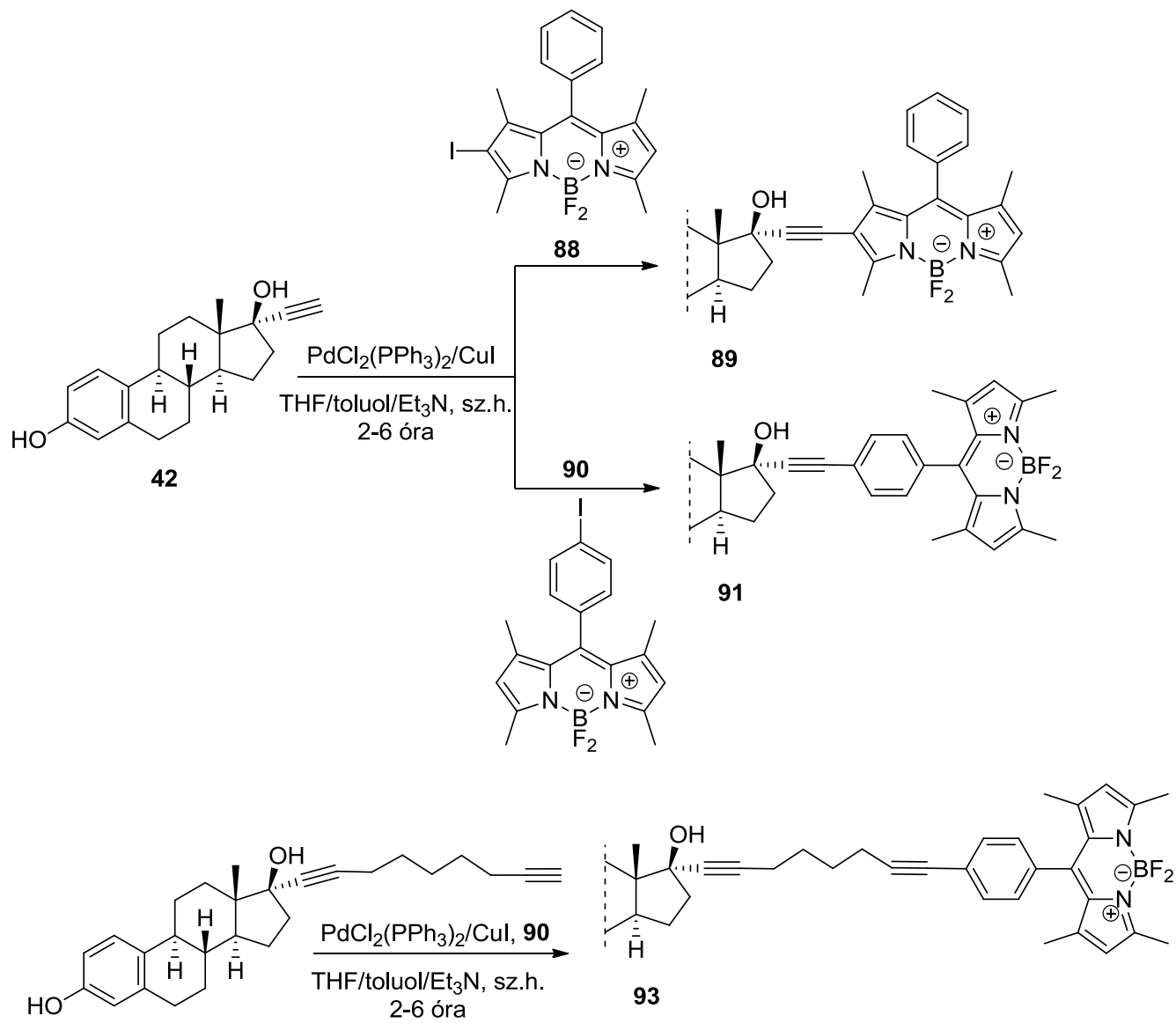

92

33 ábra 17a-helyzetben Sonogashira kapcsolással előállított BODIPY jelzett ösztradiolok

Aza-BODIPY származékokkal is történtek Sonogashira kapcsolások kétféle ariljodiddal (34. ábra). Azért volt szükség a kétféle jód-BODIPY $(94,96)$ használatára, mert vizsgálni kívánták a kapott konjugátumok spektrális és biológiai tulajdonságait. ${ }^{130,131}$ Az irodalomból ismeretes, hogy a pirrol alkotóelemek szubsztituálásával megváltoznak a fotometriai jellemzők. Amennyiben sikerül eltolni a jelölt vegyület abszorpciós és fluoreszcens emissziós hullámhosszát a közeli infravörös tartományba, terápiás és diagnosztikai szempontból ígéretesebb vegyületek tervezhetők. Tudomásunk szerint a vegyületek biológiai vizsgálatai még folyamatban vannak, de a kutatók szerint ezen származékok bizonyos képalkotó eljárásokban használhatók lehetnek. 


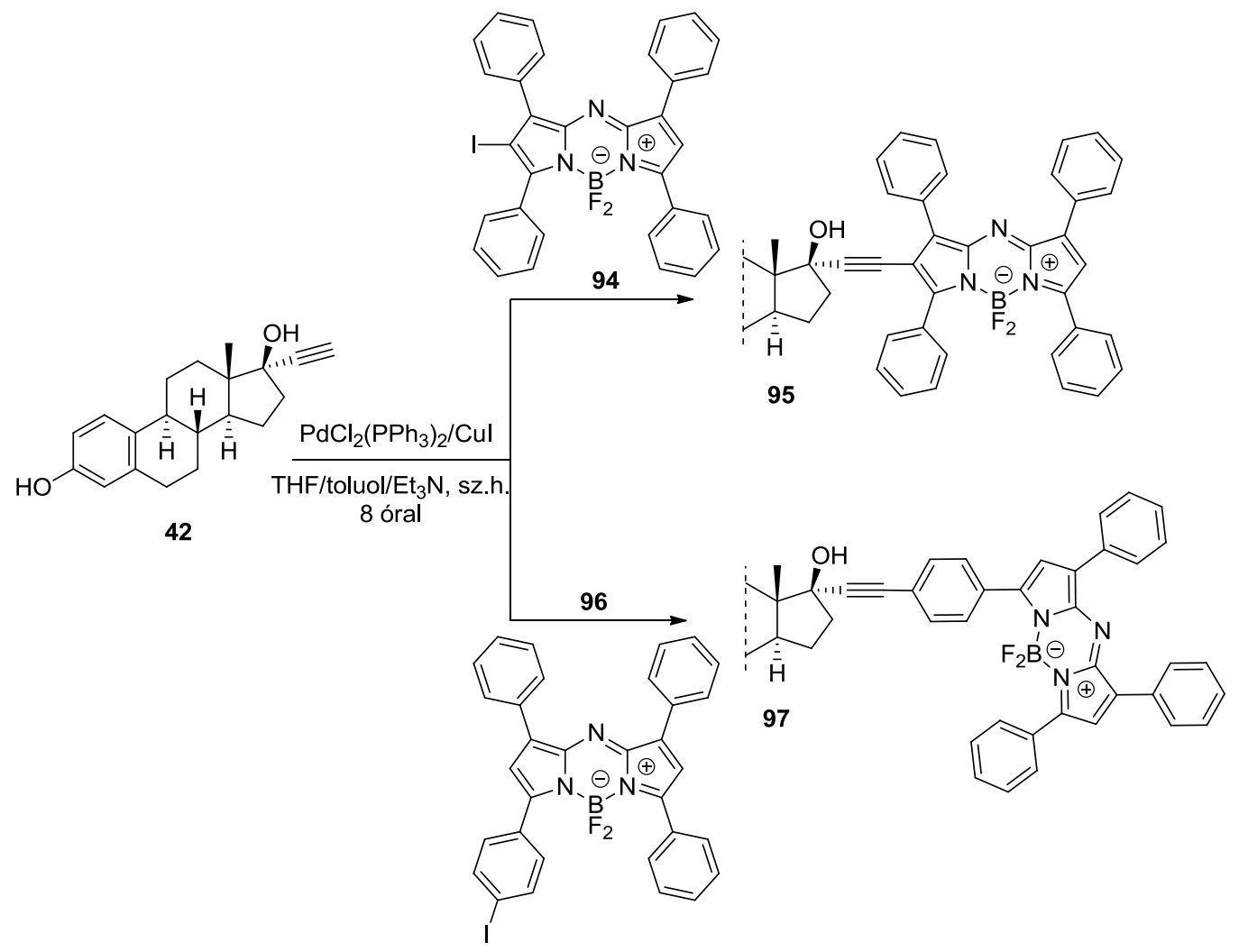

34. ábra Arilszubsztituált BODIPY-vel $(\mathbf{9 4 , 9 6 )}$ jelölt ösztradiolok elöállítása

Nemcsak Sonogashira kapcsolással, hanem CuAAC reakcióval is állítottak elő ösztronBODIPY konjugátumokat 17a-etinil-ösztradiolból (42) (35. ábra). A kapcsolást a klasszikus „click” reakció körülményei között $\mathrm{CuSO}_{4}$-böl Na-aszkorbáttal in situ gerenerált $\mathrm{Cu}(\mathrm{I})$ katalizátor segítségével hajtották végre. Segédreagensként trisz(benziltriazolilmetil)amint (TBTA), oldószerként ${ }^{t} \mathrm{BuOH} / \mathrm{THF} /$ víz 2,5:1:1 arányú elegyét alkalmazták. ${ }^{129}$ A BODIPYazidot közvetlenül (99) és linkeren keresztül (100) is hozzákapcsolták a szteroidhoz. A közvetlen kapcsolással kapott konjugátum biológiai szempontból ígéretesebbnek mutatkozott. 


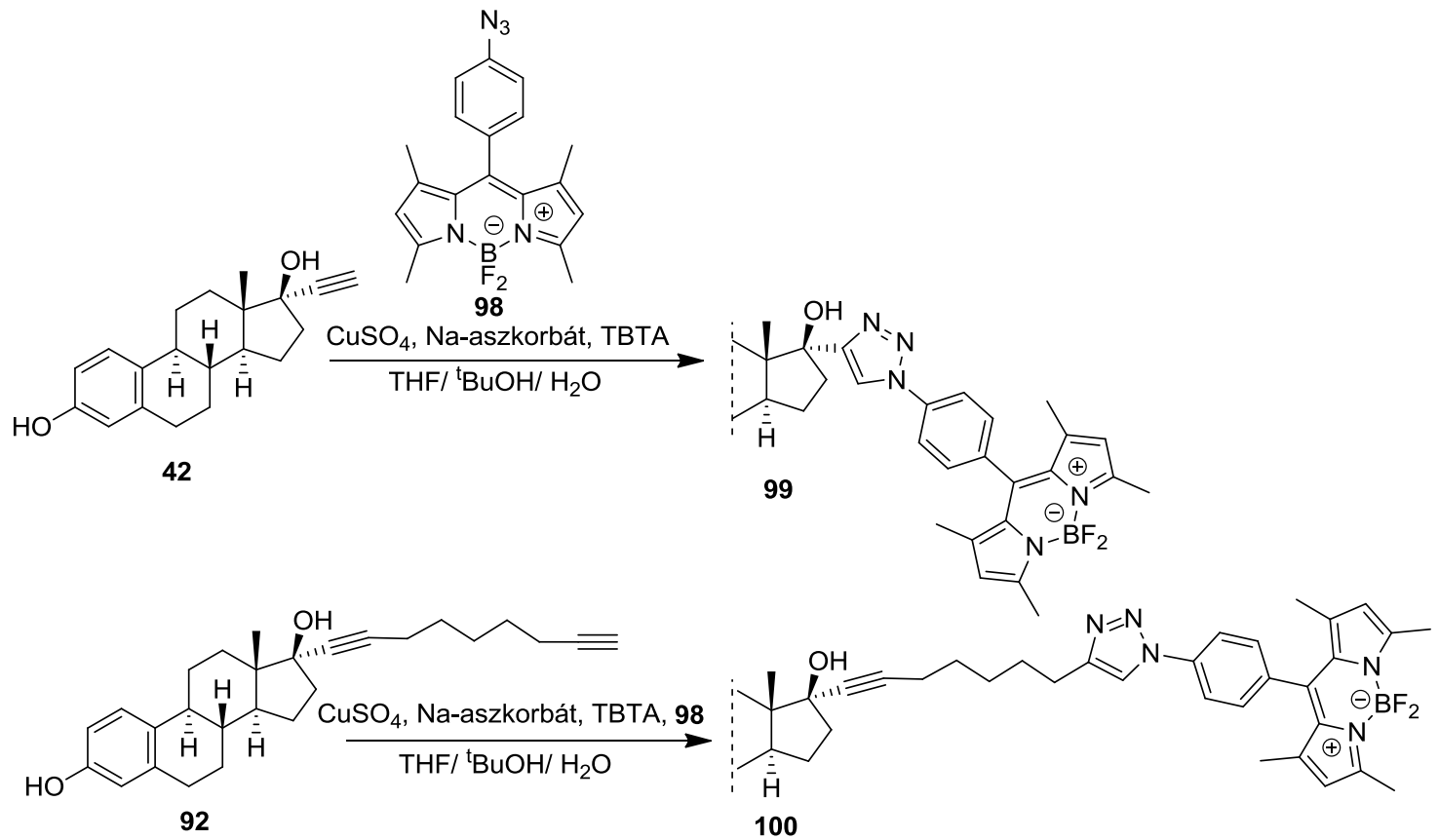

35. ábra CuAAC reakcióval előállított ösztradiol származékok $(\mathbf{9 9}, \mathbf{1 0 0})$ 


\subsection{Biológiai előzmények}

\subsubsection{Az A-gyürüben módosított ösztron származékok biológiai vonatkozásai}

Az ösztrogénfüggő tumorok kezelésének hatékony módja lehet az ösztrogén hormonok bioszintézisében részt vevő három kulcs enzim (STS, aromatáz, 17 $\beta$-HSD1) inhibitorainak alkalmazása (1. fejezet, 1. ábra). ${ }^{2-6}$ Jelen fejezetben azt tárgyaljuk, hogy a szakirodalomban ismeretes enzimgátló vegyületek, szerkezetüktől függően, milyen hatást fejtenek ki. Kitérünk arra is, hogy ezen enzimek esetében mennyire tervezhetők az inhibitorok a fehérjék kristályszerkezetének ismeretében. Egy összefoglaló közlemény ${ }^{132}$ arról számol be, hogy a három említett enzim háromdimenziós szerkezetének meghatározása nem váltotta be a várt reményeket. Kísérleti adatokkal sikerült igazolni, hogy a három különböző aktív centrummal és katalitikus mechanizmussal rendelkező enzim hasonló szerkezetü, ösztron-alapú inhibitorokkal gátolható. Különösen igaz ez a természetes ösztron A-gyürüben halogénezett származékaira. Az irodalmi adatok azt sugallják, hogy a 2-es helyzetű szubsztitúció a 17ßHSD1 és az aromatáz enzimek, míg a 4-es a STS gátlásához vezet. A szakirodalom azonban nem ismerteti a 2,4-bisz-halogénvegyületek gátlási potenciálját, továbbá arra sincsenek egyértelmü összefüggések, hogy a 17-es ketocsoport jelenléte szükséges-e a hatás kifejtéséhez.

Mindezek alapján több kutatócsoport foglalkozik STS inhibitorok előállításával. Egyik fontos irányvonal az ösztron-alapú hatóanyagok kifejlesztésénél a 3- és/vagy 17-szulfamátok kialakítása volt. A 3-as helyzetben ily módon átalakított ösztron olyan funkciós csoportot tartalmaz, amely hasonlít a STS enzim szulfátjáéhoz. Az ösztron sorbeli 3- vagy 17-szulfamát inhibitorok a nanomólos tartományban gátolják az enzim müködését, viszont egyes ilyen képviselők jelentős ösztrogén aktivitással rendelkeznek, amely gátat szab azok tumorellenes szerként való alkalmazásának. ${ }^{133,134}$ Brit kutatók olyan ösztron-3-O-szulfamát származékokat is vizsgáltak, amelyek nem tartalmaznak a 17-es helyzetben oxocsoportot. Az EMATE-ról (101) (36. ábra) igazolták, hogy nanomólos $\mathrm{IC}_{50}$ értékkel gátolja a mikroszómális STS enzimet. ${ }^{135}$ Megállapították tehát, hogy a 3-szulfamát esetében a 17-es oxocsoport jelenléte nem szükséges az enzim inhibitor hatás kifejtéséhez.

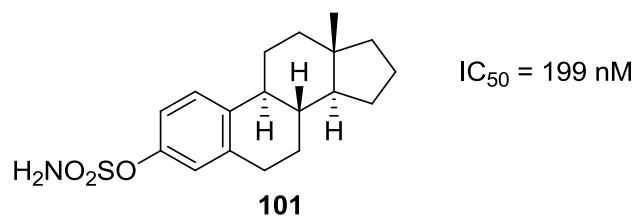

36. ábra A 17-dezoxi ösztron 3-szulfamátja 
3-as helyzetben hidroxilcsoportot tartalmazó ösztron-alapú STS inhibitorok is ismeretesek. Ezek az aromás A-gyürüben halogéneket tartalmaznak. Az ösztron maga elenyésző affinitással kötődik az enzimhez, azonban A-gyürüjére 4-es pozícióba halogéneket $(\mathbf{3 0}, \mathbf{1 0 4})$ vagy kis elektronszívó csoportot (nitril, formil, nitro) beépítve hatékony STS-inhibitorok nyerhetők. (37. ábra). ${ }^{19}$ Feltételezések szerint a halogén elektronikus tulajdonságai révén megváltoztatja a 3-as hidroxilcsoport hidrogénkötés kialakítására mutatott hajlamát, továbbá sztérikusan is befolyásol

Az aromatáz az egyetlen olyan enzim a gerincesek szervezetében, amely képes a hattagú gyürü aromatizálására, így ennek szelektív gátlása, specifikusságának köszönhetően, nem befolyásolja a többi szteroid bioszintézisét. A klinikai gyakorlatban használt tumorellenes szerek gyakran ezt az enzimet célozzák. ${ }^{136,137}$ Szteroid-típusú inhibitorai általában nem ösztron-alapúak, ugyanis az enzim nem aromás szteránvázas vegyületeket használ szubsztrátumként. Ritkább esetben, de előfordul, hogy az enzimreakció termékét választják alapul inhibitorok kifejlesztéséhez. Az aromatáz enzimet illetően is kitűnt, hogy az ösztron 2es pozícióban halogénezett származékai $(\mathbf{2 8}, \mathbf{1 0 2}, \mathbf{1 0 3})$ hatékonyan gátolják az enzim müködését (37. ábra). ${ }^{18} \mathrm{~A}$ 2-klór származék (103, inhibitor állandó: $\left.\mathrm{K}_{\mathrm{i}}=0.13 \mu \mathrm{M}\right)$, enzimhez való affinitása 20 -szorosa a természetes ösztronénak $\left(2, \mathrm{~K}_{\mathrm{i}}=2.5 \mu \mathrm{M}\right)$. A 4-es pozícióba halogén beépítése azonban, a fluor kivételével, jelentősen lecsökkentette az enzimhez való kötődést.

Szulfatáz gátlók<smiles>C[C@]12CC[C@@H]3c4ccc(O)c([Hg])c4CC[C@H]3[C@H]1CCC2=O</smiles>

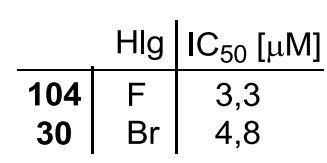

Aromatáz gátlók

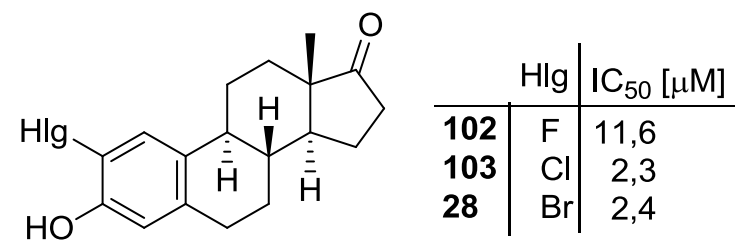

37. ábra A-gyürüben halogénezett hatékony enzim inhibitorok szerkezete és $\mathrm{IC}_{50}$ értékeik

Az emlő egyes daganatos elváltozásai összefüggésbe hozhatók a 17ß-HSD1 fokozott lokális aktivitásának következtében kialakuló emelkedett szöveti $17 \beta$-ösztradiol koncentrációval. ${ }^{138}$ A 17ß-HSD1 enzim mint NADPH-függő ketoszteroid-reduktáz ${ }^{6}$ fontos célpontja lehet tehát az emlőrák hormonterápiájának. Több szteroid- ${ }^{139,140}$ és nem szteroid-jellegü ${ }^{141,142}$ inhibitort is fejlesztettek a 17ß-HSD1-re, azonban ezek közül egy sem jutott még el a klinikai alkalmazásig. A legjobb ösztron-alapú gátlók szinte mindegyike különböző mértékü 
receptoriális ösztrogén hatást is mutat. A szelektíven ható 17ß-HSD1-inhibitorok kifejlesztése tehát továbbra is nagy kihívást jelent a gyógyszerkémikusok számára. A szteroidokból képzett inhibitorok között számos szubsztituált és heterociklusos ösztronszármazék ismeretes ${ }^{6}$, amelyek általában fenolos $\mathrm{OH}$-csoportot tartalmaznak az ösztránváz 3as szénatomján, továbbá 17-ketovegyületek. Irodalmi adatok szerint ugyanis ezen két funkciós csoport (3-OH és 17-oxo) jelenléte és megfelelő távolsága szükséges az enzim szubsztrátkötő helyéhez való kötődéshez. Az ösztradiollal komplexált 17ß-HSD1kristályszerkezete irodalomból ismert. ${ }^{143}$ Molekuladinamikai számítások és fehérje-ligandum dokkolási vizsgálatok rámutattak, hogy egy lipofil zseb található a komplexált ösztradiol 2-es szénatomjának közelében. ${ }^{57}$ Ennek alapján a 2-es helyzetbe lipofil molekularészlet beépítésével az enzim-ligandum kölcsönhatás erőssége megnövelhető, és ezáltal potens inhibitorok fejleszthetők. Möller és munkatársai igazolták hogy az ösztron vagy a Dhomoösztron 2-es szénatomjára halogént, fenetil- vagy fenetinilcsoportot beépítve fokozódik az inhibitor hatás (38. ábra). Az utóbb felsorolt vegyületek nanomólos $\mathrm{IC}_{50}$-értékkel gátolják az enzim működését.

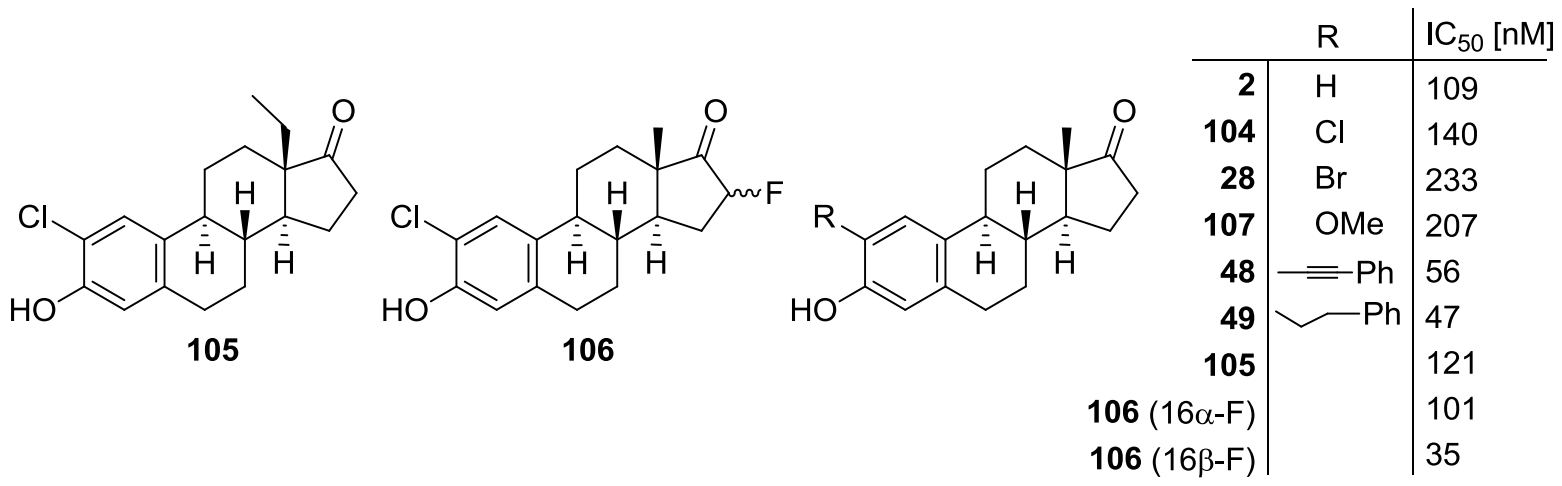

38. ábra Ösztron alapú 17ß-HSD1 inhibitorok

Összefoglalva az eddig említett előzményeket, kitűnik, hogy az ösztrán váz A-gyürüjének 2es vagy 4-es szénatomjára hasonló szubsztituenseket beépítve három különböző enzim gátlása is megvalósítható. Azonban fontosnak tartjuk megjegyezni, hogy a szakirodalmi adatok hiányosak olyan szempontból, hogy nincs egy szisztematikus összefoglaló tanulmány arra vonatkozóan, amelyből az egyes regioizomerek három enzimre való potenciális gátló hatása összehasonlítható lenne. Az ilyen átfogó vizsgálatok eredményei hasznos szerkezethatás összefüggéseket tárhatnának fel. A három enzim közül kizárólag az aromatáz vonatkozásában ismeretes olyan szteroid-alapú készítmény, amely terápiás alkalmazásban van, a másik két enzim gátlói közül egy sem jutott még el klinikai kipróbálásig. Ennek oka 
leggyakrabban a hatékony inhibitorok visszamaradó ösztrogén hatásában rejlik. Munkánk ezen a ponton kapcsolódik az ez idáig ebben a témakörben folyt kutatásokhoz. Doktori munkámban olyan potenciális enzim inhibitorok előállítását terveztük, amelyek hormonálisan inaktív alapvegyületből (13 $\alpha$-ösztron) kerülnek előállításra, így várhatóan szelektív hatású új vegyületek lehetnek. Munkánk értékét növelheti, ha sikerül olyan új származékokat azonosítanunk, amelyek a három enzim közül nemcsak egy, hanem kettő gátlására is képesek.

A szakirodalomból ismeretes, hogy nemcsak az ösztron 13-as szénatomjának konfiguráció változtatása, hanem annak adott helyzetben való aminálása is csökkent ösztrogén aktivitáshoz vezet (39. ábra). ${ }^{144} \mathrm{Az}$ aromás gyürü 2-es vagy 4-es szénatomjára aminocsoportot építve olyan származékok nyerhetők, amelyek csökkent kötődési affinitást mutatnak az ösztrogén magreceptorokhoz. A 2- és a 4-aminoösztron (107, 108), illetve azok 3-metiléterének bizonyos származékai szerteágazó biológiai aktivitással, többek között enzimgátló vagy antiproliferatív hatással rendelkeznek. A 2-brómacetamido-ösztron-3-metiléter irreverzibilisen gátolja a 17ß-HSD1 enzim müködését. ${ }^{145}$ Ugyancsak az ösztron 3metiléterének 2- és 4-amino származékából savkloriddal komplexképzésre alkalmas DTPA (2-(bisz(2-(2,6-dioxomorfolino)etil)amino) csoportot építettek be török kutatók. Ezután metastabil ${ }^{99 \mathrm{~m}} \mathrm{Tc}$ izotópot tartalmazó radiojelölt ösztron komplexet állítottak elő, és vizsgálták a komplex szövet szerinti eloszlását a szervezetben. ${ }^{146}$ A közelmúltban több kutatócsoport a 2-es és 4-es helyzetű aminocsoport átalakításával állított elő olyan ösztron származékokat ${ }^{147}$ amelyek kiemelkedő tumorellenes hatást mutattak. Ide tartoznak az $N$-aril szelenokarbamid ${ }^{148}$ valamint a dimetil-trienazil származékok is. ${ }^{149}$ A 3-aminoösztron (67) szintén értékes biológiai aktivitással rendelkezik, ugyanis STS inhibitor és in vivo nem mutat ösztrogén aktivitást. $^{150}$

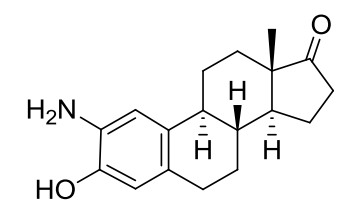

107

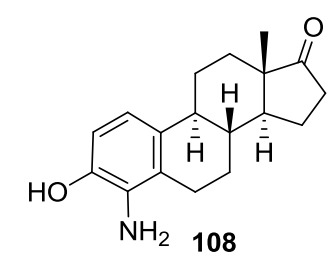

108

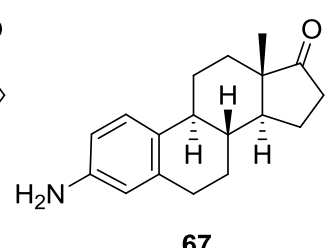

67

39. ábra A gyürüben szubsztituált aminoösztronok $(\mathbf{6 7}, \mathbf{1 0 7}, \mathbf{1 0 8})$ 


\subsubsection{A fluoreszcensen BODIPY-vel jelölt ösztron származékok biológiai vonatkozásai}

Az ösztron BODIPY-alapú fluoreszcens festékkel való jelölésére csupán néhány példa található az irodalomban. A kutatók az ösztrán váz $7 \alpha$ - vagy a 17 1 -pozícióit választották a jelöléshez, ugyanis az volt a céljuk, hogy olyan jelölt szteroidot állítsanak elö, amely képes az ösztrogén magreceptorokhoz való kötődésre. Az ilyen származékok alkalmas alapvegyületek lehetnek diagnosztikai képalkotó eljárások vagy fluoreszcencia mérésén alapuló molekuláris biológiai vizsgálati módszerek kifejlesztéséhez.

A 40. ábrán látható származékok esetében a módosítások nem befolyásolják a fő oxigéntartalmú funkciós csoportok közötti távolságot, ezért ez a két ösztradiol származék képes az ösztrogén magreceptorokhoz való kötődésre. A $7 \alpha$ - és a 17a-helyzetbe megfelelő hosszúságú linkeren keresztül nagyobb térkitöltésü csoportok is beépíthetők anélkül, hogy lényeges változás következne be a vegyületek receptorkötődési sajátságaiban.
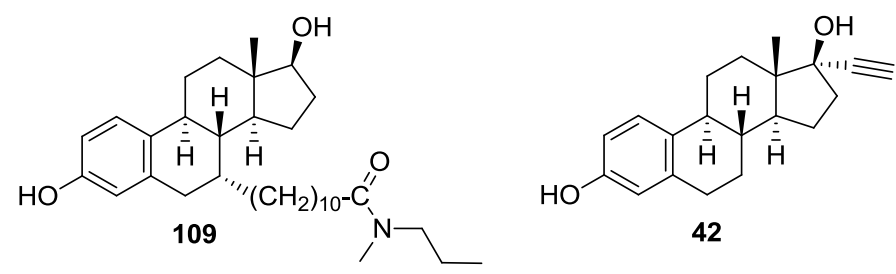

40. ábra 7 $\alpha$ - és $17 \alpha$ - helyzetben szubsztituált ösztron származékok $(\mathbf{4 2}, \mathbf{1 0 9})$

A fentiek alapján két kutatócsoport is állított elő $7 \alpha$-helyzetben linkeren keresztül jelölt ösztron származékot $(\mathbf{8 1}, \mathbf{8 5})$ (41. ábra). ${ }^{127,128}$ Mindkét konjugátumban hosszú linker köti össze a két szerkezeti elemet, és ennek köszönhetően mindkét vagyület nagy affinitást mutatást az ösztrogén magreceptorokhoz in vitro. A 85 jelü konjugátumról in vivo kísérletekkel is igazolták a vegyület ösztrogén hatását. A kutatók szerint a konjugátumaik alkalmasak lehetnek ösztradiol-érzékeny sejtek fluoreszcencián alapuló vizsgálatára. Azonban nincs tudomásunk arról, hogy az ilyen 7 $\alpha$-helyzetben konjugált ösztron-BODIPY származékokra alapozva molekuláris biológiai eljárást fejlesztettek volna.

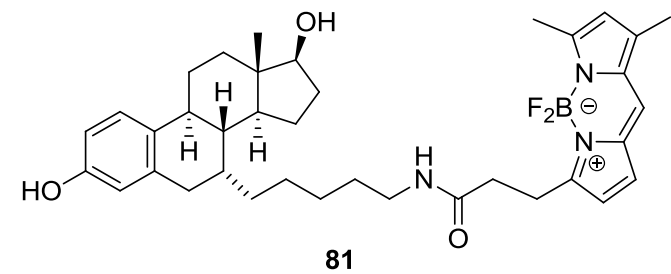

81

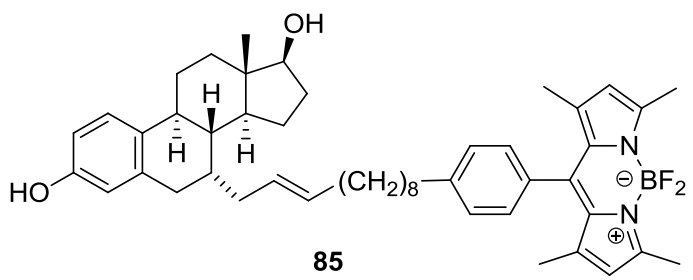

85 
A Sonogashira kapcsolással 17 $\alpha$-helyzetben jelölt vegyületekről (42. ábra) még csak az előzetes biológiai vizsgálatok eredményei állnak rendelkezésre, amelyek szerint a vegyületek képesek lokalizálódni az ER-pozitív emlő tumorsejtekben. ${ }^{129}$ A 93-as jelű vegyület radioszubsztrát enzim kötődési vizsgálatokban kimutatható affinitást mutatott az ER $\alpha$-hoz. ${ }^{129}$ Ez az ígéretes eredmény további ösztron-BODIPY konjugátumok szintézisét teszi időszerűvé.
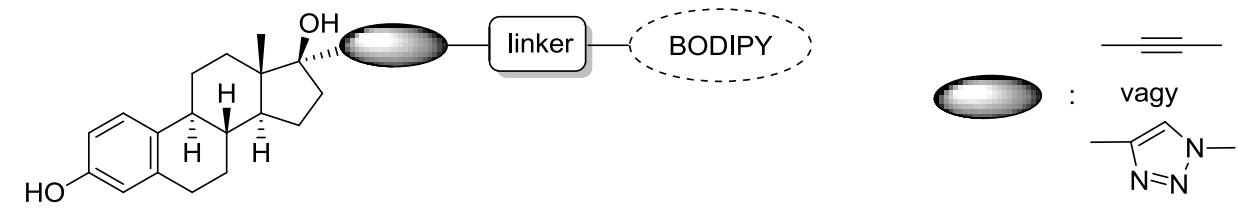

$89,91,39,95,95,97,99,100$

42. ábra A 2.1.6. fejezetben tárgyalt 17 $\alpha$-helyzetben BODIPY-vel jelölt ösztron származékok Biológiai szempontból nemcsak az olyan fluoreszcens ösztron-BODIPY konjugátumok előállítása lehet fontos, amelyek az ösztrogén magreceptorokhoz való kötődési sajátságokkal rendelkeznek. Amennyiben sikerül olyan ösztron konjugátumot előállítani, amely az ösztronhoz hasonló affinitást mutat olyan enzimeken, amelyeknek a természetes ösztron a szubsztrátuma, fluoreszcencia mérésén alapuló biokémiai eljárások fejleszthetők. Az ösztron bioszintézisében részt vevő kulcs enzimek egyikének, a 17ß-HSD1-nek kiváló gátlói a 2-es helyzetben szubsztituált ösztron származékok ${ }^{57}$ Továbbá egyes 15 -szubsztituált származékok (110, 111), a linker hosszától és térállásától függetlenül is hatékony 17 $\beta$-HSD1 inhibitornak bizonyultak (43. ábra). ${ }^{6,151}$ Ezek alapján ígéretes lehet az ösztron 2-es vagy 15-ös helyzetben BODIPY festékkel való jelölése is.
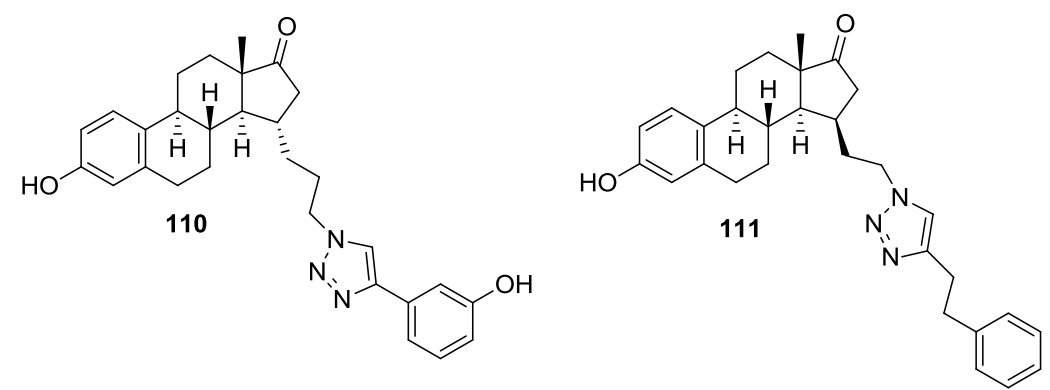

43. ábra 15a-helyzetben szubsztituált ösztron származékok $(\mathbf{1 1 0}, \mathbf{1 1 1})$ 


\section{Kísérleti eredmények}

\subsection{Halogénezés}

\subsubsection{Jódozás}

Munkánk kezdeti szakaszában a tervezett keresztkapcsolási reakciók alapanyagaiként

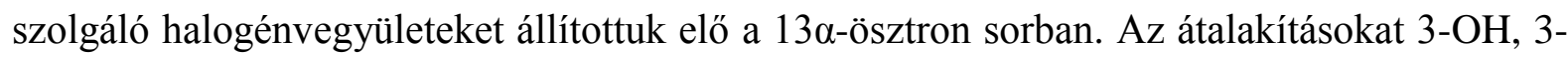
OMe és 3-OBn csoportot tartalmazó származékokból is megvalósítottuk. I Vizsgálni kívántuk a 3-as helyzetű szubsztituens kémiai minőségének befolyását a halogénezési reakciókra. Háromféle halogén beépítését terveztük: jód, bróm és klór. Célunk minél többféle aromás A-

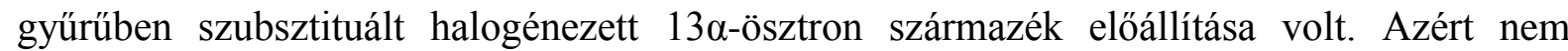
törekedtünk a regioszelekivitásra, mert terveztük az előállított halogénvegyületek biológiai vizsgálatát, és fontosnak tartottuk, hogy minél többféle származék álljon rendelkezésünkre a szerkezet-hatás összefüggések megállapításához.

A halogénezési reakcióink sorát a jódozással kezdtük, melyet egy az irodalmi előzményekben ismertetett módszerrel végeztünk. ${ }^{32}$ A $13 \alpha$-ösztront $(\mathbf{6}(\mathrm{H})) 1$ ekvivalens NIS-del reagáltattuk TFA-ban szobahőmérsékleten (44. ábra, 1. táblázat, 1. Sor). A reakció teljes konverzióval játszódott le, és 2 termék képződését tapasztaltuk, 1:1 arányban $(\mathbf{1 1 3}, \mathbf{1 1 4})$. Két ekvivalens NIS alkalmazásakor a 2,4-bisz-jód vegyület (115) is képződött 47\%-os hozammal (1. táblázat, 2. Sor). Ezt a módszert kiterjesztettük a 3-metiléterre $(6(\mathrm{H}))$ is. Ugyanezen körülmények között itt is csak a 2- és a 4-monojód származék $(\mathbf{1 1 6}, \mathbf{1 1 7})$ képződött, közel azonos arányban (44. ábra, 1. táblázat, 3. sor). A 3-metilérnél 2,4-bisz származék képződését nem tapasztaltuk. A nagy reagens felesleg (2 ekvivalens) és a melegítés sem segítette elő a kétszeres szubsztitúciót, szemben a szabad hidroxilcsoportot tartalmazó vegyület reakcióival (1. táblázat, 4. sor). Az eltérő viselkedés oka lehet az aromás gyürün a 3-as helyzetű funkciós csoportok $(\mathrm{OH}, \mathrm{OMe}, \mathrm{OBn})$ különböző térkitöltése és elektronikus tulajdonságai. A sikeres

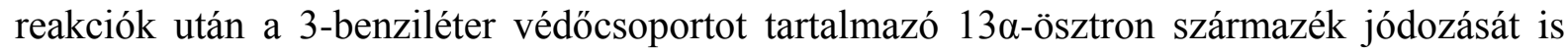
megkíséreltük a már ismertetett reakciókörülmények között (1. táblázat, 5. sor). Azt tapasztaltuk, hogy nem a várt termékek képződtek, hanem szabad fenolos hidroxilcsoporttal rendelkező jódvegyületek (113-115). Ennek magyarázata lehet, hogy először a TFA hatására lehasad a benzil védőcsoport, majd az így felszabaduló fenolos hidroxilcsoport mellett a

\footnotetext{
${ }^{\prime}$ Bacsa I., Jójárt R., Schneider G., Wölfling J., Maróti P., Herman B.E., Szécsi M., Mernyák E. Synthesis of A-ring halogenated $13 \alpha$-estrone derivatives as potential 17 $\beta$-HSD1 inhibitors. Steroids 2015, 104, 230-236.
} 
6(H)-s vegyületnél már leírt módon megy végbe a szubsztitúció. A 3-O-benzil-jódösztronok előállításának érdekében további próbareakciókat végeztünk különböző polaritású oldószerekben (1. táblázat, 6-10. sor), és egy esetben az oxidatív jódozás körülménye között (1. táblázat, 10. sor) is megpróbáltuk előállítani a céltermékeket. Azonban egyik körülmény sem bizonyult hatékonynak. A 3-benziléter vegyület jód származékait nem sikerült ezzel a módszerrel elöállítani.

A jódozási reakciót nemcsak 17-ketonokon, hanem 17-dezoxi-vegyületeken is vizsgálni kívántuk, ugyanis a 17-es ketocsoport jelenléte vagy hiánya nemcsak a szerves kémiai folyamatok lefutását, hanem a céltermékek biológiai hatását is nagymértékben befolyásolhatja. Annak érdekében, hogy rendelkezésünkre álljon a 17-dezoxi-13 $\alpha$-ösztron is, a kutatócsoportunk által korábban már kidolgozott módszerrel ${ }^{152,16}$ eltávolítottuk a 17-es oxocsoportot. Az így nyert vegyületből (112) 1,5 ekvivalens NIS alkalmazásával, rövid reakcióidővel nyertük a kívánt céltermékeket, $118: 119: 120=1: 1: 2$ (24:26:48\%) arányban (44. ábra, 1. táblázat, 11. sor). ${ }^{\text {II }}$ A jódozás esetében nem tapasztaltunk jelentős különbséget a termékelegy összetételében a 17-oxovegyülethez $(6(\mathrm{H}))$ képest, azonban a 17dezoxi-vegyületnél (112) kevésbé tolódik a termékarány a 2,4-bisz-vegyület képződésének irányába.

"Bacsa I., Herman B. E., Jójárt R., Herman K. S., Wölfling J., Schneider G., Varga M., Tömböly C., Rižner T. L., Szécsi M., Mernyák E. Synthesis and structure-activity relationships of 2- and/or 4-halogenated $13 \beta$ - and $13 \alpha$-estrone derivatives as enzyme inhibitors of estrogen biosynthesis; Journal of Enzyme Inhibition and Medicinal Chemistry, 2018, közlésre beküldve 

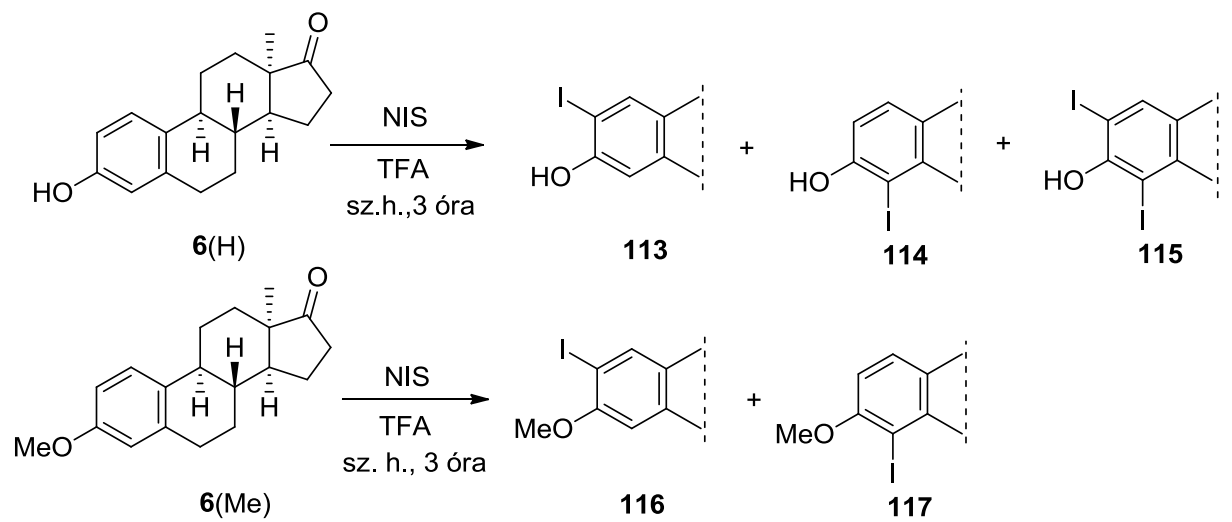

113

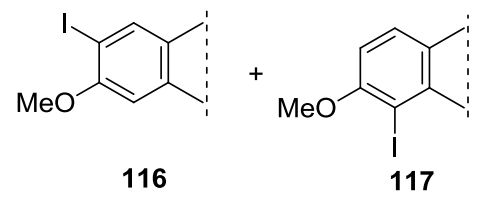

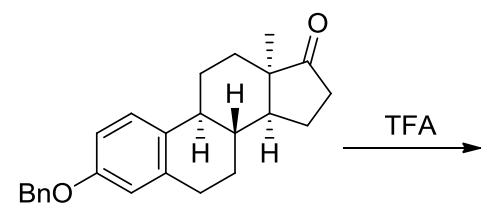

6(Bn)

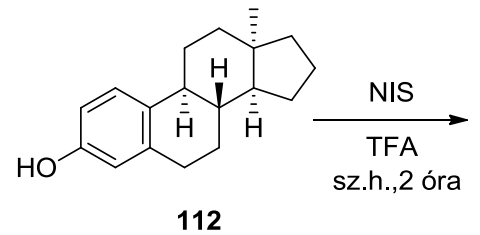

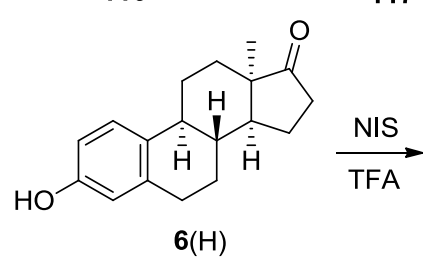

(118
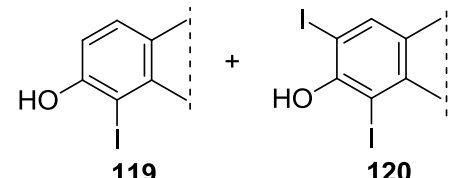

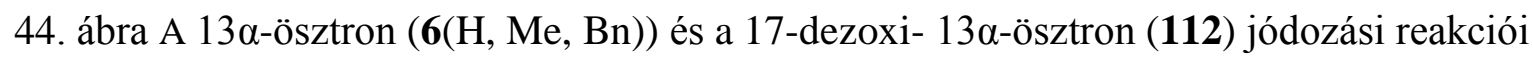
1. táblázat A 6(H, Me, Bn) és 112-es vegyületek jódozása

\begin{tabular}{|c|c|c|c|c|c|}
\hline Sor & $\begin{array}{c}\text { Kiindulási } \\
\text { vegyület }\end{array}$ & $\begin{array}{c}\text { Elektrofil } \\
\text { reagens }\end{array}$ & Oldószer & Termék & $\begin{array}{c}\text { Izolált hozam } \\
(\%)\end{array}$ \\
\hline 1 & $6(\mathrm{H})$ & NIS (1 ekv.) & TFA & $113+114$ & $43+45$ \\
\hline 2 & $6(\mathrm{H})$ & NIS (2 ekv.) & TFA & $113+114+115$ & $10+38+47$ \\
\hline 3 & 6(Me) & NIS (1 ekv.) & TFA & $116+117$ & $47+41$ \\
\hline 4 & 6(Me) & NIS (2 ekv.) & TFA & $116+117$ & $46+42$ \\
\hline 5 & $\mathbf{6}(\mathrm{Bn})$ & NIS (1 ekv.) & TFA & $113+114+115$ & $11+36+43$ \\
\hline 6 & $\mathbf{6}(\mathrm{Bn})$ & NIS (1 ekv.) & THF & $\begin{array}{l}\text { nincs átalakulás } \\
\text { (n.á.) }\end{array}$ & - \\
\hline 7 & $\mathbf{6}(\mathrm{Bn})$ & NIS (1 ekv.) & $\mathrm{CH}_{2} \mathrm{Cl}_{2}$ & n.á. & - \\
\hline 8 & $\mathbf{6}(\mathrm{Bn})$ & NIS (1 ekv.) & $\mathrm{MeCN}$ & n.á. & - \\
\hline 9 & $\mathbf{6}(\mathrm{Bn})$ & NIS (1 ekv.) & $\mathrm{MeCN}+\mathrm{TFA}$ & $113+114+115$ & $11+36+43$ \\
\hline 10 & $\mathbf{6}(\mathrm{Bn})$ & KI (1 ekv.) & $\mathrm{MeCN}+\mathrm{H}_{2} \mathrm{O}_{2}$ & n.á. & - \\
\hline 11 & 112 & NIS (1,5 ekv.) & TFA & $118+119+120$ & $24+26+48$ \\
\hline
\end{tabular}




\subsubsection{Brómozás}

Munkánkat a 13a-ösztron $(\mathbf{6}(\mathrm{H}))$ brómozásával folytattuk. A reakciót 1 ekvivalens NBS-del, THF-ban végeztük (45. Ábra; 2. táblázat, 1. sor). A brómozás rövid idő alatt, teljes konverzióval lejátszódott, 2,4-bisz-bróm (123) és 4-bróm származék (122) közel 1:1 arányú elegyét szolgáltatva. A 2-es regioizomer (121) képződése ilyen körülmények között nem volt megfigyelhető. Erre magyarázatot adhat az A-gyürü elektrofil szubsztitúcióban aktivált fenoljellege, amelynek köszönhetően a 2-brómvegyület továbbalakul 2,4-diszubsztituált származékká. Oldószer változtatásával kíséreltük meg a termékarány eltolását, ennek érdekében több próbareakciót is végeztünk. (2. táblázat, 2-6. sor) Kizárólag dimetilszulfoxidban (DMSO, 2. Táblázat 6. Sor) sikerült a szerkezet- és biológiai vizsgálatokhoz szükséges mennyiségü 2-szubsztituált (121) célterméket izolálni. A 3metiléter származékból $\left(\mathbf{6}(\mathrm{H})\right.$ diklórmetánban $\left(\mathrm{CH}_{2} \mathrm{Cl}_{2}\right)$ a monobróm regioizomerek $(\mathbf{1 2 1}$, 122) és 2,4-bisz-bróm származék (123) keverékét nyertük, amelyben a 4-es izomer (123) volt a főtermék (45. Ábra; 2. táblázat, 7. sor). A jódozási reakcióhoz hasonlóan, a 2,4-bisz-bróm termék képződése ebben az esetben sem volt megfigyelhető. A 3-benziléter (6(Bn)) brómozását NBS-del (45. ábra, i.) és 1,3-dimetil-5,5-dibróm-hidantoinnal (DDH) (45. ábra, ii.) is elvégeztük. Az első esetben nem volt teljes az átalakulás, azonban regioszelektíven csak a 2-es izomer (126) keletkezett (2. táblázat 8. sor). A második esetben már 100\%-os volt a konverzió, és 1:2 arányban képződött a két brómvegyület $(\mathbf{1 2 6}, \mathbf{1 2 7})$ (2. táblázat 9. sor). Nem várt eredmény, hogy ebben a reakcióban a térgátolt, 4-es helyzetben szubsztituált (127) vegyület képződött nagyobb arányban.

Kismolekulás rendszerben a térgátoltabb helyzetü szubsztitúció jelenségét a 6-metoxitetralonnál figyelték meg. ahol a keto funkció irányítja a szubsztitúciót. ${ }^{153} \mathrm{Az}$ analóg szerkezetü 6-metoxitetralin esetében a sztérikus hozzáférhetőségnek megfelelően nagyobb arányban képződik a 7-bróm-6-metoxitetralin. ${ }^{154}$ Ezek alapján megállapítható, hogy a ketocsoport jelenléte a tetralon esetében elősegíti a térgátoltabb helyzetben való szubsztitúciót.

A 17-dezoxi vegyület (112) brómozásakor mindhárom várt termék $(\mathbf{1 2 8}, \mathbf{1 2 9}, \mathbf{1 3 0})$ képződött 1,1 ekvivalens brómozószer hatására, 1:2:3 arányban (2. táblázat 10. sor). Összevetve az analóg 17-oxovegyülettel, kitűnik az eltérő kémiai viselkedés a D-gyürű szubsztituáltságától függően. 
Az aromás A-gyürű szubsztituálásánál a 17-dezoxi-vegyületnek a 17-oxovegyületétől eltérő viselkedésére pontos magyarázatot adni nem tudunk. A szteránvázas vegyületek átalakításainál többször megfigyelték, hogy az A- és a D-gyürük szubsztituáltsága és/vagy sztereokémiája befolyásolja egymás reakcióit. ${ }^{27,28}$

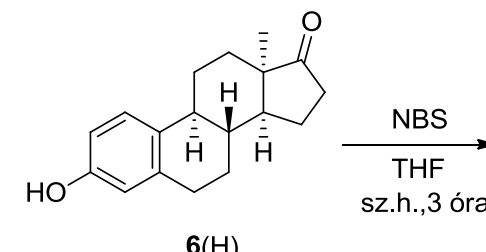

6(H)<smiles>COc1ccc2c(c1)CC[C@@H]1C2CC[C@]2(C)C(=O)CC[C@@H]12</smiles>

6(Me)<smiles>CCC[C@]12CC[C@H]3c4ccc(OCc5ccccc5)cc4CC[C@H]3[C@@H]1CCC2=O</smiles>

6(Bn)<smiles>Oc1cc2c(cc1Br)=CC=2</smiles>

121<smiles></smiles>

122<smiles>Oc1c(Br)cc(I)c(I)c1Br</smiles>

123<smiles>COc1cc(I)c(I)cc1I</smiles><smiles>Brc1cc(I)c(I)cc1OCc1ccccc1Oc1ccc(Oc2ccccc2)c(I)c1</smiles>

126

127<smiles>C[C@]12CCC[C@H]1C1CCc3cc(O)ccc3[C@@H]1CC2</smiles>

112<smiles>Oc1cc(I)c(I)cc1Br</smiles>

128<smiles>Oc1ccc2c(Br)c1I=I2</smiles>

129<smiles>Oc1c(Br)cc2cc1[IH]2</smiles>

130

45. ábra A 13 $\alpha$-ösztron (6(H, Me, Bn)) és 17-dezoxi származékának (112) brómozási reakciói

2. táblázat A 6(H, Me, Bn) és a 112-es vegyületek brómozása

\begin{tabular}{|c|c|c|c|c|c|}
\hline Sor & $\begin{array}{c}\text { Kiindulási } \\
\text { vegyület }\end{array}$ & $\begin{array}{c}\text { Elektrofil } \\
\text { reagens }\end{array}$ & Oldószer & Termék & $\begin{array}{c}\text { Izolált hozam } \\
(\%)\end{array}$ \\
\hline 1 & $\mathbf{6}(\mathrm{H})$ & NBS $(1$ ekv. $)$ & THF & $\mathbf{6}(\mathrm{H})+\mathbf{1 2 2}+\mathbf{1 2 3}$ & $45+49$ \\
\hline 2 & $\mathbf{6}(\mathrm{H})$ & NBS $(1$ ekv. $)$ & $\mathrm{CH}_{2} \mathrm{Cl}_{2}$ & $\mathbf{6}(\mathrm{H})+\mathbf{1 2 2}+\mathbf{1 2 3}$ & $43+47$ \\
\hline 3 & $\mathbf{6}(\mathrm{H})$ & NBS $(1$ ekv. $)$ & $\mathrm{MeCN}$ & $\mathbf{6}(\mathrm{H})+\mathbf{1 2 2}+\mathbf{1 2 3}$ & $44+47$ \\
\hline 4 & $\mathbf{6}(\mathrm{H})$ & NBS $(1$ ekv. $)$ & DMSO & $\mathbf{6}(\mathrm{H})+\mathbf{1 2 2}+\mathbf{1 2 3}$ & $45+48$ \\
\hline 5 & $\mathbf{6}(\mathrm{H})$ & NBS $(1$ ekv. $)$ & DMF & $\mathbf{6}(\mathrm{H})+\mathbf{1 2 2}+\mathbf{1 2 3}$ & $44+47$ \\
\hline 6 & $\mathbf{6}(\mathrm{H})$ & NBS $(1$ ekv. $)$ & DMSO & $\mathbf{1 2 1}+\mathbf{1 2 2}+\mathbf{1 2 3}$ & $24+35+38$ \\
\hline
\end{tabular}




\begin{tabular}{|c|c|c|c|c|c|}
\hline 7 & $\mathbf{6}(\mathrm{Me})$ & NBS $(1$ ekv. $)$ & $\mathrm{CH}_{2} \mathrm{Cl}_{2}$ & $\mathbf{1 2 4}+\mathbf{1 2 5}$ & $23+70$ \\
\hline 8 & $\mathbf{6}(\mathrm{Bn})$ & NBS $(1$ ekv. $)$ & $\mathrm{CH}_{2} \mathrm{Cl}_{2}$ & $\mathbf{1 2 6}$ & 91 \\
\hline 9 & $\mathbf{6}(\mathrm{Bn})$ & DDH $(1$ ekv. $)$ & $\mathrm{CH}_{2} \mathrm{Cl}_{2}$ & $\mathbf{1 2 6}+\mathbf{1 2 7}$ & $31+61$ \\
\hline 10 & $\mathbf{1 1 2}$ & NBS $(1,1$ ekv. $)$ & $\mathrm{CH}_{2} \mathrm{Cl}_{2}$ & $\mathbf{1 2 8}+\mathbf{1 2 9}+\mathbf{1 3 0}$ & $11+23+36$ \\
\hline
\end{tabular}

A 2-bróm 3-OH vegyület előállítása (121) sikeres volt a 2. táblázat 6. Sor szerinti módszerével, azonban ez az eljárás nagyobb mennyiség szintéziséhez nem bizonyult gazdaságosnak. A 13-as jelű vegyület nagyobb mennyiségben történő előállítását kerülő úton valósítottuk meg, a 3-O-benzil-2-bróm-13a-ösztronböl (126) Pd katalizált hidrogenolízissel (46. ábra).

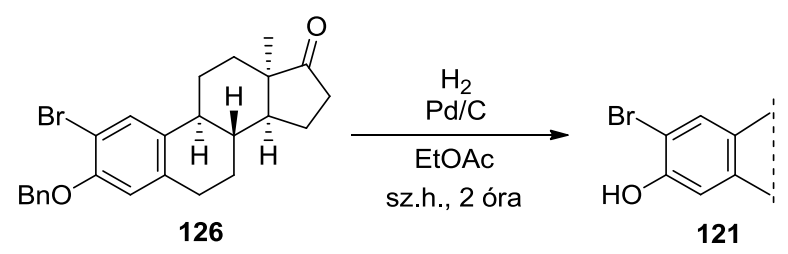

46. ábra A 3-O-benzil-2-bróm-13a-ösztron (126) védőcsoportjának eltávolítása

\subsubsection{Klórozás}

A 13 $\alpha$-ösztron (6(H)) klórozását NCS-del, TFA-ban végeztük (47. ábra, 3. táblázat 1. sor). A jódozáshoz hasonlóan itt is megfigyelhető volt, hogy 1 ekvivalens NCS hatására csak a monoszubsztituált vegyületek képződnek (131, 132), míg nagyobb reaktáns mennyiség alkalmazása esetén (3. táblázat 2. sor) megjelenik a bisz-klór származék (133) is. A 3metiléter $(6(\mathrm{Me}))$ klórozásakor TFA oldószerben csak a 4-klór származékokat $(\mathbf{1 3 4}, \mathbf{1 3 1})$ izoláltuk (47. ábra). A várttal ellentétben 2-klór (135) vegyület egyáltalán nem képződött, és a klórozást demetileződés kísérte (3. táblázat 3. sor). Feltételezésünk szerint a klórozás és a demetileződés a benziléternél tapasztaltakhoz képest fordított sorrendben játszódik le: első lépésben egy regioszelektív halogénezés történik, majd ezt követi a demetileződés. 6Metoxitetralon esetében szintén megfigyeltek hasonló szokatlan preferenciát a térgátoltabb helyzetű szubsztitúcióra 91:4 arányban. ${ }^{155}$ Annak érdekében, hogy a 2-es regioizomert (135) is előállítsuk, és visszaszorítsuk a mellékreakciókat, megváltoztattuk a reakcióközeg minőségét. $\mathrm{CH}_{3} \mathrm{CN}$-ben, katalitikus mennyiségű (0,3 ekvivalens) TFA-t alkalmazva közel 1:1 arányban keletkezett a 2-es (135) és a 4-es (131) izomer. (3. táblázat 4. sor) A megfelelő 
hatékonyság érdekében a reakcióelegyet $80{ }^{\circ} \mathrm{C}$-ra melegítettük. Ez a módszer jól kiterjeszthető a 3-benziléterre $(\mathbf{6}(\mathrm{Bn}))$ is (3. táblázat 5. sor). A reakció során a 2- (136) és 4klór vegyületeken (137) túl a 10-klór származék (36) képződése is megfigyelhető volt. A 10es helyzetü klórozódást már több kutatócsoport is megfigyelte korábban. Az irodalom szerint ez a klór $\beta$ térállású. Ennek a mellékterméknek a képződését a 3-metiléternél (6(Me)) nem, csak a 3-benziléter vegyületnél (6(Bn)) tapasztaltuk, ami annak köszönhető, hogy a benzil jobb távozó csoport, így az utóbbi esetben fokozottabban nyílik lehetőség ilyen típusú átalakulásra.

A 17-dezoxi származékból (112) kiindulva a 17-oxo vegyületnél alkalmazott klórozási körülmények között nem volt kimutatható reakció. Többféle reakciókörülmény kipróbálása után végül a reagens felesleg és a mikrohullámú besugárzás együttes alkalmazása bizonyult sikeresnek. 1,5 ekvivalens NCS hatására 2-es (138) és 4-es (139) monoszubsztituált vegyületek, míg 3 ekvivalens jelenlétében már a 2,4-bisz-klór származék (140) is keletkezett (47. ábra; 3. táblázat 6-7. sor).
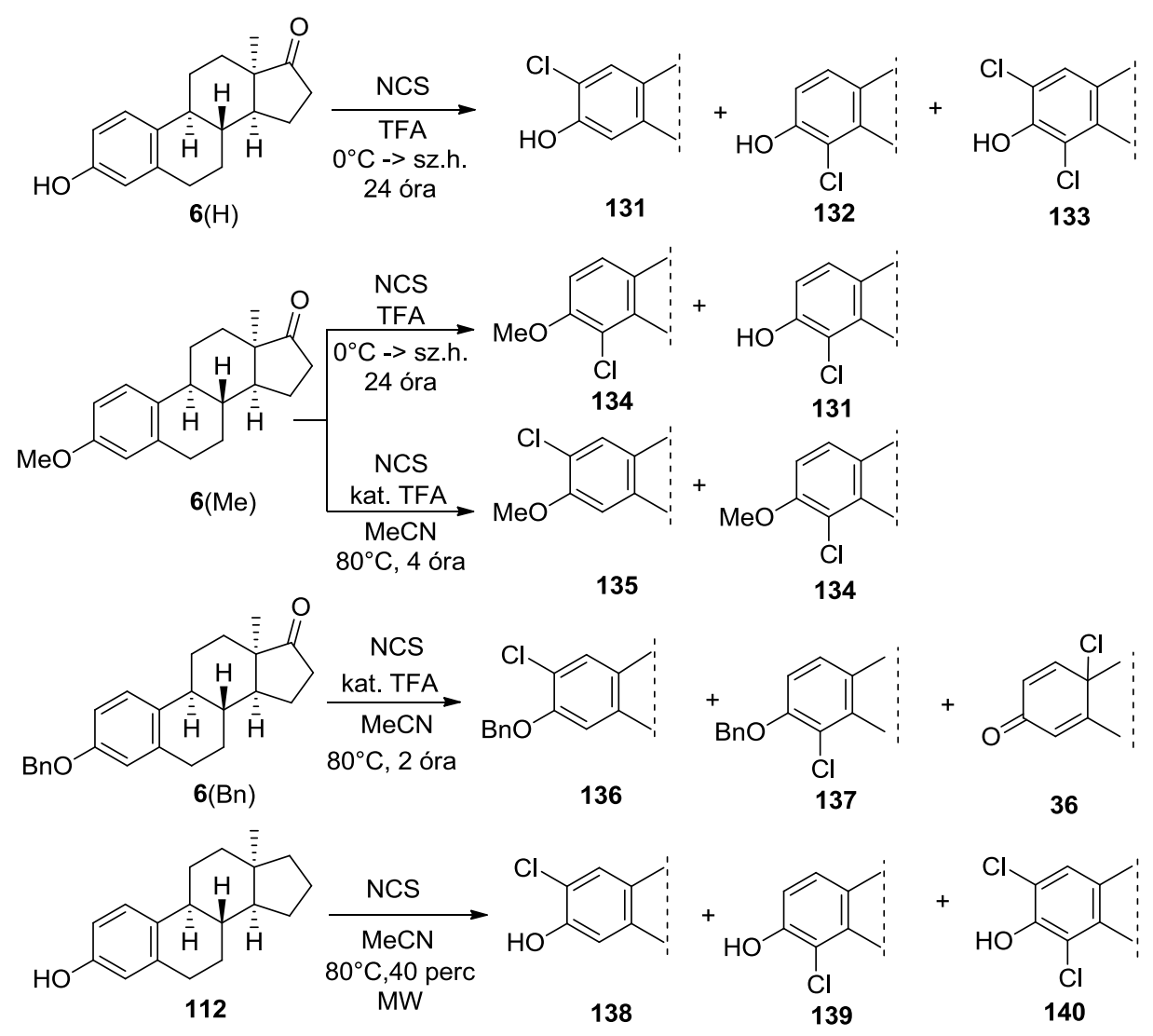

47. ábra A 13a-ösztron (6(H, Me, Bn)) és 17-dezoxi származékának (112) klórozási reakciói 
3. táblázat A 6(H, Me, Bn) és a 112-es vegyületek klórozása

\begin{tabular}{|c|c|c|c|c|c|}
\hline Sor & $\begin{array}{c}\text { Kiindulási } \\
\text { vegyület }\end{array}$ & $\begin{array}{c}\text { Elektrofil } \\
\text { reagens }\end{array}$ & Oldószer & Termék & $\begin{array}{c}\text { Izolált } \\
\text { hozam }(\%)\end{array}$ \\
\hline 1 & $\mathbf{6}(\mathrm{H})$ & NCS $(1$ ekv. $)$ & TFA & $\mathbf{1 3 1}+\mathbf{1 3 2}$ & $16+63$ \\
\hline 2 & $\mathbf{6}(\mathrm{H})$ & NCS $(2$ ekv. $)$ & TFA & $\mathbf{1 3 1}+\mathbf{1 3 2}+\mathbf{1 3 3}$ & $57+19$ \\
\hline 3 & $\mathbf{6}(\mathrm{Me})$ & NCS $(1$ ekv. $)$ & TFA & $\mathbf{1 3 4}+\mathbf{1 3 1}$ & $28+53$ \\
\hline 4 & $\mathbf{6}(\mathrm{Me})$ & NCS $(1$ ekv. $)$ & MeCN + kat. TFA & $\mathbf{1 3 4}+\mathbf{1 3 5}$ & $41+38$ \\
\hline 5 & $\mathbf{6}(\mathrm{Bn})$ & NCS $(1,5$ ekv. $)$ & MeCN + kat. TFA & $\mathbf{1 3 6}+\mathbf{1 3 6}+\mathbf{6 3}$ & $31+32$ \\
\hline 6 & $\mathbf{1 1 2}$ & NCS $(1,5$ ekv. $)$ & MeCN & $\mathbf{1 3 8}+\mathbf{1 3 9}$ & $48+24$ \\
\hline 7 & $\mathbf{1 1 2}$ & NCS $(3$ ekv. $)$ & MeCN & $\mathbf{1 3 8}+\mathbf{1 3 9}+\mathbf{1 4 0}$ & $26+53$ \\
\hline
\end{tabular}

Miután sikeresen megvalósítottuk a különböző halogének A-gyürübe való beépítését, olyan származékok előállítását céloztuk meg, amelyek kétféle halogént tartalmaznak. A halogének eltérő mérete és kémiai viselkedése lehetővé teszi további szelektív átalakítások végrehajtását ezen vegyületekből kiindulva. A különböző halogének jelenléte és helyzete nemcsak a reakciók lefutását, hanem a vegyületek biológiai viselkedését is jelentősen befolyásolhatja. A vegyes halogenideket $(\mathbf{1 4 1}, \mathbf{1 4 2})$ a megfelelő brómvegyületből kiindulva $(\mathbf{1 2 1}, 122)$ a 3.1.1. fejezetben tárgyalt, fenolos hidroxilcsoportot tartalmazó vegyületnél alkalmazott jódozási körülményekkel tudtuk hatékonyan előállítani (48. ábra).

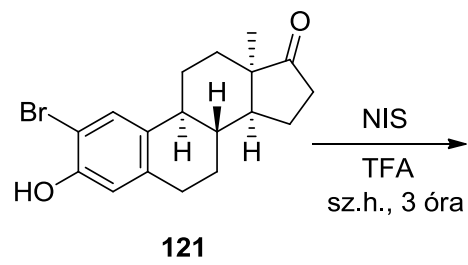<smiles>[14CH3]c1c(O)c(Br)cc(I)c1CI</smiles>

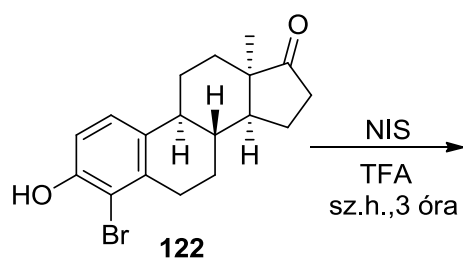<smiles>Oc1c(I)cc(I)c(I)c1Br</smiles>

48. ábra A vegyes halogenidek $(\mathbf{1 4 1}, \mathbf{1 4 2})$ előállítása 
A halogénezési reakciók eredményeit elemezve megállapíthatjuk, hogy az NXS-sel különböző oldószerekben és körülmények között végzett halogénezések hatékonynak

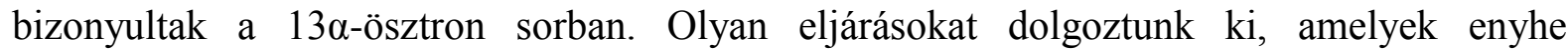
körülmények között, lehetőleg egy lépésben, hatékonyan eredményezik a kívánt halogén

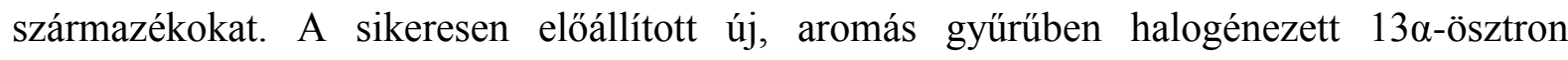
származékok ígéretes alapanyagai lehetnek Pd-katalizált keresztkapcsolási reakcióknak, továbbá potenciális inhibitorai lehetnek az ösztrogének bioszintézisében részt vevő egyes enzimeknek.

$\mathrm{Az}$ újonnan előállított vegyületek mindegyikének szerkezetét ${ }^{1} \mathrm{H}$ - és $\quad{ }^{13} \mathrm{C}-\mathrm{NMR}$ spektroszkópiával igazoltuk. A 49. ábrán a 2-jód- (116) és a 4-jód-3-O-metil-13 $\alpha$-ösztron (117) ${ }^{1}$ H-NMR spektrumai. A két kiemelt részlet az aromás tartományt és a 4-jódszármazék 6- $\mathrm{H}_{2}$ jeleit mutatja. Jellegzetes csúcsok az 1 ppm-nél megjelenő anguláris metilcsoport jele, 3 ppm körül a 3-as metoxicsoport metil-protonjainak hármas intenzitású szingulettje, illetve az aromás régióban az 1-es és a 4-es hidrogének szingulettjei. A harmadik aromás proton jelének hiánya, illetve a meglévő aromás protonjelek alakja utal az A-gyürü ábrán látható szubsztituáltságára. A spektrumon megfigyelhető a két regioizomer egyes proton jeleinek kémiai eltolódás és jelalakbeli különbsége. A 2-halo izomereknél az 1-H és 4-H szingulett jele magasabb kémiai eltolódás értékeknél mutatkozott, míg a 4-halo származékok esetében 8 Hz körüli csatolási állandóval jelentek meg az aromás protonok dublettjei. Az ösztron sorban a 6-os szénatomon található protonok, benzil-helyzetük miatt a többi, alapvázhoz tartozó $\mathrm{CH}_{2}$-nél magasabb kémiai eltolódásnál mutatkoznak. A 4-es regioizomer (117) ${ }^{1} \mathrm{H}-\mathrm{NMR}$ spektrumán (49. ábra, alsó része) a 6- $\mathrm{CH}_{2}$ protonok jelei $2 \mathrm{db}$ multipletté válnak szét. Ez a jelenség minden általunk előállított 4-es pozícióban szubsztituált 13a-ösztron származéknál mutatkozik, így megbízhatóan utal arra hogy az alapváz 4-es szénatomjára szubsztituens épül be. A tapasztaltak sztérikus és/vagy másodrendű kölcsönhatások kialakulásával magyarázhatók a 4-es helyzetű szubsztituens és a 6-os szénatomon levő protonok között. 


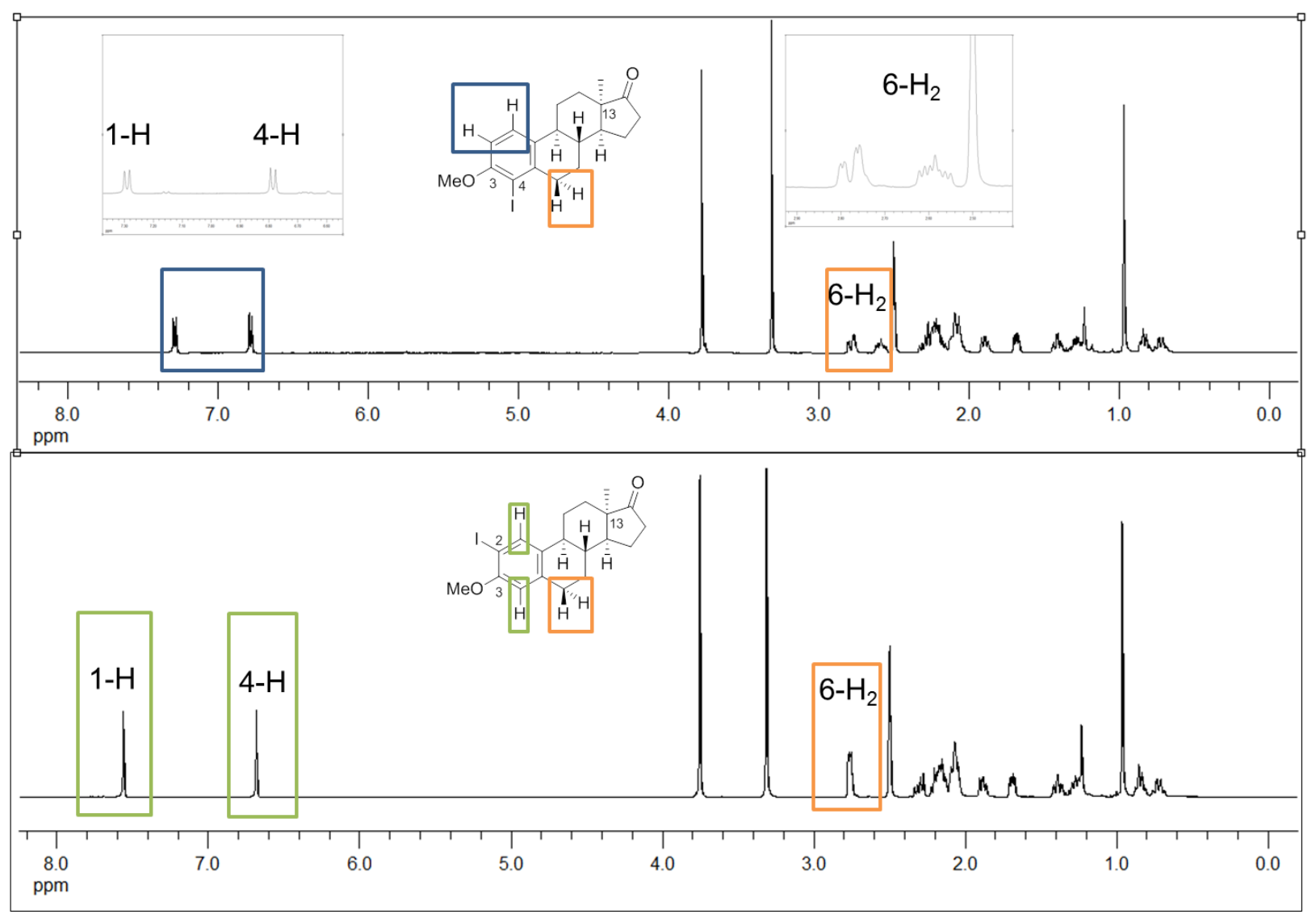

49. ábra A 116- és 117-jelü vegyületek ${ }^{1} \mathrm{H}-\mathrm{NMR}$ spektrumai 


\subsection{Sonogashira keresztkapcsolás A-gyürüben}

A halogénszármazékok birtokában munkánkat Sonogashira keresztkapcsolási reakciókkal folytattuk. A 13a-ösztron származékokat arilhalogenid szubsztrátumként fenil-acetilén reaktánsokkal reagáltattuk. ${ }^{\text {III }}$ Célunk A-gyürüben feniletinil molekularészletet tartalmazó származékok előállítása volt. A természetes ösztron sorban korábban fenil-acetilénnel megvalósított kapcsolást a $13 \alpha$-ösztron sorra kívántuk kiterjeszteni ${ }^{57}$ A Möller és munkatársai által alkalmazott stratégia 3-O-acetil-ösztronból indult ki, és hagyományos melegítéssel játszódott le. Mi védés nélkül, fenolos hidroxilcsoportot tartalmazó szubsztrátumból és hatékonyabb, mikrohullámú eljárással kívántuk célvegyületeinket előállítani. A célból, hogy a biológiai vizsgálatokhoz minél többféle, értékes szerkezet-hatás összefüggést ígérő vegyületet nyerjünk, 3-O-metil származékok átalakításait is terveztük. Ugyanezen megfontolásból nemcsak fenil-acetilénnel, hanem annak szubsztituált származékaival is terveztünk kapcsolásokat. Azt is vizsgálni kívántuk, hogy a szubsztituensek elektronikus sajátságai befolyásolják-e a C-C kapcsolási reakciók lefutását. Külön kihívást jelentett számunkra az alkin funkció kemo- és sztereoszelektív részleges telítése, amelyet transzfer hidrogénezéssel, mikrohullám alkalmazásával terveztünk megvalósítani. Szakirodalmi adatokra alapozva ${ }^{57}$ abból a feltevésből indultunk ki, hogy ilyen típusú átalakításokkal növelhetjük a halogénezett vegyületeink 17ß-HSD1 inhibitor hatását. Vizsgálni kívántuk továbbá, hogy az alkin funkció részleges vagy teljes telítése hogyan befolyásolja a vegyületek enzimhez való affinitását.

Az optimális reakciókörülmények kidolgozásához kiindulási vegyületként a $13 \alpha$-ösztron és 3-metiléterének 2- és 4- jód regioizomereit $(\mathbf{1 1 6}, \mathbf{1 1 7})$ alkalmaztuk. Irodalmi adatok szerint a Sonogashira reakciókban a jódszármazékok reaktívabbak, mint más halogén analógjaik, mivel a jód a legjobb távozó csoport. $^{44}$ Az optimalizálás modell reagenseként a szubsztituálatlan fenil-acetilént (143) választottuk, szteroid komponensként pedig a kevésbé térgátolt 2-es helyzetben szubsztituált izomert (116). Azt tapasztaltuk, hogy a reakciók lefutását nagymértékben befolyásolja a jód pozíciója (50. Ábra). A 2-es helyzetű szénatomra történő kapcsolás esetén az irodalomban széleskörűen használt $\operatorname{Pd}\left(\mathrm{PPh}_{3}\right)_{4}$ katalizátort alkalmaztuk. A reakció DMF-os közegben, mikrohullámú besugárzással, $50^{\circ} \mathrm{C}$-on, 20 perc alatt lejátszódott. Ezt a módszert kívántuk kiterjeszteni a 4-jód vegyületre (117) is. A 4-

\footnotetext{
III Bacsa I., Jójárt R., Wölfling J., Schneider G., Herman B.E., Szécsi M., Mernyák E. Synthesis of novel $13 \alpha$-estrone derivatives by Sonogashira coupling as potential 17 $\beta$-HSD1 inhibitors; Beilstein Journal of Organic Chemistry, 2017, 13, 1303-1309.
} 
fenilalkinil regioizomerek (147) előállításához azonban ez nem bizonyult megfelelőnek. A katalizátort +2-es oxidációs állapotú palládiumot tartalmazó $\operatorname{Pd}\left(\mathrm{PPh}_{3}\right)_{2} \mathrm{Cl}_{2}$ cserélve sikerült előállítanunk a kívánt terméket. Ebben az esetben a reakció magasabb hőmérsékleten, $80{ }^{\circ} \mathrm{C}$ on, és hasonlóan rövid idő alatt (20 perc) játszódott le mikrohullámú reaktorban. A 4-es helyzet sztérikusan gátoltabb a B-gyürü közelsége miatt, ez magyarázhatja az erélyesebb körülmények szükségességét. Az alkalmazott bázis trietil-amin $\left(\mathrm{Et}_{3} \mathrm{~N}\right)$ volt és réz(I)-jodidot (CuI) használtunk segédkatalizátorként mindkét regioizomer esetében. Mindkét esetben előkeverést alkalmaztunk inert atmoszféra alatt a fenil-acetilén reagens hozzáadása elött. Erre azért volt szükség, hogy megakadályozzuk az acetilének $\mathrm{Cu}(\mathrm{I})$-ionok által elősegített dimerizációját, az ún. Glaser típusú kapcsolást. ${ }^{156} \mathrm{Az}$ előkeveréssel nemcsak a melléktermékek képződését kerülhetjük el, hanem a termék hozamát is növelhetjük. A 3-OH jódszármazékok (113, 114) esetében a reakcióközeg megváltoztatására volt szükség, sorrendben a legalkalmasabbak THF és az $\mathrm{CH}_{3} \mathrm{CN}$ voltak. Miután megállapítottuk a legkedvezőbb reakciókörülményeket, végrehajtottuk a keresztkapcsolást különböző $p$ szubsztituált fenil-acetilénekkel (143b-e). A kívánt termékek (144-147) magas hozammal képződtek (50. ábra). Azt tapasztaltuk, hogy a 4'-es helyzetű szubsztituens kémiai minősége nem befolyásolja lényegesen a hozamokat. A fenolos hidroxilcsoport jelenléte nem befolyásolta a kapcsolások lejátszódását, nem volt szükség ennek védésére.

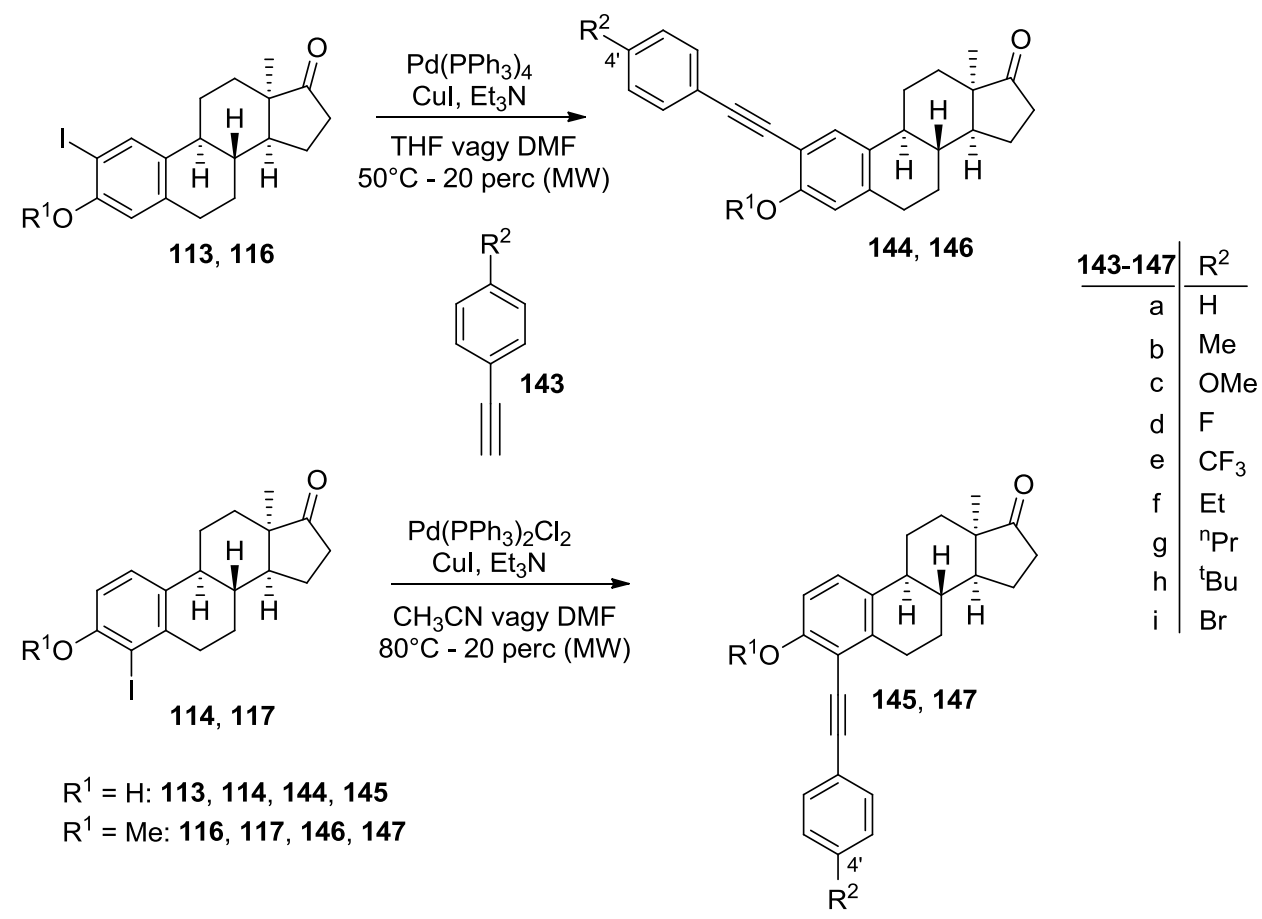

50. ábra 2- vagy 4-fenetinil-13 $\alpha$-öszton származékok (144-147) előállítása Sonogashira kapcsolással 
A kísérletet elvégeztük a jódot és brómot is tartalmazó bisz-halogénszármazékokkal (141, 142) a jód regioizomériájának megfelelő, optimalizált módszerrel. Azt tapasztaltuk, hogy jelen körülmények között kapcsolás nem történik, csupán a jód hasad le. A két különböző halogént tartalmazó diszubsztituált származéknak mindkét esetben csak a monoszubsztituált brómvegyületet tudtuk izolálni a reakcióelegyből.

\subsection{Az alkin funkció részleges és teljes telítése}

Munkánkat a (4'-metoxifenil)etinil származékok (144c-147c) $\mathrm{C} \equiv \mathrm{C}$ kötésének részleges és teljes telítésével folytattuk, a 3-OH és a 3-OMe sorban egyaránt (51. ábra). Azért a 4'metoxi-szubsztituált származékokat választottuk kiindulási anyagként, mert a várt termékek tartalmazzák azt a molekularészletet, amely analóg a rezveratrol (3,5,4'-trihidroxi-stilbén, 51a), metilezett származékával. Ez a vegyület önmagában is jelentős biológiai aktivitással rendelkezik, ezért feltételeztük, hogy a vele szerkezeti hasonlóságot mutató konjugátum szintén ígéretes lehet. A részleges telítést transzfer hidrogénezéssel hajtottuk végre, így irodalmi adatok alapján biztonságosan végezhető el a reakció, magas kemo- és sztereoszelektivitás mellett. $\mathrm{Li}$ módszerét ${ }^{80}$ módosítva, mi $\mathrm{Pd}\left(\mathrm{PPh}_{3}\right)_{2} \mathrm{Cl}_{2}$ katalizátort, hidrogénforrásként $\mathrm{DMF} / \mathrm{KOH}$ rendszert használtunk, és hagyományos melegítés helyett mikrohullámú besugárzást alkalmaztunk. A reakció 35 perc alatt játszódott le. A 146c és a 147c-jelü vegyületek részleges telítését a fent említett módszerrel végeztük, amely kemo- és sztereoszelektíven cisz-alkén (148), valamint transz-alkén (149) származékokat eredményezett (51. ábra). A sztereoszelektivitásra külön figyelmet fordítottunk, mivel az izomertiszta anyagokat szolgáltató módszerek komoly érdeklődésre tarthatnak számot mind kémiai, mind gyógyszerhatástani szempontból. A kapott geometriai izomerek cisz vagy transz jellegét az ${ }^{1} \mathrm{H}-\mathrm{NMR}$ spektrumok alapján számolt vicinális csatolási állandók ismeretében határoztuk meg. Irodalmi adatok szerint a kettős kötésü szénatomokon elhelyezkedő protonok közötti csatolási állandók mértéke megbízhatóan utal a kettős kötés sztereokémiájára ${ }^{157,158}$ 2-es regioizomer (148) ${ }^{1}$ H-NMR spektrumában a kettőskötésü vicinális protonok jelei szingulettként jelentkeznek dupla intenzitással, hasonlóan a 2,4'dimetoxi-stilbén protonjeleihez. A 4-szubsztituált vegyület (149) esetén, az olefin protonok jelei dublettként jelennek meg, nagy, 12,2 Hz-es csatolási állandóval, ami transz orientációra utal. (53. Ábra) Annak magyarázata, hogy a regioizoméria (2- vagy 4-fenetenil származék) 
miért befolyásolja a geometriai izomériát (2-cisz vagy 4-transz izomerek) lehet a 4-es pozíció nagyobb térgátoltsága a B-gyürü közelsége miatt.

Irodalmi ismeretek alapján elemi jód jelenlétében bizonyos $\mathrm{C}=\mathrm{C}$ kötések geometriája megváltoztatható. $^{159}$ A folyamat során feltehetőleg a jód folyamatos asszociációja és disszociációja játszódik le, amely háromtagú gyürüs átmeneti állapoton keresztül lehetőséget nyújt a cisz-transz átmenetre. ${ }^{160}$ A termodinamikai kontroll esetén az energetikailag kedvezőbb, transz izomer irányába tolódik el az egyensúly. Ennek fényében a 2-es cisz (148) és a 4-es transz (149) fenetil származékokat toluol oldószerben katalitikus mennyiségü elemi jóddal vizsgáltuk. Azt tapasztaltuk, hogy szobahőmérsékleten 24 óra alatt a vártnak megfelelően a 2-es cisz regioizomer (148) szinte teljesen átalakul a vegyület transz megfelelőjévé. Azonban a 4-es transz vegyület (149) esetben is tapasztaltunk átalakulást, és ${ }^{1} \mathrm{H}-\mathrm{NMR}$ mérés alapján $E$ és $Z$ izomerek közel 1:3 arányú elegyét kaptuk. A jelenség megoldásának kulcsa az lehet, hogy a 4-es helyzetben valójában mindkét geometria igen térgátolt, ezért a termodinamikai kontroll nem tud olyan mértékben érvényesülni, mint a 2-es regioizomernél.

A részleges telítést a 3-O-metil származékokra optimalizált módszerrel a $144 c$ és a $145 c$ jelű 3-OH vegyületeken is végrehajtottuk (51. ábra). A transzfer hidrogénezés körülményei között a fenolos $\mathrm{OH}$ csoportot tartalmazó származékok esetén egy gyürüzárási reakciót figyeltünk meg, amely benzofuránokat $(\mathbf{1 5 0}, \mathbf{1 5 1})$ eredményezett. A gyürüzárás formailag egy $\mathrm{C} \equiv \mathrm{C}$ kötésre történő addíciós reakciónak tekinthető, mivel a hozzáadott bázis következtében a fenolos $\mathrm{OH}$ csoport oxigénje nukleofil támadást indít az egyik hármas kötésű szénatomra (a Pd jelenléte elősegíti ezt a folyamatot), a másik szénatom pedig hidrogént vesz fel. Részlegesen telített 3-OH vegyületeket tehát ezzel a módszerrel nem sikerült előállítanunk. Annak ellenére, hogy nem a céltermékhez jutottunk, a benzo[b]furán molekularészletet tartalmazó új vegyület is hordozhat értékes biológiai aktivitást. 


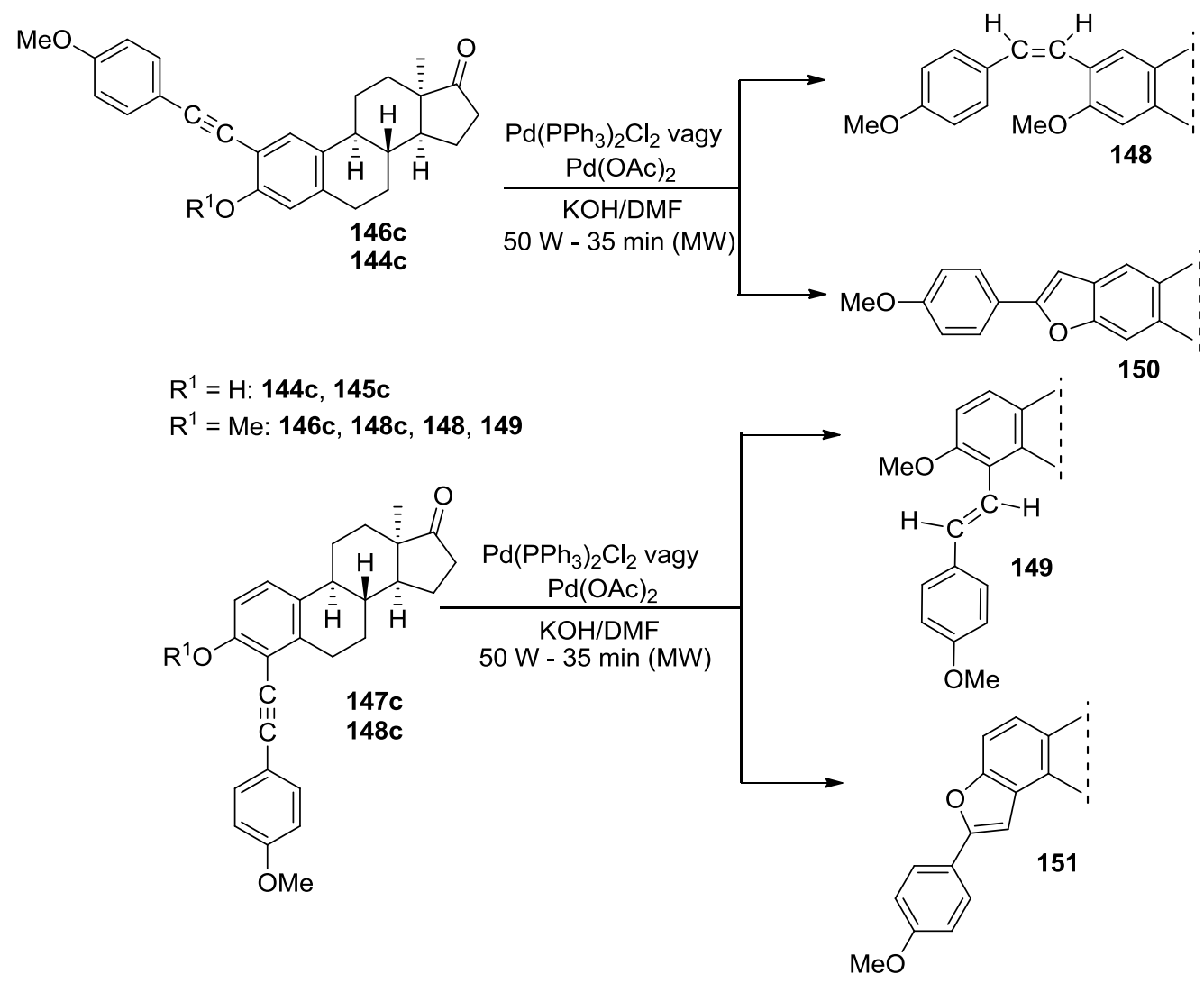

51. ábra A 144c-147c vegyületek részleges hidrogénezése

A 2- vagy 4-fenetinil származékok $(\mathbf{1 4 4 c - 1 4 7 c )}$ teljes telítése $\mathrm{Pd} / \mathrm{C}$ jelenlétében, etil-acetátos (EtOAc) közegben, 20 bar hidrogén nyomás alatt, szobahőmérsékleten játszódott le (52. ábra). A (4'-metoxifenil)etil származékok (44-47) gyorsan, magas hozammal képződtek.

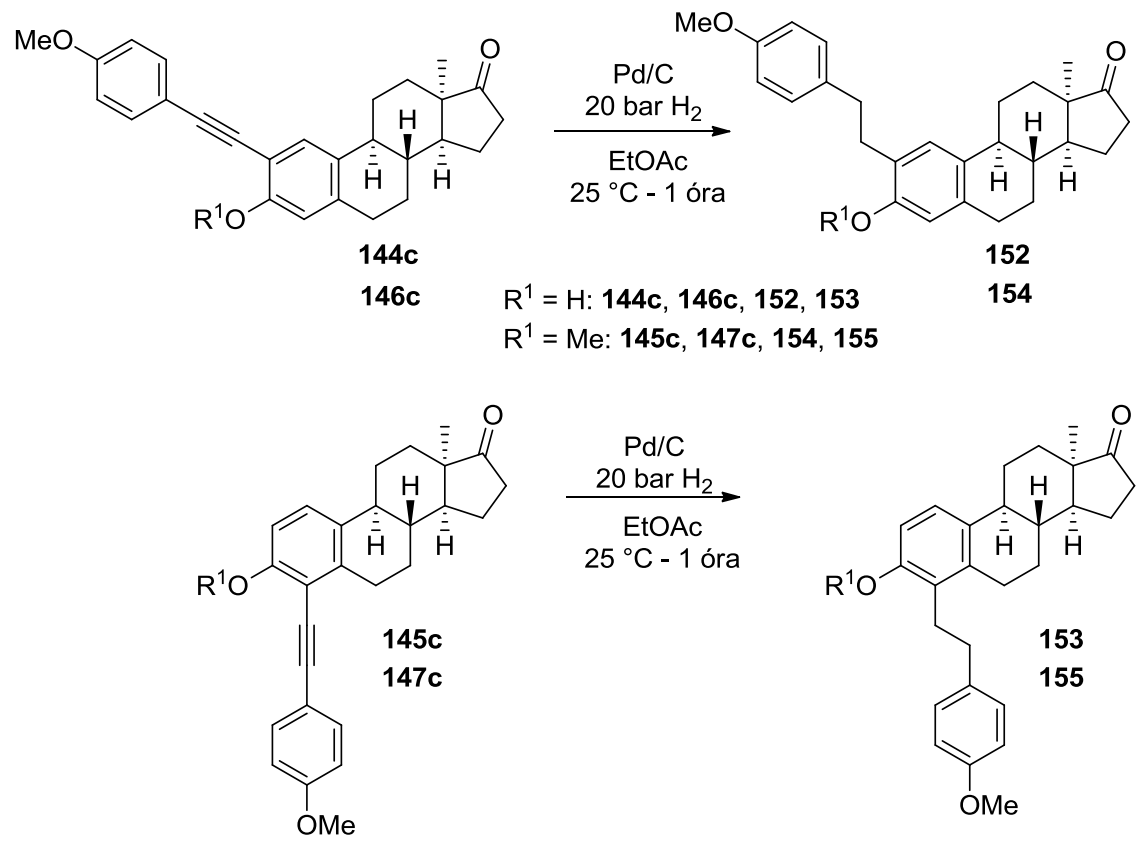

52. ábra A 144c-147c vegyületek teljes hidrogénezése 
Az újonnan előállított Sonogashira kapcsolt vegyületek (144-147) szerkezetét ${ }^{1} \mathrm{H}$ - és ${ }^{13} \mathrm{C}$ NMR-spektroszkópiával igazoltuk. A 3-metiléter sorba tartozó 4-jód regioizomer (117), a 4es helyzetben $p$-metoxifenil csoportot tartalmazó származék (145c), és annak részleges (149), valamint teljesen telített (155) analógjainak ${ }^{1} \mathrm{H}-\mathrm{NMR}$ spektrumait az 53. ábra mutatja. A spektrumokon jól követhetőek a vegyületek kémiai módosításaihoz köthető változások. A 4(4'-metoxifenil)etinil (145c) származék esetén az aromás tartományban szembetűnőek az újonnan beépített aromás gyürü protonjainak jelei a 4-jód regioizomer (117) spektrumához képest. A 145c-jelü vegyület aromás A-gyürüjének protonjai 6,83 és 7,26 ppm-nél jelennek meg, dublettjei 8,8 Hz-es csatolási állandóval rendelkeznek. A feniletenil (149) származék esetében jól láthatók a vinil protonok dublettjei 6,30 és 6,61 ppm-nél, 12,2 Hz csatolási állandóval, ami transz orientációra utal. A feniletil regioizomer (155) esetében eltűntek a kettős kötésű protonok jelei, és az újonnan beépített aromás gyürü protonjainak multiplettjei alacsonyabb kémiai eltolódásnál jelentkeznek, utalva a kémiai változásra. 


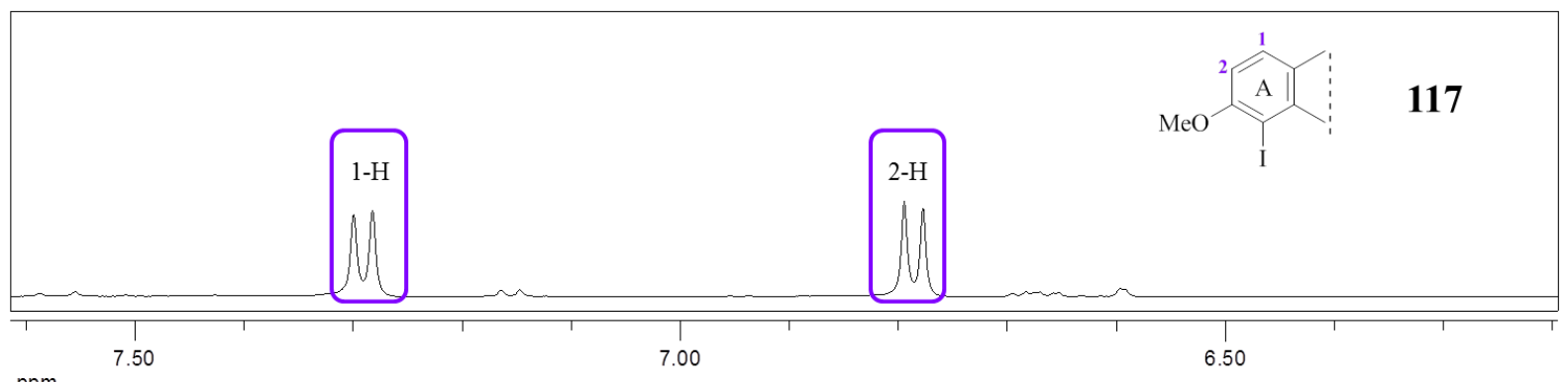

ppm

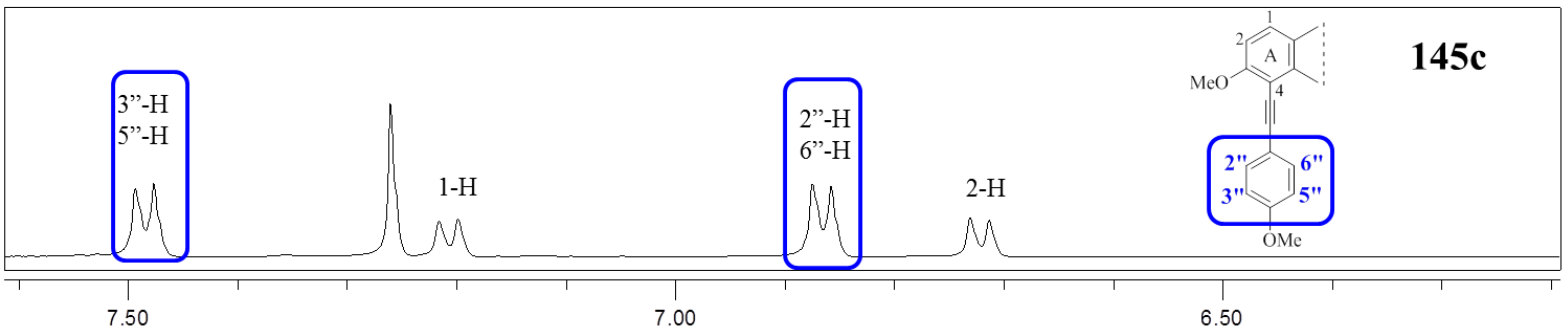

$\mathrm{ppm}$

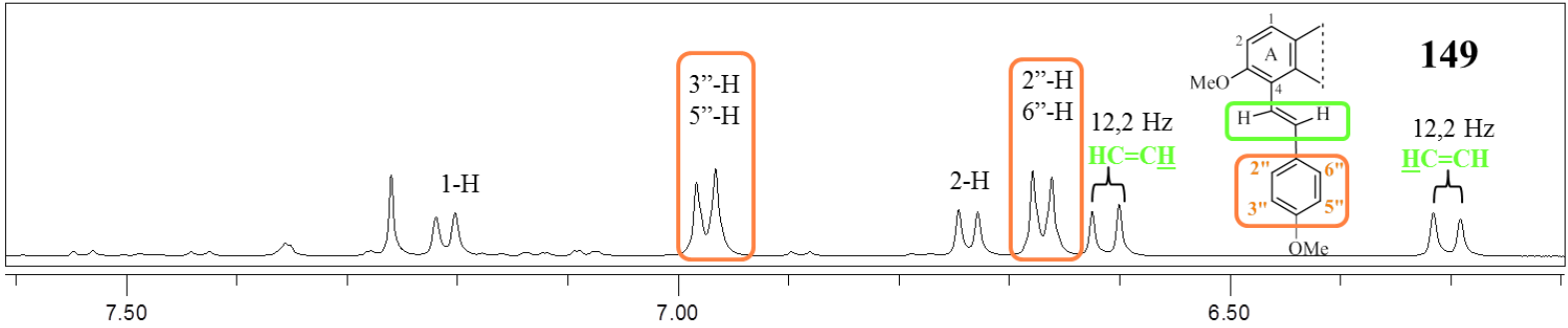

$\mathrm{ppm}$

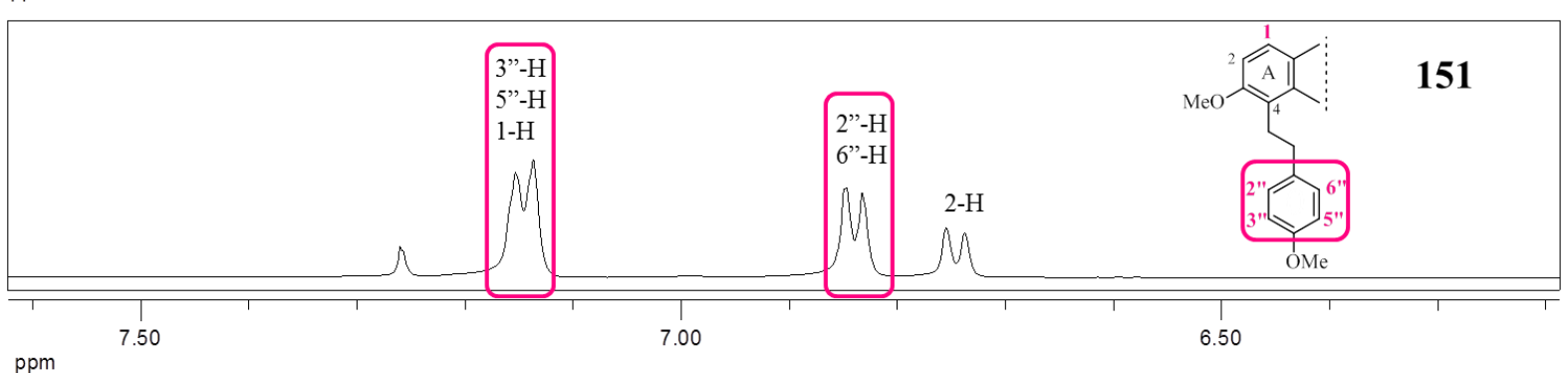

$\mathrm{ppm}$

53. ábra A 117-, a 145c-, a 149- és a 151-jelű vegyületek ${ }^{1} \mathrm{H}-\mathrm{NMR}$ spektrumai

A 145c-, a 149- és a 151-jelü vegyületek ${ }^{13} \mathrm{C}-\mathrm{NMR} \mathrm{J}$-mod (csatolási állandó modulált) spektrumainak 50-170 ppm közötti tartományát az 54. ábra mutatja, melyeken jól követhetőek a szerkezeti változások. A feniletinil származék (145c) kvaterner $\mathrm{C} \equiv \mathrm{C}$ jelei 80 és 100 ppm között láthatók, a spektrum alsó régiójában. A részlegesen telített származék (149) $\mathrm{HC}=\mathrm{CH}$ csoportjának jelei jellemzően magasabb eltolódásnál, 153,3 ppm és 130,9 ppm-nél mutatkoznak, a tercier szénatomok jelei a spektrum felső régiójában láthatók. Mindezek igazolják a kémiai átalakítások sikerességét. A teljesen telített származék (151) esetében alacsonyabb eltolódásnál, 50 ppm alatt jelennek meg a $\mathrm{C}=\mathrm{C}$ telítésével nyert szekunder $\mathrm{CH}_{2}$ szénatomok jelei. Az aromás régióban (110-175 ppm) továbbra is megtalálhatók az arra jellemző értékek. 

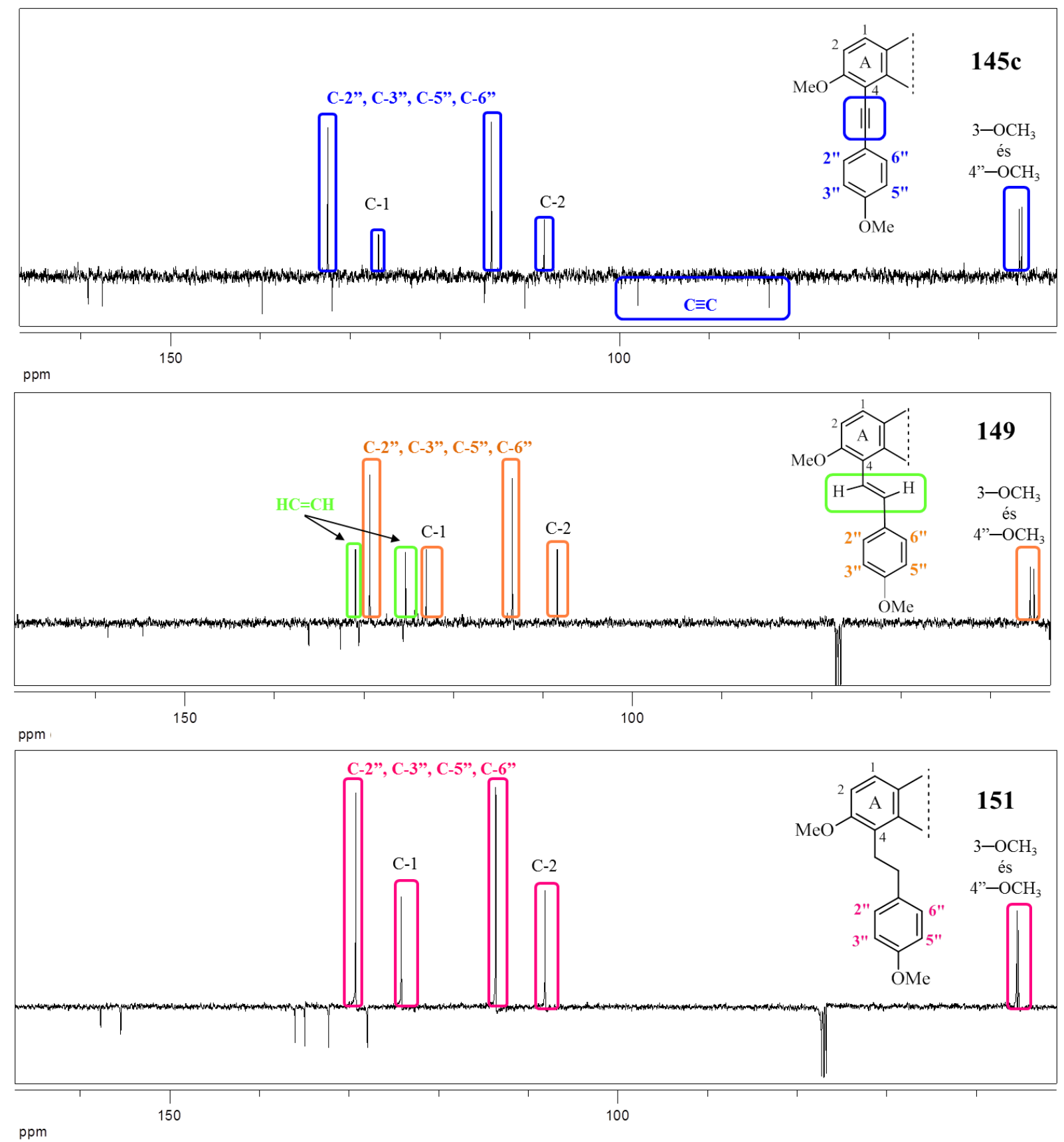

54. ábra A 145c-, a 149- és a 151-jelü vegyületek ${ }^{13} \mathrm{C}-\mathrm{NMR}$ csatolási állandó modulált (J-mod) spektrumai 


\subsection{Buchwald Hartwig kapcsolás}

Kísérleti munkánk folytatásában, a Pd-katalizált reakciók körében áttértünk a C-N keresztkapcsolási B-H típusú reakciókra. ${ }^{\text {IV }}$ A $13 \alpha$-ösztrán vázat alapul véve olyan aminálási eljárás kidolgozása volt a célunk, amely hatékonyan, rövid reakcióidővel szolgáltatja az aminoszteroidokat. Olyan reakciók végrehajtását terveztük, amelyek arilbromid szubsztrátuma 2-es vagy 4-es helyzetben halogénezett 13 $\alpha$-ösztron, reagense pedig valamilyen amin, elsősorban anilin. A C-N kapcsolás megvalósítása nemcsak szerves kémiai, hanem gyógyszerkémiai szempontból is kihívást jelentett, ugyanis az aminoösztronok ígéretes biológiai hatást hordozhatnak. Az előző fejezetben tárgyalt C-C kapcsolási reakciókkal jelen téma szorosan összefügg, mivel a 13 $\alpha$-ösztrán vázhoz korábban két szénatomos linkeren keresztül kapcsolt lipofil fenilcsoport jelenléte kedvező volt a vegyületek enzimgátlási potenciálja szempontjából [1s. 3.6. fejezet]. Megállapítottuk, hogy a rövid linker szénatomainak hibridállapota nem befolyásolja a biológiai hatást. Ehhez kapcsolódóan fontosnak tartottuk olyan vegyületek előállítását, amelyek amino-linkeren keresztül tartalmazzák a lipofil fenilcsoportot. Választásunkat szakirodalmi ismereteinkre alapoztuk, amelyek szerint az ösztron A-gyürüjének nagyméretű lipofil-jellegű csoporttal való irányított szubsztituálásával nyert származékok hatékony 17ß-HSD1 gátlók, egyben tumorellenes hatóanyagok. ${ }^{57}$ Kísérleteink sorát a 2-bróm-3-O-metil-13 $\alpha$-ösztron anilinnel (156) való reakcióival kezdtük (4. Táblázat fejléce). Ismeretesek ugyanis arilbromidokkal és jodidokkal végzett B-H kapcsolások is, amelyek a halogén minőségétől függetlenül, közel azonos hozammal szolgáltatják a termékeket annak ellenére, hogy a jodid jobb távozó csoport, mint a bromid. A folyamat mechanizmusára vonatkozóan egyenlöre csupán feltételezések vannak, és a tapasztalati szabályok alapján nem egyértelmü, hogy a legjobb távozó csoport alkalmazása szükséges-e a hatékonysághoz. A 13 $\alpha$-ösztron $(6(H))$ aromás Agyürüje aromás elektrofil szubsztitúcióban aktiváló és $o-, p$-irányító fenolos hidroxilcsoportot tartalmaz, amelynek a bróm mellett való elhelyezkedése hátrányos lehet az aminálási reakció szempontjából. Az OH-csoport elektronikus sajátságai és a fenol molekularészlet viszonylag nagy reaktivitása mellékreakciók lejátszódásához vezethetnek, ahogyan azt korábban a C-C keresztkapcsolási reakcióknál is tapasztaltuk (3.2.). Ezek elkerülése érdekében választottuk a 3-as helyzetben kisméretü éter funkcióval ellátott kiindulási vegyületet (124). A metoxicsoport sztérikus gátlása nem számottevő, és az várhatóan az alkalmazott kísérleti

\footnotetext{
IV Bacsa I., Szemerédi D., Wölfling J., Schneider G., Fekete L., Mernyák E. The first Pd-catalysed Buchwald-Hartwig aminations at C-2 or C-4 in the estrone series; Beilstein Journal of Organic Chemistry, 2018, közlésre elfogadva
} 
körülmények között nem hasad le. Az irodalmi elözményekben tárgyaltakra alapozva, az optimalizálás során három kísérleti körülményt változtattunk szisztematikusan: a Pd forrást, a ligandumot és az alkalmazott bázist. A szakirodalom alapján mindhárom komponens meghatározó a reakció sikeres kimenetelének érdekében.

A 4. táblázat szemlélteti az alkalmazott reakciókörülményeket. A Pd forrásnak meghatározó szerepe van az aminálási lépésben, ezért két különböző katalizátort is kipróbáltunk az optimalizációs reakciókban. Választásunk a $\mathrm{Pd}+2$-es oxidációs állapotú sójára, a $\mathrm{Pd}(\mathrm{OAc})_{2}-$ ra (4. táblázat, 1-10. sor) és a $\mathrm{Pd}_{2}(\mathrm{dba})_{3}$-ra esett, (4. táblázat, 11-18. sor) amelyben a fém (0) oxidációs állapotú. A kapcsolási reakciókat két foszfán ligandum, a kisebb térkitöltésü XPhos (4. táblázat, 1-6., 11-14. sor) vagy a térgátoltabb BINAP (4. táblázat, 7-10, 15-18. sor) jelenlétében végeztük. Bázisként a szerves DBU-t (4. táblázat, 1, 7, 11, 15. Sor), a szervetlen $\mathrm{Cs}_{2} \mathrm{CO}_{3}$-ot (4. táblázat, $6,10,14,18$. sor) vagy az erősen bázikus $\mathrm{KO}^{t} \mathrm{Bu}$-ot (4. táblázat, 2, 3, $8,12,16$. sor) vagy $\mathrm{NaO}^{t} \mathrm{Bu}$-ot (4. táblázat, 4, 5, 9, 13, 17. sor) alkalmaztuk. A toluol oldószert korábbi ösztron sorban tárgyalt irodalmi előzmények ${ }^{117}$ alapján választottuk. A reakcióelegyeket az arilhalogenid nélkül, $60^{\circ} \mathrm{C}$-on, 5 percig elömelegítettük, majd $150^{\circ} \mathrm{C}$-on MW reaktorban reagáltattuk 20 percig. A reakciók lejátszódását vékonyréteg kromatográfiásan követtük. A reakciók kimenetele nagymértékben függött a Pdkatalizátortól, az alkalmazott ligandumtól és a bázistól. A célvegyület 2-fenilamino-3-Ometil-13 $\alpha$-ösztron (157) $\operatorname{Pd}(\mathrm{OAc})_{2}$ katalizátor jelenlétében (4. Táblázat, 1-10. sor) az egyéb körülményektől függően változó hozamokkal képződött. Kivételt ez alól a $\mathrm{Cs}_{2} \mathrm{CO}_{3}$ bázis alkalmazása jelentette, mely során csupán dehalogéneződést figyeltünk meg, 20-60\%-os hozammal. A $\mathrm{NaO}^{t} \mathrm{Bu}$ vagy $\mathrm{KO}^{t} \mathrm{Bu}$ alkalmazása (4. Táblázat, 2, 4. és 8 , 9. Sor) alkalmazása előnyösebbnek bizonyult a DBU-nál (4. Táblázat, 1. és 7. sor). A ligandum tekintetében az XPhos-al magasabb hozamok voltak elérhetőek, mint a BINAP-pal. A $\mathrm{Pd}_{2}(\mathrm{dba})_{3}$ alkalmazása a várakozásunkkal ellentétben nem volt sikeres, egyetlen kombinációban sem szolgáltatta kielégítően az 157-jelü célterméket. Ilyen körülmények között csupán $\mathrm{NaO}^{t} \mathrm{Bu}$-tal és $\mathrm{KO}^{t} \mathrm{Bu}$ tal volt megfigyelhető az 157 képződése, de alacsony hozamokkal (4. Táblázat, 12, 13, 16, 17). A kiindulási halogénvegyület (124) nagyrészt visszanyerhető volt, sem dehalogéneződést, sem $\mathrm{C}\left(\mathrm{sp}^{2}\right)-\mathrm{N}$ kapcsolási reakciót nem figyeltünk meg. Az optimális reakciókörülmények megállapítása után (4. Táblázat, 3. sor), a dehalogéneződési mellékreakció elkerülése érdekében a hőmérsékletet $100^{\circ} \mathrm{C}$-ra csökkentettük (4. Táblázat, 4. sor). A reakció hatékonysága a magasabb hőmérsékletnél tapasztalthoz képest nem romlott, sőt enyhe javulás történt az összhozamban. Összehasonlító vizsgálatok céljából egymással 
párhuzamosan hagyományos és mikrohullámú melegítéssel is végrehajtottuk a reakciókat. Ennek során azt tapasztaltuk, hogy a mikrohullámú technika alkalmazása a hozamokat nem befolyásolta számottevően, azonban a reakcióidőben jelentős csökkenést értünk el (10 perc vs. 24 h). A további átalakításokhoz ezért a mikrohullámú módszert alkalmaztuk.

4. táblázat Az optimalizálás körülményei ${ }^{\mathrm{a}}$

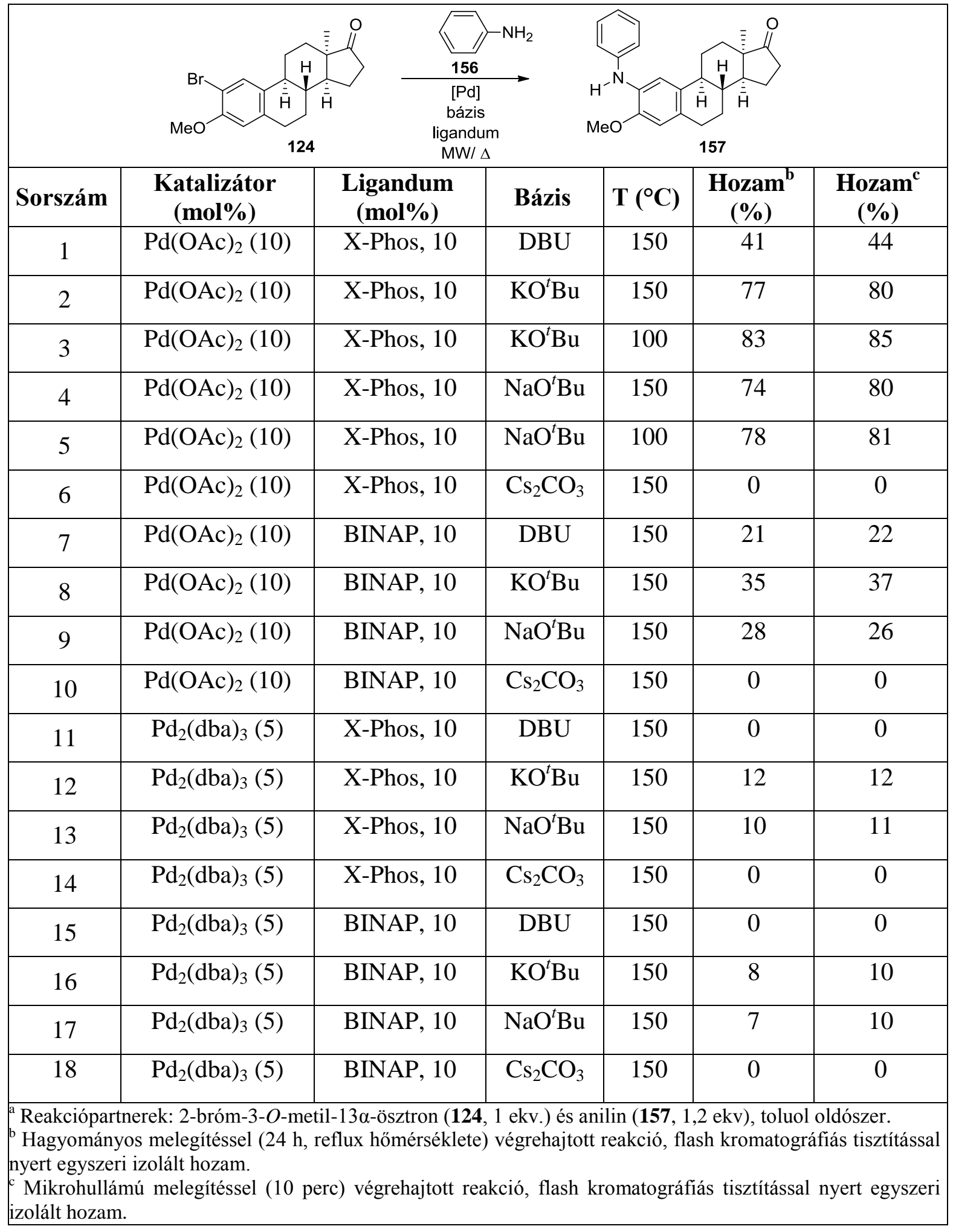


Az optimális körülmények birtokában, az anilinre kidolgozott módszert kiterjesztettük különböző elektronikus tulajdonságú orto, meta és para szubsztituenssel rendelkező monoszubsztituált anilinekre is. (55. ábra; 5. Táblázat, 1-13. Sor). Az 5. táblázatban látható, hogy a kívánt vegyületeket (158-160) magas hozamokkal nyertük. A legmagasabb hozamokat a nitroanilinekkel sikerült elérni, az elektronszívó nitrocsoport helyzetére való tekintet nélkül (5. Táblázat, 11-13. Sor). Ezzel szemben az elektrondonor metilcsoport jelenléte (5. Táblázat, 2-4. Sor) nem volt kedvező a reakció lejátszódásának szempontjából. Azt tapasztaltuk, hogy a meta helyzetű szubsztituens enyhén csökkentette a hozamot az orto és para helyzetü szubsztituenshez képest, azonban számottevő befolyása nem volt az összhozamra.
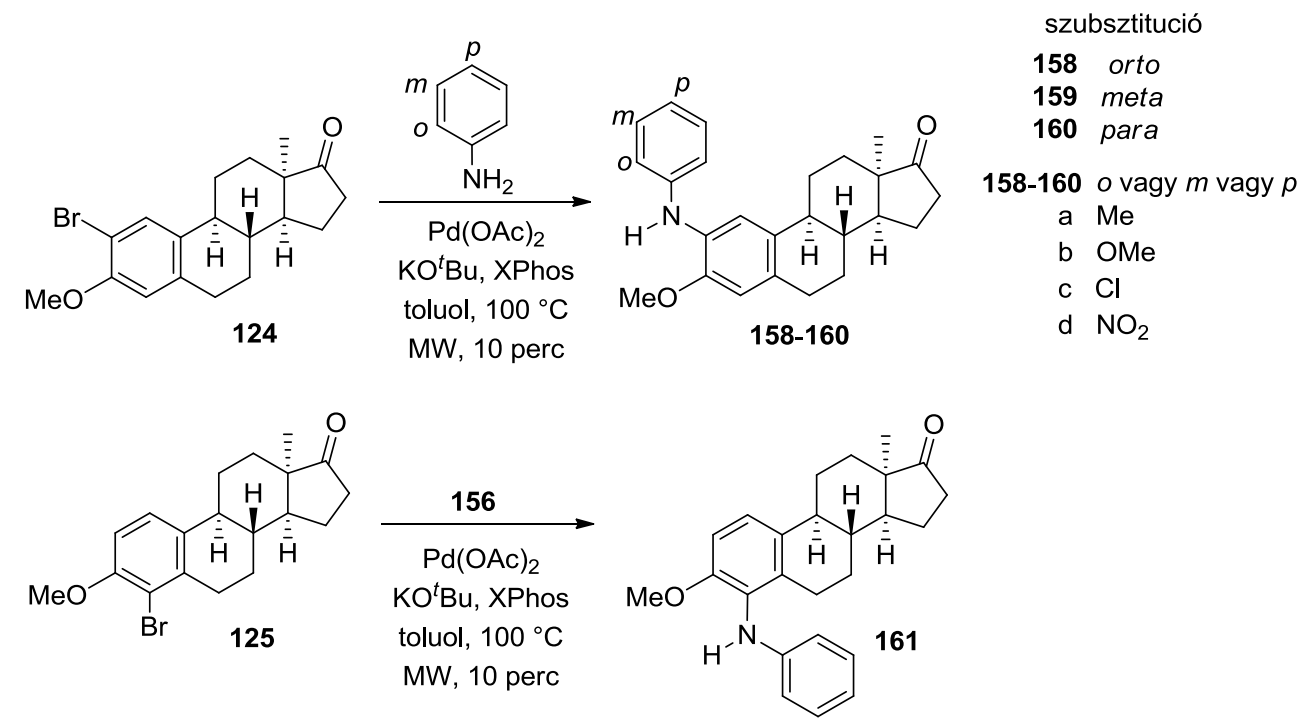

55. ábra Az optimalizált módszer kiterjesztése különbözőképpen szubsztituált anilinekkel történő kapcsolásra (felső) és 4-bróm-3-O-metil-13 $\alpha$-ösztronra (125) (alsó) 
5. táblázat B-H aminálás monoszubsztituált anilin származékokkal és különböző szteroidokkal (125-127) ${ }^{\mathrm{a}}$

\begin{tabular}{|c|c|c|c|c|}
\hline Sor & Szteroid & Anilin & Termék & $\operatorname{Hozam}^{\mathrm{b}}(\%)$ \\
\hline 1 & \multirow{13}{*}{124} & $\mathrm{H}$ & 157 & 85 \\
\hline 2 & & $o-\mathrm{Me}$ & $158 \mathrm{a}$ & 80 \\
\hline 3 & & $m-\mathrm{Me}$ & 159a & 79 \\
\hline 4 & & $p-\mathrm{Me}$ & $160 a$ & 81 \\
\hline 5 & & $o$-OMe & $158 \mathrm{~b}$ & 94 \\
\hline 6 & & $m$-OMe & $159 \mathrm{~b}$ & 92 \\
\hline 7 & & $p$-OMe & $160 \mathrm{~b}$ & 94 \\
\hline 8 & & $o-\mathrm{Cl}$ & $158 \mathrm{c}$ & 87 \\
\hline 9 & & $m-\mathrm{Cl}$ & $159 \mathrm{c}$ & 84 \\
\hline 10 & & $p-\mathrm{Cl}$ & 160c & 87 \\
\hline 11 & & $o-\mathrm{NO}_{2}$ & 158d & 96 \\
\hline 12 & & $m-\mathrm{NO}_{2}$ & 159d & 93 \\
\hline 13 & & $p-\mathrm{NO}_{2}$ & 160d & 95 \\
\hline 14 & 126 & $\mathrm{H}$ & 162 & 86 \\
\hline 15 & 125 & $\mathrm{H}$ & 161 & 85 \\
\hline 16 & 127 & $\mathrm{H}$ & 163 & 84 \\
\hline
\end{tabular}

Annak tanulmányozására, hogy az arilbromid regioizomériája befolyásolja-e a B-H aminálás lefutását, modellkísérletként a 4-bróm-3-O-metil-13 $\alpha$-ösztron (125) anilinnel való reakcióját választottuk (55. ábra). Azt tapasztaltuk, hogy a 2- és a 4-bróm származékból $(\mathbf{1 2 4}, \mathbf{1 2 5})$ ugyanazon reakciókörülmények között hasonló hozammal képződtek a várt termékek. A bróm ösztrán vázon való eltérő elhelyezkedése nem befolyásolta sem a reakció kemoszelektivitását, sem a hozamot (5. Táblázat 1. Sor v.ö.: 14. sor). Korábban, a Sonogashira kapcsolásoknál megállapítottuk, hogy a sztérikusan gátoltabb 4-es pozícióban való kapcsolás erélyesebb körülményeket igényel (3.2 fejezet). Jelen aminálási folyamatokban nem figyeltünk meg ilyen különbséget. Kísérleteink sorát a 3-benziléter (3c) átalakításaival folytattuk. Vizsgálni kívántuk az általunk metiléterekre kidolgozott $\mathrm{C}\left(\mathrm{sp}^{2}\right)-\mathrm{N}$ kapcsolási eljárás 3-benziléterekre való kiterjeszthetőségét (56. ábra). Azt vártuk, hogy a 
nagyobb térkitöltésű védőcsoportot tartalmazó szteroid hatékony aminálásához erélyesebb körülmények szükségesek, különösen a 4-es regioizomer esetében. Feltételeztük, hogy a 3-Obenzil-4-bróm származék (4c) 4-es pozícióban a B-gyürű közelsége miatt nehezebben kapcsolható anilinnel. Az 57. ábra mutatja a két bróm regioizomer 3-benziléter Chem3D programmal energiaminimalizált szerkezetét. Az ábra jól tükrözi, hogy a 4-es szénatom sokkal kevésbé hozzáférhető, mint a 2-bróm származék (3c) 2-es szénatomja. A benziléterek anilinnel való aminálása során azonban azt tapasztaltuk, hogy a várttal ellentétben mindkét regioizomer brómvegyület aminálása jó hozammal játszódott le (5. Táblázat, 14., 16. Sor). Ez alapján arra a következtetésre jutottunk, hogy az általunk kidolgozott módszer alkalmas lehet sztérikusan gátolt szubsztrátumok Pd-katalizált aminálására is.
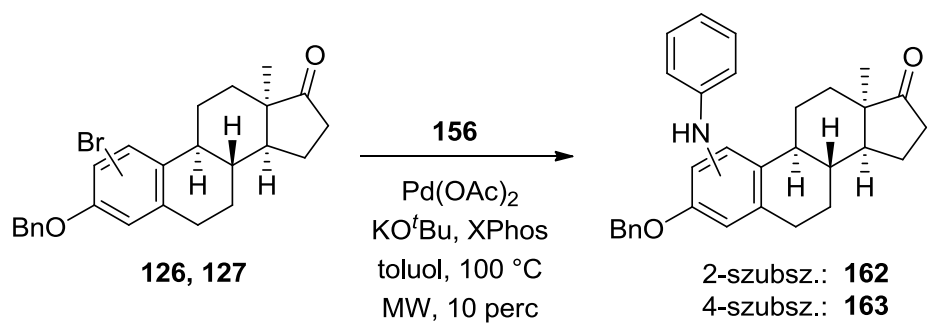

56. ábra A 3-benziléter brómvegyületek $(\mathbf{1 2 6}, \mathbf{1 2 7})$ B-H kapcsolása

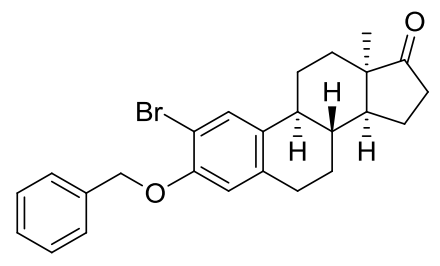

126

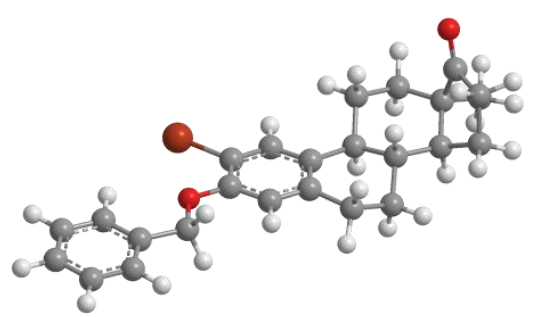

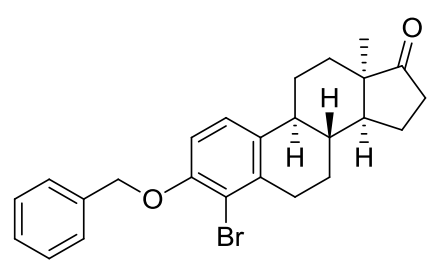

127

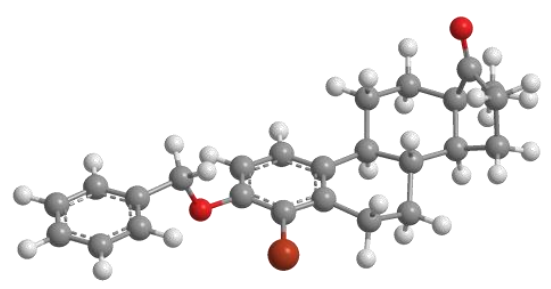

57. ábra A 126- és 127-jelű vegyületek energiaminimalizált modellje

Munkánk folytatásában az A-gyürüben 2-es vagy 4-es szénatomján aminocsoportot tartalmazó 13 $\alpha$-ösztron előállítását céljából amin reakciópartnerként a benzofenon-imint választottuk. Az általunk anilinekre kidolgozott módszer sikeresen alkalmazható volt benzofenon-iminnel, mint amin prekurzorral való kapcsolásra is. Mindkét regioizomer 
brómvegyület, függetlenül az éter funkció térkitöltésétől készségesen reagált a benzofenoniminnel (58. Ábra). A várt termékek (164-166) magas hozammal képződtek. Az Ndifenilmetilidénamino-csoport lehasítása a 3-metiléterek $(\mathbf{1 6 4}, \mathbf{1 6 5})$ esetében sósavval, mint erős Brønsted savval gyorsan végbement (58. ábra). Így olyan 2- vagy 4-amino-13 $\alpha$-ösztron származékokhoz jutottunk (167, 168), amelyek $O$-metilcsoportot tartalmaznak a 3-as helyzetben. Olyan aminoösztron elöállítását is terveztük, amely fenolos hidroxilcsoportot tartalmaz. Ennek megvalósításához a 3-benziléter származékot (126) választottuk alapul. A benziléter kapcsolásával nyert vegyület (166) 2-es és 3-as helyzetben olyan csoportokat tartalmaz ( $N$-difenilmetilidénamino és benzil), amelyek hasonló reakciókörülmény alkalmazásával egyszerre távolíthatók el. Az amino- és a hidroxilcsoport felszabadítására lehetőséget nyújt a savas kezelés vagy a Pd-katalizált hidrogenolízis is, mi ez utóbbit választottuk célunk eléréséhez. A 166-os jelü származékból Pd/C katalizátor segítségével, hidrogenolízissel egy lépésben lehasítottuk a benziléter védőcsoportot és felszabadítottuk az amint (169). Sikerült tehát egy olyan kétlépéses eljárást kidolgoznunk, amely az arilhalogenidből két lépésben szolgáltatja a kívánt aminocsoportot tartalmazó származékot anélkül, hogy egy további lépést beiktatására lenne szükség a fenolos hidroxilcsoport védőcsoportjának eltávolításához. Az újonnan szintetizált 13a-aminoösztronok önmagukban is értékes farmakológiai hatásokat hordozhatnak, vagy hasznos intermedierek lehetnek további aminocsoporton szubsztituált származékok szintéziséhez.
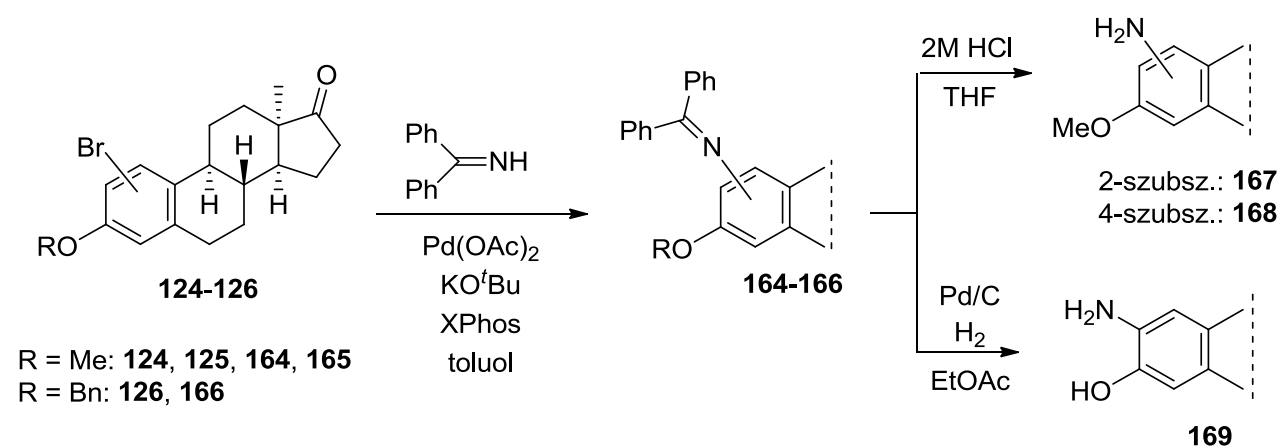

58. ábra 2- $(\mathbf{1 6 7}, \mathbf{1 6 9})$ és 4-amino-13 $\alpha$-ösztron (168) származékok előállítása B-H aminálással

Az újonnan elöállított vegyületek mindegyikének szerkezetét ${ }^{1} \mathrm{H},{ }^{13} \mathrm{C}, \mathrm{HSQC}$ és/vagy HMBC NMR mérésekkel igazoltuk. A 59. ábrán látható a 2-bróm-3-O-metil-13 $\alpha$-ösztron (124), valamint a 2-fenilamino származék (157) ${ }^{1} \mathrm{H}-\mathrm{NMR}$ spektrumainak részlete. Az utóbbi spektrum aromás régiójának pirossal kiemelt részletét a kiindulási brómvegyület azonos 
tartományával összevetve jól látható a szubsztituens beépülése a molekulába. A kiindulási vegyület aromás protonjai (4-H és 1-H) mellett az aromás régióban 6,69-nél megjelenik jelalak és intenzitás alapján a 4'-H, valamint 6,88 és 7,13 ppm-nél mutatkoznak a beépült fenilcsoport aromás protonjainak (2'-H, 3'-H, 5'-H és 6'-H) jelei. Az NH proton jele egybeesik az aromás protonok valamelyikével.

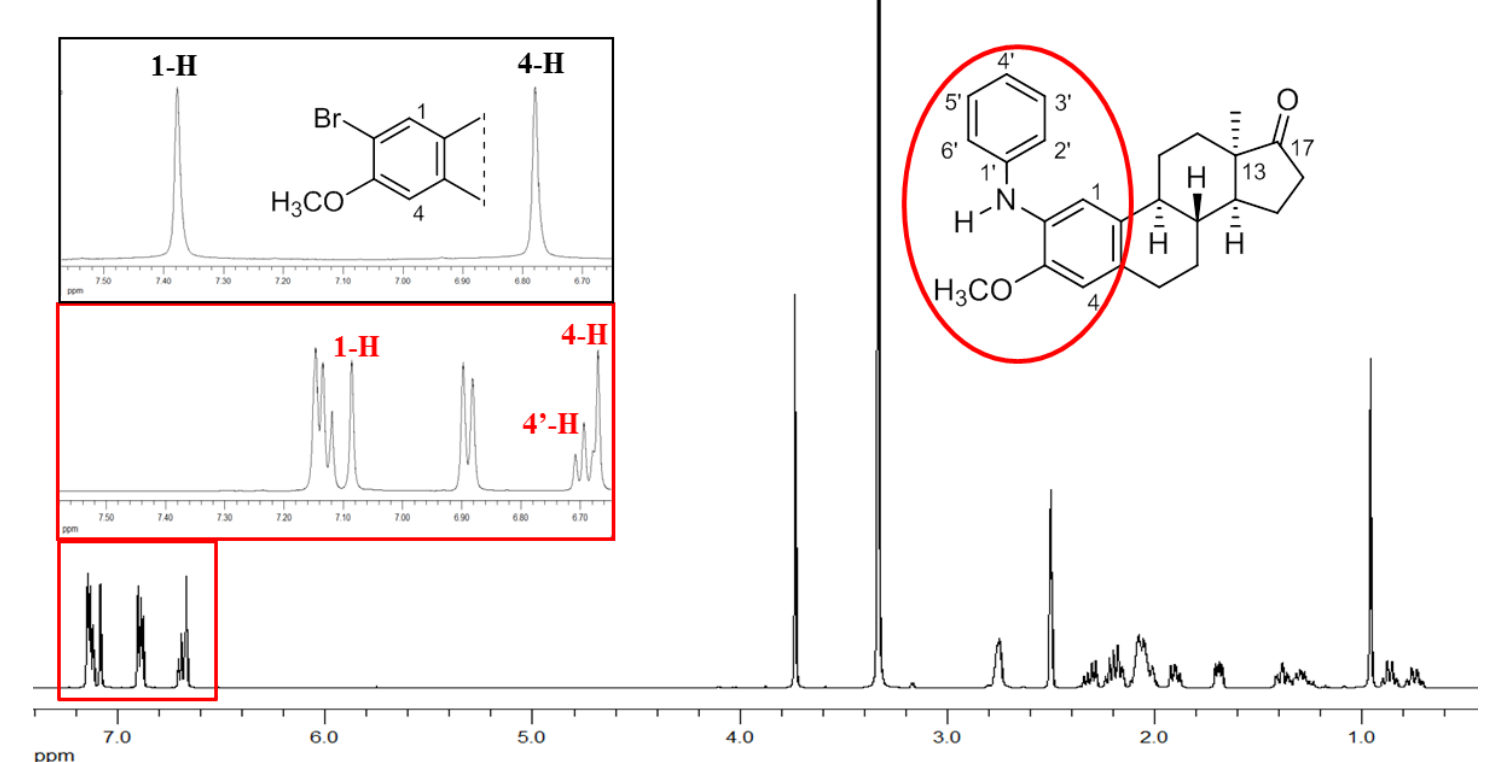

59. ábra A 2-fenilamino származék (157) és előanyagának (124) ${ }^{1} \mathrm{H}$ NMR spektum részletei

$\mathrm{A}{ }^{13} \mathrm{C}$ spektumban is megfigyeltük az újonnan beépült fenilcsoport aromás szénatomjaihoz tartozó jeleket.Az újonnan beépült fenilcsoport proton- és szénatomjai jeleinek egyértelmű hozzárendelés céljából azonban szükség volt az új vegyületek (157, 158-160) kétdimenziós HSQC és HMBC NMR spektumainak felvételére is. Az 61. ábrán a 2-fenilamino-13 $\alpha$-ösztron (157) HSQC és HMBC NMR spektrumainak kiemelt részletei láthatók, amelyeken keresztül ismertetem az így nyerhető legfontosabb szerkezeti információkat. A HSQC spektrum megerősítette a feltételezésünket, hogy az NH proton jele a legmagasabb kémiai eltolódású, hármas intenzitású multiplett része, ugyanis a multiplett csak egy dupla intenzitású aromás tartományban jelentkező szén jellel ad keresztcsúcsot. Az NH jel kémiai eltolódásának ismeretében a HMBC spektrumból be tudtuk azonosítani, hogy 115,4 ppm-nél a C-2',6', míg 128,8 ppm-nél a C-3',5’ tercier szenek jelei találhatók. Az új információk birtokában már a többi aromás jelet (C-4' - 118,3; C-1' - 144,8; C-3 - 148,6) is hozzá tudtuk rendelni a megfelelö aromás maghoz. 


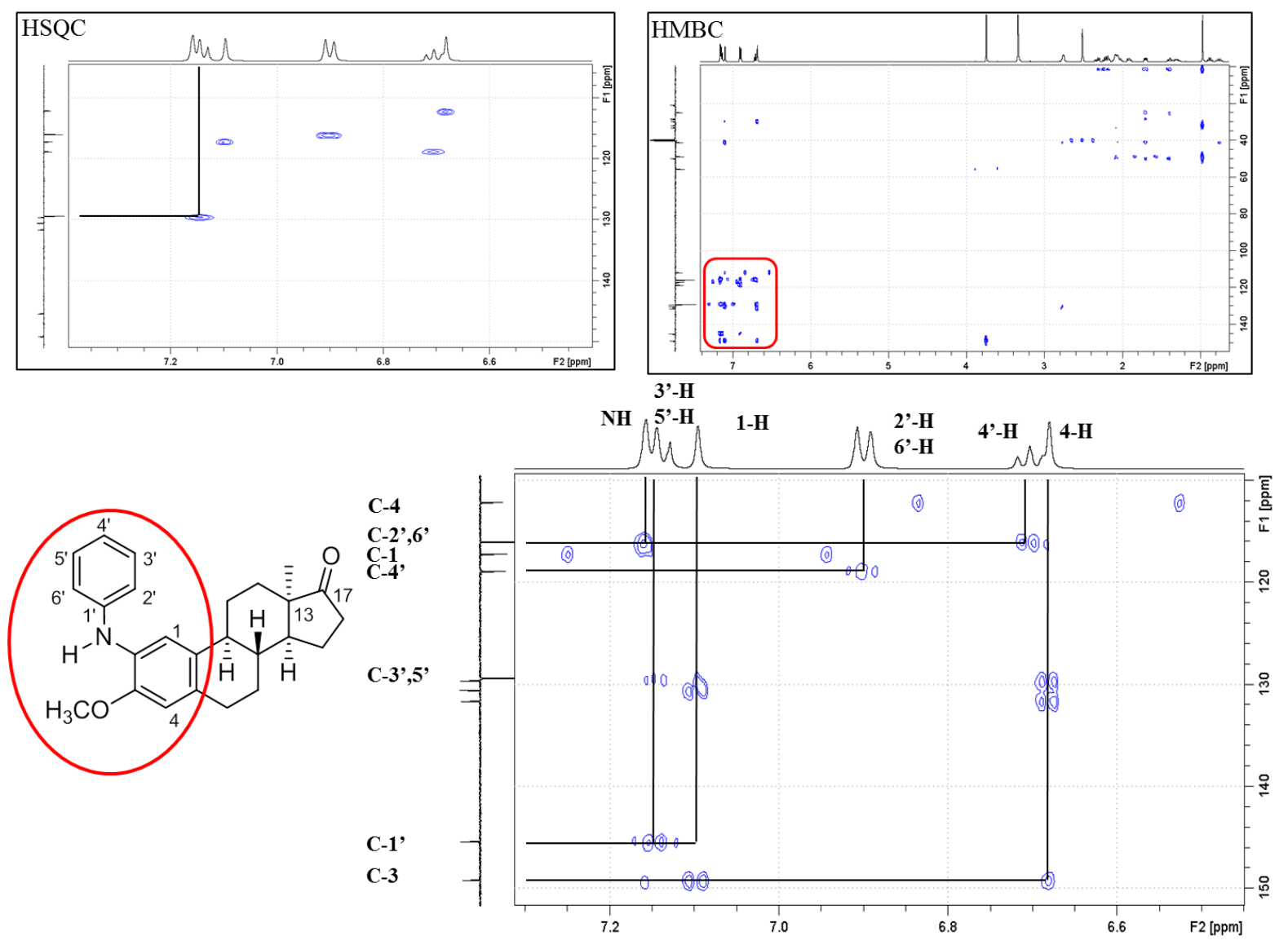

60. ábra A 157-es jelü vegyület HMBC és HSQC spektrumainak részlete

A 61. ábrán két kiindulási brómvegyület $(\mathbf{1 2 6}, \mathbf{1 2 7})$ és két céltermék fenilamino-származék spektrumrészlete látható. A 2-es pozícióban kapcsolt regioizomerek (126, 157) ${ }^{1} \mathrm{H}-\mathrm{NMR}$ spektrumain megfigyelhető, hogy a $6-\mathrm{CH}_{2}$ csoport protonjai egy átfedő multiplettként jelennek meg 3 ppm alatt. (61. ábra felső része). A 4-es regioizomer (161) ${ }^{1} \mathrm{H}-\mathrm{NMR}$ spektrumán (61. Ábra, jobb alsó részlete) a 6- $\mathrm{CH}_{2}$ protonok jelei szétválnak, ami utal arra hogy az alapváz 4-es szénatomjára szubsztituens épült be. A jelenség összhangban van a halogénvegyületeknél és Sonoghashira termékeknél tapasztalttal. 


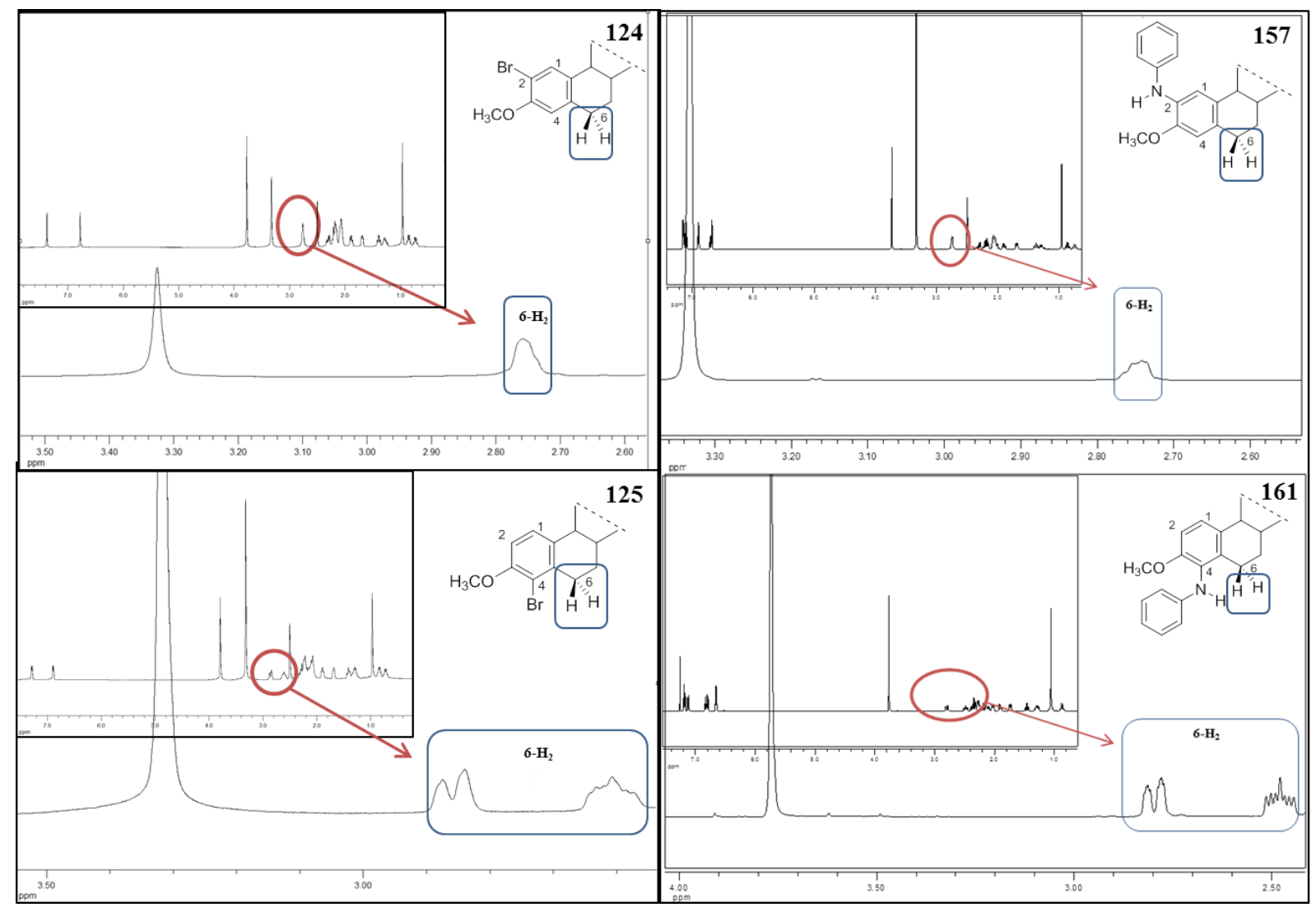

61. ábra A 124, 125, 157 és a 161-jelü vegyületek ${ }^{1} \mathrm{H}-\mathrm{NMR}$ spektrumainak kiemelt részletei 


\subsection{Fluoreszcens jelölés ösztrán vázon}

Munkánk folytatásában olyan fluoreszcensen jelölt ösztron származékok előállítását kívántuk megvalósítani, amelyek alkalmasak lehetnek egyes biológiai vizsgálatokban használt radioszubsztrátok kiváltására. ${ }^{\mathrm{V}}$ A fluoreszcens jelölő molekularészleteket olyan pozícióba terveztük az ösztrán vázra beépíteni, amely a biológiai kötődés szempontjából meghatározó 3-as és 17-es oxigéntartalmú funkciós csoportokat nem érinti. Választásunk a 2-es és a 15-ös szénatomokra esett, ugyanis figyelembe kellett vennünk a jelölések szerves kémiai megvalósítási lehetőségeit is. A konjugálásokat olyan összekapcsoló elem kialakításán keresztül céloztuk meg, amely kémiailag és biológiai rendszerekben is stabil. Mindezek érdekében a szteroid és a festék konjugálását CuAAC reakcióval, triazol-gyürü kapcsoló elem segítségével terveztük. A triazol-gyürü molekulában való jelenléte több szempontból is előnyös: egy olyan kémiailag és metabolitikusan is stabil kapcsoló elem, amely polaritásában és hidrogénkötés kialakítására való hajlamában a savamid kötéshez hasonló. A célból, hogy lehetőségünk nyíljon az ösztront CuAAC reakcióval a BODIPY festékhez kapcsolni, terminális alkin vagy azid funkciónak a szteroidon való kialakítására volt szükség. Nemcsak az ösztronon, hanem a BODIPY-festéken is létrehoztuk a komplementer csoportokat. Többféle BODIPY-alkin vagy -azid előállítását is terveztük, lehetőleg olyan származékokét, amelyekben a CuAAC reakcióban részt vevő csoport linkeren keresztül kapcsolódik a BODIPY alapvázhoz. Vizsgálni kívántuk a linker hosszának és rigiditásának hatását a ligandum kötődésére.

\subsubsection{A BODIPY-alkin elöállitása}

Az irodalomban már ismert festék-alkin (174) előállításához a pirrol (172) és aldehid reakcióstratégia alkalmazását választottuk Jurasek és munkatársai ${ }^{161,162}$ módszerének módosított változatával (62. ábra). Aldehid reakciópartnerként (170) fenolos hidroxilcsoportot tartalmazó, könnyen alkilezhető benzaldehidet választottunk. A terminális alkin funkciót már a reakciósor első lépésében bevittük a festékmolekulába. Az $O$-alkilezést $\mathrm{K}_{2} \mathrm{CO}_{3}$ bázis jelenlétében, propargil-bromiddal végeztük. A fenolétert (171) tehát egy a korábban kutatócsoportunkban szteroidon kidolgozott módszer alapján képeztük. ${ }^{16}$ Ezután következett az aldehid pirrollal végzett kondenzációs reakciója. Ez a lépés a reakciósor egyik legérzékenyebb pontja, ugyanis már a katalitikus mennyiségben alkalmazott TFA hatására végbemehet a pirrol polimerizációja. Ez utóbbi elkerülése érdekében a pirrolt (172) nagy

\footnotetext{
${ }^{\vee}$ Bacsa I., Konc C., Orosz A. B., Kecskeméti G., Rigó R., Özvegy-Laczka C., Mernyák E. Synthesis of novel C-2 or C-15 labeled BODIPY-estrone conjugates; Molecules, 2018, doi: 10.3390/molecules23040821
} 
feleslegben, oldószerként használtuk, ezzel elősegítve a dipirrometán (173) képződését, háttérbe szorítva a pirrol polimerizálódását és az egyéb melléktermékek keletkezését. A reakció az irodalomban ismertetett módszerhez képest gyorsabban és szelektívebben szolgáltatta a kívánt dipirrometánt (173). A festék konjugált kettős kötésű rendszerének kialakításához szükséges oxidációs lépést 5,6-diciano-2,3-diklór-1,4-benzokinon (DDQ) hozzáadásával végeztük, majd $\mathrm{Et}_{3} \mathrm{~N}$ és $\mathrm{BF}_{3} \cdot \mathrm{OEt}_{2}$ adagolásával alakítottuk ki a komplex végső formáját (174). A terminális alkin funkciót tartalmazó festék (174) szilikagélen történő kromatográfiás tisztításánál az eluensbe $\mathrm{Et}_{3} \mathrm{~N}-\mathrm{t}$ adagoltunk, hogy elkerüljük a nemkívánatos mellékreakciók lejátszódását, amelyek a szilikagél "savassága" hatására bekövetkezhetnek. További óvintézkedésként alumínium fóliába csavartuk a kromatográfiás oszlopot, hogy kiküszöböljük a fény hatására történő esetleges bomlási folyamatokat.
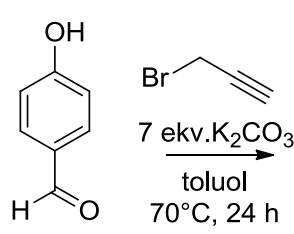

170

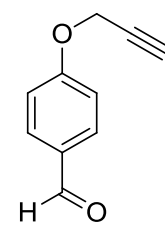

171

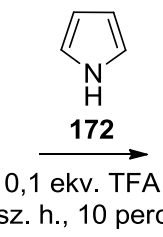

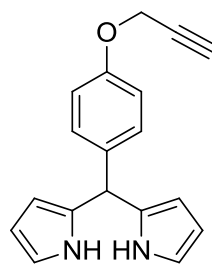

173

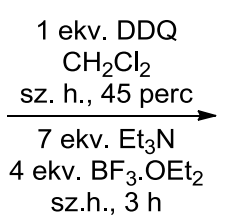

sz.h., $3 \mathrm{~h}$

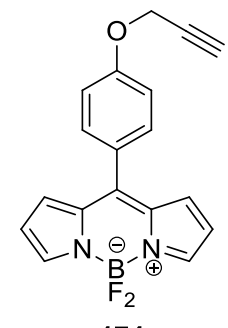

174

62. ábra A BODIPY-alkin (174) előállításának reakciósémája

\subsubsection{A BODIPY-azid elöállítása}

Az új festék-azid előállításához a savklorid-pirrol stratégiát alkalmaztuk (63. ábra), a szakirodalomban leírt módszerek módosításával. ${ }^{163,164}$ Kiindulási anyagként triszubsztituált pirrolt (177) választottunk a mellékreakciók (pl. polimerizáció) elkerülése érdekében. A pirrol reakciópartnereként az azid dipólus kialakításához bróm-azid cserére alkalmas alkilbromid oldallánccal rendelkező brómvegyületet választottunk (176). Ehhez az $\omega$-brómvaleriánsavból (175) in situ állítottuk elő a nála reaktívabb karbonsav-haloidot (176) oxalilkloriddal. A karbonsav-klorid készségesen reagált a 3-etil-2,4-dimetilpirrollal (177), kialakítva a kívánt dipirrometén intermediert. A célvegyület előanyagát (176) az intermedier izolálása nélkül, $\mathrm{BF}_{3} \cdot \mathrm{OEt}_{2}$ és bázis alkalmazásával nyertük. A kívánt festék-azid szintézisének utolsó lépéseként a BODIPY-bromidhoz $\mathrm{NaN}_{3}$-ot adtunk, így nyerve a BODIPY-azidot (179). 


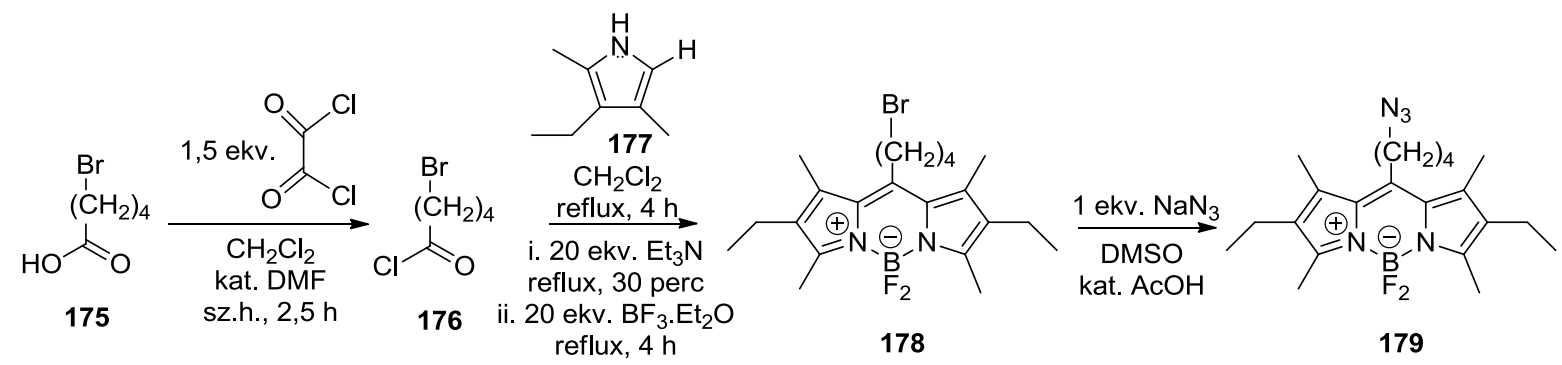

63. ábra A BODIPY-azid (179) előállításának reakciósémája

\subsubsection{Az ösztron azid és alkin elöállitása}

Az előállított BODIPY festékeket CuAAC reakcióban kívántuk az ösztronhoz kapcsolni. Ennek érdekében a következő lépésben a komplementer funkcióscsoportok kialakítását végeztük el a szteroidon. Az alkin vagy azid funkció beépítését a 17-es karbonil szénatomtól két szénatomnyira, a 15-ös helyzetbe terveztük. Kutatócsoportunkban korábban kidolgoztak egy hatékony eljárást a $13 \alpha$-ösztron 3-metil- és 3-benzilétere $\Delta^{15}$-származékának előállítására. ${ }^{165} \mathrm{Az} \alpha, \beta$-telítetlen keton (183) hasznos intermedierként szolgálhat további átalakításokhoz, például 15-szubsztituált származékok előállításához. A korábban 3-éterekre kidolgozott reakciósor alapján, először kialakítottuk a megfelelő védőcsoportokat az ösztronon. A mi célunk szabad fenolos hidroxilcsoporttal rendelkező ösztron-alkin vagy azid előállítása volt, ezért acetil-védőcsoporttal láttuk el 3-OH-t. A 17-es oxocsoportot etilénglikollal spiroketál funkciót kialakítva védtük. (64. ábra) Ezután következett a piridíniumhidrobromid-perbromiddal (PHPB) való reakció, amely sztereoszelektíven szolgáltatta a 16 $\alpha$ bróm vegyületet (181). ${ }^{166} \mathrm{Az}$ irodalomban ismeretes, hogy a 17-ketál ilyen brómozó szer hatására sztereoszelektíven kizárólag egy brómvegyületet ad. Az említett brómozó szer kiválóan alkalmas ketonok $\alpha$-helyzetü brómozására, könnyen kezelhető, levegőn kimérhető szilárd anyag. A brómozási reakció szelektivitására az adhat magyarázatot, hogy a merev öszrán vázon az anguláris metilcsoport sztérikus gátlása miatt a bróm kizárólag a $\alpha$ helyzetből képes támadni a 16-os szénatomra. A kettős kötés kialakítását a D-gyürüben $\mathrm{KO}^{t} \mathrm{Bu}$-tal végeztük, amely során a fenolos hidroxilcsoport dezacetileződése is lejátszódott. A ketál védőcsoport eltávolítását formalinban végeztük, mely során átacetálozási reakcióban nyertük a kívánt $\alpha, \beta$-telítetlen keton (183) kulcs intermediert. A 183 vegyületet Michaeladdícióval alakítottuk tovább a kívánt aziddá (184) vagy alkinné (185). Az azidálási lépéshez $\mathrm{NaN}_{3}$-ból $\mathrm{CH}_{3} \mathrm{COOH}$-val in situ generáltuk az azoimidet $\left(\mathrm{HN}_{3}\right)$, melynek azid ionja nukleofilként támadt a 15-ös szénatomra. Az 1,4-addíció során sztereoszelektíven képződött 
a 15 $\beta$-származék. A szakirodalomban ismeretes, hogy bizonyos nukleofilek, többek között az azid ion is, $\beta$-oldalról támadnak az $\alpha, \beta$-telítetlen ketonra. ${ }^{167} \mathrm{~A}$ terminális alkin funkciót propargil-alkohollal alakítottuk ki $\mathrm{K}_{2} \mathrm{CO}_{3}$ bázis jelenlétében, mely során szintén sztereoszelektíven nyertük a 15ß-O-propargil származékot. Az újonnan szintetizált szteroidalkinben (185) az etinilcsoport egy kétatomos linkeren keresztül kapcsolódik a szterán vázhoz.

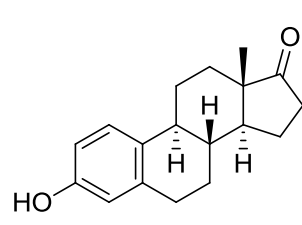

7(H)

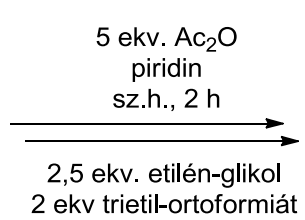

kat. $p$ - $\mathrm{TsOH}$ sz.h., $2 \mathrm{~h}$

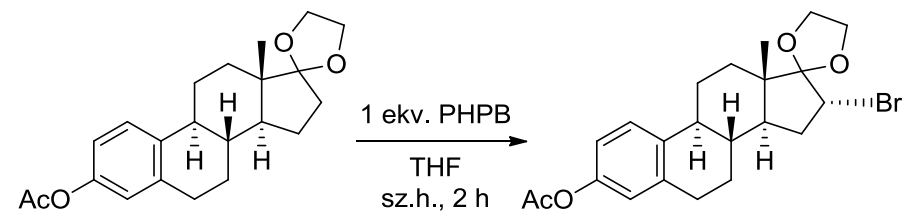

180
181

31 ekv. propargil-alkohol 5 csepp $5 \% \mathrm{NaOH}$ $\mathrm{CH}_{2} \mathrm{Cl}_{2}$ sz.h., $24 \mathrm{~h}$<smiles>[2H]c1ccc2c(c1)CC[C@@H]1[C@@H]2[C@H]2CC[C@@]1(C)C(=O)C[C@H]2N</smiles>

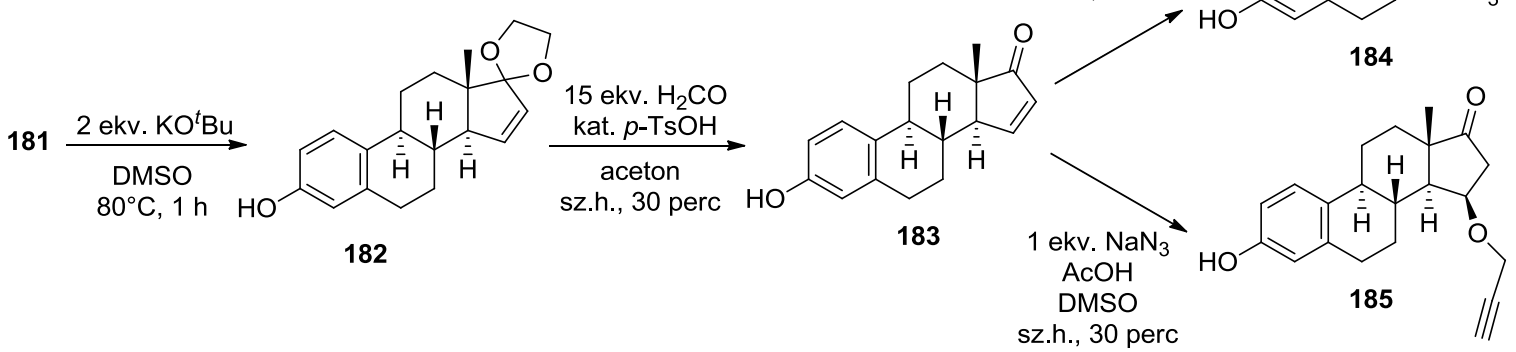

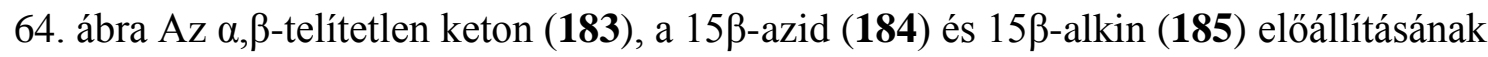
reakciósora

A terminális alkin funkció 15-ös szénatomon linkeren keresztül való kialakítását követően, a 2-es szénatomon annak közvetlen kialakítását is megvalósítottuk (65. ábra). Ehhez segítségül hívtuk az általunk fenil-acetilénekre kidolgozott Sonogashira kapcsolási eljárást (ld. 3.2. fejezet). Ahhoz, hogy 2-etinil származékot állítsunk elő az ösztronból, trimetilszililacetilénnel történő kapcsolásra volt szükség. Azt tapasztaltuk, hogy a saját módszerünk változtatás nélkül kiváló hozammal szolgáltatja a 23 -as vegyületet.

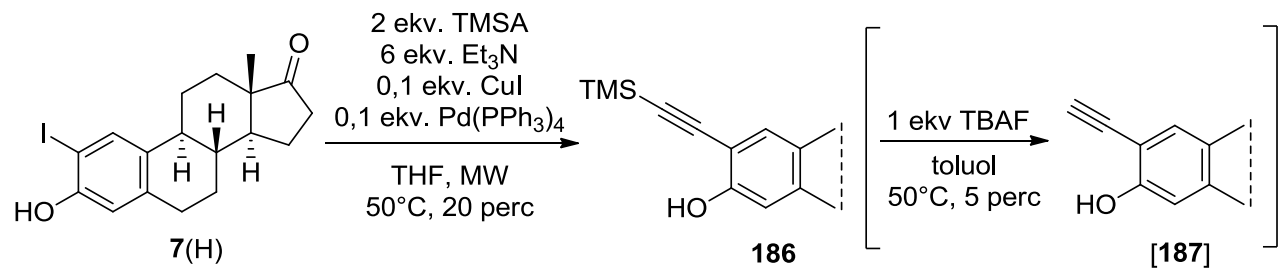

65. ábra A 2-etinilösztron (187) előállítása Sonogashira kapcsoláson keresztül 


\subsubsection{Fluoreszcens jelölés CuAAC reakcióval}

A komplementer azidok $(179,184)$ és alkinek $(\mathbf{1 7 4}, \mathbf{1 8 5})$ birtokában végrehajtottuk a tervezett CuAAC reakciókat a megfelelő párokkal. A kutatócsoportunkban korábban kidolgozott eljárást követve, $\mathrm{Cu}(\mathrm{I})$-katalizátorként $\mathrm{CuI}$-ot választottunk, bázisként diizopropil-etilamint (DIPEA), gyorsító ligandumként pedig $\mathrm{PPh}_{3}$-t. Hagyományos melegítéssel, 3 óra alatt kiváló hozammal nyertük a kívánt konjugátumokat $(\mathbf{1 8 8}, \mathbf{1 8 9})(66$. ábra).

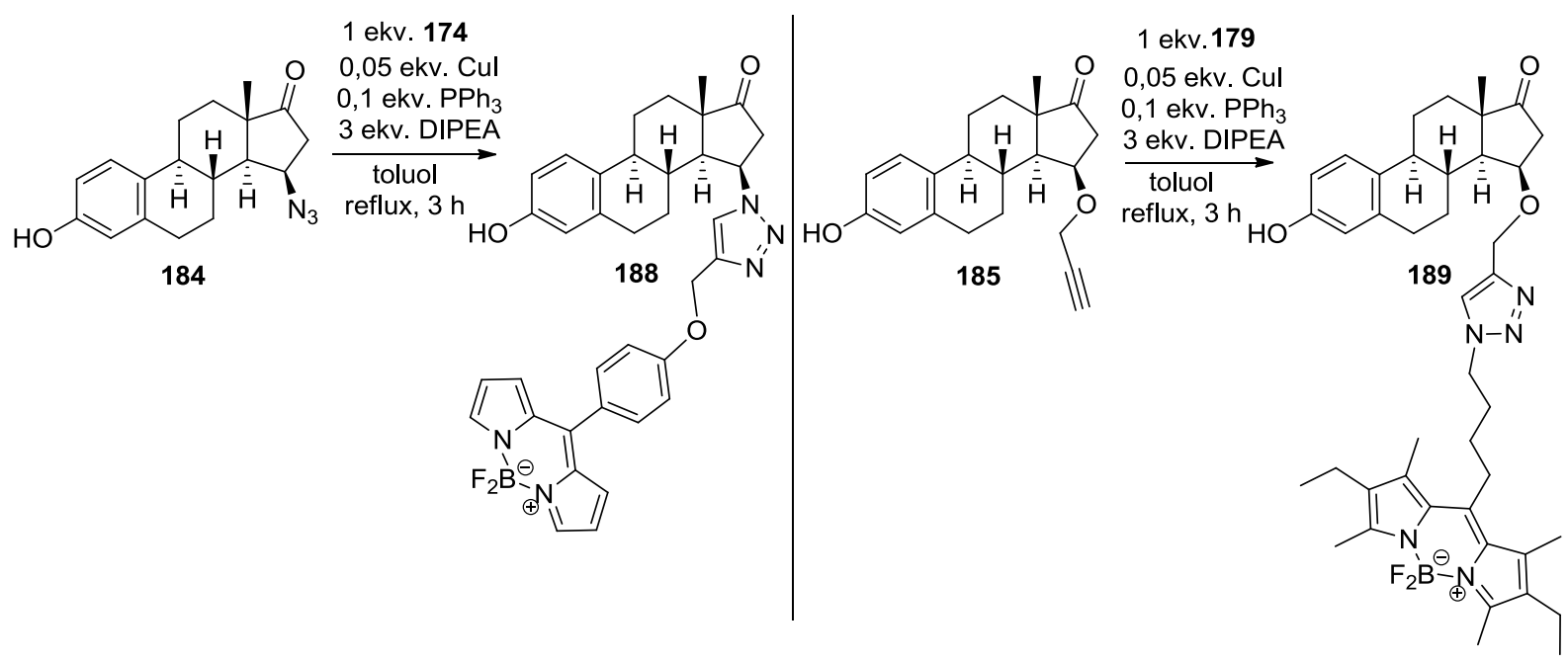

66. ábra Az ösztron fluoreszcens jelölése a D-gyürüjén keresztül

A 2-trimetilszililetinil-ösztron (186) esetében azt tapasztaltuk, hogy 1 ekvivalens tetrabutilammóniumfluorid (TBAF) hatására már szobahőmérsékleten is gyorsan, teljes konverzióval átalakul a kiindulási anyag. Azonban nem a várt terméket kaptuk, hanem a 3.3. fejezetben tárgyalt A-gyürühöz kondenzált benzo[b]furán származékot (190) (67. ábra). Annak elkerülése érdekében, hogy a benzofuránná történő gyürüzáródás megtörténjen, a trimetilszilil-csoport eltávolítását in situ végeztük el, a "click" reakció hőmérsékletén. Ezzel az eljárással rövid reakcióidővel, jó hozammal, sztereoszelektíven nyertük a kívánt származékot (191). 


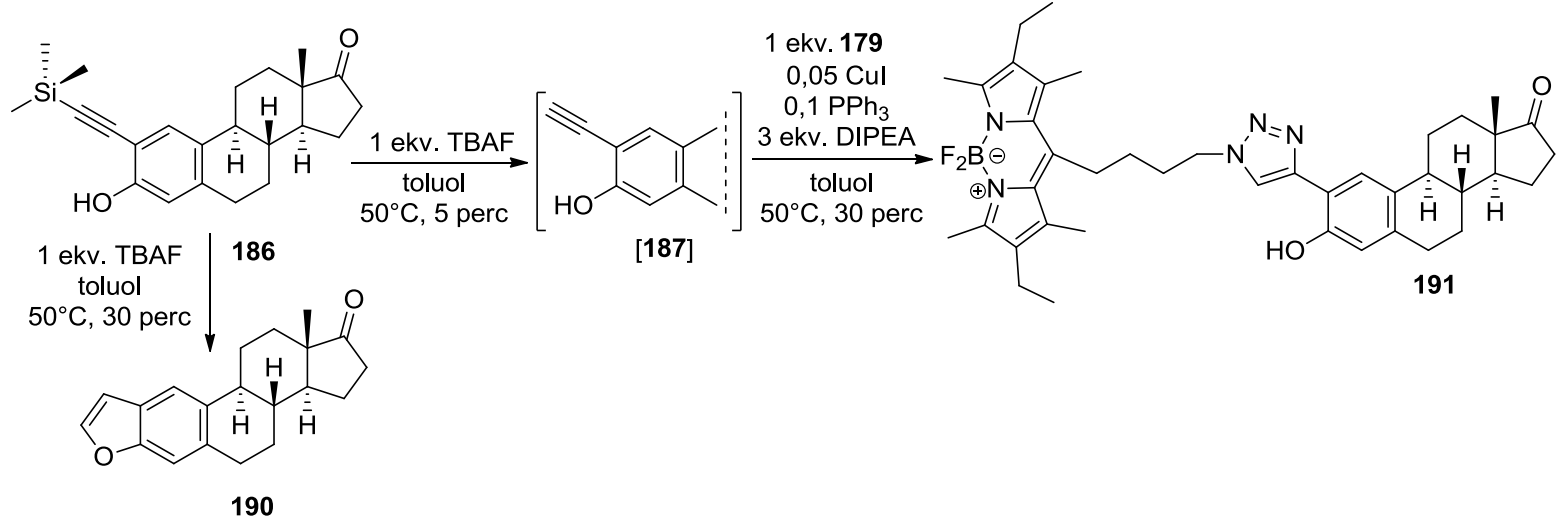

67. ábra Az ösztron 2-es helyzetben történő fluoreszcens jelölése

A célvegyületek szerkezetét NMR-spektroszkópiával igazoltuk. A 15-O-propargil származékról az ${ }^{1} \mathrm{H}$ - és a ${ }^{13} \mathrm{C}-\mathrm{NMR}$ spektrumokon túlmenően kétdimenziós felvételeket is készítettünk. A HSQC és a HMBC spektrumok segítségünkre voltak abban, hogy hozzárendeljük a 15-H és a két 16-H jelét. Ezután a NOESY-spektrum alapján megállapítottuk a 16-os hidrogének térállását, ugyanis az egyik jel (16ß-H) keresztcsúcsot adott az anguláris metilcsoport (13ß-Me) jelével (68. ábra). Azt feltételeztük, hogy a 15-H $\alpha$ térállású, ezért megvizsgáltuk, hogy a 15-H multiplettje a NOESY-felvételen keresztcsúcsot ad-e a $16 \alpha-\mathrm{H}$ jelével. A pozitív eredmény birtokában kijelenthetjük, hogy a nukleofil $O$ propargil csoport $\beta$-irányból intézett támadást a 15-ös szénatomra, 15 $\beta$-szubsztituált vegyületet (185) szolgáltatva. 

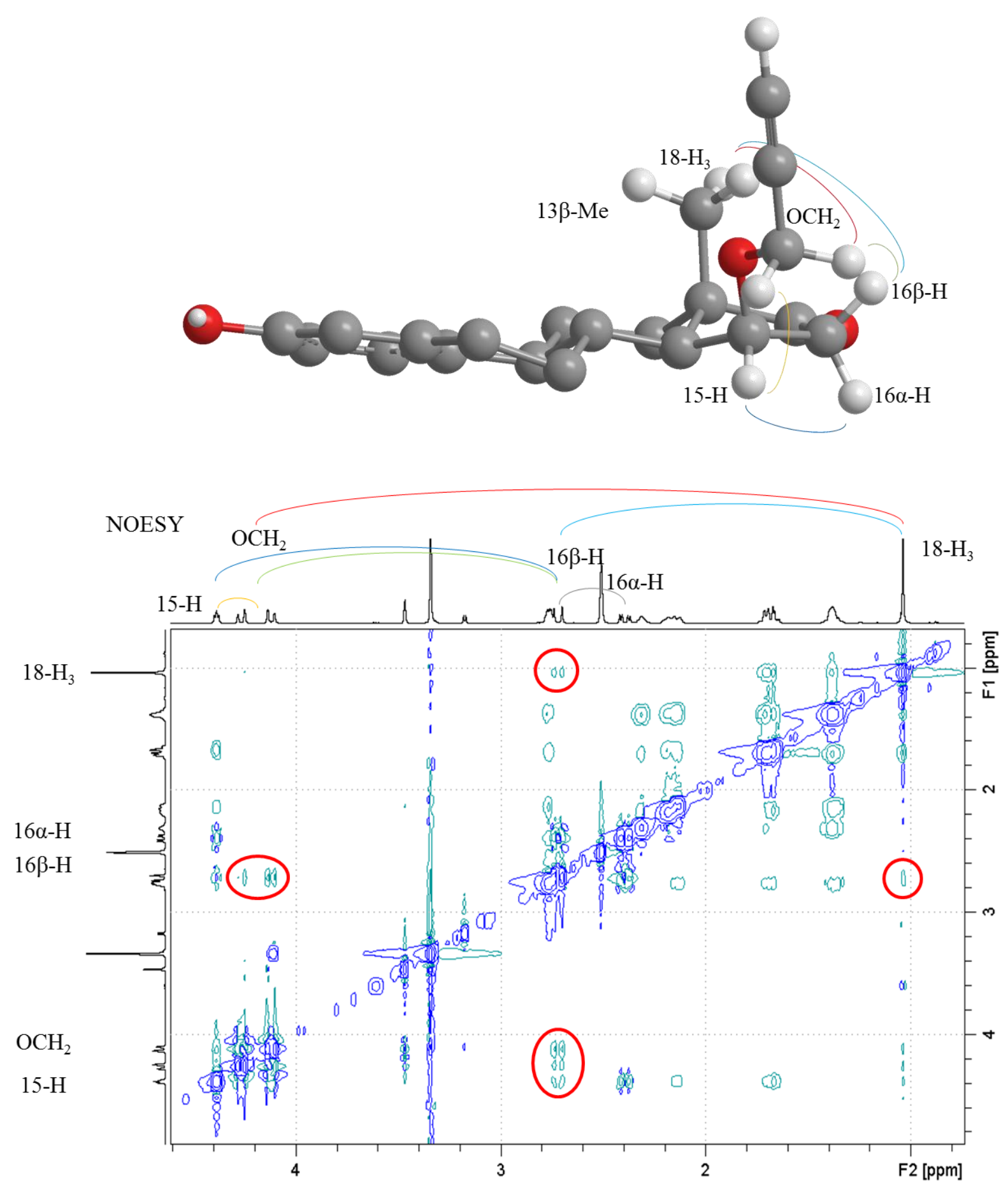

68. ábra Az 15ß-O-propargil származék NOESY spektruma

A 69. ábra a 188-es vegyület ${ }^{1} \mathrm{H}-\mathrm{NMR}$ spektrumát mutatja. A felvételen 1 ppm körül látható az anguláris metilcsoport hármas intenzitású szingulettje, 0,5-3 ppm tartományban a váz szekunder és tercier szénatomjain levő hidrogének jelei mutatkoznak. 5 ppm felett találhatók a molekula aromás, $\mathrm{NCH}, \mathrm{OCH}_{2}$ és $\mathrm{OH}$ protonjai. A kinagyított spektrumrészlet jól mutatja az $\alpha$-térállású 15-ös hidrogén jellegzetes multiplettjét, a karbociklusos és heterociklusos 
aromás protonok jellegzetesen felhasadt jeleit, illetve a 8 ppm feletti tartományban szingulettként mutatkozó triazolil $\mathrm{CH}-\mathrm{t}$ és fenolos $\mathrm{OH}-\mathrm{t}$.

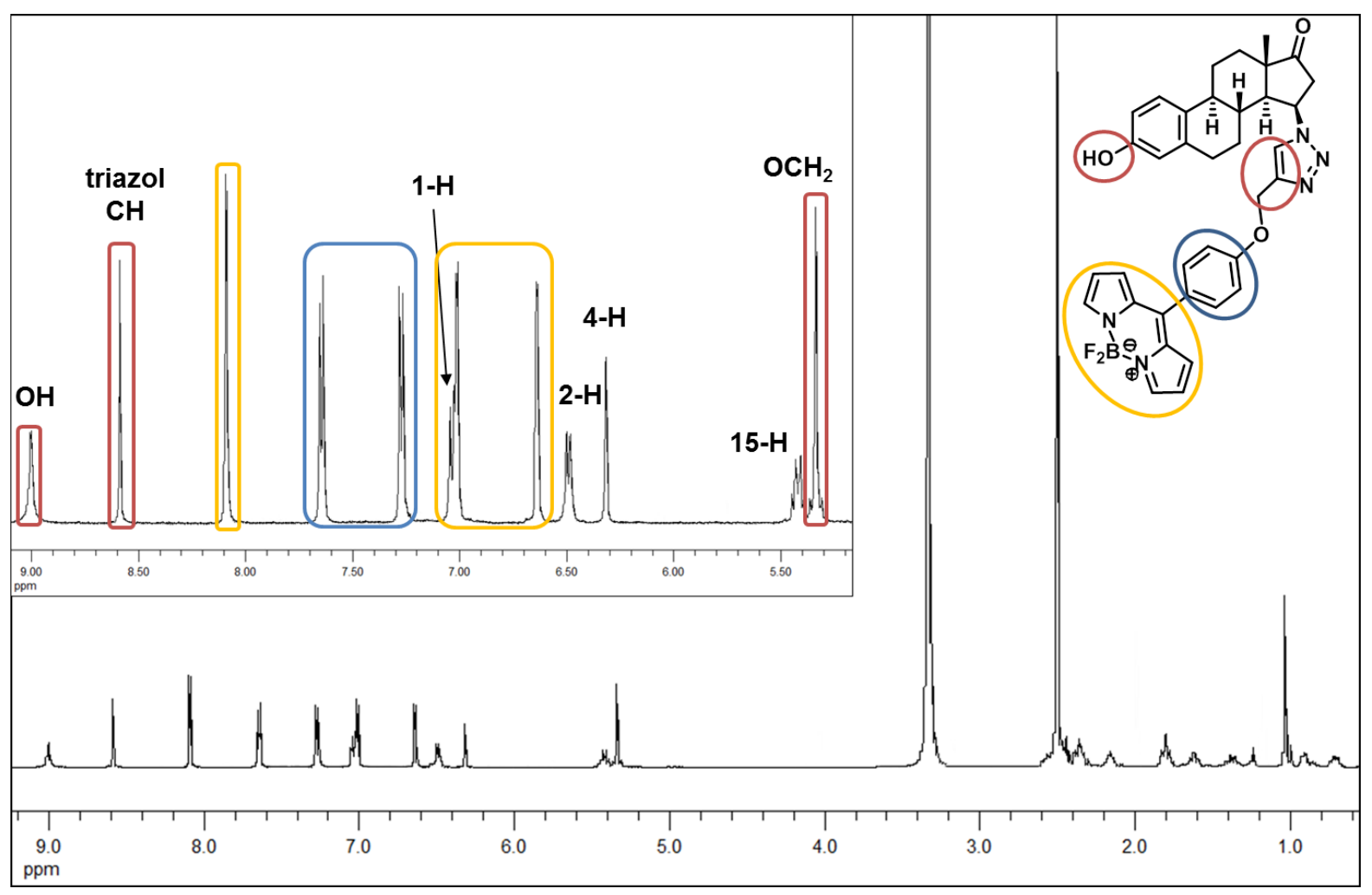

69. ábra A célvegyület (188) ${ }^{1} \mathrm{H}$ NMR spektruma

A 70. ábra az 188-os, 189-es és 191-as jelü vegyületek Chem3D programmal energiaminimalizált szerkezetét mutatja. A két 15-ös helyzetben jelölt konjugátumot összehasonítva látható, hogy az 188-os számmal jelölt vegyületnél, ahol a szteroid és a festék közvetlenül a triazol-gyürün keresztül kapcsolódik, merevebb szerkezetű vegyületet eredményez. A 189-as vegyület esetében azonban a szteroid felöl a két szénatomos, a BODIPY részéről pedig a négy szénatomos linkerek flexibilisebb kapcsolódást eredményeznek. A fluorofór ezáltal távolabb helyezkedik el az ösztrán váztól, ami megkönnyítheti az enzimekhez, receptorokhoz vagy egyéb biomolekulákhoz való kapcsolódását biológiai rendszerekben. A 2-es helyzetben jelölt származékban (191) szintén 2+4 szénatomos távoltartó csoport biztosítja a flexibilis mozgást, azonban az aromás A- és triazol-gyürü kötött elrendeződéséből adódóan a vegyület másik oldalára, azzal egy síkban, egy viszonylag fix térrészbe korlátozódik a mozgása. Ez olyan szempontból előnyös, hogy feltehetően nem korlátozza a szteroid rész biohozzáférhetőségét. 


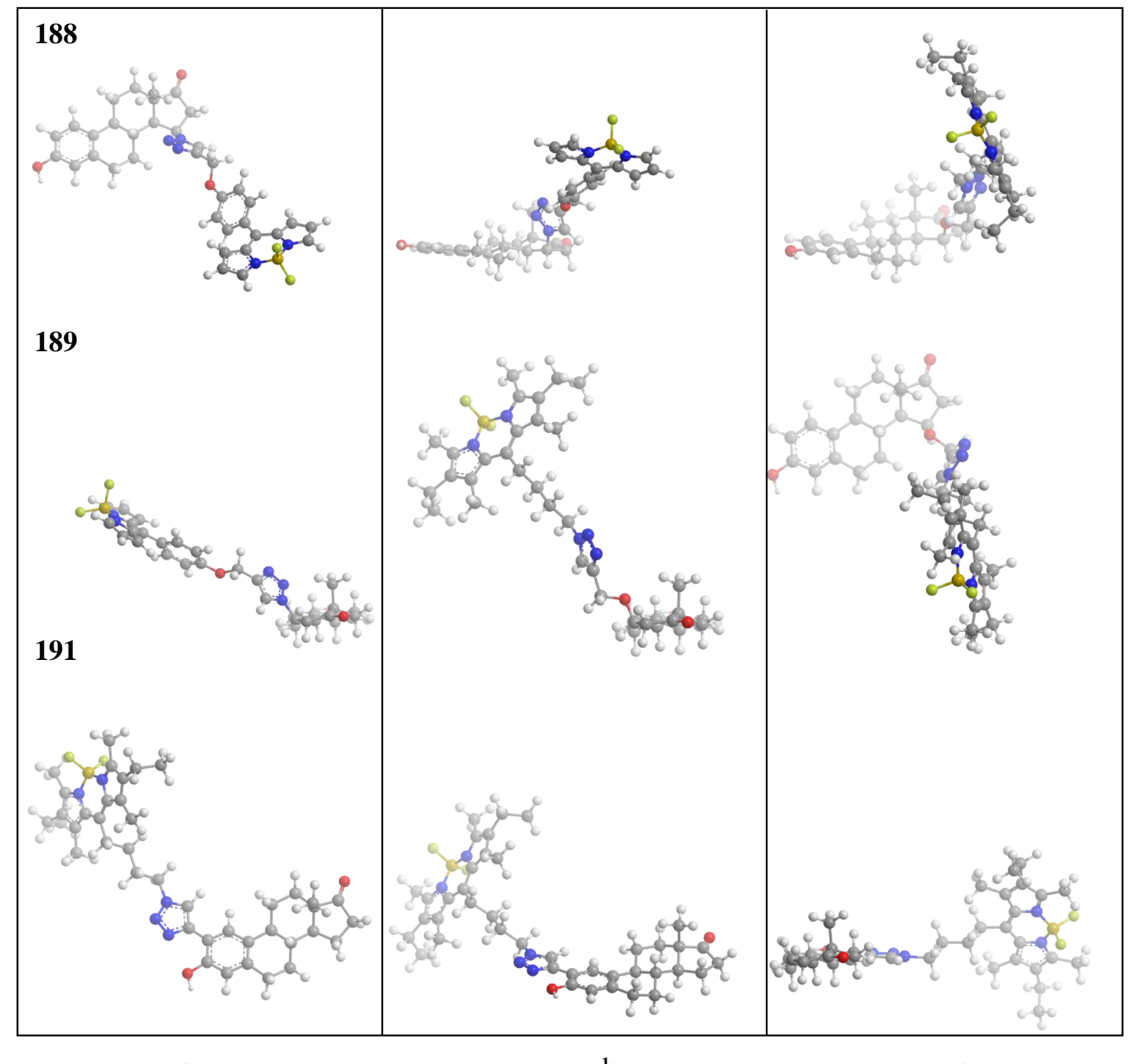

a

b

c

70. ábra A 188-as, 189-es és 191-es jelü vegyület Chem3D programmal energiaminimalizált szerkezetének felül (a), szemből (b), és oldalnézeti (c) képe

Az MTA-TTK Enzimológiai Intézetének Membránfehérje Kutatócsoportjával együttműködésben vizsgáltuk az újonnan előállított konjugátumokat (188, 189, 191), melyekről megállapítottuk, hogy alkalmas fluoreszcensen jelölt vegyületek lehetnek ösztronalapú biológiai vizsgálatokban. ${ }^{\mathrm{V}}$ 


\subsection{Enzimgátlási vizsgálatok az A gyürüben szubsztituált vegyületek körében}

A 3.1.-, 3.2.- és a 3.3.-as fejezetekben újonnan előállított vegyületek enzimgátlási vizsgálatait az SZTE I. sz. Belgyógyászati Klinika Endokrinológiai Laboratóriumában végezték. Az ösztrogének bioszintézisének kulcsenzimeire gyakorolt hatást in vitro módszerekkel vizsgálták. I, II, III

A 17ß-HSD1, a STS és az aromatáz enzimgátlási vizsgálatok eredményeit összevetve kitünt, hogy a legtöbb újonnan elöállított $13 \alpha$-ösztron származék és azok előanyagai is szelektíven gátolják egyik vagy másik enzim működését. Csupán egy-két esetben figyelhető

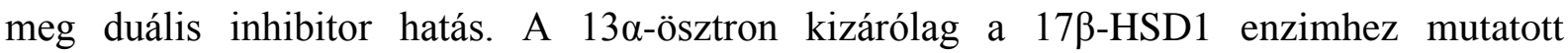
kiemelkedő affinitást. Ezen alapvegyületünk A-gyürüben halogénezett származékai az aromatázhoz nem, viszont egyes vegyületek a STS-hoz és a 17ß-HSD1-hez jelentős affinitást mutattak, akár az ösztron referenciával összemérhető gátló hatással. A monoszubsztituált vegyületeket illetően az STS-nél a 4-es, míg a 17ß-HSD1-nél a 2-es helyzetủ szubsztituálással sikerült hatékony inhibitorokat előállítanunk. A bisz-jódszármazék duális gátló hatást mutatott ezen két enzimen. A szabad fenolos OH-t tartalmazó 13a-ösztron származékok A-gyürüjének halogénezése tehát jó stratégiának bizonyult az alapvegyület inhibitor hatásának növelése

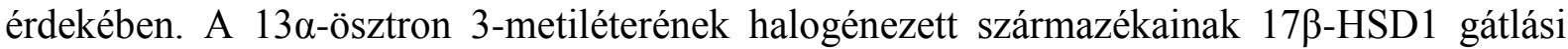
vizsgálatai arra a váratlan eredményre mutattak rá, hogy a 4-es helyzetü szubsztitúció kiemelkedő, a 3-OHs vegyületeknél tapasztalt legjobb gátlók adataival összemérhető hatáshoz vezet. A 17-dezoxi haloösztronok 17-keto párjuknál hatékonyabb STS inhibitoroknak bizonyultak.

A 3-OH 2-halogénvegyületek 2-fenetinil származékokká történő átalakításával sikerült fokoznunk a 17ß-HSD1 inhibitor hatást. A 4-fenetinil származékok egyike sem bizonyult jó inhibitornak. Az etinilcsoport teljes telítésével nyert etil-származékok enzimgátló hatása összemérhető a $13 \beta$-sorbeli analóg inhibitor vegyületével ${ }^{57}$ Kiemelendő, hogy a várt biológiai hatás szempontjából nincs jelentősége, hogy a 2-es szénatomhoz sp- vagy sp ${ }^{3}$-hibridállapotú szénatomokon keresztül kapcsolódik a lipofil molekularészlet. A 71. ábra 3 olyan vegyület szerkezetét mutatja, amelyek biológiai szempontból ígéretesnek bizonyultak. A 13a-ösztron sorban az A-gyürün végzett Sonogashira kapcsolás tehát a módosítás helyzetétől függően hatékony stratégiának bizonyult potens 17ß-HSD1 inhibitorok fejlesztéséhez. 

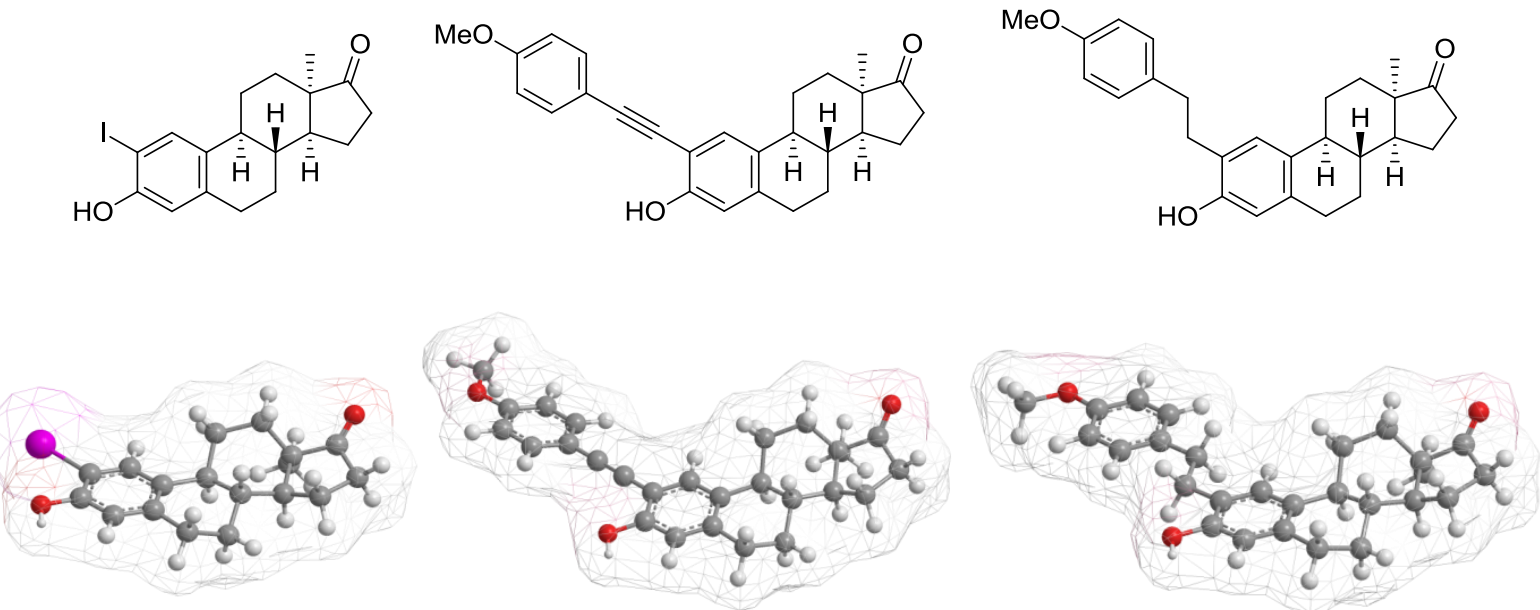

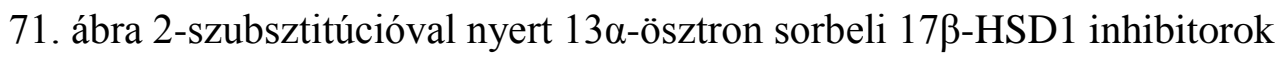

A 3.4. és pontban elöállított aminoösztronok és a 3.5.4. pontban szintetizált, fluoreszcensen jelölt ösztron származékok biológiai vizsgálatai folyamatban vannak együttműködő partnereinknél.

A biológiai eredmények alapján elmondható, hogy gondosan megtervezett, irányított szintézisek útján nyert új vegyületek elöállításával számos esetben sikerült javítanunk a kiindulási anyagok inhibitor hatásán. Adott típusú és méretü funkciós csoportok meghatározott pozícióba való beépítése gyakran előnyösnek bizonyult a gátló hatás szempontjából. 


\section{Kísérleti rész}

\section{1. Általános kísérleti rész}

A mikrohullámú reakciókat egy CEM, Discover SP készülékben hajtottuk végre, dinamikusan változó besugárzó teljesítménnyel, a hőmérséklet állandó értéken tartásával.

A reakciótermékek tisztítása és elválasztása 40-63 $\mu \mathrm{m}$ szemcseméretủ Kieselgel 60 (MERCK) álló fázissal töltött oszlopon történt.

A reakciók lefutását vékonyréteg-kromatográfiával követtük. Kieselgel 60 (MERCK), 0,2 mm vastagságú lapokat használtunk. A kromatogramokat a következő összetételű reagenssel való lefúvással és azt követő 10 perces $100-120{ }^{\circ} \mathrm{C}$-on történő melegítéssel hívtuk elő: $2,5 \mathrm{~g}$ $\mathrm{P}_{2} \mathrm{O}_{5} .24 \mathrm{MoO}_{3} \cdot \mathrm{H}_{2} \mathrm{O}, 25 \mathrm{ml} 85 \%$-os $\mathrm{H}_{3} \mathrm{PO}_{4}, 25 \mathrm{ml}$ víz. Az $\mathrm{R}_{\mathrm{f}}$-értékek megállapítása 254 vagy $365 \mathrm{~nm}$ hullámhosszúságú UV-fényben észlelt foltok alapján történt. Az $\mathrm{R}_{\mathrm{f}}$-értékeket a következő oldószer-rendszerekben határoztuk meg: (a) 30\% diizopropiléter/hexán (b) 80\% diizopropiléter/hexán, (c) $10 \%$ EtOAc/hexán, (d) $30 \%$ EtOAc/hexán, (e) $2 \%$ EtOAc/ $\mathrm{CH}_{2} \mathrm{Cl}_{2}$, (f) $20 \% \mathrm{EtOAc} / \mathrm{CH}_{2} \mathrm{Cl}_{2}$.

Az elóállított vegyületek olvadáspontját Kofler-blokkon mértük, korrekció nélkül.

A ${ }^{1} \mathrm{H}$ - és ${ }^{13} \mathrm{C}-\mathrm{NMR}$ spektrumok felvétele Bruker DRX-500 vagy Bruker Ascend 500 készülékkel történt, rendre $500 \mathrm{MHz}$-en és $125 \mathrm{MHz}$-en, $\mathrm{CDCl}_{3}$ vagy $\mathrm{DMSO}-\mathrm{d}_{6}$-ban oldószerben TMS-t alkalmazva belső standardként.

A tömegspektrumok Varian 500MS (I) vagy Agilent 500MS (II) ioncsapdás spektrométerrel, elektrospray ionizációs forrással, negatív (I) vagy pozitív (II) ion módban, 50-800 m/z tartományban készültek.

Az elemanalízist Perkin-Elmer CHN 2400 készülékkel végeztük. A vegyületek szén- és hidrogén analízis adatainak számított és mért értékei a hibahatárokon belül megegyeznek egymással. 


\subsection{Részletes kísérleti rész}

\subsubsection{Halogénezés - A 3.1. fejezetben tárgyalt reakciók leírása}

\subsubsection{Jódozás - A 3.1.1. fejezetben tárgyalt reakciók leírása}

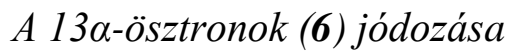

A $13 \alpha$-ösztront (13 $\alpha$-ösztra-1,3,5(10)-trién-17-ont $(\mathbf{6}(\mathrm{H}))(135 \mathrm{mg}, 0,50 \mathrm{mmol})$ vagy 3-Ometil-13 $\alpha$-ösztra-1,3,5(10)-trién-17-ont (6(Me)) (142 mg, 0,50 mmol) vagy 3-O-benzil-13 $\alpha$ ösztra-1,3,5(10)-trién-17-ont (6(Bn)) (180 mg, 0,50 mmol) vagy 2- vagy 4-bróm-13 $\alpha$-ösztra-

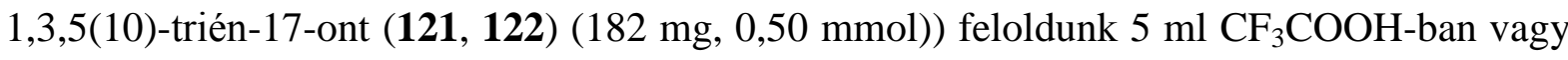
THF-ban vagy $\mathrm{CH}_{2} \mathrm{Cl}_{2}$-ban vagy katalitikus mennyiségü $\mathrm{CF}_{3} \mathrm{COOH}$-at vagy 1 ekvivalens $\mathrm{H}_{2} \mathrm{O}_{2}$-ot tartalmazó $\mathrm{CH}_{3} \mathrm{CN}$-ben. Hozzáadjuk az NIS-et $(112 \mathrm{mg}, 0,50 \mathrm{mmol}$ vagy $169 \mathrm{mg}$, 0,75 mmol) vagy a KI-ot $(0,50 \mathrm{mmol}, 83 \mathrm{mg})$, majd a reakcióelegyet 2 órán át szobahőmérsékleten kevertetjük. Ezután $100 \mathrm{ml}$ jeges vízre öntjük, híg $\mathrm{NH}_{4} \mathrm{OH}$ oldattal 10-es körüli pH-t állítunk be, $\mathrm{CH}_{2} \mathrm{Cl}_{2}$-nal extraháljuk, $\mathrm{Na}_{2} \mathrm{~S}_{2} \mathrm{O}_{3}$-ot adunk hozzá az el nem reagált jód eltávolítására, a szerves fázist izzított $\mathrm{Na}_{2} \mathrm{SO}_{4}$-on szárítjuk, és bepároljuk. A nyerstermékeket $(113,114,115 ; 116,117 ; 141 ; 142)$ oszlopkromatográfiásan tisztítjuk, 50\% diizopropil-éter/hexán eluens alkalmazásával.

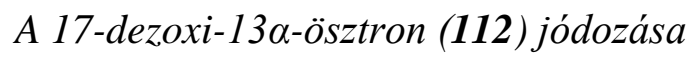

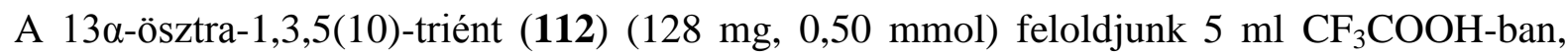
hozzáadjuk az NIS-et $(169 \mathrm{mg}, 0,75 \mathrm{mmol})$. A reakcióelegyet 2 órán át szobahőmérsékleten

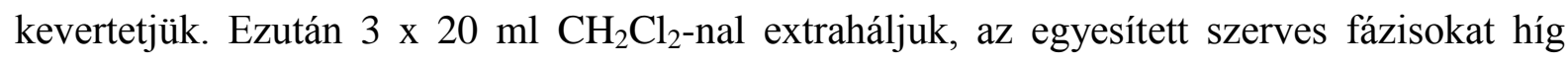
$\mathrm{NaHCO}_{3}$ oldattal, híg $\mathrm{Na}_{2} \mathrm{~S}_{2} \mathrm{O}_{3}$ oldattal, majd vízzel mossuk. A szerves fázist izzított $\mathrm{Na}_{2} \mathrm{SO}_{4}-$ on szárítjuk, és bepároljuk. A nyerstermékeket $(\mathbf{1 1 8}, 119,120)$ oszlopkromatográfiásan tisztítjuk 5\%-os, majd 20\%-os diizopropil-éter/hexán eluens alkalmazásával.

\subsubsection{A 3.1.2. fejezetben tárgyalt reakciók leirása-Brómozás}

A 13a-ösztronok (6) brómozása 


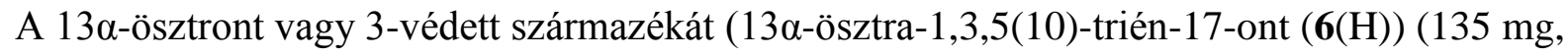
0,50 mmol) 3-O-metil-13 $\alpha$-ösztra-1,3,5(10)-trién-17-ont (6(Me)) (142 mg, 0,50 mmol), 3-Obenzil-13 $\alpha$-ösztra-1,3,5(10)-trién-17-ont $(\mathbf{6}(\mathrm{Bn}))(180 \mathrm{mg}, 0,50 \mathrm{mmol})) \mathrm{CH}_{2} \mathrm{Cl}_{2}$-ban $(5 \mathrm{ml})$ vagy THF-ban $(13 \mathrm{ml})$ vagy DMSO-ban $(5 \mathrm{ml})$ vagy $\mathrm{CH}_{3} \mathrm{CN}$-ben $(5 \mathrm{ml})$ vagy DMF-ban (5 ml) oldunk, majd hozzáadjuk az NBS-et (89 mg, 0,50 mmol vagy $133 \mathrm{mg}, 0,75 \mathrm{mmol}$ ) vagy a DDH-t (71 mg, 0,25 mmol). A reakcióelegyet 2-3 órán át szobahőmérsékleten kevertetjük. A nyerstermékeket $(121,122,123 ; 124,125 ; 126,127)$, a reakcióelegy bepárlását követően, oszlopkromatográfiásan tisztítjuk, 50\% diizopropil-éter/hexán vagy 5\% EtOAc/hexán eluens alkalmazásával.

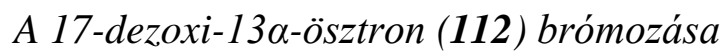

A 17-dezoxi vegyületet (13 $\alpha$-ösztra-1,3,5(10)-triént (112) $(0,05 \mathrm{mmol}, 128 \mathrm{mg}))$ feloldjuk 5 $\mathrm{ml} \mathrm{CH} \mathrm{Cl}_{2}$-ban, majd hozzáadjuk az NBS-et $(0,55 \mathrm{mmol}, 98 \mathrm{mg})$. A reakcióelegyet 1 órán át szobahőmérsékleten kevertetjük. A termékkeveréket $(\mathbf{1 2 8}, \mathbf{1 2 9}, \mathbf{1 3 0})$ a reakcióelegy bepárlását követően, oszlopkromatográfiásan tisztítjuk 5\%-os, EtOAc/hexán eluens alkalmazásával.

\subsubsection{A 3.1.3. fejezetben tárgyalt reakciók leírása-Klórozás}

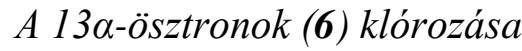

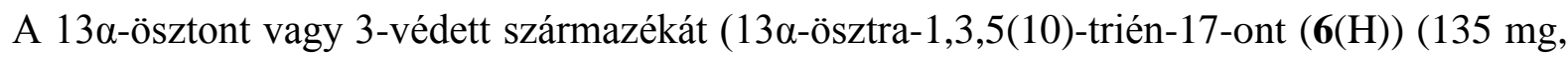
0,50 mmol) vagy 3-O-metil-13 $\alpha$-ösztra-1,3,5(10)-trién-17-ont (6(Me)) (142 mg, 0,50 mmol) vagy 3-O-benzil-13 $\alpha$-ösztra-1,3,5(10)-trién-17-ont (6(Bn)) (180 mg, 0,50 mmol) $5 \mathrm{ml}$ $\mathrm{CF}_{3} \mathrm{COOH}-$ ban vagy katalitikus mennyiségü $\mathrm{CF}_{3} \mathrm{COOH}$-at tartalmazó $\mathrm{CH}_{3} \mathrm{CN}$-ben oldjuk, $0^{\circ} \mathrm{C}$-ra hütjük, majd hozzáadjuk az NCS (67 mg, 0,50 mmol, $\left.134 \mathrm{mg}, 1,00 \mathrm{mmol}\right)$. Hagyjuk szobahőmérsékletre melegedni, és 24 órán át kevertetjük. Ezután $100 \mathrm{ml}$ jeges vízre öntjük, és dietiléterrel extraháljuk, $\mathrm{Na}_{2} \mathrm{~S}_{2} \mathrm{O}_{3}$-ot adunk hozzá, a szerves fázist izzított $\mathrm{Na}_{2} \mathrm{SO}_{4}$-on szárítjuk, és bepároljuk. A nyerstermékeket (131, 132, 133; 134 135; 136, 137, 36) oszlopkromatográfiásan tisztítjuk, 30\% diizopropil-éter/hexán eluens alkalmazásával. 


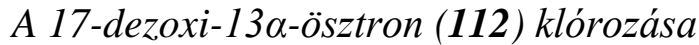

A 17-dezoxi vegyületet (3-hidroxi-13 $\alpha$-ösztra-1,3,5(10)-triént (112) (256 mg, 1,0 mmol)) feloldjuk $20 \mathrm{ml} \mathrm{CH}{ }_{3} \mathrm{CN}$-ben, hozzáadjuk az NCS-et (200 mg, 1,5 mmol vagy $400 \mathrm{mg}, 3,0$ mmol). A reakcióelegyet mikrohullámú reaktorban 40 percen át $80{ }^{\circ} \mathrm{C}$-on reagáltatjuk. A nyerstermékeket (138, 139, 140) oszlopkromatográfiásan tisztítjuk 30\%-os diizopropiléter/hexán eluens alkalmazásával.

\subsubsection{Sonogashira keresztkapcsolás A-gyürüben - A 3.2. fejezetben tárgyalt reakciók leírása}

\section{Sonogashira kapcsolás a 2-es helyzetben}

Mikrohullámú besugárzásra alkalmas reakcióedényben a megfelelő jódszármazékhoz (3hidroxi-2-jód-13 $\alpha$-ösztra-1,3,5(10)-trién-17-ont (113) (50 mg, 0,18 mmol) vagy 2-jód-3-O-

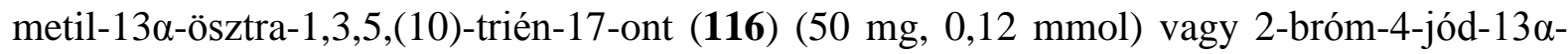
ösztra-1,3,5(10)-trién-17-ont (141) (237 mg, 0,50 mmol)) vagy 4-bróm-2-jód-13 $\alpha$-ösztra1,3,5(10)-trién-17-ont (142) (237 mg, 0,50 mmol)) rendre hozzáadjuk a $10 \mathrm{~mol} \% \mathrm{Pd}\left(\mathrm{PPh}_{3}\right)_{4}$ katalizátort (20 mg, 0,018 mmol vagy $14 \mathrm{mg}, 0,012 \mathrm{mmol})$ és a $10 \mathrm{~mol} \%$ CuI-ot (3,4 mg, 0,018 mmol vagy $2,3 \mathrm{mg}, 0,012 \mathrm{mmol}) 3 \mathrm{ml}$ THF vagy DMF oldószert, majd a 6 ekvivalens $\mathrm{Et}_{3} \mathrm{~N}$-t $(0,1 \mathrm{ml}, 0,72 \mathrm{mmol})$ és $\mathrm{N}_{2}$ atmoszféra alatt, $50{ }^{\circ} \mathrm{C}$-on 10 percig előkevertetjük. Ezután adjuk hozzá a 2 ekvivalens $p$-helyzetben különböző szubsztituenst tartalmazó fenil-acetilént $(143 a-\mathbf{e})$. A reakció $50{ }^{\circ} \mathrm{C}$-on, CEM mikrohullámú reaktor alkalmazásával, 20 perc alatt játszódik le. A reakcióelegyet bepároljuk. A nyers termékeket (144a-e, 146a-i) oszlopkromatográfiával tisztítjuk, 50\% diizopropil-éter/hexán eluens alkalmazásával.

\section{Sonogashira kapcsolás a 4-es helyzetben}

Mikrohullámú besugárzásra alkalmas reakcióedényben a megfelelő jódszármazékhoz (3hidroxi-4-jód-13 $\alpha$-ösztra-1,3,5(10)-trién-17-ont (114) $(50 \mathrm{mg}, 0,18 \mathrm{mmol})$ vagy 4-jód-3-Ometil-13 $\alpha$-ösztra-1,3,5,(10)-trién-17-ont (116) (50 mg, 0,12 mmol) rendre hozzáadjuk a 10 $\mathrm{mol} \% \mathrm{Pd}\left(\mathrm{PPh}_{3}\right)_{4}$ katalizátort (20 mg, 0,018 mmol vagy $14 \mathrm{mg}, 0,012 \mathrm{mmol}$ ) és a $10 \mathrm{~mol} \%$ CuI-ot (3,4 mg, 0,018 mmol vagy 2,3 mg, 0,012 mmol) $3 \mathrm{ml} \mathrm{CH} \mathrm{CH}_{3} \mathrm{CN}$ vagy DMF oldószert, majd a 6 ekvivalens $\mathrm{Et}_{3} \mathrm{~N}$-t $(0,1 \mathrm{ml}, 0,72 \mathrm{mmol})$ és $\mathrm{N}_{2}$ atmoszféra alatt, $80{ }^{\circ} \mathrm{C}$-on 2 percig elökevertetjük. Ezután 2 ekvivalens $p$-helyzetben különböző szubsztituenst tartalmazó fenil- 
acetilént $(143 \mathbf{a}-\mathbf{e})$ adunk hozzá. A reakció $80{ }^{\circ} \mathrm{C}$-on, CEM mikrohullámú reaktor alkalmazásával, 20 perc alatt lejátszódik. A reakcióelegyeket közvetlenül szilikagélre pároljuk és a nyers termékeket $(\mathbf{1 4 5 a}-\mathbf{e}, \mathbf{1 4 7 a}-\mathbf{i})$ oszlopkromatográfiával tisztítjuk, 30\% diizopropil-éter/hexán eluens alkalmazásával.

\subsubsection{Az alkin funkció részleges és teljes telitése - A 3.3. fejezetben tárgyalt reakciók leírása}

A részleges telités és benzo[b]furán képzés általános leirása

A kiválasztott fenilalkinil származékokat (3-hidroxi-2- vagy 3-hidroxi-4-[(4metoxifenil)etinil]-13 $\alpha$-ösztra-1,3,5(10)-trién-17-ont (144c, 145c) (48 mg, 0,12 mmol) vagy 3-O-metil-2- vagy 3-O-metil-4-[(4-metoxifenil)etinil]-13 $\alpha$-ösztra-1,3,5(10)-trién-17-ont (146c, 147c) (50 mg, 0,12 mmol)) $3 \mathrm{ml}$ vízmentes DMF-ben oldunk, hozzáadjuk a Pd(OAc) $2_{2}^{-}$ ot $(2,7 \mathrm{mg}, 0,012 \mathrm{mmol})$ vagy a $\mathrm{Pd}\left(\mathrm{PPh}_{3}\right)_{2} \mathrm{Cl}_{2}(2,8 \mathrm{mg}, 0,004 \mathrm{mmol})$ katalizátort, majd a $\mathrm{KOH}$-ot (112,0 mg, 2,0 mmol) $\mathrm{N}_{2}$ atmoszféra alatt. A reakció mikrohullámú reaktorban, 50 W-on 35 perc alatt játszódik le. A reakcióelegyet közvetlenül szilikagélre pároljuk és a nyersterméket (148, 149, 150, 151) oszlopkromatográfiával tisztítjuk 30\% diizopropiléter/hexán eluenst alkalmazva.

\section{A fenetenil-származékok cisz-transz izomereinek egymásba alakitása}

A kiválasztott feniletenil származékokat (3-O-metil-2- vagy 3-O-metil-4-[(4metoxifenil)etenil]-13 $\alpha$-ösztra-1,3,5(10)-trién-17-ont $(\mathbf{1 4 8}, \mathbf{1 4 9})(50 \mathrm{mg}, 0,12 \mathrm{mmol})) 1 \mathrm{ml}$ vízmentes toluolban oldunk, hozzáadunk katalitikus mennyiségü elemi jódot ( $1 \mathrm{mg}, 0,004$ mmol), majd szobahőmérsékleten 24 órát kevertetjük. A reakcióelegyet dietiléterrel elhígítjuk, szilikagélre pároljuk és oszlopkromatográfiával tisztítjuk 0,5\% EtOAc/hexán eluenst alkalmazva

A fenetinil származékok (144c, 145c, 146c, 147c) teljes telitése

A kiválasztott fenetinil származékokat (3-hidroxi-2- vagy 3-hidroxi-4-[(4-metoxifenil)etinil]$13 \alpha$-ösztra-1,3,5(10)-trién-17-ont (144c, 145c) (48 mg, 0,12 mmol) vagy 3-O-metil-2- vagy 3-O-metil-4-[(4-metoxifenil)etinil]-13 $\alpha$-ösztra-1,3,5(10)-trién-17-ont (146c, 147c) $(50 \mathrm{mg}$, 
0,12 mmol)) felszuszpendáljuk $30 \mathrm{ml}$ EtOAc-ban, és hozzáadjuk a Pd/C katalizátort (72 mg, 10\%). A reakció 20 bar $\mathrm{H}_{2}$ nyomás mellett, szobahőmérsékleten 1 óra alatt játszódik le. A katalizátor eltávolításához a reakcióelegyet Celite ${ }^{\circledR}$-en szürjük. A nyersterméket $(\mathbf{1 5 2} ; \mathbf{1 5 3}$; 154; 155) szilikagélre párolva oszlopkromatográfiával tisztítjuk, 30\% diizopropil-éter/hexán eluenst alkalmazva.

4.2.4. Buchwald-Hartwig aminálás A-gyürüben - A 3.4. fejezetben tárgyalt reakciók leírása

Buchwald-Hartwig aminálás mikrohullámú besugárzással

Mikrohullámú besugárzásra alkalmas reakcióedénybe $\mathrm{Pd}(\mathrm{OAc})_{2}$-ot $(6 \mathrm{mg}, 0,025 \mathrm{mmol}, 10$ mol\%) vagy $\mathrm{Pd}_{2}(\mathrm{dba})_{3}$-ot $(11 \mathrm{mg}, 0,0125 \mathrm{mmol}, 5 \mathrm{~mol} \%)$, KO ${ }^{t} \mathrm{Bu}$-ot $(6 \mathrm{mg}, 0,5 \mathrm{mmol}, 2$ ekv.) vagy DBU-t (76 mg, 0,5 mmol, $2 \mathrm{ekv}$.) vagy $\mathrm{Cs}_{2} \mathrm{CO}_{3}$-ot (163 mg, 0,5 mmol $2 \mathrm{ekv}$.), XPhos-t (12 mg, 0,025 mmol $10 \mathrm{~mol} \%$ ) vagy BINAP-ot (16 mg, 0,025 mmol $10 \mathrm{~mol} \%$ ), anilint $(0,30 \mathrm{mmol})$ vagy benzofenon-imint $(54 \mathrm{mg}, 0,30 \mathrm{mmol})$ és toluolt $(5 \mathrm{ml})$ teszünk, nitrogén atmoszférában $60{ }^{\circ} \mathrm{C}$-on 5 percig kevertetjük, majd szobahőmérsékletre hütjük. Hozzáadjuk a megfelelő bróm-szteroidot (2-bróm- vagy 4-bróm-3-O-metil-13 $\alpha$-ösztra1,3,5,(10)-trién-17-ont, 124, 125) (91 mg, 0,25 mmol), vagy a (3- $O$-benzil-2-bróm- vagy 3$O$-benzil-4-bróm-13 $\alpha$-ösztra-1,3,5,(10)-trién-17-ont, 126, 127 (110 mg, 0,25 mmol)) és a reakcióelegyet nitrogén atmoszférában $100{ }^{\circ} \mathrm{C}$-on tartva 10 percig mikrohullámú reaktorban keverjük. A mikrohullámú besugárzás maximális teljesítménye $200 \mathrm{~W}$ volt. Az oldószert bepárlással eltávolítjuk. A nyersterméket $(157 ; 158 \mathrm{a}-\mathbf{d} ; 159 \mathrm{a}-\mathrm{d} ; 160 \mathrm{a}-\mathrm{d} ; 161 ; 162 ; 163$; 164) oszlopkromatográfiával tisztítjuk, $15 \%$ EtOAc/hexán eluens alkalmazásával.

\section{Buchwald-Hartwig aminálás hagyományos melegítéssel}

Gömblombikba $\mathrm{Pd}(\mathrm{OAc})_{2}$-ot $(6 \mathrm{mg}, 0,025 \mathrm{mmol}, 10 \mathrm{~mol} \%)$ vagy $\mathrm{Pd}_{2}(\mathrm{dba})_{3}$-ot $(11 \mathrm{mg}$, 0,0125 mmol, $5 \mathrm{~mol} \%$ ), $\mathrm{KO}^{t} \mathrm{Bu}-\mathrm{ot}(6 \mathrm{mg}, 0,5 \mathrm{mmol}, 2 \mathrm{ekv}$.) vagy DBU (76 mg, 0,5 mmol, 2 ekv.) vagy $\mathrm{Cs}_{2} \mathrm{CO}_{3}$ (163 mg, 0,5 mmol 2 ekv.), XPhos-t (12 mg, 0,025 mmol $10 \mathrm{~mol} \%$ ) vagy BINAP-ot (16 mg, 0,025 mmol $10 \mathrm{~mol} \%)$, anilint (0,30 mmol) vagy benzofenon-imint (54 $\mathrm{mg}, 0,30 \mathrm{mmol})$ és toluolt $(5 \mathrm{ml})$ teszünk, nitrogén atmoszférában $60{ }^{\circ} \mathrm{C}$-on 5 percig keverjük, majd szobahőmérsékletre hütjük. Hozzáadjuk a megfelelő bróm-szteroidot (2- 
bróm- vagy 4-bróm-3-O-metil-13 $\alpha$-ösztra-1,3,5,(10)-trién-17-ont, 124) és a reakcióelegyet nitrogén atmoszférában forraljuk 24 óráig. Az oldószert bepárlással eltávolítjuk. A nyersterméket (157) oszlopkromatográfiával tisztítjuk, $15 \%$ etil-acetát/hexán eluens alkalmazásásval.

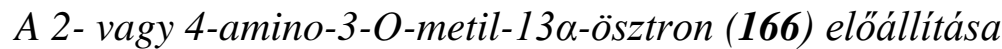

A benzofenon-iminnel kapcsolt származékot $(\mathbf{1 6 4}, \mathbf{1 6 5})(100 \mathrm{mg}, 0,215 \mathrm{mmol})$ oldjuk $5 \mathrm{ml}$ THF-ban, és hozzáadunk $50 \mu 1$ 2M-os HCl-at. A reakció szobahőmérsékleten 3 óra alatt játszódik le. A nyersterméket $(\mathbf{1 6 7}, \mathbf{1 6 8})$ bepárlást követően oszlopkromatográfiával tisztítjuk, 40\% EtOAc/hexán eluenst alkalmazva.

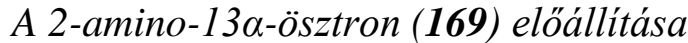

A benzofenon-iminnel kapcsolt származékot (166) (100 mg, 0,185 mmol) oldjuk $20 \mathrm{ml}$ etilacetátban, és hozzáadjuk a $\mathrm{Pd} / \mathrm{C}$ katalizátort (35 mg, 10\%). A reakció 20 bar $\mathrm{H}_{2}$ nyomás mellett, szobahőmérsékleten 1 óra alatt játszódik le. A katalizátor eltávolításához a nyersterméket (169) Celite ${ }^{\circledR}$-en szürjük, majd bepárlást követően oszlopkromatográfiával tisztítjuk, 40\% EtOAc/hexán eluenst alkalmazva.

\subsubsection{Fluoreszcens jelölés ösztrán vázon - A 3.5. fejezetben tárgyalt reakciók leírása}

4.2.5.1. A terminális alkin funkciót tartalmazó BODIPY származék szintézise - A 3.5.1. fejezetben tárgyalt reakciók leírása

\section{Terminális alkin funkció beépitése}

A 4-hidroxi-benzaldehidet (170) (12,22 g, $10.0 \mathrm{mmol})$ feloldjuk acetonban (100 ml), majd propargil-bromidot $\left(1,7 \mathrm{ml}, 80 \%\right.$-os oldat toluolban) és $\mathrm{K}_{2} \mathrm{CO}_{3}$-ot $(9.68 \mathrm{~g}, 70 \mathrm{mmol})$ adunk hozzá. Az elegyet $70^{\circ} \mathrm{C}$-on 24 órán keresztül hagyjuk keveredni. Az oldószert bepárlással eltávolítjuk, majd a nyersterméket (171) oszlopkromatográfiásan tisztítjuk, 20\% $\mathrm{CH}_{2} \mathrm{Cl}_{2} /$ hexán eluens alkalmazásával. 


\section{A dipirrometán elöállítása}

A 4-(prop-2-iniloxi)-benzaldehidhez (171) $(0,48 \mathrm{~g}, 3 \mathrm{mmol})$ hozzáadjuk a pirrolt $(9 \mathrm{ml}, 1,29$ mmol), a TFA-t ( $24 \mu 1,0,3 \mathrm{mmol}$ ) és szobahőmérsékleten keverjük 10 percig, $\mathrm{N}_{2}$ atmoszféra

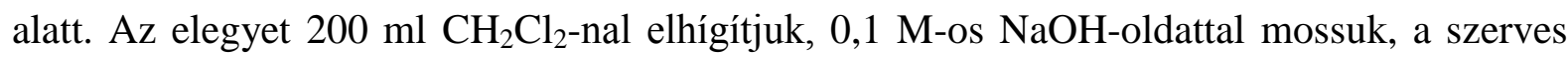
fázist izzított nátrium-szulfáton szárítjuk és bepároljuk. A vákuumbepárlás során az elreagálatlan pirrol nagy része is távozik. A nyersterméket (172) oszlopkromatográfiásan tisztítjuk, alufóliával bevont oszlopon, hexán/EtOAc/ $\mathrm{Et}_{3} \mathrm{~N}$ 80/20/1 arányú elegyének alkalmazásával.

\section{A dipirrometán oxidálása és a komplexálás}

A dipirrometánt (173) (0,6 g, 2,2 mmol) száraz $\mathrm{CH}_{2} \mathrm{Cl}_{2}$-ban $(30 \mathrm{ml})$ oldjuk, és hozzáadjuk a DDQ-t (0,49 g, 2,2 mmol). Szobahőmérsékleten történő 1 órás kevertetés után hozzáadjuk a $\mathrm{Et}_{3} \mathrm{~N}$-t $(2 \mathrm{ml}, 14,4 \mathrm{mmol}), \mathrm{a} \mathrm{BF}_{3} \mathrm{Et}_{2} \mathrm{O}$-ot $(2,3 \mathrm{ml}, 8,6 \mathrm{mmol})$, és további 4 órán keresztül keverjük $\mathrm{N}_{2}$ atmoszféra alatt. A reakciót $25 \mathrm{ml}$ telített $\mathrm{NaHCO}_{3}$ oldat hozzáadásával állítjuk le. A szerves fázist elválasztjuk és izzított $\mathrm{Na}_{2} \mathrm{SO}_{4}$-on szárítjuk. Bepárlás után a nyersterméket (174) oszlopkromatográfiásan tisztítjuk, 20\% EtOAc/hexán eluens alkalmazásával.

\subsubsection{A BODIPY-azid elöállitása - A 3.5.2. fejezetben tárgyalt reakciók leírása}

\section{A BODIPY-bromid elöállitása}

Az 5-brómvaleriánsavat (175) $(0,76 \mathrm{~g}, 4,2 \mathrm{mmol})$ feloldjuk száraz $\mathrm{CH}_{2} \mathrm{Cl}_{2}$-ban $(20 \mathrm{ml})$, hozzáadunk 3 csepp DMF-ot és az oxalil-kloridot $(0,5 \mathrm{ml}, 5,8 \mathrm{mmol})$. Szobahőmérsékleten kevertetjük 3 órán át, majd 3-szor $15 \mathrm{ml}$ toluollal bepároljuk. Az így nyert savklorid nyersterméket (176) $\mathrm{N}_{2}$ atmoszféra alatt feloldjuk száraz $\mathrm{CH}_{2} \mathrm{Cl}_{2}$-ban $(20 \mathrm{ml})$, és a savklorid $\mathrm{CH}_{2} \mathrm{Cl}_{2}$-os oldatát adagoljuk a 3-etil-2,4-dimetilpirrol (1,23 g, 10,0 mmol) $\mathrm{CH}_{2} \mathrm{Cl}_{2}$-os (20 ml) oldatához. Az elegyet 4 órán keresztül forraljuk. Szobahőmérsékletre hütés után, hozzáadjuk a $\mathrm{Et}_{3} \mathrm{~N}$-t $(11 \mathrm{ml}, 80 \mathrm{mmol})$, és újabb 30 percig forraljuk. Végül hozzáadjuk a $\mathrm{BF}_{3} \mathrm{Et}_{2} \mathrm{O}$-ot (10 $\mathrm{ml}, 80 \mathrm{mmol}$ ), és 3 órán át ismét forraljuk. Szobahőmérsékletre hütést követően $30 \mathrm{ml}$ telített 
$\mathrm{NaHCO}_{3}$ oldatot adunk a reakcióelegyhez és 3 x $20 \mathrm{ml} \mathrm{CH}_{2} \mathrm{Cl}_{2}$-nal extraháljuk. Az egyesített szerves fázisokat izzított $\mathrm{Na}_{2} \mathrm{SO}_{4}$-on szárítjuk és bepároljuk. A brómszármazékot (178) oszlopkromatográfiával tisztítjuk 10\% EtOAc/hexán eluens alkalmazásával.

\section{A BODIPY-azid elöállitása}

A BODIPY-brómvegyületet (178) (878 mg, 2,0 mmol) feloldjuk DMSO-ban (5 ml), hozzáadunk 3 csepp $\mathrm{CH}_{3} \mathrm{COOH}$-t és a $\mathrm{NaN}_{3}$-ot $(130 \mathrm{mg}, \quad 2,0$ mmol$)$, majd szobahőmérsékleten keverjük 30 percig. A reakcióelegyet vízreöntjük, 3 x $20 \mathrm{ml} \mathrm{CH}_{2} \mathrm{Cl}_{2}$-nal extraháljuk, az egyesített szerves fázisokat izzított $\mathrm{Na}_{2} \mathrm{SO}_{4}$-on szárítjuk, majd bepároljuk. $\mathrm{A}$ nyersterméket (179) oszlopkromatográfiásan tisztítjuk 10\% EtOAc/hexán eluens alkalmazásával.

4.2.5.3. Azid vagy alkin funkció kiépitése a szterán vázon - A 3.5.3. fejezetben tárgyalt reakciók leírása

\section{A fenolos hidroxilcsoport acetilezése}

Az ösztront $(2(\mathrm{H}))(4,85 \mathrm{~g}, 18,0 \mathrm{mmol})$ piridinben oldjuk $(10 \mathrm{ml})$, és $\mathrm{Ac}_{2} \mathrm{O}$-et $(10 \mathrm{ml}, 106,7$ mmol) adunk hozzá. Az elegyet szobahőmérsékleten 2 órán keresztül hagyjuk keveredni. A reakció lejátszódása után a reakcióelegyet vízre öntjük és a kivált csapadékot szürjük, majd szárítjuk. Az így nyert terméket (2(Ac)) tisztítás nélkül alakítjuk tovább.

\section{A ketál védöcsoport kialakitása}

Az ösztron-3-acetáthoz (2(Ac)) (13,75 g, 44 mmol) hozzáadjuk az ortohangyasavtrietilésztert ( $15 \mathrm{ml}, 88 \mathrm{mmol})$, az etilénglikolt ( $6 \mathrm{ml}, 110 \mathrm{mmol})$ és a katalitikus mennyiségü p-TsOH-at. Az elegyet enyhe melegítés mellett addig kevertetjük, amíg fel nem tisztul (kb. 30 perc). A reakció lejátszódása után a még meleg reakcióelegyet $100 \mathrm{ml}$ telített nátriumhidrogénkarbonát oldatra öntjük. A fehér csapadékot szürjük, mossuk vízzel, és levegőn szárítjuk. A nyersterméket (180) (10,70 g, 30 mmol) 100 ml száraz THF-ban oldjuk, majd hozzáadjuk a piridínium-hidrobromid-perbromidot $(10 \mathrm{~g}, 30 \mathrm{mmol})$. A sárga oldatból fehér csapadék kiválását tapasztaljuk. A reakcióelegyet további 2 órán keresztül kevertetjük, majd 
elhígítjuk $500 \mathrm{ml}$ telített $\mathrm{NaHCO}_{3}$ oldattal. A fehér csapadékot szürjük, majd mossuk vízzel és levegőn szárítjuk. Az így nyert terméket (181) tisztítás nélkül alakítjuk tovább.

Az $\alpha, \beta$-telítetlen ketál elöállitása

A brómketált (181) (4,35 g, $10 \mathrm{mmol})$ feloldjuk DMSO-ban $(50 \mathrm{ml})$, hozzáadjuk a KO ${ }^{t} \mathrm{BU}$-ot $(2,24 \mathrm{~g}, 20 \mathrm{mmol})$ és $80^{\circ} \mathrm{C}$-on intenzíven kevertetjük, amíg tiszta sárgás-barna oldatot kapunk (5 óra). Ezután 1 liter jeges vízre öntjük, szürjük, vízzel mossuk és a csapadékot levegőn szárítjuk. A nyersterméket (182) oszlopkromatográfiával tisztítjuk, $\mathrm{CH}_{2} \mathrm{Cl}_{2}$ eluenssel.

\section{Az $\alpha, \beta$-telítetlen keton elöállítása}

Az $\alpha, \beta$-telítetlen ketált (182) (1,25 g, 4,0 mmol) feloldjuk acetonban $(25 \mathrm{ml})$, és $40 \%$-os vizes formalint ( $5 \mathrm{ml}, 60 \mathrm{mmol}$ formaldehid), majd katalitikus mennyiségü $p$-TsOH-at adunk hozzá. Hagyjuk szobahőmérsékleten keveredni 1,5 órán át, $100 \mathrm{ml}$ vízzel elhígítjuk, a kivált csapadékot szürjük, és levegőn szárítjuk. A nyersterméket (183) oszlopkromatográfiával tisztítjuk 2\% EtOAc/ $\mathrm{CH}_{2} \mathrm{Cl}_{2}$ eluenssel.

\section{Azidálás a 15-ös helyzetben}

Az $\alpha, \beta$-telítetlen ketont (ösztra-1,3,5(10),15-tetraén-17-on, (183) (268 g, 1,0 mmol), feloldjuk DMSO-ban (5 ml) hozzáadjuk az $\mathrm{CH}_{3} \mathrm{COOH}$-at $(0,24 \mathrm{ml}, 4,0 \mathrm{mmol})$ és a $\mathrm{NaN}_{3}$-ot $(65 \mathrm{mg}$, $1,0 \mathrm{mmol}$ ). Szobahőmérsékleten kevertetjük 30 percig, majd $50 \mathrm{ml}$ víz hozzáadásával

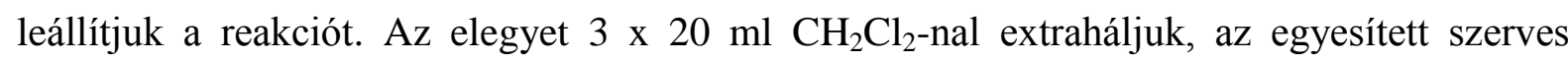
fázisokat izzított $\mathrm{Na}_{2} \mathrm{SO}_{4}$-on szárítjuk, majd bepároljuk. A nyersterméket (184) oszlopkromatográfiával tisztítjuk, eluensként $10 \%$ EtOAc/ $\mathrm{CH}_{2} \mathrm{Cl}_{2}$ eluenssel.

\section{O-propargilezés a 15-ös helyzetben}

Az $\alpha, \beta$-telítetlen ketont (183) (268 mg, 1,0 mmol) feloldjuk diklórmetánban (15 ml), hozzáadjuk a propargil-alkoholt $(3,6 \mathrm{ml})$, és 5 csepp $5 \%$-os $\mathrm{NaOH}$ oldatot. Szobahőmérsékleten kevertetjük 24 órán át, majd $150 \mathrm{ml}$ víz hozzáadásával leállítjuk a 
reakciót. Az elegyet 3 x $20 \mathrm{ml} \mathrm{CH}_{2} \mathrm{Cl}_{2}$-nal extraháljuk, egyesített szerves fázisokat izzított $\mathrm{Na}_{2} \mathrm{SO}_{4}$-on szárítjuk, majd bepároljuk. A nyersterméket (184) oszlopkromatográfiával tisztítjuk, eluensként $\mathrm{CH}_{2} \mathrm{Cl}_{2}$-t alkalmazva.

\section{Sonogashira kapcsolás 13ß-ösztrán vázon a 2-es helyzetben}

Mikrohullámú reaktorhoz használatos reakcióedényben a megfelelő jódszármazékhoz (3hidroxi-2-jód-ösztra-1,3,5(10)-trién-17-on (7(H)) (276 mg, 1,0 mmol) rendre hozzáadjuk a 10 $\mathrm{mol} \% \mathrm{Pd}\left(\mathrm{PPh}_{3}\right)_{4}$ katalizátort (115 mg, 0,01 mmol) és a $10 \mathrm{~mol} \% \mathrm{CuI}$-ot (19 mg, 0,01 mmol) $3 \mathrm{ml}$ THF oldószert és a $\mathrm{Et}_{3} \mathrm{~N}-\mathrm{t}(0,56 \mathrm{ml}, 4,0 \mathrm{mmol})$ és $\mathrm{N}_{2}$ atmoszféra alatt, $50{ }^{\circ} \mathrm{C}$-on 10 percig előkevertetjük. Ezután adjuk hozzá a 2 ekvivalens trimetilszilil-acetilént $(0,28 \mathrm{ml}, 2,0$ mmol). A reakció $50{ }^{\circ} \mathrm{C}$-on, CEM mikrohullámú reaktor alkalmazásával, 20 perc alatt játszódik le. A reakcióelegyet közvetlenül szilikagélre pároljuk. A nyersterméket (186) oszlopkromatográfiával tisztítjuk, 50\% diizopropil-éter/hexán eluens alkalmazásával.

4.2.5.4. Fluoreszcens jelölés CuAAC reakcióban - A 3.5.4. fejezetben tárgyalt reakciók leírása

Az 15-ös helyzetben jelölt vegyületek elöállitása CuAAC reakcióval

Az ösztron-azidhoz (15 $\beta$-azido-ösztra-1,3,5(10)-trién-17-on, 184) $322 \mathrm{mg}, 1,0 \mathrm{mmol}$ ) vagy ösztron-alkinhez (15 $\beta$-O-propargil-ösztra-1,3,5(10)-trién-17-on, 185) (324 mg, 1,0 mmol) feloldjuk toluolban (5 ml), hozzáadjuk a $\mathrm{PPh}_{3}$-t $(26 \mathrm{mg}, 0,05 \mathrm{mmol})$, a CuI-ot $(9,5 \mathrm{mg}, 0,05$ mmol), a DIPEA-t (0,52 ml, 3,0 mmol) majd a megfelelő a BODIPY-alkint (174) (0,025 g, 0,08 mmol) vagy BODIPY-azidot (179) $(40 \mathrm{mg}, 0,96 \mathrm{mmol})$ és 2 órán át forraljuk. Szobahőmérsékletre hütést és bepárlást követően a nyersterméket $(\mathbf{1 8 8} ; \mathbf{1 8 9})$ oszlopkromatográfiával tisztítjuk, eluensként $10 \%$ EtOAc/ $\mathrm{CH}_{2} \mathrm{Cl}_{2}$ elegyét alkalmazva.

\section{Az, 2-es helyzetben jelölt vegyületek elöállitása CuAAC reakcióval}

Az ösztron-alkint (2-trimetilszililetinil-ösztra-1,3,5(10)-trién-17-on, 186) (367 mg, 1,0 mmol) feloldjuk toluolban (3 ml) hozzáadjuk a $\mathrm{PPh}_{3}$-t $(26 \mathrm{mg}, 0,1 \mathrm{mmol})$, a CuI-ot $(9,5 \mathrm{mg}, 0,05$ mmol) a DIPEA-t (0,52 ml, 3,0 mmol) és a BODIPY-azidot (179) (40 mg, 0,96 mmol), majd 
a reakcióelegyet a reflux hőmérsékletére emeljük és hozzáadjuk a TBAF-ot (1 ml, 1,0 mmol), majd további 2 óráig forraljuk. Szobahőmérsékletre hütést és bepárlást követően a nyersterméket (191) oszlopkromatográfiával tisztítjuk, eluensként $10 \%$ EtOAc/ $\mathrm{CH}_{2} \mathrm{Cl}_{2}$ elegyét alkalmazva. 


\section{5. Összefoglalás}

Munkánk kezdeti szakaszában halogénezési reakciókat végeztünk a $13 \alpha$-ösztron kiválasztott származékain. A 13a-ösztronból és 3-O-metil vagy 3-O-benzil származékaiból kiindulva, $N$ jód-, $N$-bróm- vagy $N$-klórszukcinimiddel, sikeresen állítottunk elő A-gyürüben halogénezett vegyületeket (I. ábra). A 2- és/vagyés -4-szubsztituált valamint 2,4-bisz származékok rövid reakcióidővel, jó hozammal képződtek. A halogénezési reakciók során az oldószer és a reaktáns mennyiségének változtatása egyes esetekben jelentősen befolyásolta a képződő termékek arányát. A fenolos hidroxilcsoport jelenléte nemcsak az egyszeres, hanem a kétszeres szubsztitúciónak is kedvezett. A 3-védett vegyületek esetében csak monoszubsztituált származékok képződtek és a 3-benziléter bizonyult a legkevésbé reaktívnak. Ebből kiindulva csak a brómozás és a klórozás volt megvalósítható, a jódozás viszont nem. A 17-dezoxi-13 $\alpha$-ösztron $N$-haloszukcinimidekkel történő halogénezési reakciói is 2- és/vagyés 4-szubsztituált valamint 2,4-bisz-származékokhoz vezettek. Összehasonlítottuk a 17-oxo és 17-dezoxi pár azonos körülmények között végrehajtott reakcióit és azt tapasztaltuk, hogy a megfelelő termékek különböző arányban képződtek. A 17-dezoxi sorban egyes esetekben csupán az alkalmazott körülmények jelentős megváltoztatásával sikerült a célvegyületeket előállítani.

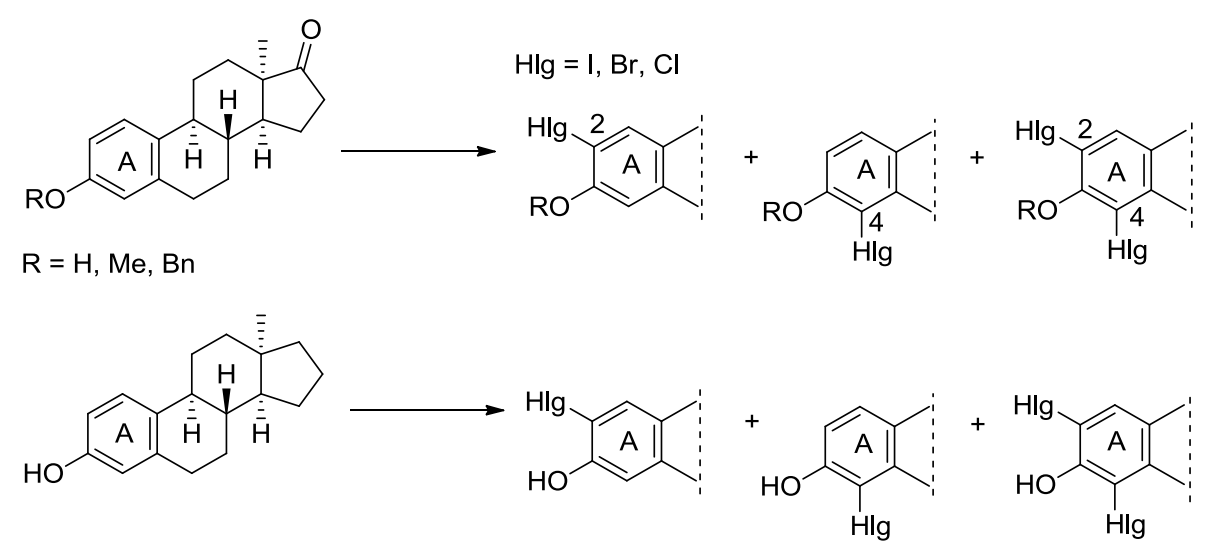

I. ábra

Hatékony mikrohullámú eljárást dolgoztunk ki a kapott halogénvegyületek Sonogashira keresztkapcsolására. A 2-jód-3-O-metil-13 $\alpha$-ösztron (II. ábra) fenil-acetilénnel lejátszódó reakciója dimetil-formamidos közegben, $\mathrm{Pd}\left(\mathrm{PPh}_{3}\right)_{4}$ katalizátorral, CuI segédkatalizátorral, trietil-amin bázis jelenlétében, mikrohullámú besugárzással, $50{ }^{\circ} \mathrm{C}$-on, 20 perc alatt lejátszódott. A fenil-acetilénre optimalizált módszernél az oldószert acetonitrilre cserélve sikeresen végrehajtottuk a 3-as helyzetben szabad fenolos hidroxilcsoportot tartalmazó vegyület reakcióját is. Az eljárást kiterjesztettük a 4-jód vegyületekre is. Azt tapasztaltuk, 
hogy a hőmérséklet $80^{\circ} \mathrm{C}$-ra emelése és a katalizátor $\mathrm{Pd}\left(\mathrm{PPh}_{3}\right)_{2} \mathrm{Cl}_{2}$-ra történő cseréje elősegíti a 4-es helyzetü szubsztitúciót. A szabad fenolos hidroxilcsoportot tartalmazó jódvegyület szintézisénél a reakcióközeget tetrahidrofuránra cseréltük. A kívánt termékeket rövid reakcióidő alatt, kiváló hozammal sikerült előállítanunk. A fenil-acetilénre kidolgozott módszer jól alkalmazható volt a különböző 4'-szubsztituenst tartalmazó $\left(\mathrm{C}_{6} \mathrm{H}_{5} \mathrm{R}^{2}\right)$ fenetinil származékok előállítására is.

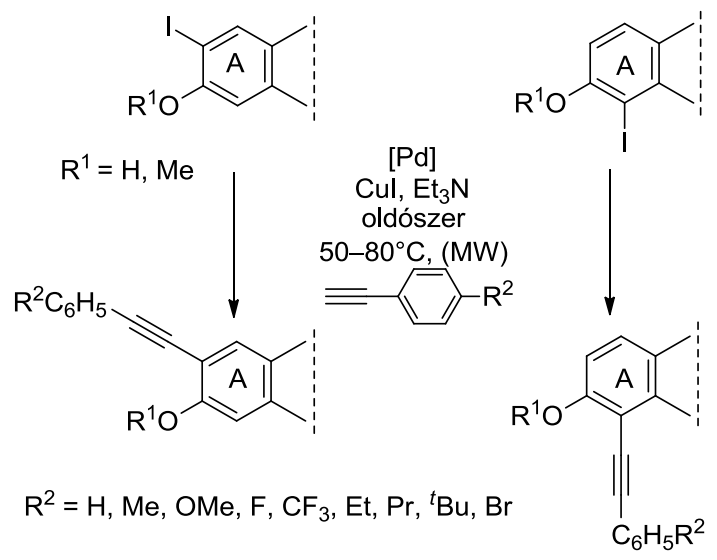

II. ábra

A Sonogashira-kapcsolással előállított fenetinil-származékokat transzfer hidrogénezésnek vetettük alá. Mikrohullámú besugárzás alkalmazásával megvalósítottuk a 4'(metoxifenil)etinil származékok $\mathrm{C} \equiv \mathrm{C}$ kötésének részleges telítését a 3-metiléter sorban (III. ábra). Hidrogénforrásként $\mathrm{DMF} / \mathrm{KOH}$ rendszert, katalizátorként pedig $\mathrm{Pd}\left(\mathrm{PPh}_{3}\right)_{2} \mathrm{Cl}_{2}$-ot használtunk. A 2-fenetinil származékból kemo- és sztereoszelektív módon cisz-alkenil, míg a 4-es regioizomerből transz-alkenil származék képződött. A 3-hidroxi származékok a transzfer hidrogénezés körülményei között nem a 2- vagy 4-fenetenil származékokat szolgáltatták. Megállapítottuk azonban, hogy ilyen körülmények között gyürüzárási reakcióban benzo[b]furán molekularészletet tartalmazó, új vegyületekké alakulnak. A 2- vagy 4-fenetinil származékokat $\mathrm{Pd} / \mathrm{C}$ jelenlétében, etil-acetát oldószerben, 20 bar hidrogénnyomás alatt kiváló hozammal alakítottuk 2- vagy 4-fenetil származékokká. 


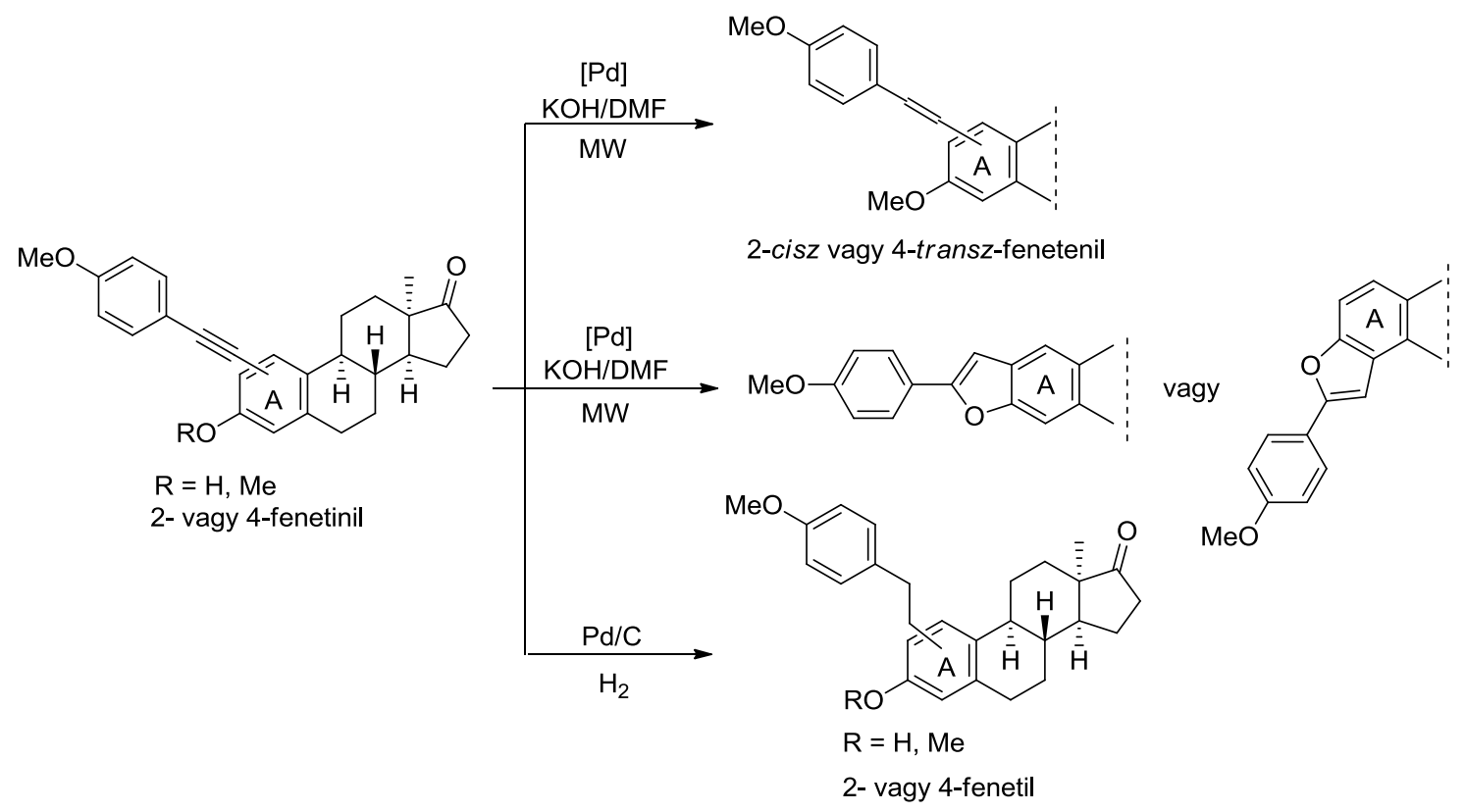

III. ábra

Az A-gyürüben halogénezett származékokat nem csak $\mathrm{C}-\mathrm{C}$, hanem $\mathrm{C}-\mathrm{N}$ kapcsolási reakciónak is alávetettük. Hatékony Buchwald-Hartwig keresztkapcsolási eljárást dolgoztunk ki a 2-bróm-3-O-metil-13 $\alpha$-ösztron anilinnel történő aminálására (IV. ábra). Az optimalizálás során a palládiumkatalizátort, a ligandumot és a bázist változtattuk. Összehasonlítottuk a hagyományos melegítéssel és a mikrohullám alkalmazásával végrehajtott folyamatok lefutását. Megállapítottuk, hogy az utóbbi eljárás jelentősen csökkenti a reakcióidőt. A legmagasabb hozamot $\mathrm{Pd}(\mathrm{OAc})_{2}$ katalizátor, $\mathrm{KO}^{t} \mathrm{Bu}$ bázis és XPhos segédligandum $100{ }^{\circ} \mathrm{C}$ on mikrohullámú reaktor alkalmazásával értük el. Az anilinre kidolgozott módszert kiterjesztettük különböző elektronikus tulajdonságú orto, meta és para szubsztituenssel rendelkező monoszubsztituált anilinekre is. A szubsztituált fenilamino vegyületeket magas hozamokkal nyertük. Megfigyeltük, hogy a szubsztituensek helyzete nem, azok elektronikus sajátságai azonban enyhén befolyásolják a konverziót.

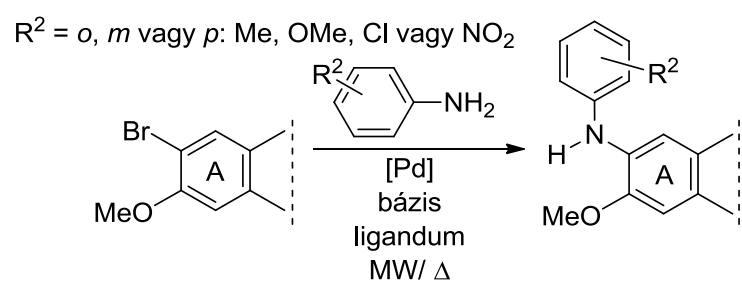

IV. ábra

A 2-es helyzetű kapcsolásra kidolgozott módszer a 4-bróm-3-O-metil- és a 2- és 4-bróm-3-Obenzil-13 $\alpha$-ösztronra változtatás nélkül alkalmazható volt (V. ábra). 
2 vagy 4

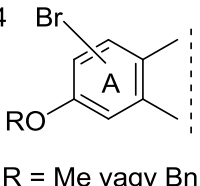

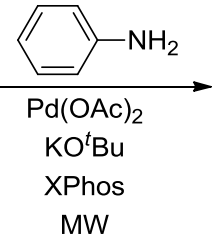

MW

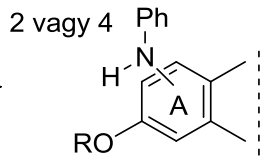

$\mathrm{R}=$ Me vagy $\mathrm{Bn}$

V. ábra

Annak érdekében, hogy 2- és 4-amino-származékokat képezzünk, anilin helyett benzofenoniminnel is elvégeztük a kapcsolást (VI. ábra). A 2- és 4- $N$-difenilmetilidénamino-13 $\alpha$-ösztront egy további reakciólépésben hatékonyan átalakítottuk a megfelelő amino származékokká. Az $\mathrm{NH}_{2}$ csoport felszabadítását a 3-metiléterek esetében erős Brønsted savval, míg a 3-benziléter származékból Pd-katalizált hidrogenolízissel végeztük.

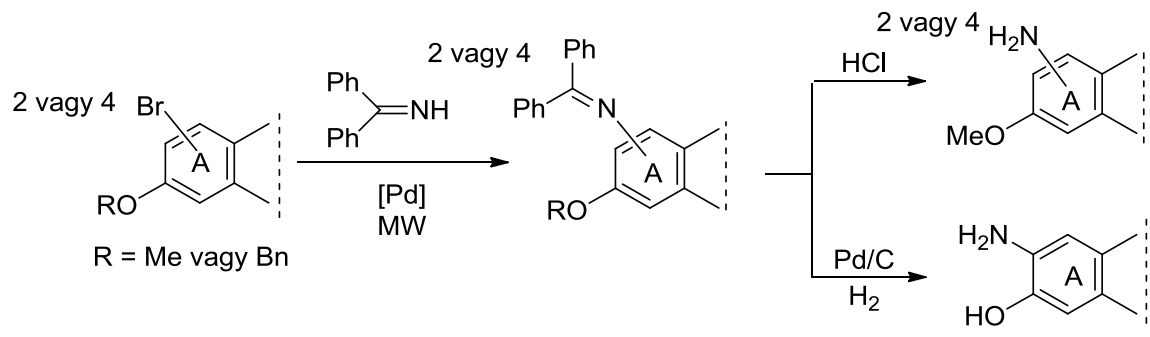

VI. ábra

Munkánk záró szakaszában BODIPY-alapú festékkel fluoreszcensen jelölt ösztron származékokat állítottunk elő CuAAC konjugálással. Ehhez szükségünk volt olyan BODIPY festékekre és ösztron származékokra, amelyek azid vagy alkin funkciót tartalmaznak. Az ösztron jelölését az A- (C-2) és D-gyürün (C-15) keresztül is megvalósítottuk. Az új BODIPY-alapú fluoreszcens azidot a triszubsztituált pirrol $\omega$-bróm-valeriánsavból in situ kialakított savklorid származékával történő kondenzációjával állítottuk elő. A bróm-BODIPYt az intermedier izolálása nélkül bór-trifluorid-dietil-éter komplex és bázis alkalmazásával nyertük. A BODIPY-azidhoz a brómvegyületből bróm-azid cserereakcióban jutottunk (VII. ábra).

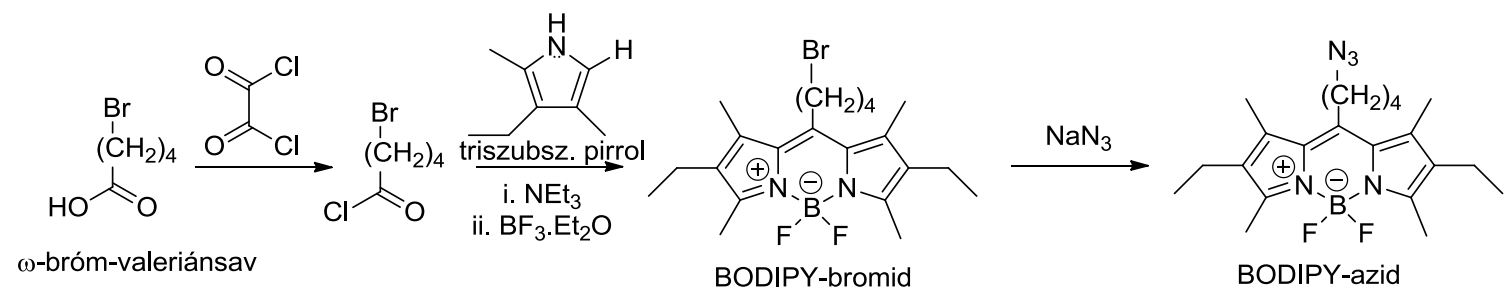

VII. ábra

Az ösztron-azid vagy ösztron-alkin elöállításához a $\Delta^{15,16}$-ösztronból kiindulva, Michaeladdícióval azid vagy $O$-propargil nukleofilt építettünk be a 15 -ös szénatomra (VIII. ábra). A 
nukleofil támadása sztereoszelektív módon, a $15 \beta$ helyzetböl következett be, $15 \beta$-azido és 15 $\beta$-O-propargil származékot szolgáltatva. Az etinilcsoportot beépítettük az A-gyürübe is, a 2-es szénatomra. Először alkin reakciópartnerként trimetilszilil-acetilént alkalmazva Sonogashira kapcsolást végeztünk az általunk kidolgozott mikrohullámú módszerrel. A trimetilszilil védőcsoportot a CuAAC reakció során in situ lehasítottuk. A szükséges azidok és alkinek birtokában végrehajtottuk a BODIPY-festékek szteroidokhoz történő konjugálását. A CuAAC reakciókban, hagyományos melegítéssel, rövid reakcióidő alatt kiváló hozammal nyertük a kívánt konjugátumokat.

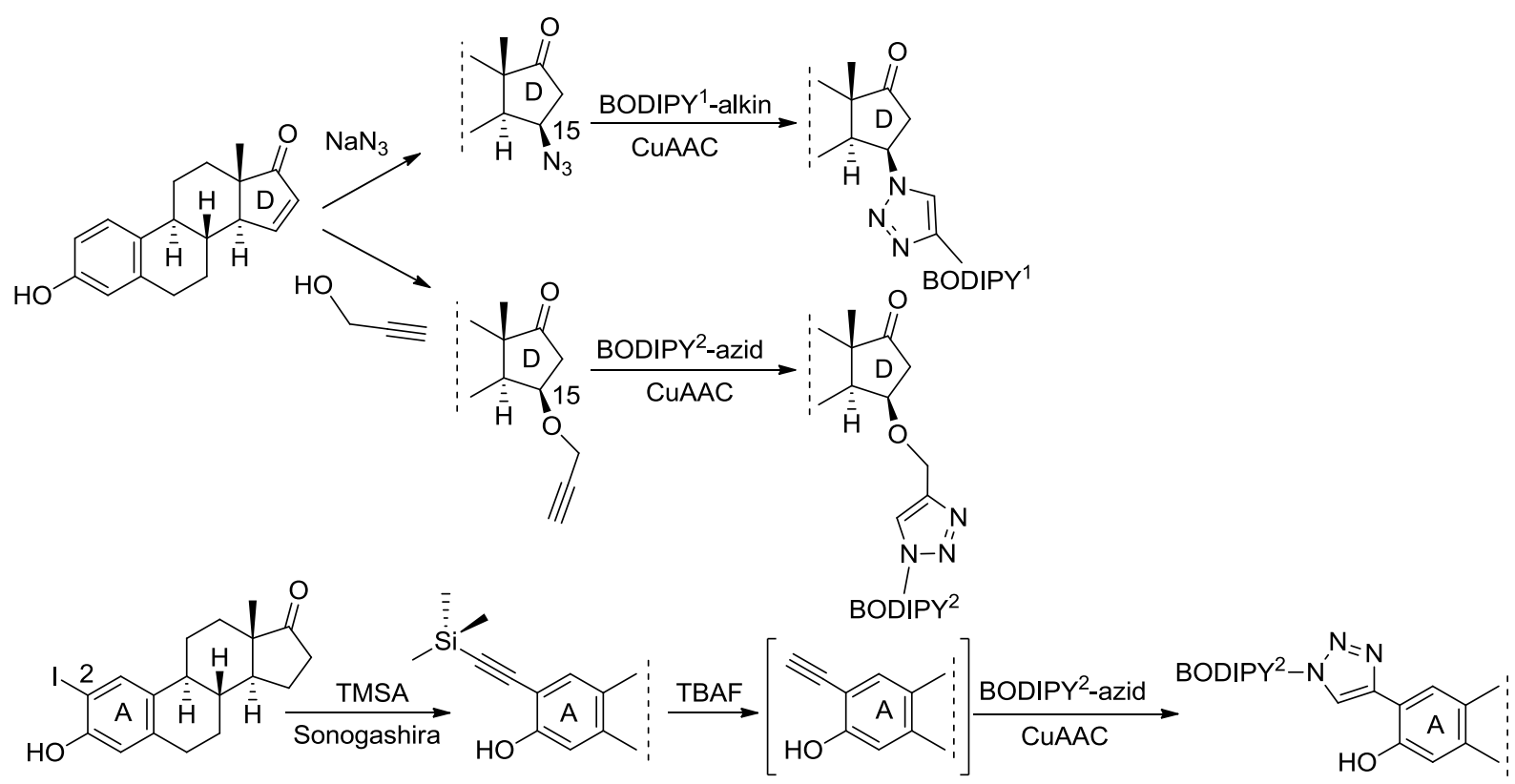

VIII. ábra

Munkánk során számos olyan új 13a-ösztron származékot állítottunk elő, amelyek tumorellenes hatással rendelkeznek. Egyes A-gyürüben szubsztituált új vegyületeink hatékonyan gátolják bizonyos, az ösztrogén bioszintézisben kulcsszerepet játszó enzimek müködését. Sikerült továbbá olyan új fluoreszcensen jelölt ösztron származékokat is képeznünk, amelyek alapot adhatnak a fluoreszcencia mérésén alapuló biokémiai eljárások kidolgozásához. 


\section{Summary}

Our work was started with the aromatic halogenation of 13a-estrone. 3-O-Methyl- and 3-Obenzyl-protected $13 \alpha$-estrone were successfully reacted with $\mathrm{N}$-iodo-, $\mathrm{N}$-bromo- or $\mathrm{N}$ chlorosuccinimide to afford 2-, 4- and 2,4-bis-substituted derivatives at ring A (Scheme I). These were formed in short reaction times and good yields. Conversions could be significantly influenced by changing the solvent of the reaction and varying the quantity of the reactant. The presence of the phenolic $\mathrm{OH}$ group facilitates both mono- and double substitution. 3-Protected compounds yielded only monosubstituted derivatives. The 3-Obenzyl ether showed reduced reactivity, only bromination and chlorination occurred in this case. Similar halogenations of 17-deoxy-13a-estrone with $N$-halosuccinimide were carried out to synthesize 2-, 4- and 2,4-bis-substituted derivatives. A comparison of the results obtained in the halogenation of 17-oxo and 17-deoxy starting compounds allowed the conclusion that analogous derivatives were formed in different ratios. In the 17-deoxy series in some cases major changes in conditions were required to have the desired compounds.

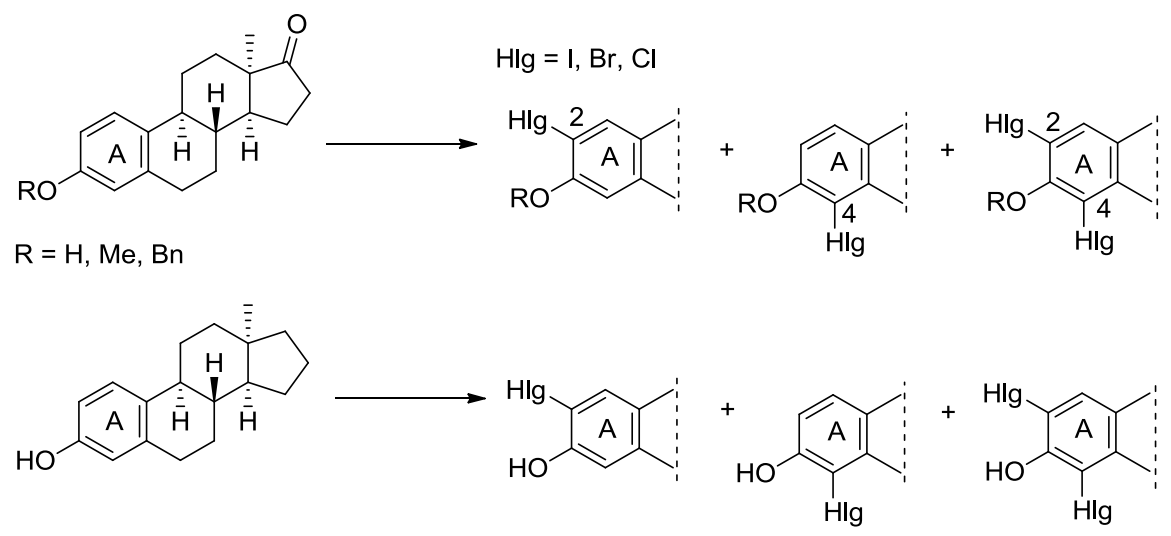

Scheme I

We have developed a convenient synthetic microwave procedure for Sonogashira coupling using the synthesized halogen compounds as starting materials. The reaction of 2-iodo-3-Omethyl-13 $\alpha$-estrone with phenylacetylene could efficiently be achieved using $\operatorname{Pd}\left(\mathrm{PPh}_{3}\right)_{4}$ catalyst and $\mathrm{CuI}$ cocatalyst in dimethylformamide in the presence of $\mathrm{Et}_{3} \mathrm{~N}$ as a base, at $50{ }^{\circ} \mathrm{C}$ in $20 \mathrm{~min}$ in a microwave reactor (Scheme II). After establishing the most favourable reaction conditions using phenylacetylene as the alkyne partner, the method was successfully adapted to compounds with phenolic 3-OH function by the change of solvent to acetonitrile. We extended the scope of the steroid component to 4-iodo derivatives. We found that elevation of the reaction temperature to $80{ }^{\circ} \mathrm{C}$ and the change of catalyst to $\mathrm{Pd}\left(\mathrm{PPh}_{3}\right)_{2} \mathrm{Cl}_{2}$ facilitated substitution at $\mathrm{C}-4$. Iodo compounds bearing phenolic $\mathrm{OH}$ required the changing of solvent to 
tetrahydrofuran. We isolated the desired 4-phenethynyl compound in short time and excellent yield. The protocol developed for phenylacetylene was successfully extended to the synthesis of 4-(4'-subst.)phenethynyl derivatives.

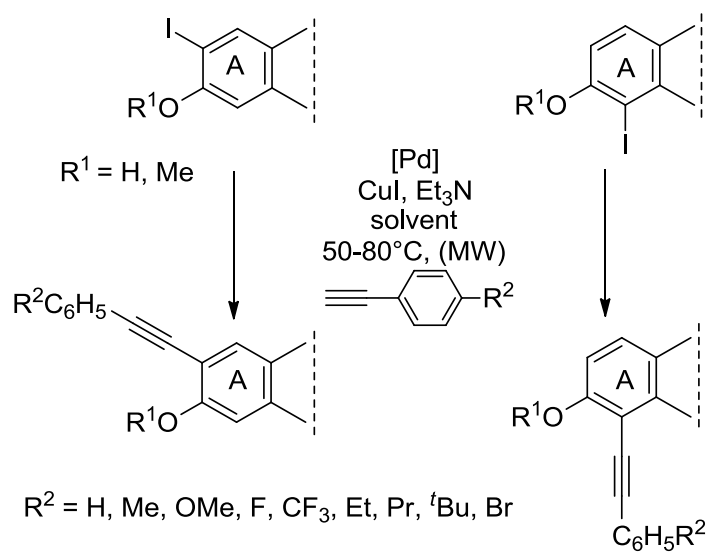

Scheme II

We carried out the semihydrogenation of certain compounds synthesized by Sonogashira coupling. Microwave-assisted partial saturation of (4'-methoxyphenyl)ethynyl compounds was achieved in the 3-methyl ether series. We applied $\mathrm{DMF} / \mathrm{KOH}$ as the hydrogen source and $\mathrm{Pd}\left(\mathrm{PPh}_{3}\right)_{2} \mathrm{Cl}_{2}$ as the catalyst. Under the applied conditions, cis-alkenes were formed from 2phenethynyl derivatives while 4-phenethynyl derivatives led to trans-alkenes chemo- and stereoselectively. Semihydrogenation of compounds bearing phenolic $\mathrm{OH}$ did not result in 2or 4-phenethenyl compounds; rather, formation of benzo[b]furans occurred. Additionally, we transformed 2- and 4-phenethynyl derivatives in ethyl acetate under 20 bar $\mathrm{H}_{2}$ with palladiumon-charcoal to 2- and 4-phenethyl derivatives, respectively, in excellent yields (Scheme III).

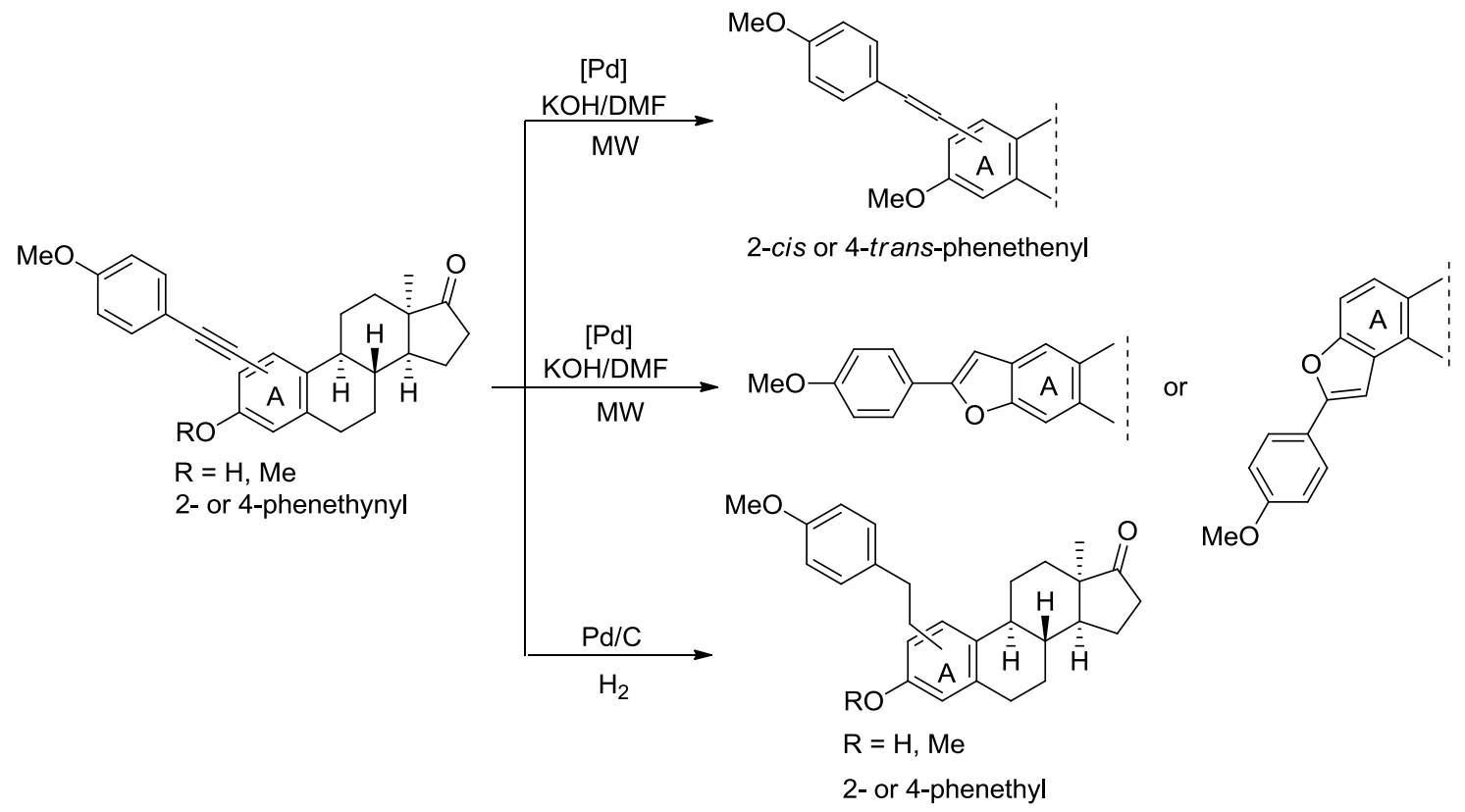

Scheme III 
We performed not only $\mathrm{C}-\mathrm{C}$ but $\mathrm{C}-\mathrm{N}$ cross couplings as well starting from the ring $\mathrm{A}$ halogenated derivatives. We have developed an efficient protocol for the Buchwald-Hartwig amination of 2-bromo-3-O-methyl-13 $\alpha$-estrone with aniline (Scheme IV). An optimization process was performed by the systematic changes of catalyst, base and ancillary ligand. We compared conventional heating and microwave-assisted heat transfer and found that microwave irradiation shortened reaction times significantly. The highest yields were achieved by using $\mathrm{Pd}(\mathrm{OAc})_{2}$ as catalyst, $\mathrm{KO}^{t} \mathrm{Bu}$ as base and XPhos as ancillary ligand at 100 ${ }^{\circ} \mathrm{C}$ in a microwave reactor. With the best reaction conditions in hand, couplings at $\mathrm{C}-2$ were extended to monosubstituted anilines bearing substituents at ortho, meta or para positions with varied electronic properties. All couplings proceeded with high yields. We noticed that the electronic nature of the substituents influenced the conversion slightly but their position did not have any effect.

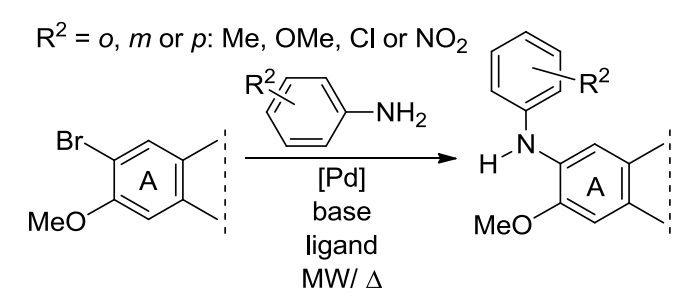

Scheme IV

4-Bromo-3-O-methyl- and 2- or 4-bromo-3-O-benzyl-13 $\alpha$-estrone were successfully aminated with aniline without the need for changing reaction conditions established for couplings at $\mathrm{C}$ 2 (Scheme V).

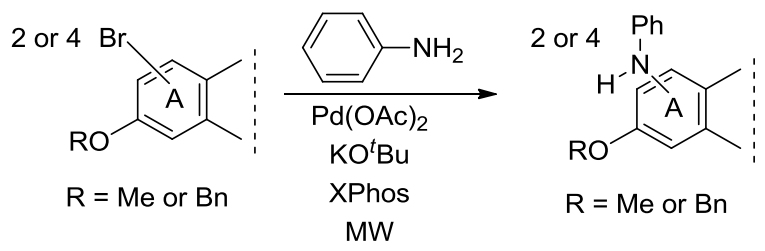

Scheme V

Coupling with benzophenone imine instead of aniline was performed in order to gain 2- or 4amino derivatives (Scheme VI). 2- and 4-( $N$-diphenylmethylideneamino)-13 $\alpha$-estrones were efficiently transformed into the appropriate amino counterparts in a subsequent reaction step. Liberation of the $\mathrm{NH}_{2}$ function was achieved by Brønsted acid in the case of 3-methyl ethers and via hydrogenolysis from the 3-benzyl ether using palladium-on-charcoal catalyst. 


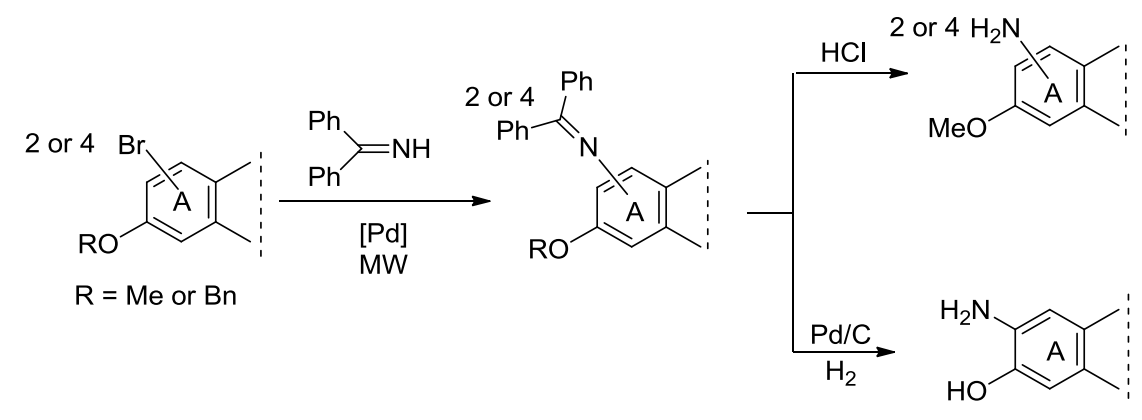

Scheme VI

In the final part of our work we have synthesized BODIPY-based fluorescent estrone conjugates via CuAAC. First, we synthesized estrone derivatives and BODIPY-dyes (BODIPY ${ }^{1}$-alkyne, BODIPY ${ }^{2}$-azide) containing alkyne or azide moiety. We performed the labelling of ring A (at C-2) and ring D (at C-15) of estrone. Novel BODIPY-azide was synthesized via condensation of trisubstituted pyrrole and $\omega$-bromovaleric chloride formed in situ (Scheme VII). Bromo-BODIPY was formed with $\mathrm{BF}_{3} \cdot \mathrm{OEt}_{2}$ and base without the isolation of the intermediate. The new BODIPY-azide was formed in a bromine-to-azide exchange reaction.

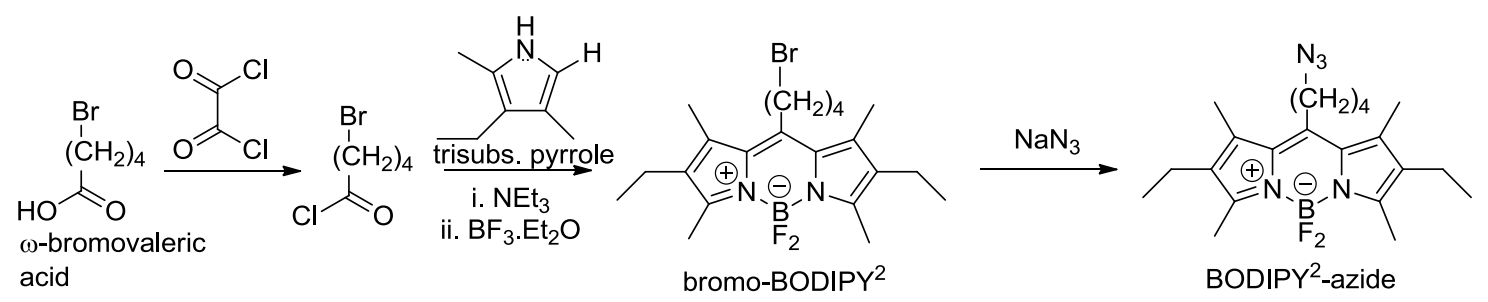

Scheme VII

We carried out Michael addition on $\Delta^{15,16}$ estrone in order to introduce the azide group or $O$ propargyl nucleophile to position 15 (Scheme VIII). The nucleophiles attacked in a stereoselective manner from the $\beta$ direction to $\mathrm{C}-15$ leading to the formation of $15 \beta$-azide and $15 \beta$ - $O$-propargyl derivatives. Additionally, we introduced the ethynyl group onto C-2 by coupling trimethylsilylacetylene (TMSA) via our microwave-assisted protocol established previously. Deprotection was carried out with tetrabutylammonium fluoride (TBAF) in situ during the "click" reaction. With the necessary alkynes and azides in hand, we conjugated the BODIPY dyes with the steroids. CuAAC reactions yielded the desired fluorescent estrone conjugates in short reaction time under conventional heating in good yields. 


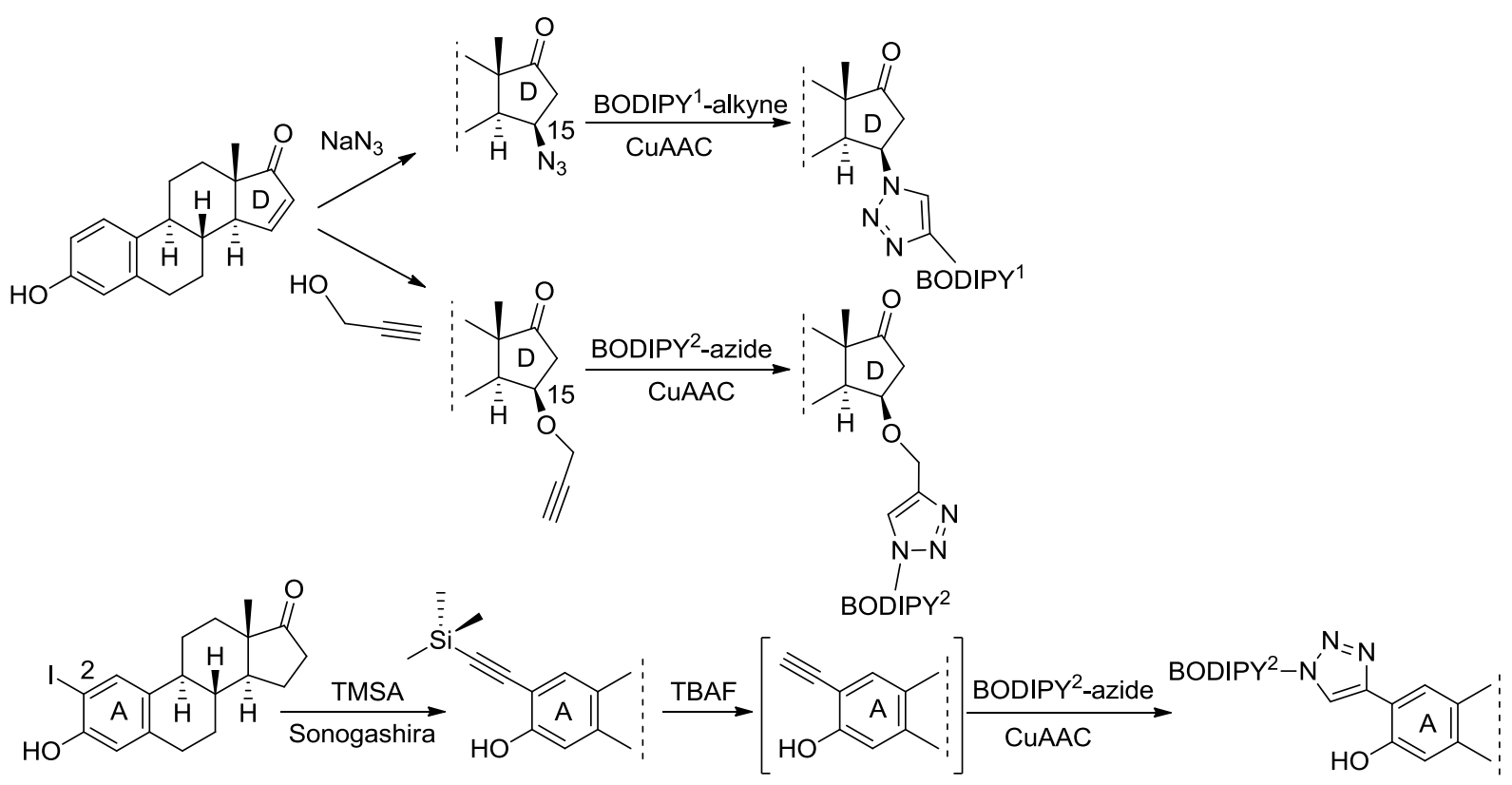

Scheme VIII

We have synthesized several novel potent antitumoral $13 \alpha$-estrone derivatives. Certain new ring A substituted compounds efficiently inhibited the key enzymes of estrogen biosynthesis. We also synthesized novel fluorescent estrone-BODIPY conjugates, which might serve as labelled substrates in the development of fluorescent biochemical assays. 


\section{Irodalomjegyzék}

1. Lumachi F, Brunello A, Maruzzo M, Basso U, Basso S M M. Curr. Med. Chem. 2013, 20, 596 .

2. Thomas M P, Potter B V L. J. Steroid Biochem. Mol. Biol. 2015, 153, 160.

3. Maltais R, Poirier D. Steroids 2011, 76, 929.

4. Gupta A, Kumar B S, Negi A S. J. Steroid Biochem. Mol. Biol. 2013, 137, 242.

5. Chumsri S, Howes T, Bao T, Sabnis G, Brodie A. J. Steroid Biochem. Mol. Biol. 2011, $125,13$.

6. Marchais-Oberwinkler S, Henn C, Möller G, Klein T, Negri M, Oster A, Spadaro A, Werth R, Wetzel M, Xu K, Frotscher M, Hartmann R W, Adamski J. J. Steroid Biochem. Mol. Biol. 2011, 125, 66.

7. Ayan D, Roy J, Maltais R, Poirier D. J. Steroid Biochem. Mol. Biol. 2011, 127, 324.

8. Yaremenko F G, Khvat A. Mendeleev Commun. 1994, 187, 187.

9. Schönecker B, Lange C, Kötteritzsch M, Günther W, Weston J, Anders E, Görls H. J. Org. Chem. 2000, 65, 5487.

10. Wölfling J, Mernyák E, Frank É, Falkay G, Márki Á, Minorics R, Schneider G. Steroids 2003, 68, 277.

11. Minorics R, Bózsity N, Wölfling J, Mernyák E, Schneider G. Márki A, Falkay G, Ocsovszki I, Zupkó I. J. Steroid Biochem. Mol. Biol. 2012, 132, 168.

12. Mernyák E, Kovács I, Minorics R, Sere P, Czégány D, Sinka I, Wölfling J, Schneider G, Újfaludi Zs, Boros I, Ocsovszki I, Varga M, Zupkó I. J. Steroid Biochem. Mol. Biol. 2015, 150, 123.

13. Szabó J, Bacsa I, Wölfling J, Schneider G, Zupkó I, Varga M, Herman B E, Kalmár L, Szécsi M, Mernyák E. J. Enzyme Inhib. Med. Chem. 2016, 4, 574.

14. Berényi Á, Minorics R, Iványi Z, Ocsovszki I, Ducza E, Thole H, Messinger J, Wölfling J, Mótyán G, Mernyák E, Frank É, Schneider G, Zupkó I. Steroids 2013, 78, 69.

15. Mernyák E, Fiser G, Szabó J, Bodnár B, Schneider G, Kovács I, Ocsovszki I, Zupkó I, Wölfling J. Steroids 2014, 8947.

16. Szabó J, Pataki Z, Wölfling J, Schneider G, Bózsity N, Minorics R, Zupkó I, Mernyák E. Steroids 2016, 113, 14.

17. Herman B E, Szabó J, Bacsa I, Wölfling J, Schneider G, Bálint M, Hetényi C, Mernyák E, Szécsi M. J. Enzyme Inhib. Med. Chem. 2016, 31, 61.

18. Numazawa M, Ando M, Watari Y, Tominaga T, Hayata Y, Yoshimura A. J. Steroid Biochem. Mol. Biol. 2005, 96, 51.

19. Phan C M, Liu Y, Kim B M, Mostafa Y, Taylor S D. Bioorg. Med. Chem. 2011, 19, 5999.

20. Boismenu E. Compt. rend. Acad, 1911, 163, 948.

21. A1bert S, Heard R D H, Leb1ond C P, Saffran J, J. Biol. Chem. 1949, 177, 247.

22. Hillmann-Elies A, Hillmann G, Schiedt U. Zeitschrift fuer Naturforschung 1953, 8b, 436. 
23. Numazawa M, Kimura K, Ogata M, Nagaoka M. J. Org. Chem. 1985, 50, 5421.

24. Thomson A J, Horwitz J P., J. Org. Chem. 1959, 24, 2056.

25. Hasrat A, Ghaffari M A,Van Lier J E. J. Steroid Biochem. 1987, $28,21$.

26. Coombs M. M, Jones M. B. Chem. Ind. 1972, 169.

27. Egorova, V. V, Zakharychev, A. V, Ananchenko, S. N. Tetrahedron 1973, 29, 301.

28. Weinreb, A, Werner, A, Lebovitz, Z. Photochem. Photobiol. 1979, 29, 755.

29. Bulman Page P C, Hussain F, Maggs J L, Morgan P, Park B K. Tetrahedron 1990, 46, 2059.

30. Douglas K T, Bunni M A, Baindur S R. Int. J. Biochem. 1990, 22, 429.

31. Castanet A-S, Colobert F, Broutin P-E. Tetrahedron Lett. 2002, 43, 5047.

32. Bauman V T, Shults E E, Shakirov M M, Tolstikov G A. Russ. J. Org. Chem. 2012, 48, 1473.

33. Woodward R B, J. Am. Chem. Soc. 1940, 62, 1625.

34. Slaunwhite Jr W R, Neely L. J. Org. Chem. 1962, 27, 1749.

35. Schwenk E, Castle C G, Joachim E. J. Org. Chem. 1963, 28, 136.

36. Leese M P, Hejaz H A, Mahon M F, Newman S P, Purohit A, Reed M J, Potter B V. J. Med. Chem. 2005, 48, 5243.

37. Chen A Y, Lee A J, Jiang X-R, Zhu B T. J. Med. Chem. 2007, 50, 5372.

38. Numazawa M, Ogura Y, Kimura K, Nagaoka M. J. Chem. Res. Synopses 1985, 11, 348.

39. Mukawa F. Tetrahedron Lett. 1959, 14, 17.

40. Mills J S, Barrera J, Olivares E, Garcia H, J. Am. Chem. Soc. 1960, 82, 5882.

41. Transition Metals for Organic Synthesis, ed.M. Beller and C. Bolm, Wiley-VCH, Weinheim, 2nd edn, 2004.]

42. Sonogashira K, Tohda Y, Hagihara N. Tetrahedron Lett. 1975, 4467.

43. Chinchilla R, Nájera C. Chem. Soc. Rev, 2011, 40, 5084.

44. Fauvarque F, Pflueger F, Troupel M. J. Organomet. Chem. 1981, 208, 419.

45. Miyaura N, Suzuki A. Chem Rev 1995, 95, 2457.

46. Stanforth S P. Tetrahedron 1998, 54, 263.

47. Kotha S, Lahiri K, Kashinath D. Tetrahedron 2002, 58, 9633.

48. Miyaura N. Top. Curr. Chem. 2002, 219, 11.

49. Bellina F, Carpita A, Rossi R. Synthesis 2004, 15, 2419.

50. Stille, J K, Lau, K S Y. Acc. Chem. Res. 1977, 10, 434.

51. Casado A L, Espiet P.. J. Am. Chem. Soc. 1998, 120, 8978.

52. Cotter W D, Barbour L, McNamara K L, et al. J. Am. Chem. Soc. 1998, 120, 11016.

53. van Leeuwen P W N M, Kamer P C J, Reek J N S, et al. Chem. Rev. 2000, 100, 2741.

54. Ferber B, Top S, Jaouen G J. Organomet. Chem. 2004, 689, 4872.

55. Ramesh C, Bryant, B, Nayak, T, et al. J. Am. Chem. Soc. 2006, 128, 14476.

56. Manosroi J, Rueanto K, Boonpisuttinant K, et al. J. Med. Chem. 2010, 53, 3937.

57. Möller G, Deluca D, Gege C, Rosinus A, Kowalik D, Peters O, Droescher P, Elger W, Adamski J, Hillisch A. Bioorg. Med. Chem. Lett. 2009, 19, 6740.

58. Doucet H, Hierso J-C. Angew. Chem. Int. Ed. 2007, 46, 834.

59. Mehta VP, Van der Eycken EV. Chem. Soc. Rev. 2011, 40, 4925.

60. Kabalka G W, Wang L, Namboodiri V, Pagni R M, Tetrahedron Lett. 2000, 41, 5151.

61. Erdélyi M, Gogoll A. J. Org. Chem. 2001, 66, 4165. 
62. Tron G C, Pirali T, Sorba G, Pagliai F, Busacca S, Genazzani A A. J. Med. Chem. 2006, 49, 3033.

63. Brown T, Holt H, Jr, Lee M. Top. Heterocycl. Chem. 2006, $2,1$.

64. https,//www.clinicaltrials.gov/ct2/show/NCT00507429 (hozzáférés dátuma, 2018.04.12.)

65. Gupta A, Kumar S B, Negi A S. J. Steroid Biochem. Mol. Biol. 2013, 137, 332.

66. Hauser F M, Ganguly D. J. Org. Chem. 2000, 65, 1842.

67. You Z-W, Jiang Z-X, Wang B-L, Qing F-L. J. Org. Chem. 2006, 71, 7261.

68. Sajiki H, Mori S, Ohkubo T, Ikawa T, Kume A, Maegawa T, Monguchi Y. Chem. Eur. J. 2008, 14, 5109 .

69. Hauwert P, Maestri G, Sprengers J W, Catellani M, Elsevier C J. Angew. Chem. Int. Ed. 2008, 47, 3223.

70. Brieger G, Nestrick T J. Chem. Rev. 1974, 74,567.

71. Johnstone R A W, Wilby A H. Chem. Rev. 1985, 85, 129.

72. Noyori R, Hashiguchi S. Acc. Chem. Res. 1997, 30, 97.

73. Gladiali S, Alberico E. Chem. Soc. Rev. 2006, 35, 226.

74. Samec J S M, Backvall J-E, Andersson P G, Brandt P. Chem. Soc. Rev. 2006, 35, 237.

75. Tani K, Ono N, Okamoto S, Sato F. J. Chem. Soc, Chem. Commun. 1993, 386.

76. Wei L-L, Wei L-M, Pan W-B, Leoua S-P, Wua M J. Tetrahedron Lett. 2003, 44, 1979.

77. Alonso F, Osante I, Yus M. Adv. Synth. Catal. 2006, 348, 305.

78. Sajiki H, Mori S, Ohkubo T, Ikawa T, Kume A, Maegawa T, Monguchi Y. Chem. Eur. J. 2008, 14, 5109.

79. Hauwert P, Maestri G, Sprengers J W, Catellani M, Elsevier C J. Angew. Chem, Int. Ed. 2008, 47, 3223.

80. Li J, Hua R, Liu, T. J. Org. Chem. 2010, 75, 2966.

81. Bhardwaj A, Sethi G, Vadhan-Raj S, Bueso-Ramos C, Takada Y, Gaur U, Nair AS, Shishodia S, Aggarwal BB. Blood 2007, 109, 2293.

82. Trapp V, Paramakhtiar B, Papazian V, Willmott L, Fruehauf J P. Angiogenesis 2010, $13,305$.

83. Hu Y, Rahlfs S, Mersch-Sundermann V, Becker K. J. Biol. Chem. 2007, 388, 207.

84. Griggs J, Metcalfe J C, Hesketh R. Lancet Oncology 2001, 2, 82.

85. Elliott P J, Walpole S, Morelli L, Lambert P D, Lunsmann W, Westphal C H, Lavu S, Drugs Fut. 2009, 34, 291.

86. Park J W, Choi Y J, Suh II S, Baek W K, Suh M H, Jin I N, Min D S, Woo J H, Chang J S, Passaniti A, Lee Y H, Kwon T K, Carcinogenesis 2001, 22, 1633.

87. Lucie F. Biological effects of resveratrol. Life Sci. 2000, 66, 663.

88. Dong Z G. Mutat. Res.-Fundam. Mol. Mech. Mutagen. 2003, 523, 145.

89. Gangjee A, Devraj R, McGuire J J, Kisliuk R L. J. Med Chem. 1995, 38, 7248.

90. Flynn B L, Hamel E, Jung M K. J. Med. Chem. 2002, 45, 2670.

91. Sundberg R J. Comprehensive Heterocyclic Chemistry II, ed. Katritzky, A. R, Rees, C. W, Scriven, E. F. V, Pergamon Press, Oxford, 1996, 2, 119.

92. Kotschy A, Timári G. Heterocycles from Transition Metal Catalysis, Springer, 2005

93. Villemin D, Goussu D. Heterocycles 1989, 29, 1255. 
94. Hiroya K, Suzuki N, Yasuhara A, Egawa Y, Kasano A, Sakamoto T. J. Chem. Soc. Perkin Trans., 2000, 1, 4339.

95. Guram A S, Rennels R A, Buchwald S L. Angew. Chem. Int. Ed. 1995, 34, 1348.

96. Louie J, Hartwig J F. Tetrahedron Lett. 1995, 36, 3609.

97. Ruiz-Castillo P, Blackmond D G, Buchwald S L. J. Am. Chem. Soc, 2015, 137, 3085.

98. Sunesson Y, Limé E, Lill S O N, Meadows R E, Norrby P-A. J. Org. Chem. 2014, 79, 11961.

99. Tundel R E, Anderson K W, Buchwald S L. J. Org. Chem. 2006, 71, 430.

100. Driver M S, Hartwig J F. J. Am. Chem. Soc. 1997, 119, 8232.

101. Hauwert P, Maestri G, Sprengers J W, Catellani M, Elsevier C J. Angew. Chem. Int. Ed. 2008, 47, 6338.

102. Kolb H C, Finn M G, Sharpless K B. Angew. Chem. Int. Ed. 2004, 43, 1871.

103. Lan X-B, Li Y, Li Y-F, Shen D-S, Ke Z, Liu F-S. J. Org. Chem. 2017, 82, 2914.

104. Wang T, Xu K, Liu L, Xie H, Li Y, Zhao W-X. Transition Met. Chem. 2016, 41, 525.

105. Wolfe J P, Buchwald S L, J. Org. Chem 2000, 65, 1144.

106. Pajtás Dávid, Doktori Disszertáció, 2015.

107. Singh C, Rathood J, Jha V, Panossian A, Kumar P, Leroux R F. Eur. J. Org. Chem 2015, 29, 6515.

108. Hartwig J F., Inorg. Chem. 2007, 46, 1936.

109. Samblanet D C, Schmidt J A R, J. Organomet. Chem. 2012, 720, 7.

110. Topchiy M A, Dzhevakov P B, Rubina M S, Morozov O S, Asachenko A F, Nechaev M S. Eur. J. Org. Chem. 2016, 1908.

111. Hill L L, Crowell J L, Tutwiler S L, Massie N L, Hines C C, Griffin S T, Rogers R D, Shaughnessy K H, Grasa G A, Johansson Seechurn C C, Li H, Colacot T J, Chou J, Woltermann C J. J. Org. Chem. 2010, 75, 6477.

112. Ernst J B, Schwermann C, Yokota G, Tada M, Muratsugu S, Doltsinis N L, Glorius F. J. Am. Chem. Soc. 2017, 139, 9144.

113. Ibrahim H, Bala M D. New J. Chem. 2016, 40, 6986.

114. Gajare A S, Toyota K, Yoshifuji M, Ozawa F. J. Org. Chem. 2004, 69, 6504.

115. Heravi M M, Kheilkordi Z, Zadsirjan V, Heydari M, Malmir M. J. Organomet. Chem. 2018, 861, 17.

116. Radu I I, Poirier D, Provencher L. Tetrahedron Lett. 2002, 43, 7617.

117. Schön U, Messinger J, Buchholz M, Reineceker U, Thole H. Tetrahedron Lett. 2005, $46,7111$.

118. Chen J, Wu J, Tu T. ACS Sustain. Chem. Eng. 2017, 5, 11744.

119. Lavoie C M, MacQueen R M, Rotta-Loria N L, Sawatzky R S, Borzenko A, Chisholm A J, Hargreaves B K V, McDonald R, Ferguson M J, Stradiotto M, Nature Commun. 201611073.

120. A. Treibs és F. H. Kreuzer. Liebigs Ann. Chem. 1969 721, 116.

121. Thermo Fisher - The Molecular Probes Handbook

122. Loudet A, Burgess K. Chem. Rev. 2007, 107, 4891.

123. Ulrich G, Ziessel R, Harriman A. Angew. Chem. Int. Ed, 2007, 47, 1184. 
124. Flores-Rizo J O, Esnal I, Osorio-Martínez C A, Goómez-Durán C F A, Bañuelos J, Arbeloa I L, Pannell K H, Metta-Magaña A J, Peña-Cabrera E. J. Org. Chem. 2013, 78, 5867.

125. Wagner R W, Lindsey J S. Pure Appl. Chem. 1996, 68, 1373.

126. Lee C-H, Lindsey J S. Tetrahedron 1994, 50, 11427.

127. French A N, Wilson S R, Welch M J, Katzenellenbogen J A. Steroids. 1993, 58, 157.

128. Okamoto M, Kobayashi S, Ikeuchia H, Yamada S, Yamanouchi K, Nagasawa K, Maekawa S, Kato T, Shimizu I. Steroids 2012, 77, 845.

129. Osati S, Ali H, Marques F, Paquette M, Beaudoin S, Guerin B, Leyton J V, van Lier J E. Bioorg. Med. Chem. Lett. 2017, 27, 443.

130. Osati S, Ali H, Guerina B, van Lier J E. Steroids 2017, 123, 27.

131. Osati S, Ali H, van Lier J E. 5th Georgian Bay Int. Conf. Bioinorg. Chem. 2015, book of abstracts

132. Hong Y, Chen S. Mol. Cell. Endocrinol. 2011, 340, 120.

133. Penning T M. J. Steroid Biochem. Mol. Biol. 2011, 125, 46.

134. Rizner T L. Front. Pharmacol. 2016, 7: 30.

135. Woo L W L, Leblond B, Purohit A, Potter B V L. Bioorg. Med. Chem. 2012, 20, 2506.

136. de Ziegler D, Mattenberger C, Luyet C, Romoscanu I, Irion N F, Bianchi-Demicheli F. J. Steroid Biochem. Mol. Biol. 2005, 95, 121.

137. Harper-Wynne C, Dowsett M. J. Steroid Biochem. Mol. Biol. 2001, 76, 179.

138. Gunnarsson C, Olsson B M, Stål O. Cancer Res. 2001, 61, 8448.

139. Poirier D. Anticancer Agents Med. Chem. 2009, 9, 642.

140. Brozic P, Lanišnik Rizner, T, Gobec, S. Curr. Med. Chem. 2008, 15, 137.

141. Oster A, Klein T, Werth R, Kruchten P, Bey E, Negri M, Marchais-Oberwinkler S, Frotscher M, Hartmann R W. Bioorg. Med. Chem. 2010, 18, 3494.

142. Messinger J, Hirvelä L, Husen B, Kangas L, Koskimies P, Pentikäinen O, Saarenketo P, Thole H. Mol. Cell. Endocrinol. 2006, 248, 192.

143. Breton R, Housset D, Mazza C, Fontecilla-Camps J C. Structure 1996, 4, 905.

144. Zhu, B. T, Han, G, Shim J, Wen, Y, Jiang, X. Endocrinology 2006, 147, 4132.

145. Chin C-C, Asmar P, Warren J C. J. Biol. Chem. 1980, 255, 3660.

146. Enginar H, Unak P, Lambrecht F Y, Biber Muftuler F Z, Medine E I. in vivo 2008, 22, 93.

147. Zhou Y, Chen P, Lv X, Niu J, Wang Y, Lei M, Hu L. Tetrahedron Lett. 2017, 58, 2232.

148. Fuentes-Aguilar A, Romero-Hernández L L, Arenas-González A, Merino-Montiel P, Montiel-Smith S, Meza-Reyes S, Vega-Báez J L, Plata GB, Padrón J M, López Ó, Fernández-Bolaños J G. Org. Biomol. Chem. 2017, 15, 5041.

149. Heinz Forster US Patent 20070099876 A1 2003

150. Selcer K W, Li P-K. J. Steroid Biochem. Mol. Biol. 1995, 52, 281.

151. Messinger J, Schoen U, Husen B, A2. 20080327, 2008.

152. Mernyák E, Schönecker B, Lange C, Kötteritzsch M, Görls H, Wölfling J, Schneider G, Steroids 2003, 68, 289.

153. Pravst I, Zupan M, Stavber S. Tetrahedron Lett. 2006, 47, 4707.

154. Vera W J, Banerjee A K. ARKIVOC 2009, xi, 228. 
155. Marie-Paule J, et al Bulletin de la Societe Chimique de France 1994, 131, 284.

156. Glaser C. Annalen der Chemie und Pharmacie. 1870, 154, 137.

157. Zhang W, Go M L. Eur. J. Med. Chem. 2007, 42, 841.

158. David L, Jagt V, Lorraine M D, Royer E R, Heidrich J E, Sillerud L O. U.S. Pat. Appl. Publ. US 20130178536 A1 20130711, 2013

159. Li Z-J, Cai L, Mei R-F, Dong J-W, Li S-Q, Yang X-Q, Zhou H, Yin T-P, Ding Z-T. Tetrahedron Lett. 2015, 56, 7197.

160. Deshpande, Pandurang Balwant, Palanisamy, Senthil Kumar Udayampalayam, Andrew, Gnanaprakasam U.S. Pat. Appl. Publ. (2004), US6844471B2

161. Jurásek M, Rimpelová S, Pavlícková V, Ruml T, Lapcík O, Drasar P B. Steroids 2015 97, 62.

162. Jurášek M, Rimpelová S, Kmoníčková E, Drašar P, Ruml T. J. Med. Chem. 2014, 57, 7947.

163. Malachowska-Ugarte M, Sperduto C, Ermolovich Y V, Sauchuk A L, Jurašek M, Litvinovskaya R P, Straltsova D, Smolich I, Zhabinskii V N, Drašar P, Demidchik V, Khripach V A. Steroids 2015, 102, 53.

164. Yalagala R S, Mazinani S A, Maddalena L A, Stuart J A, Yan F, Yan H. Carbohydrate Research 2016, 424, 15.

165. Mernyák E, Kozma E, Hetényi A, Mark L, Schneider G, Wölfling J. Steroids 2009, 74, 520.

166. Smith L L, Teller D M. US3177206, 1965

167. Černý I, Pouzar V, Lapcik O, Hampl R. Collect Czech. Chem. Commun. 1997, 62, 1931. 


\section{Köszönetnyilvánítás}

Mindenekelőtt köszönettel tartozom témavezetőmnek Dr. Mernyák Erzsébet egyetemi adjunktusnak, aki a mesterképzés óta segíti pályafutásom és hihetetlen lelkesedése a szerves kémia iránt engem is magával ragadott. Továbbá köszönöm Neki disszertációm alapos áttanulmányozását és értékes tanácsait a kutatómunkához és a stílusbeli finomításokhoz.

Köszönettel tartozom Dr. Wölfling János tanszékvezető egyetemi tanárnak, kutatásom feltételeinek biztosításáért, tanácsaiért és támogatásáért.

Hálával tartozom Dr. Schneider Gyulának, professzor emeritusnak a labormunka sokéves tapasztalatainak megosztásáért és az előadások érdeklődő figyelemmel kíséréséért és bölcs javaslataiért.

Köszönettel tartozom együttműködő partnereinknek Dr. Szécsi Mihálynak és Herman Bianka Edinának az enzimgátlási vizsgálatokért és Dr. Özvegy-Laczka Csillának és Rigó Rékának a fluoreszcens spektrumok felvételéért.

Köszönöm a tömegspektrumok felvételét Dr. Varga Mónikának, Kele Zoltánnak, Fekete Lillának és Kecskeméti Gábornak.

Hálával tartozom Kutatócsoportunk minden tagjának, különösképpen korábbi $\mathrm{PhD}$ hallgatónak, immár Dr. Zóka Johannának, aki egyszerre kolléga, mentor és jóbarát. Köszönettel tartozom Jójárt Rebekának, aki BSc éveiben az első hallgatóm volt és jelenleg kutatócsoportunk PhD hallgatója. Továbbá köszönöm a munkáját azoknak a BSc és MSc-s hallgatóknak, akikkel az évek során együtt dolgoztam: Herman Kevin Stefannak és Szemerédi Dávid Krisztiánnak, valamint Konc Csillának és Orosz Anna Boglárkának.

Külön köszönöm Családomnak és Barátaimnak, akik mindvégig mellettem álltak és támogattak.

Köszönöm az OTKA SNN 124329 és OTKA K113150 valamint a GINOP-2.3.2-15-201600038, számú pályázatának és a Richter Gedeon Centenáriumi Alapítványának anyagi támogatását. 
9. Mellékletek

I. A vegyületek fizikai adatai

\begin{tabular}{|c|c|c|c|c|c|}
\hline Szám & Vegyület képlete & $\begin{array}{c}\text { Összegképlet } \\
\text { Molekulatömeg }\end{array}$ & $\begin{array}{c}\text { Hozam } \\
(\%)\end{array}$ & Op. $\left({ }^{\circ} \mathrm{C}\right)$ & $\mathbf{R}_{\mathbf{f}}$ \\
\hline 113 & & $\begin{array}{c}\mathrm{C}_{18} \mathrm{H}_{21} \mathrm{IO}_{2} \\
396,06\end{array}$ & 43 & $205-208$ & $0,36^{\mathrm{a}}$ \\
\hline 114 & & $\begin{array}{c}\mathrm{C}_{18} \mathrm{H}_{21} \mathrm{IO}_{2} \\
396,06\end{array}$ & 45 & $209-211$ & $0,52^{\mathrm{a}}$ \\
\hline 115 & & $\begin{array}{c}\mathrm{C}_{18} \mathrm{H}_{20} \mathrm{I}_{2} \mathrm{O}_{2} \\
521,96\end{array}$ & 47 & 198-201 & $0,66^{\mathrm{a}}$ \\
\hline 116 & & $\begin{array}{c}\mathrm{C}_{19} \mathrm{H}_{23} \mathrm{IO}_{2} \\
410,07\end{array}$ & 47 & $184-185$ & $0,53^{\mathrm{a}}$ \\
\hline 117 & & $\begin{array}{c}\mathrm{C}_{19} \mathrm{H}_{23} \mathrm{IO}_{2} \\
410,07\end{array}$ & 41 & $151-152$ & $0,68^{\mathrm{a}}$ \\
\hline 118 & & $\begin{array}{c}\mathrm{C}_{18} \mathrm{H}_{23} \mathrm{IO} \\
382,08\end{array}$ & 48 & $60-63$ & $0,47^{\mathrm{d}}$ \\
\hline 119 & & $\begin{array}{c}\mathrm{C}_{18} \mathrm{H}_{23} \mathrm{IO} \\
382,08\end{array}$ & 24 & $91-92$ & $0,58^{\mathrm{d}}$ \\
\hline 120 & & $\begin{array}{c}\mathrm{C}_{18} \mathrm{H}_{22} \mathrm{I}_{2} \mathrm{O} \\
507,98\end{array}$ & 24 & $145-148$ & $0,79^{\mathrm{d}}$ \\
\hline 121 & & $\begin{array}{c}\mathrm{C}_{18} \mathrm{H}_{21} \mathrm{BrO}_{2} \\
348,07\end{array}$ & 24 & $222-225$ & $0,65^{\mathrm{a}}$ \\
\hline
\end{tabular}




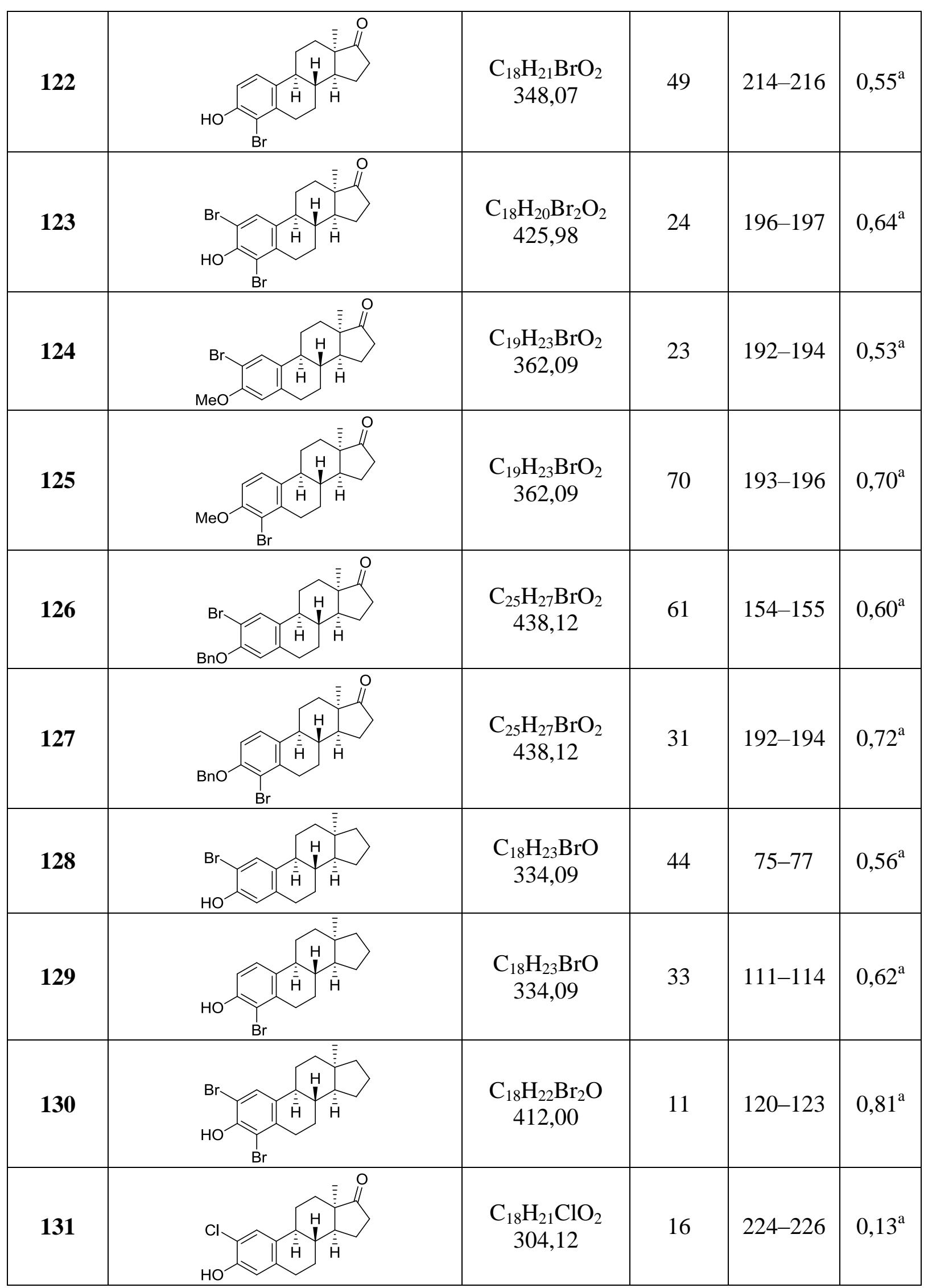




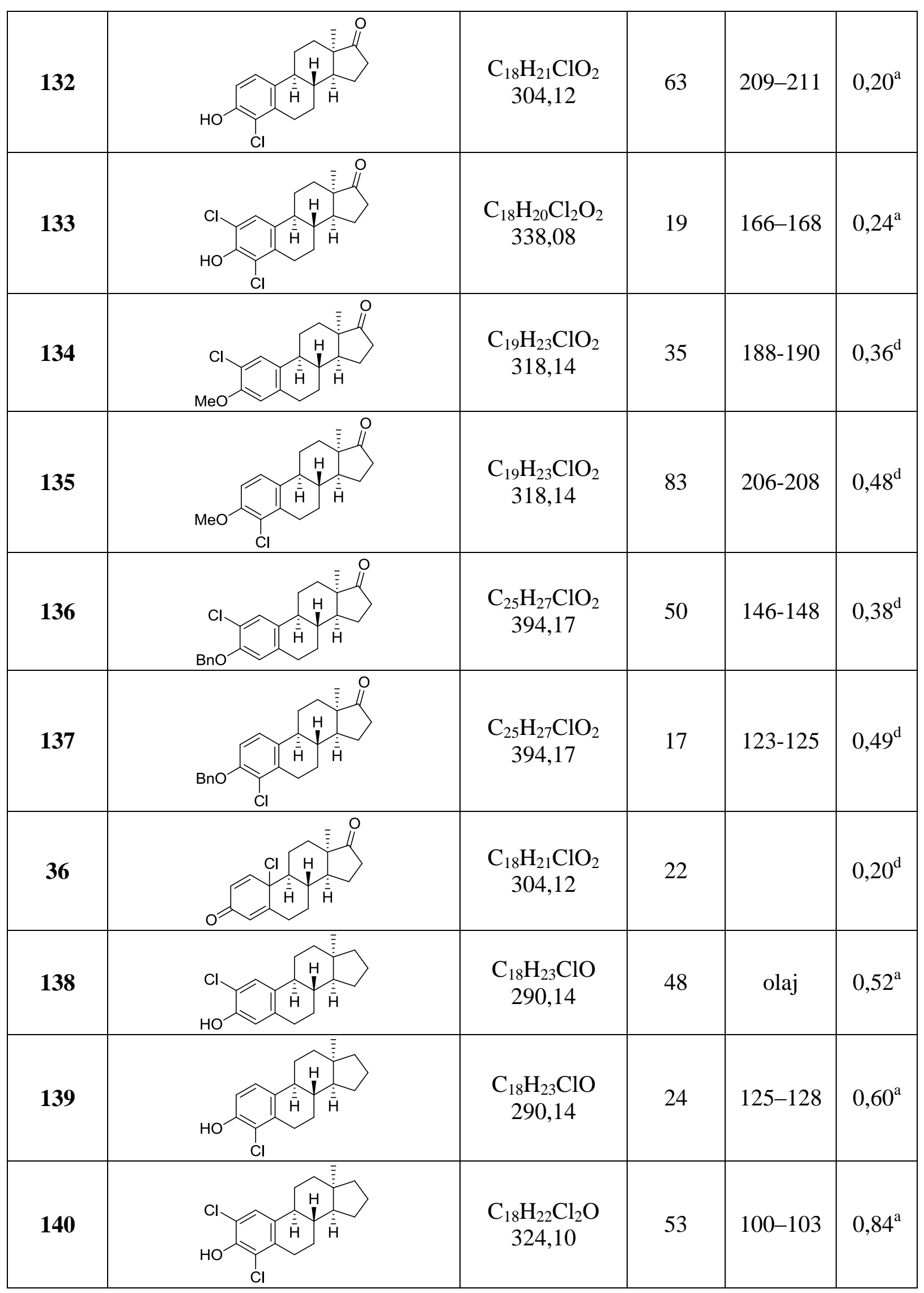




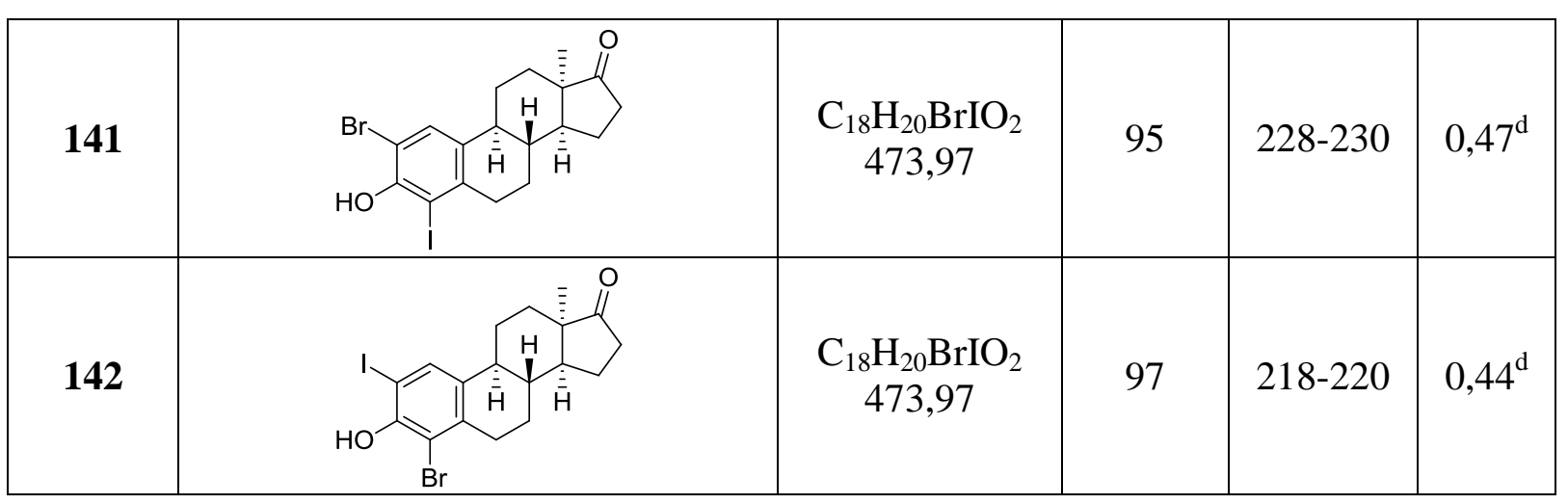




\section{A vegyületek NMR adatai}

113: ${ }^{1} \mathrm{H}$ NMR $\left(\mathrm{CDCl}_{3}\right): \delta$ ppm: $1,05\left(\mathrm{~s}, 3 \mathrm{H}, 18-\mathrm{H}_{3}\right) ; 2,77$ (m, 2H, 6- $\left.\mathrm{H}_{2}\right) ; 5,09(\mathrm{~s}, 1 \mathrm{H}, \mathrm{OH})$; 6,70 (s, 1H, 4-H); 7,50 (s, 1H, 1-H); ${ }^{13} \mathrm{C}$ NMR (DMSO-d 6 ) $\delta$ ppm: 20,5; 24,6; 27,6; 28,1; 29,$3 ; 31,6 ; 32,9 ; 40,4 ; 40,6 ; 48,5 ; 49,5(\mathrm{C}-13) ; 104,9 ; 114,6 ; 132,7 ; 135,9 ; 138,3 ; 154,2(\mathrm{C}-3)$; $220,6(\mathrm{C}-17)$.

114: ${ }^{1} \mathrm{H}$ NMR $\left(\mathrm{CDCl}_{3}\right)$ : $\delta$ ppm: 1,06 (s, 3H, 18- $\left.\mathrm{H}_{3}\right) ; 2,64$ és $2,86\left(2 \times \mathrm{m}, 2\right.$ x 1H, 6- $\left.\mathrm{H}_{2}\right) ; 5,39$ $(\mathrm{s}, 1 \mathrm{H}, \mathrm{OH}) ; 6,82(\mathrm{~d}, 1 \mathrm{H}, J=8,5 \mathrm{~Hz}, 2-\mathrm{H}) ; 7,18(\mathrm{~d}, 1 \mathrm{H}, J=8,5 \mathrm{~Hz}, 1-\mathrm{H}) ;{ }^{13} \mathrm{C}$ NMR (DMSO$\left.\mathrm{d}_{6}\right) \delta$ ppm: 21,0; 25,0; 28,5; 29,0; 32,0; 33,4; 37,5; 40,8; 41,7; 49,0(C-13); 50,0; 112,1; 127,4; 133,$7 ; 139,5 ; 141,3 ; 152,7(\mathrm{C}-3) ; 211,5(\mathrm{C}-17)$.

115: ${ }^{1} \mathrm{H}$ NMR (DMSO-d 6 ): $\delta$ ppm: 0,96 (s, 3H, 18- $\left.\mathrm{H}_{3}\right) ; 2,53$ és 2,68 (2xm, 2x1H, 6- $\left.\mathrm{H}_{2}\right) ; 7,60$ (s, 1H, 1-H); 9,21 (s, 1H, OH); ${ }^{13} \mathrm{C}$ NMR (DMSO-d $\left.)_{6}\right): \delta$ ppm: 20,4, 24,3 (C-18); 28,2, 28,3, 31,4, 32,8, 37,4, 39,5, 40,6, 48,1, 49,2, 83,5 (C-2); 95,9 (C-4); 135,8 (C-10); 136,0 (C-1); 140,6 (C-5); 152,9 (C-3); 220,6 (C-17).

116: ${ }^{1} \mathrm{H}$ NMR $\left(\mathrm{CDCl}_{3}\right)$ : $\delta$ ppm: $1,05\left(\mathrm{~s}, 3 \mathrm{H}, 18-\mathrm{H}_{3}\right) ; 2,80\left(\mathrm{~m}, 2 \mathrm{H}, 6-\mathrm{H}_{2}\right) ; 3,82\left(\mathrm{~s}, 3 \mathrm{H}, \mathrm{OCH}_{3}\right)$; 6,51 (s, 1H, 4-H); 7,63 (s, 1H, 1-H); ${ }^{13} \mathrm{C} \mathrm{NMR}\left(\mathrm{CDCl}_{3}\right): \delta \mathrm{ppm}: 21,0,25,1(\mathrm{C}-18) ; 28,1,28,3$, 30,3, 32,0, 33,4, 41,2, 41,3, 49,2, 50,1, 56,3 $\left(\mathrm{OCH}_{3}\right)$; 82,8 (C-2); 111,1 (C-4); 134,3 (C-10); 137,0 (C-1); 138,4 (C-5); 156,3 (C-3); 221,3 (C-17).

117: ${ }^{1} \mathrm{H}$ NMR $\left(\mathrm{CDCl}_{3}\right): \delta$ ppm: 1,06 (s, 3H, 18- $\left.\mathrm{H}_{3}\right) ; 2,67$ és 2,94 (2xm, 2x1H, 6- $\left.\mathrm{H}_{2}\right) ; 3,86$ (s, $\left.3 \mathrm{H}, \mathrm{OCH}_{3}\right) ; 6,65(\mathrm{~d}, 1 \mathrm{H}, J=8,6 \mathrm{~Hz}, 2-\mathrm{H}) ; 7,24(\mathrm{~d}, 1 \mathrm{H}, J=8,6 \mathrm{~Hz}, 1-\mathrm{H}) ;{ }^{13} \mathrm{C} \mathrm{NMR}\left(\mathrm{CDCl}_{3}\right)$ : $\delta$ ppm: 21,1, 25,0 (C-18); 28,5, 29,2, 32,0, 33,4, 37,6, 40,9, 41,8, 49,1, 50,0, 56,5 $\left(\mathrm{OCH}_{3}\right)$; 94,6 (C-4); 108,4 (C-2); 126,7 (C-1); 134,2 (C-10); 140,9 (C-5); 156,1 (C-3); 221,4 (C-17);

118: ${ }^{1} \mathrm{H}$ NMR $\left(\mathrm{CDCl}_{3}\right) \delta$ ppm: 0,96(s, 3H, 18- $\left.\mathrm{H}_{3}\right) ; 2,74\left(\mathrm{~m}, 2 \mathrm{H}, 6-\mathrm{H}_{2}\right) ; 5,08(\mathrm{~s}, 1 \mathrm{H}, \mathrm{OH})$; 6,70(s, 1H, 4-H); 7,55(s, 1H, 1-H); ${ }^{13} \mathrm{C} \mathrm{NMR}\left(\mathrm{CDCl}_{3}\right) \delta$ ppm: 20,9; 27,0; 27,8; 28,1; 29,9(C18); 30,1; 33,5; 35,6; 40,9; 41,8(C-13);42,0; 51,6; 82,5(C-2); 114,7(C-4); 135,6(C-1); 135,7(C-10); 139,8(C-5); 152,3(C-3); $\mathrm{MS}^{\mathrm{I}} \mathrm{m} / \mathrm{z}(\%): 507\left(100,[\mathrm{M}-\mathrm{H}]^{-}\right)$.

119: ${ }^{1} \mathrm{H}$ NMR $\left(\mathrm{CDCl}_{3}\right) \delta$ ppm: 0,96(s, 3H, 18- $\left.\mathrm{H}_{3}\right) ; 2,62$ és $2,82\left(2 \mathrm{xm}, 2 \mathrm{x} 1 \mathrm{H}, 6-\mathrm{H}_{2}\right) ; 5,35(\mathrm{~s}$, $1 \mathrm{H}, \mathrm{OH}) ; 6,84(\mathrm{~d}, 1 \mathrm{H}, J=8,3 \mathrm{~Hz}, 2-\mathrm{H}) ; 7,23(\mathrm{~d}, 1 \mathrm{H}, J=8,3 \mathrm{~Hz}, 1-\mathrm{H}) ;{ }^{13} \mathrm{C} \mathrm{NMR}\left(\mathrm{CDCl}_{3}\right) \delta$ ppm: 20,9; 27,3; 27,8; 29,1; 29,9(C-18); 33,5; 35,7; 37,8; 40,6; 41,8(C-13); 42,6; 51,5; 95,0(C-4); 111,9(C-2); 127,4(C-1); 134,9(C-10); 139,9(C-5); 152,5(C-3); $\mathrm{MS}^{\mathrm{I}} \mathrm{m} / \mathrm{z}(\%): 381$ $\left(100,[\mathrm{M}-\mathrm{H}]^{-}\right)$. 
120: ${ }^{1} \mathrm{H}$ NMR (DMSO-d $\left.{ }_{6}\right) \delta$ ppm: $0,91\left(\mathrm{~s}, 3 \mathrm{H}, 18-\mathrm{H}_{3}\right) ; 2,46$ és 2,69 (2xm, $\left.2 \mathrm{x} 1 \mathrm{H}, 6-\mathrm{H}_{2}\right)$; 7,63(s, 1H, 1-H); 9,21(s, 1H, OH); ${ }^{13} \mathrm{C} \mathrm{NMR}\left(\mathrm{CDCl}_{3}\right) \delta \mathrm{ppm}: 20,9 ; 27,2 ; 27,8 ; 28,9 ; 29,8(\mathrm{C}-$ 18); 33,4; 35,5; 37,8; 40,2; 41,7(C-13); 42,3; 51,4; 78,3(C-2); 91,8(C-4); 136,4(C-1); 137,0(C-10); 141,3(C-5); 151,0(C-3); $\mathrm{MS}^{\mathrm{I}} \mathrm{m} / \mathrm{z}(\%): 381\left(100,[\mathrm{M}-\mathrm{H}]^{-}\right)$.

121: ${ }^{1} \mathrm{H}$ NMR (DMSO-d $\left.{ }_{6}\right): \delta$ ppm: 0,96 (s, 3H, 18- $\left.\mathrm{H}_{3}\right) ; 2,66\left(\mathrm{~m}, 2 \mathrm{H}, 6-\mathrm{H}_{2}\right) ; 6,61(\mathrm{~s}, 1 \mathrm{H}, 4-\mathrm{H})$; 7,27 (s, 1H, 1-H); 9,81 (s, 1H, OH); ${ }^{13} \mathrm{C}$ NMR (DMSO-d 6 ): $\delta$ ppm: 20,3, 24,4 (C-18); 27,5, 27,9, 29,1, 31,4, 32,8, 39,8, 40,4, 48,3, 49,3, 106,5 (C-2); 115,8 (C-4); 129,8 (C-1); 132,0 (C10); 137,2 (C-5); 151,4 (C-3); 220,4 (C-17);

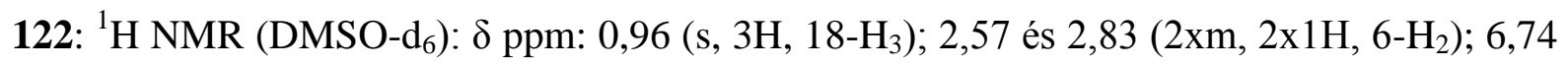
$(\mathrm{d}, 1 \mathrm{H}, J=8,5 \mathrm{~Hz}, 2-\mathrm{H}) ; 7,10(\mathrm{~d}, 1 \mathrm{H}, J=8,5 \mathrm{~Hz}, 1-\mathrm{H}) ; 9,83(\mathrm{~s}, 1 \mathrm{H}, \mathrm{OH}) ;{ }^{13} \mathrm{C}$ NMR (DMSO$\mathrm{d}_{6}$ ): $\delta$ ppm: 20,4, 24,4 (C-18); 27,7, 28,1, 31,2, 31,5, 32,8, 39,8, 40,9, 48,2, 49,2, 112,0 (C-4); 113,2 (C-2); 125,4 (C-1); 132,1 (C-10); 136,7 (C-5); 151,7 (C-3); 220,5 (C-17);

123: ${ }^{1} \mathrm{H}$ NMR (DMSO-d 6 ): $\delta$ ppm: 0,96 (s, 3H, 18- $\mathrm{H}_{3}$ ); 2,56 és 2,78 (2xm, 2x1H, 6- $\left.\mathrm{H}_{2}\right) ; 7,41$ (s, 1H, 1-H); 9,50 (s, 1H, OH); ${ }^{13} \mathrm{C}$ NMR (DMSO-d 6 ): $\delta$ ppm: 20,4, 24,3 (C-18); 27,5, 28,0, $31,2,31,3,32,8,39,5,40,7,48,1,49,2,108,7$ (C-2); 115,0 (C-4); 128,9 (C-1); 134,6 (C-10); 136,6 (C-5); 148,3 (C-3); 220,4 (C-17);

124: ${ }^{1} \mathrm{H}$ NMR $\left(\mathrm{CDCl}_{3}\right): \delta$ ppm: $1,05\left(\mathrm{~s}, 3 \mathrm{H}, 18-\mathrm{H}_{3}\right) ; 2,78\left(\mathrm{~m}, 2 \mathrm{H}, 6-\mathrm{H}_{2}\right) ; 3,83\left(\mathrm{~s}, 3 \mathrm{H}, \mathrm{OCH}_{3}\right)$; 6,56 (s, 1H, 4-H); 7,40 (s, 1H, 1-H); ${ }^{13} \mathrm{C} \mathrm{NMR}\left(\mathrm{CDCl}_{3}\right): \delta$ ppm: 20,9, 25,0 (C-18); 28,1, 28,2, 30,1, 31,9, 33,3, 41,2 (2C); 49,1, 50,0, 56,1 $\left(\mathrm{OCH}_{3}\right) ; 108,8$ (C-2); 112,1 (C-4); 130,7 (C-1); 133,5 (C-10); 137,2 (C-5); 153,6 (C-3); 221,2 (C-17);

125: ${ }^{1} \mathrm{H}$ NMR $\left(\mathrm{CDCl}_{3}\right): \delta$ ppm: $1,06\left(\mathrm{~s}, 3 \mathrm{H}, 18-\mathrm{H}_{3}\right) ; 2,69$ és $3,00\left(2 \mathrm{xm}, 2 \mathrm{x} 1 \mathrm{H}, 6-\mathrm{H}_{2}\right) ; 3,86(\mathrm{~s}$, $\left.3 \mathrm{H}, \mathrm{OCH}_{3}\right) ; 6,73(\mathrm{~d}, 1 \mathrm{H}, J=8,6 \mathrm{~Hz}, 2-\mathrm{H}) ; 7,21(\mathrm{~d}, 1 \mathrm{H}, J=8,6 \mathrm{~Hz}, 1-\mathrm{H}) ;{ }^{13} \mathrm{C} \mathrm{NMR}\left(\mathrm{CDCl}_{3}\right)$ : $\delta$ ppm: 21,1, 25,0 (C-18); 28,4 (2C); 31,6, 32,0, 33,4, 40,7, 41,7, 49,1, 50,0, 56,3 $\left(\mathrm{OCH}_{3}\right)$; 109,2 (C-2); 114,4 (C-4); 125,4 (C-1); 134,1 (C-10); 137,8 (C-5); 153,9 (C-3); 221,4 (C-17);

126: ${ }^{1} \mathrm{H}$ NMR $\left(\mathrm{CDCl}_{3}\right): \delta$ ppm: $1,05\left(\mathrm{~s}, 3 \mathrm{H}, 18-\mathrm{H}_{3}\right) ; 2,76\left(\mathrm{~m}, 2 \mathrm{H}, 6-\mathrm{H}_{2}\right) ; 5,09\left(\mathrm{~s}, 2 \mathrm{H}, \mathrm{OCH}_{2}\right)$; 6,64 (s, 1H, 4-H); 7,31 (t, 1H, $J=7,3 \mathrm{~Hz}, 4$ '-H); 7,37 (t, 2H, $J=7,3 \mathrm{~Hz}, 3$ '-H és 5'-H); 7,43

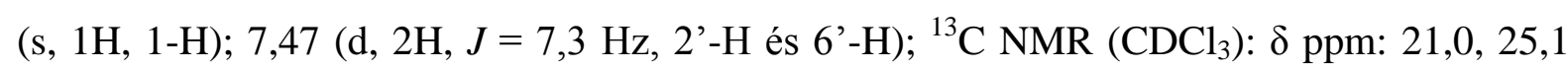
(C-18); 28,1, 28,2, 30,1, 32,0, 33,4, 41,2, 41,3, 49,2, 50,1, 70,8 $\left(\mathrm{OCH}_{2}\right) ; 109,7$ (C-2); 114,0 (C-4); 127,0 (2C: C-2', C-6'); 127,8 (C-4'); 128,5 (2C: C-3', C-5'); 130,8 (C-1); 133,9 (C10); 136,7 (C-1'); 137,1 (C-5); 152,8 (C-3); 221,2 (C-17); 
127: ${ }^{1} \mathrm{H}$ NMR $\left(\mathrm{CDCl}_{3}\right): \delta$ ppm: 1,06 (s, 3H, 18- $\left.\mathrm{H}_{3}\right) ; 2,69$ és 3,02 (2xm, 2x1H, 6- $\left.\mathrm{H}_{2}\right) ; 5,13(\mathrm{~s}$, $\left.2 \mathrm{H}, \mathrm{OCH}_{2}\right) ; 6,76(\mathrm{~d}, 1 \mathrm{H}, J=8,4 \mathrm{~Hz}, 2-\mathrm{H}) ; 7,17(\mathrm{~d}, 1 \mathrm{H}, J=8,4 \mathrm{~Hz}, 1-\mathrm{H}) ; 7,32(\mathrm{t}, 1 \mathrm{H}, J=7,3$ $\left.\mathrm{Hz}, 4^{\prime}-\mathrm{H}\right) ; 7,38$ (t, 2H, $J=7,3 \mathrm{~Hz}, 3$ '-H és 5'-H); 7,47 (d, 2H, $J=7,3 \mathrm{~Hz}, 2$ '-H és 6'-H); ${ }^{13} \mathrm{C}$ NMR $\left(\mathrm{CDCl}_{3}\right): \delta$ ppm: 21,0, 25,0 (C-18); 28,4, 28,5, 31,6, 32,0, 33,4, 40,6, 41,7, 49,1, 50,0, 70,9 $\left(\mathrm{OCH}_{2}\right) ; 111,1(\mathrm{C}-2) ; 115,3(\mathrm{C}-4) ; 125,3$ (C-1); 126,9 (2C: C-2', C-6'); 127,7 (C-4'); 128,5 (2C: C-3', C-5'); 134,4 (C-10); 136,8 (C-1'); 137,9 (C-5); 153,0 (C-3); 221,3 (C-17);

128: ${ }^{1} \mathrm{H}$ NMR (DMSO-d $\left.{ }_{6}\right) \delta$ ppm: 0,96(s, 3H, 18- $\left.\mathrm{H}_{3}\right) ; 2,63\left(\mathrm{~m}, 2 \mathrm{H}, 6-\mathrm{H}_{2}\right) ; 6,61(\mathrm{~s}, 1 \mathrm{H}, 4-\mathrm{H})$; 7,30(s, 1H, 1-H); 9,78(s, 1H, OH); ${ }^{13} \mathrm{C}$ NMR (DMSO-d 6 ) $\delta$ ppm: 20,3; 26,4; 27,2; 27,6; 29,3; 29,6(C-18); 33,0; 35,2; 40,4; 41,3(C-13); 41,4; 51,0; 106,5(C-2); 115,8(C-4); 129,7(C-1); 132,6(C-10); 137,1(C-5); 151,3(C-3). $\mathrm{MS}^{\mathrm{I}} \mathrm{m} / \mathrm{z}(\%): 333\left(100,[\mathrm{M}-\mathrm{H}]^{-}\right)$.

129: ${ }^{1} \mathrm{H}$ NMR (DMSO-d $\left.\mathrm{d}_{6}\right) \delta$ ppm: 0,93(s, 3H, 18- $\left.\mathrm{H}_{3}\right) ; 2,52$ és 2,80 (2xm, 2x1H, 6- $\left.\mathrm{H}_{2}\right)$; 6,75(d, $1 \mathrm{H}, J=8,2 \mathrm{~Hz}, 2-\mathrm{H}) ; 7,14(\mathrm{~d}, 1 \mathrm{H}, J=8,2 \mathrm{~Hz}, 1-\mathrm{H}) ; 9,81(\mathrm{~s}, 1 \mathrm{H}, \mathrm{OH}) ;{ }^{13} \mathrm{C}$ NMR (DMSOd ${ }_{6} \delta$ ppm: 20,4; 26,7; 27,2; 27,9; 29,6(C-18); 31,5; 32,9; 35,3; 39,9; 41,4(C-13); 42,0; 50,9; 112,1(C-4); 113,2(C-2); 125,5(C-1); 132,7(C-10); 136,7(C-5); 151,6(C-3). MS ${ }^{\mathrm{I}} \mathrm{m} / \mathrm{z}(\%): 333$ $\left(100,[\mathrm{M}-\mathrm{H}]^{-}\right)$.

130: ${ }^{1} \mathrm{H}$ NMR $\left(\mathrm{CDCl}_{3}\right) \delta$ ppm: 0,96(s, 3H, 18- $\left.\mathrm{H}_{3}\right) ; 2,58$ és $2,87\left(2 \mathrm{xm}, 2 \mathrm{x} 1 \mathrm{H}, 6-\mathrm{H}_{2}\right) ; 5,81(\mathrm{~s}$, $1 \mathrm{H}, \mathrm{OH}) ; 7,44(\mathrm{~s}, 1 \mathrm{H}, 1-\mathrm{H}) ;{ }^{13} \mathrm{C} \mathrm{NMR}\left(\mathrm{CDCl}_{3}\right) \delta \mathrm{ppm}: 20,9 ; 27,2 ; 27,8 ; 28,2 ; 29,9(\mathrm{C}-18)$; 31,$8 ; 33,4 ; 35,6 ; 40,2 ; 41,8(\mathrm{C}-13) ; 42,4 ; 51,5 ; 106,4(\mathrm{C}-2) ; 112,9(\mathrm{C}-4) ; 129,1(\mathrm{C}-1) ; 136,1$ és 137,2(C-5 és C-10); 146,9(C-3). MS ${ }^{\mathrm{II}} \mathrm{m} / z$ (\%): 390 (100); $413\left(45,[\mathrm{M}+\mathrm{H}]^{+}\right)$.

131: ${ }^{1} \mathrm{H}$ NMR (DMSO-d $\left.{ }_{6}\right) \delta$ ppm: 0,96(s, 3H, 18- $\left.\mathrm{H}_{3}\right) ; 2,67\left(\mathrm{~m}, 2 \mathrm{H}, 6-\mathrm{H}_{2}\right) ; 6,62(\mathrm{~s}, 1 \mathrm{H}, 4-\mathrm{H})$; 7,14(s, 1H, 1-H); 9,75(s, 1H, OH); ${ }^{13} \mathrm{C}$ NMR (DMSO-d 6 ) $\delta$ ppm: 20,4; 24,4(C-18); 27,5; 27,$9 ; 29,0 ; 31,5 ; 32,8 ; 40,4 ; 40,5 ; 49,3(\mathrm{C}-13) ; 116,1(\mathrm{C}-4) ; 116,9(\mathrm{C}-2) ; 126,8(\mathrm{C}-1) ; 131,5(\mathrm{C}-$ 10); 136,5(C-5); 150,4(C-3); 220,5(C-17). $\mathrm{MS}^{\mathrm{I}} \mathrm{m} / \mathrm{z}(\%): 303\left(100,[\mathrm{M}-\mathrm{H}]^{-}\right)$.

132: ${ }^{1} \mathrm{H}$ NMR (DMSO-d $\left.{ }_{6}\right) \delta$ ppm: 0,96(s, 3H, 18- $\left.\mathrm{H}_{3}\right) ; 2,58$ és 2,85(2xm, $\left.2 \mathrm{H}, 6-\mathrm{H}_{2}\right) ; 6,75(\mathrm{~d}$, $1 \mathrm{H}, J=8,5 \mathrm{~Hz} 4-\mathrm{H}) ; 7,06(\mathrm{~d}, 1 \mathrm{H}, J=8,5 \mathrm{~Hz}, 1-\mathrm{H}) ; 9,73(\mathrm{~s}, 1 \mathrm{H}, \mathrm{OH}) ;{ }^{13} \mathrm{C} \mathrm{NMR}\left(\mathrm{CDCl}_{3}\right) \delta$ ppm 21,0; 25,0(C-18); 27,9; 28,0; 28,4; 31,9; 33,4; 40,7; 41,6; 49,0; 50,0(C-13); 113,1(C-2); 119,9(C-4); 125,3(C-1); 133,3(C-10); 134,9(C-5); 149,2(C-3); 221,5(C-17). MS ${ }^{\mathrm{I}} \mathrm{m} / \mathrm{z}$ (\%): $303\left(100,[\mathrm{M}-\mathrm{H}]^{-}\right)$.

133: ${ }^{1} \mathrm{H}$ NMR (DMSO-d $\left.{ }_{6}\right) \delta$ ppm: 1,06(s, 3H, 18- $\left.\mathrm{H}_{3}\right) ; 2,63$ és 2,94(2xm, 2H, 6- $\left.\mathrm{H}_{2}\right) ; 5,74(\mathrm{~s}$, $1 \mathrm{H}, \mathrm{OH}) ; 7,19(\mathrm{~s}, 1 \mathrm{H}, 1-\mathrm{H}) ;{ }^{13} \mathrm{C} \mathrm{NMR}\left(\mathrm{CDCl}_{3}\right) \delta$ ppm 21,0; 25,0(C-18); 27,8; 28,2; 28,3; 
31,$8 ; 33,3 ; 40,5 ; 41,5 ; 48,9 ; 49,9(\mathrm{C}-13) ; 118,0$ és $120,8(\mathrm{C}-2$ és C-4); 125,3(C-1); 133,8(C10); 134,4(C-5); 145,5(C-3); 221,2(C-17). $\mathrm{MS}^{\mathrm{I}} \mathrm{m} / \mathrm{z}(\%): 337\left(100,[\mathrm{M}-\mathrm{H}]^{-}\right)$.

134: ${ }^{1} \mathrm{H}$ NMR $\left(\mathrm{CDCl}_{3}\right): \delta$ ppm: $1,05\left(\mathrm{~s}, 3 \mathrm{H}, 18-\mathrm{H}_{3}\right) ; 2,81\left(\mathrm{~m}, 2 \mathrm{H}, 6-\mathrm{H}_{2}\right) ; 3,84(\mathrm{~s}, 3 \mathrm{H}, 3-$ $\left.\mathrm{OCH}_{3}\right) ; 6,61(\mathrm{~s}, 1 \mathrm{H}, 4-\mathrm{H}) ; 7,24(\mathrm{~s}, 1 \mathrm{H}, 1-\mathrm{H})$.

135: $\delta$ ppm: $1,06\left(\mathrm{~s}, 3 \mathrm{H}, 18-\mathrm{H}_{3}\right) ; 2,67$ és $3,03\left(2 \mathrm{xm}, 2 \mathrm{x} 1 \mathrm{H}, 6-\mathrm{H}_{2}\right) ; 3,86\left(\mathrm{~s}, 3 \mathrm{H}, 3-\mathrm{OCH}_{3}\right)$; $6,76(\mathrm{~d}, 1 \mathrm{H}, J=8,6 \mathrm{~Hz}, 2-\mathrm{H}) ; 7,16(\mathrm{~d}, 1 \mathrm{H}, J=8,6 \mathrm{~Hz}, 1-\mathrm{H}) .{ }^{13} \mathrm{C} \mathrm{NMR}\left(\mathrm{CDCl}_{3}\right) \delta \mathrm{ppm} 21,1$; $25,0(\mathrm{C}-18) ; 28,1 ; 28,3 ; 28,4 ; 31,9 ; 33,5 ; 40,6 ; 41,6 ; 49,1 ; 50,0(\mathrm{C}-13) ; 56,1\left(3-\mathrm{OCH}_{3}\right) ; 109,2$; 122,$1 ; 124,5 ; 133,7 ; 136,2 ; 152,9(\mathrm{C}-3) ; 221,5(\mathrm{C}-17)$

136: ${ }^{1} \mathrm{H}$ NMR $\left(\mathrm{CDCl}_{3}\right): \delta$ ppm: $1,05\left(\mathrm{~s}, 3 \mathrm{H}, 18-\mathrm{H}_{3}\right) ; 2,76\left(\mathrm{~m}, 2 \mathrm{H}, 6-\mathrm{H}_{2}\right) ; 5,09\left(\mathrm{~s}, 2 \mathrm{H}, \mathrm{OCH}_{2}\right)$; 6,64(s, 1H, 4-H); 7,26 (s, 1H, 1-H); 7,31 (t, 1H, $J=7,3$ Hz, 4'-H); 7,37 (t, 2H, $J=7,3$ Hz, 3'H és 5'-H); 7,45 (d, 2H, $J=7,3 \mathrm{~Hz}, 2$ '-H és 6'-H).

137: ${ }^{1} \mathrm{H}$ NMR $\left(\mathrm{CDCl}_{3}\right): \delta$ ppm: $1,05\left(\mathrm{~s}, 3 \mathrm{H}, 18-\mathrm{H}_{3}\right) ; 2,69$ és 3,07 (2xm, 2x1H, 6- $\left.\mathrm{H}_{2}\right) ; 5,13$ (s, $\left.2 \mathrm{H}, \mathrm{OCH}_{2}\right) ; 6,76(\mathrm{~d}, 1 \mathrm{H}, J=8,7 \mathrm{~Hz}, 2-\mathrm{H}) ; 7,11(\mathrm{~d}, 1 \mathrm{H}, J=8,7 \mathrm{~Hz}, 1-\mathrm{H}) ; 7,3-7,46$ (átfedő multipletek, 5H, 2'-H, 3'-H, 4'-H; 5'-H, 6'-H).

36: ${ }^{1} \mathrm{H}$ NMR $\left(\mathrm{CDCl}_{3}\right)$ : $\delta$ ppm: 1,02 (s, 3H, 18- $\left.\mathrm{H}_{3}\right) ; 2,84\left(\mathrm{~m}, 1 \mathrm{H}, 6-\mathrm{H}_{2}\right) ; 6,10(\mathrm{~s}, 1 \mathrm{H}, 4-\mathrm{H})$; $6,21(\mathrm{dd}, 1 \mathrm{H}, J=10,2 \mathrm{~Hz}, J=1,8 \mathrm{~Hz}, 2-\mathrm{H}) ; 7,3-7,46$ (d, 5H, $J=10,2 \mathrm{~Hz}, 1-\mathrm{H})$.

138: ${ }^{1} \mathrm{H}$ NMR (DMSO-d $\left.{ }_{6}\right) \delta$ ppm: 0,92(s, 3H, 18- $\left.\mathrm{H}_{3}\right) ; 2,65\left(\mathrm{~m}, 2 \mathrm{H}, 6-\mathrm{H}_{2}\right) ; 6,62(\mathrm{~s}, 1 \mathrm{H}, 4-\mathrm{H})$; 7,17(s, 1H, 1-H); 9,71(s, 1H, OH); ${ }^{13} \mathrm{C}$ NMR (DMSO-d 6 ) $\delta$ ppm: 20,3; 26,4; 27,2; 27,7; 29,2; 29,7(C-18); 33,0; 35,2; 40,4; 41,4(C-13); 41,5; 51,0; 116,1(C-4); 116,9(C-2); 126,8(C-1); 132,1(C-10); 136,4(C-5); 150,3(C-3). MS ${ }^{\mathrm{II}} \mathrm{m} / \mathrm{z}(\%): 289\left(100, \mathrm{M}^{+}\right)$.

139: ${ }^{1} \mathrm{H}$ NMR (DMSO-d 6 ) $\delta$ ppm: 0,92(s, 3H, 18- $\left.\mathrm{H}_{3}\right) ; 2,52$ és 2,82(2xm, 2x1H, 6- $\left.\mathrm{H}_{2}\right) ; 6,76(\mathrm{~d}$, $1 \mathrm{H}, J=8,3 \mathrm{~Hz}, 2-\mathrm{H}) ; 7,09(\mathrm{~d}, 1 \mathrm{H}, J=8,3 \mathrm{~Hz}, 1-\mathrm{H}) ; 9,69(\mathrm{~s}, 1 \mathrm{H}, \mathrm{OH}) ;{ }^{13} \mathrm{C}$ NMR $\left(\right.$ DMSO-d $\left._{6}\right) \delta$ ppm: 20,4; 26,6; 27,2; 27,6; 28,3;29,6(C-18);32,9; 35,2; 39,8; 41,3(C-13); 41,8; 50,9; 113,4(C-2); 120,4(C-4); 124,6(C-1); 132,3(C-10); 135,1(C-5); 150,6(C-3). MS ${ }^{\mathrm{I}} \mathrm{m} / \mathrm{z}(\%): 289$ $\left(100,[\mathrm{M}-\mathrm{H}]^{-}\right)$.

140: ${ }^{1} \mathrm{H}$ NMR (DMSO-d $\left.\mathrm{d}_{6}\right) \delta$ ppm: 0,92(s, 3H, 18- $\left.\mathrm{H}_{3}\right) ; 2,55$ és 2,80(2xm, 2x1H, 6- $\left.\mathrm{H}_{2}\right) ; 7,27(\mathrm{~s}$, $1 \mathrm{H}, 1-\mathrm{H}) ; 9,66(\mathrm{~s}, 1 \mathrm{H}, \mathrm{OH}) ; 13 \mathrm{C}$ NMR (DMSO-d6) $\delta$ ppm: 20,7; 26,8; 27,5; 27,6; 28,6; 29,9(C-18); 33,2; 35,4; 39,9; 41,7(C-13); 42,0; 51,2; 119,4 és 122,5(C-2 és C-4); 125,6(C-1); 134,3(C-10); 134,8(C-5); 146,8(C-3). $\mathrm{MS}^{\mathrm{I}} \mathrm{m} / \mathrm{z}(\%): 353$ (100); $323\left(34,[\mathrm{M}-\mathrm{H}]^{-}\right)$. 
141: ${ }^{1} \mathrm{H}$ NMR (DMSO-d $\mathrm{d}_{6}$ ): $\delta$ ppm: 0,96 (s, 3H, 18- $\mathrm{H}_{3}$ ); 2,55 és 2,72 (2xm, $2 \mathrm{x} 1 \mathrm{H}, 6-\mathrm{H}_{2}$ ); 7,41 (s, 1H, 1-H); 9,49 (s, 1H, OH); ${ }^{13} \mathrm{C}$ NMR (DMSO-d 6 ): $\delta$ ppm: 20,3; 24,3 (C-18); 28,1; 28,3; 31,4; 32,8; 37,2; 39,7; 40,7; 48,1; 49,2; 96,5 (C-2); 107,3 (C-4); 129,8 (C-1); 134,8 (C-10); 139,8 (C-5); 150,4 (C-3); 220,3 (C-17).

142: ${ }^{1} \mathrm{H}$ NMR (DMSO-d $\left.\mathrm{d}_{6}\right): \delta$ ppm: 0,98 (s, $\left.3 \mathrm{H}, 18-\mathrm{H}_{3}\right) ; 2,58$ és $2,81\left(2 \mathrm{xm}, 2 \mathrm{x} 1 \mathrm{H}, 6-\mathrm{H}_{2}\right) ; 7,58$ (s, $1 \mathrm{H}, 1-\mathrm{H}$ ); 9,21 (s, 1H, OH). ${ }^{13} \mathrm{C}$ NMR (DMSO-d 6 ): $\delta$ ppm: 20,2; 24,2 (C-18); 27,3; 27,9; 31,$1 ; 31,2 ; 32,6 ; 39,6 ; 40,3 ; 48,0 ; 48,9(\mathrm{C}-13) ; 83,7$ (C-2); 115,8 (C-4); 131,4 (C-1); 135,4 (C10); 137,2 (C-5); 150,3 (C-3); 219,8 (C-17). 
III. A vegyületek fizikai adatai

\begin{tabular}{|c|c|c|c|c|c|}
\hline Szám & Vegyület képlete & $\begin{array}{c}\text { Összegképlet } \\
\text { Molekulatömeg }\end{array}$ & $\begin{array}{c}\text { Hozam } \\
(\%)\end{array}$ & Op. $\left({ }^{\circ} \mathrm{C}\right)$ & $\mathbf{R}_{\mathbf{f}}$ \\
\hline $144 a$ & & $\begin{array}{c}\mathrm{C}_{26} \mathrm{H}_{26} \mathrm{O}_{2} \\
370,19\end{array}$ & 86 & $159-161$ & $0,40^{\mathrm{b}}$ \\
\hline $144 b$ & & $\begin{array}{c}\mathrm{C}_{27} \mathrm{H}_{28} \mathrm{O}_{2} \\
384,21\end{array}$ & 89 & $181-183$ & $0,45^{\mathrm{b}}$ \\
\hline $144 c$ & & $\begin{array}{c}\mathrm{C}_{27} \mathrm{H}_{28} \mathrm{O}_{3} \\
400,20\end{array}$ & 84 & $169-171$ & $0,29^{\mathrm{b}}$ \\
\hline 144d & & $\begin{array}{c}\mathrm{C}_{26} \mathrm{H}_{25} \mathrm{FO}_{2} \\
388,18\end{array}$ & 84 & $206-208$ & $0,38^{\mathrm{b}}$ \\
\hline $144 e$ & & $\begin{array}{c}\mathrm{C}_{27} \mathrm{H}_{25} \mathrm{~F}_{3} \mathrm{O}_{2} \\
438,18\end{array}$ & 88 & $175-177$ & $0,33^{\mathrm{b}}$ \\
\hline $146 a$ & & $\begin{array}{c}\mathrm{C}_{27} \mathrm{H}_{28} \mathrm{O}_{2} \\
384,21\end{array}$ & 98 & $148-149$ & $0,46^{\mathrm{b}}$ \\
\hline $146 b$ & & $\begin{array}{c}\mathrm{C}_{28} \mathrm{H}_{30} \mathrm{O}_{2} \\
398,22\end{array}$ & 90 & $83-85$ & $0,48^{\mathrm{b}}$ \\
\hline $146 c$ & & $\begin{array}{c}\mathrm{C}_{28} \mathrm{H}_{30} \mathrm{O}_{3} \\
414,22\end{array}$ & 83 & $77-79$ & $0,38^{\mathrm{b}}$ \\
\hline 146d & & $\begin{array}{c}\mathrm{C}_{27} \mathrm{H}_{27} \mathrm{FO}_{2} \\
402,20\end{array}$ & 97 & $162-164$ & $0,44^{\mathrm{b}}$ \\
\hline $146 e$ & & $\begin{array}{c}\mathrm{C}_{28} \mathrm{H}_{27} \mathrm{~F}_{3} \mathrm{O}_{2} \\
452,20\end{array}$ & 81 & $131-132$ & $0,42^{\mathrm{b}}$ \\
\hline
\end{tabular}




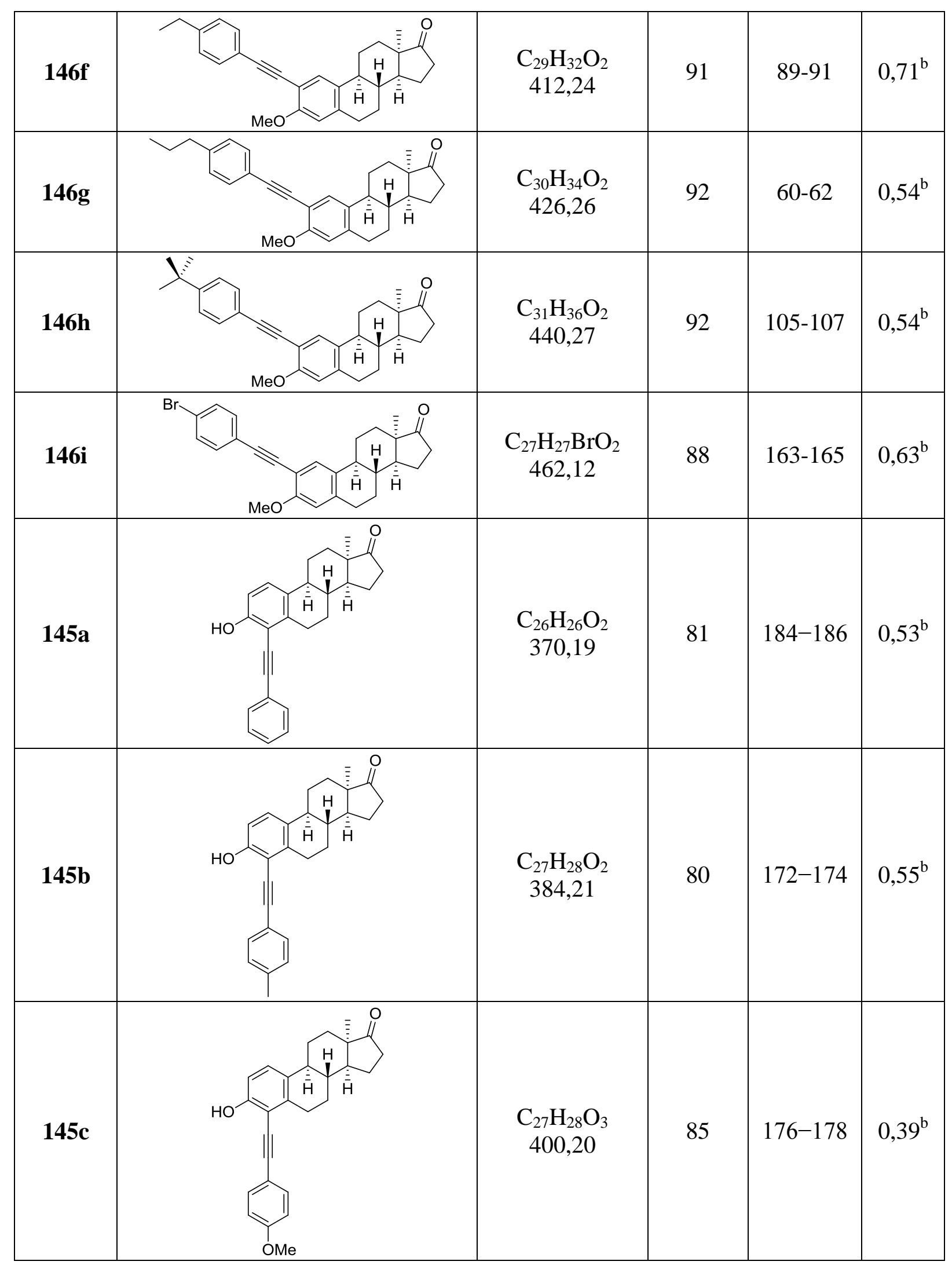




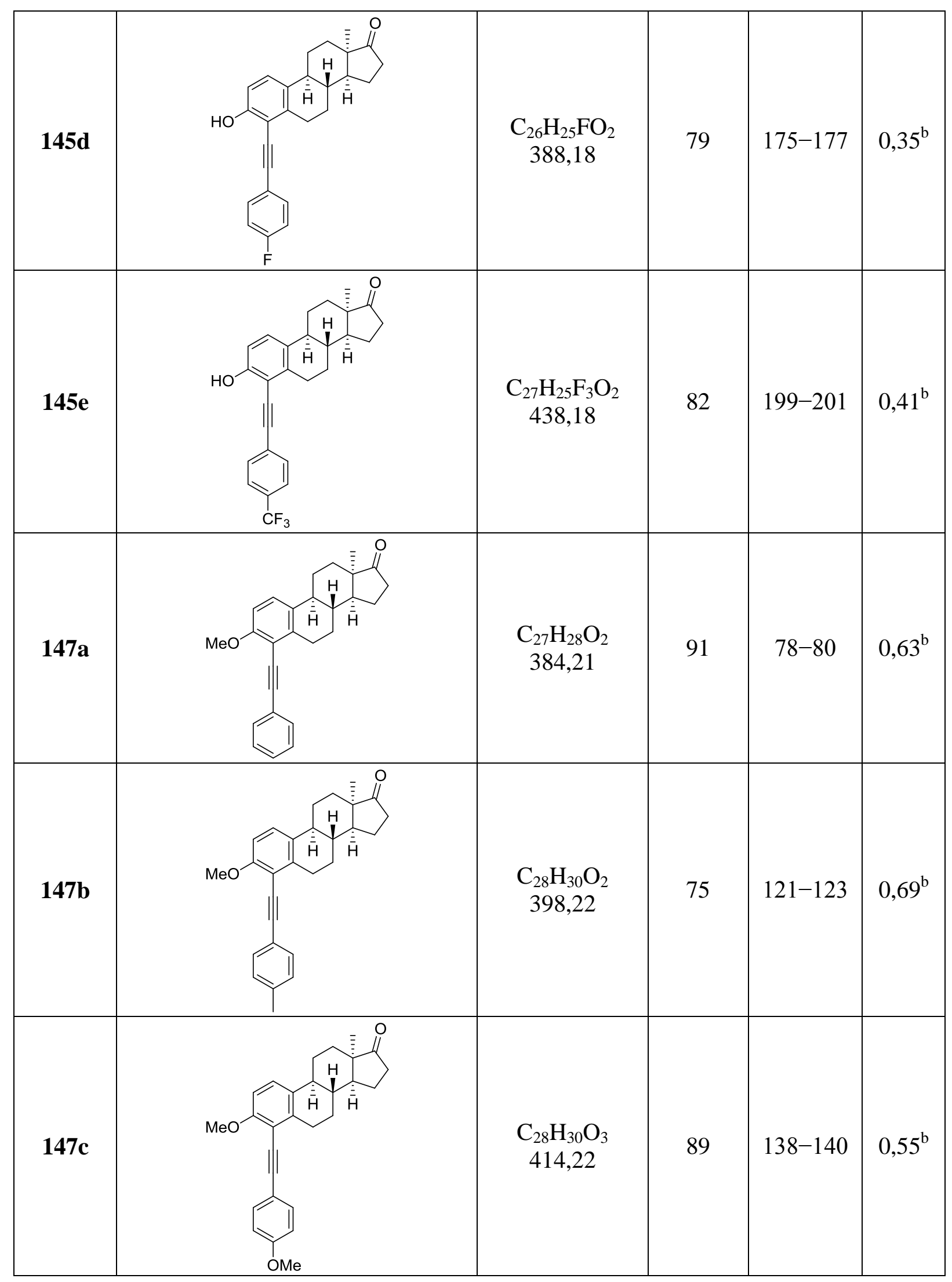




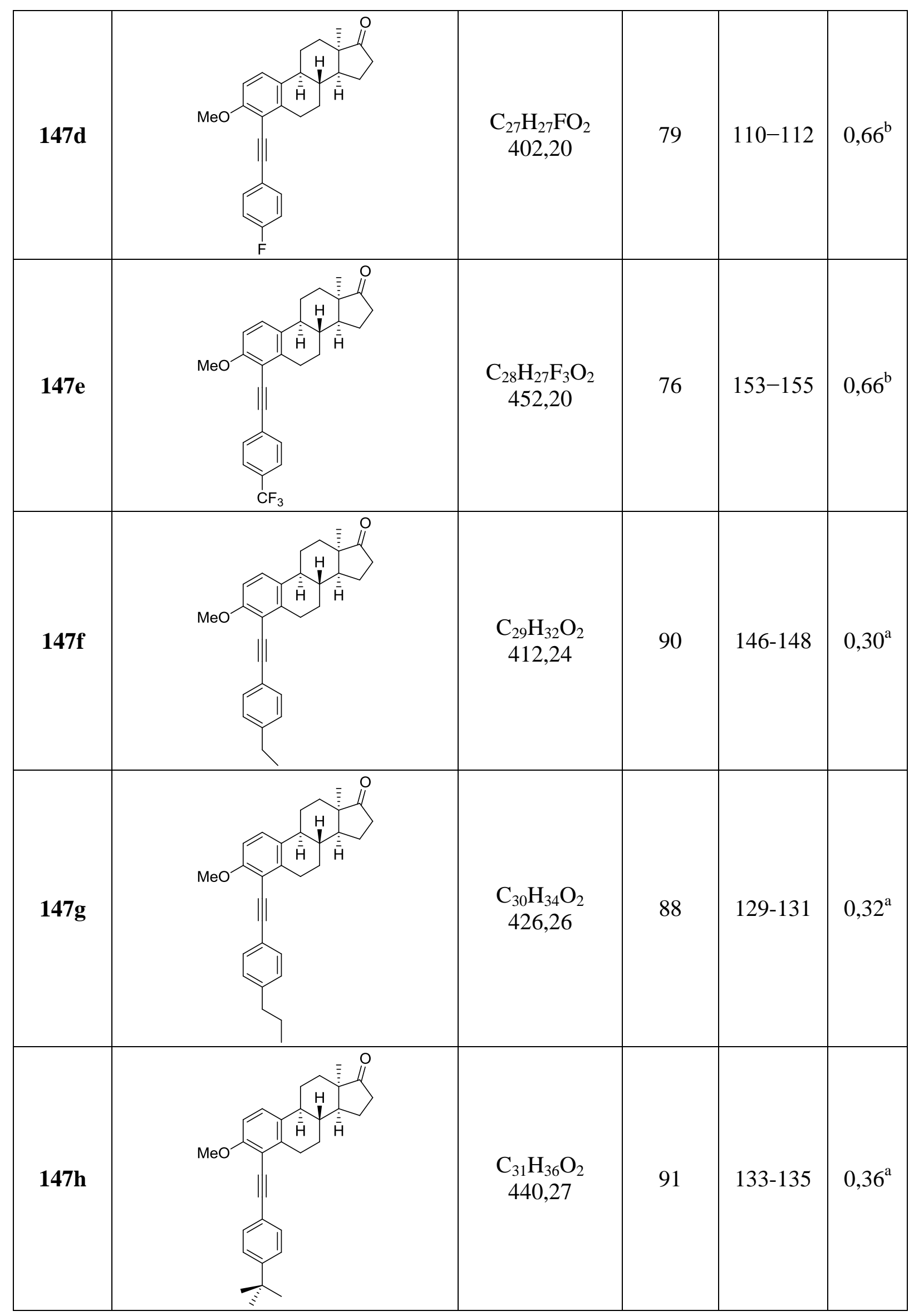




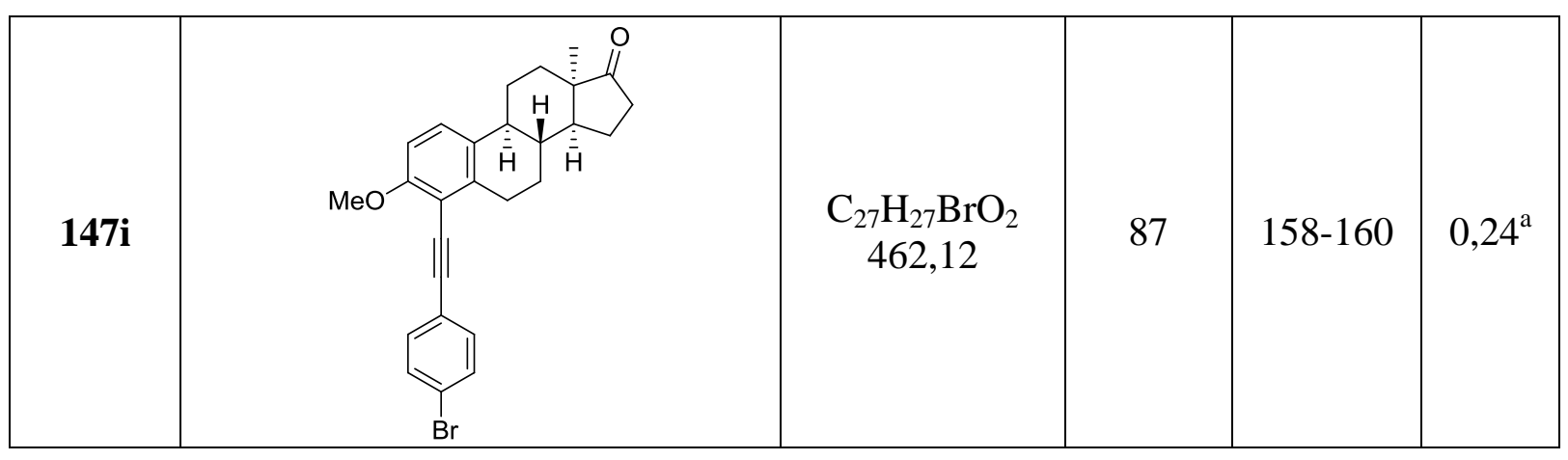


IV. A vegyületek NMR adatai

144a ${ }^{1} \mathrm{H}$ NMR $\left(\mathrm{CDCl}_{3}\right) \delta \mathrm{ppm}: 1,05\left(\mathrm{~s}, 3 \mathrm{H}, 18-\mathrm{H}_{3}\right) ; 2,82\left(\mathrm{~m}, 2 \mathrm{H}, 6-\mathrm{H}_{2}\right) ; 5,66(\mathrm{~s}, 1 \mathrm{H}, \mathrm{OH})$; 6,68(s, 1H, 4-H); 7,32(s, 1H, 1-H); 7,34 és 7,52(2x átfedő multipletek, 3H és 2H, 2"-H, 3"--H, 4 "-H, 5"-H és 6"-H); ${ }^{13} \mathrm{C}$ NMR $\left(\mathrm{CDCl}_{3}\right) \delta$ ppm : 21,01; 25,1(C-18); 28,1; 28,2; 30,3; 31,9; 33,4; 41,2; 41,3; 49,3; 50,1(C-13); 83,5 és 95,4(2x1C, C-2a és C-2b); 107,1(C-2); 114,3(C4); 122,6(C-1"); 128,4 és 131,5(2x2C: C-2”, C-3”, C-5”, C-6”); 128,5 és 129,1(C-1, C-4”); 132,1(C-10); 140,0(C-5); 154,2(C-3); 221,5(C-17). MS m/z (\%): $371\left(100,[\mathrm{M}+\mathrm{H}]^{+}\right)$.

144b ${ }^{1} \mathrm{H}$ NMR (DMSO-d 6 ) $\delta$ ppm : 0,96(s, 3H, 18- $\left.\mathrm{H}_{3}\right) ; 2,32\left(\mathrm{~s}, 3 \mathrm{H}, 4\right.$ "'- $\left.\mathrm{CH}_{3}\right) ; 2,70(\mathrm{~m}, 2 \mathrm{H}, 6-$ $\left.\mathrm{H}_{2}\right)$; 6,57(s, 1H, 4-H); 7,20 és 7,38(2xd, 2x2H, $J=7,9 \mathrm{~Hz}, 2$ "-H, 3"-H, 5"-H, és 6"-H); 7,22(s, 1H, 1-H); 9,59(s, 1H, OH); ${ }^{13} \mathrm{C}$ NMR $\delta$ ppm : 20,4; 20,9(4"- $\left.\mathrm{CH}_{3}\right) ; 24,5(\mathrm{C}-18) ; 27,5$; 27,$9 ; 29,6 ; 31,4 ; 32,8 ; 40,4 ; 40,6 ; 48,4 ; 49,3(\mathrm{C}-13) ; 86,6$ és 91,6(2x1C; C-2a és C-2b); 107,4(C-2); 114,9(C-4); 120,2(C-1"); 129,1 és 130,9(2x2C: C-2”, C-3”, C-5", C-6”); 130,1(C-1); 130,4(C-4”); 137,6(C-10); 138,9(C-5); 155,6(C-3); 220,5(C-17). MS m/z (\%): $385\left(100,[\mathrm{M}+\mathrm{H}]^{+}\right)$.

144c ${ }^{1} \mathrm{H}$ NMR (DMSO-d $\left.{ }_{6}\right) \delta \mathrm{ppm}: 0,96\left(\mathrm{~s}, 3 \mathrm{H}, 18-\mathrm{H}_{3}\right) ; 2,70\left(\mathrm{~m}, 2 \mathrm{H}, 6-\mathrm{H}_{2}\right) ; 3,77(\mathrm{~s}, 3 \mathrm{H}$, 4 "- $\left.\mathrm{OCH}_{3}\right)$; 6,57(s, 1H, 4-H); 6,95 és 7,42(2xd, 2x2H, $J=7,8 \mathrm{~Hz}, 2$ "-H, 3"-H, 5"-H, 6"-H); 7,20(s, 1H, 1-H); 9,54(s, $1 \mathrm{H}, \mathrm{OH}) ;{ }^{13} \mathrm{C}$ NMR $\delta$ ppm : 20,4; 24,4(C-18); 27,5; 27,9; 29,5; 31,5; 32,8; 40,4; 40,6; 48,4; 49,3(C-13); 55,1(4"- $\left.-\mathrm{OCH}_{3}\right) ; 85,7$ és 91,4(2x1C, C-2a és C-2b); 107,6(C-2); 114,1 és 132,5(2x2C: C-2”, C-3”, C-5”, C-6”); 114,1(C-4); 115,2(C-1”); 129,9(C-1); 130,3(C-10); 138,7(C-5); 155,5(C-3); 158,9(C-4”); 220,5(C-17); MS m/z (\%): $401\left(100,[\mathrm{M}+\mathrm{H}]^{+}\right)$

144d ${ }^{1} \mathrm{H}$ NMR (DMSO-d 6 ) $\delta$ ppm : 0,96(s, 3H, 18- $\left.\mathrm{H}_{3}\right) ; 2,71\left(\mathrm{~m}, 2 \mathrm{H}, 6-\mathrm{H}_{2}\right) ; 6,58(\mathrm{~s}, 1 \mathrm{H}, 4-\mathrm{H})$; 7,24 és 7,54(2x átfedő multipletek, 3H+2H, 1-H, 2"-H, 3"-H, 5"-H, 6"-H); 9,62(s, 1H, OH); ${ }^{13} \mathrm{C}$ NMR $\delta$ ppm : 20,6; 24,5(C-18); 27,5; 27,9; 29,6; 31,5; 32,8; 40,4; 40,5; 48,5; 49,3(C-13); 86,9 és 90,4(2x1C, C-2a és C-2b); 107,1(C-2); 115,0(C-4); 115,7(d, 2C, J=22,0 Hz C-3", C5”); 119,6(C-1"); 130,1(C-1); 130,4(C-10); 133,2(d, 2C, J = 8,5 Hz C-2", C-6”); 139,2(C-5); 155,7(C-3); 162,5(d, J=244 Hz; C-4”); 220,4(C-17). MS m/z (\%): $389\left(100,[\mathrm{M}+\mathrm{H}]^{+}\right)$.

144e ${ }^{1} \mathrm{H}$ NMR $\left(\mathrm{CDCl}_{3}\right) \delta \mathrm{ppm}: 1,06\left(\mathrm{~s}, 3 \mathrm{H}, 18-\mathrm{H}_{3}\right) ; 2,82\left(\mathrm{~m}, 2 \mathrm{H}, 6-\mathrm{H}_{2}\right) ; 5,64(\mathrm{~s}, 1 \mathrm{H}, \mathrm{OH})$; 6,68(s, 1H, 4-H); 7,33(s, 1H, 1-H); 7,61(s, 4H, 2"-H, 3"-H, 5"-H, 6"-H); ${ }^{13} \mathrm{C}$ NMR $\delta$ ppm : 21,$0 ; 25,0(\mathrm{C}-18) ; 28,0 ; 28,2 ; 30,3 ; 31,9 ; 33,4 ; 41,2 ; 41,3 ; 49,3 ; 50,1(\mathrm{C}-13) ; 86,3$ és 93,8(2x1C, C-2a és C-2b); 106,5(C-2); 114,6(C-4); 123,8(d, $\left.J=272,2 \mathrm{~Hz}, \mathrm{CF}_{3}\right) ; 125,3$ és 
131,6(2x2C: C-2", C-3", C-5", C-6”); 126,5(C-1”); 129,4(C-1); 130,1(d, J = 32,7 Hz, C-4”); 132,3(C-10); 140,7(C-5); 154,4(C-3); 221,5(C-17). MS m/z (\%): $439\left(100,[\mathrm{M}+\mathrm{H}]^{+}\right)$.

146a ${ }^{1} \mathrm{H}$ NMR (DMSO-d $\left.{ }_{6}\right) \delta$ ppm : 0,97(s, 3H, 18- $\left.\mathrm{H}_{3}\right) ; 2,81\left(\mathrm{~m}, 2 \mathrm{H}, 6-\mathrm{H}_{2}\right) ; 3,80(\mathrm{~s}, 3 \mathrm{H}$, 3- $\left.\mathrm{OCH}_{3}\right) ; 6,75(\mathrm{~s}, 1 \mathrm{H}, 4-\mathrm{H}) ; 7,33(\mathrm{~s}, 1 \mathrm{H}, 1-\mathrm{H}) ; 7,41$ és 7,49(2x átfedő multipletek, $3 \mathrm{H}$ és $2 \mathrm{H}$, 2"-H, 3"-H, 4"-H, 5"-H, 6"-H); ${ }^{13} \mathrm{C}$ NMR $\delta$ ppm : 20,3; 24,4(C-18); 27,4; 27,8; 29,9; 31,5; 32,$8 ; 40,4 ; 40,5 ; 48,4 ; 49,3(\mathrm{C}-13) ; 55,5\left(3-\mathrm{OCH}_{3}\right) ; 86,7$ és 91,8(2x1C, C-2a és C-2b); 108,6(C-2); 111,1(C-4); 122,9(C-1”); 128,2(C-4); 128,5 és 131,0(2x2C: C-2”, C-3”, C-5”, C6”); 130,5(C-1"); 131,6(C-10); 139,5(C-5); 157,3(C-3); 220,4(C-17). MS m/z (\%): 385 (100, $\left.[\mathrm{M}+\mathrm{H}]^{+}\right)$.

146b ${ }^{1} \mathrm{H}$ NMR $\left(\right.$ DMSO-d $\left._{6}\right) \delta$ ppm : 0,96(s, 3H, 18- $\left.\mathrm{H}_{3}\right) ; 2,32\left(\mathrm{~s}, 3 \mathrm{H}, 4\right.$ " $\left.-\mathrm{CH}_{3}\right) ; 2,80(\mathrm{~m}, 2 \mathrm{H}, 6-$ $\left.\mathrm{H}_{2}\right)$; 3,79(s, 3H, 3- $\left.\mathrm{OCH}_{3}\right)$; 6,73(s, 1H, 4-H); 7,20 és 7,37(2xd, 2x2H, J = 7,9 Hz, 2"-H, 3"-H, 5"-H, 6"-H); 7,31(s, 1H, 1-H); ${ }^{13} \mathrm{C}$ NMR $\delta$ ppm : 20,3; 20,9(4"- $\left.\mathrm{CH}_{3}\right) ; 24,4(\mathrm{C}-18) ; 27,4 ; 27,9$; 29,9; 31,5; 32,8; 40,4; 40,5; 48,4; 49,3(C-13); 55,4(3- $\left.\mathrm{OCH}_{3}\right)$; 86,0 és 91,9(2x1C C-2a és C2b); 108,8(C-2); 111,0(C-4); 119,9(C-1"); 129,1 és 130,9(2x2C: C-3", C-5”, C-2”, C-6”); 130,4(C-1); 131,5(C-10); 137,8(C-4”); 139,2(C-5); 157,1(C-3); 220,4(C-17). MS m/z (\%): $105(66) ; 399\left(100,[\mathrm{M}+\mathrm{H}]^{+}\right)$.

146c ${ }^{1} \mathrm{H}$ NMR $\left(\right.$ DMSO-d $\left._{6}\right) \delta$ ppm : 0,97(s, 3H, 18- $\left.\mathrm{H}_{3}\right) ; 2,80\left(\mathrm{~m}, 2 \mathrm{H}, 6-\mathrm{H}_{2}\right) ; 3,78(\mathrm{~s}, 6 \mathrm{H}$, 3- $\mathrm{OCH}_{3}$ és 4"- $\left.\mathrm{OCH}_{3}\right)$; 6,73(s, 1H, 4-H); 6,95 és 7,42(2xd, 2x2H, $J=8,7 \mathrm{~Hz}, 2$ "-H, 3"-H, 5"H, 6"-H); 7,30(s, 1H, 1-H); ${ }^{13} \mathrm{C}$ NMR $\delta$ ppm : 20,3; 24,4(C-18); 27,4; 27,9; 29,9; 31,5; 32,8; 40,4; 40,5; 48,4; 49,3(C-13); 55,1 és 55,4(2C: 3- $\mathrm{OCH}_{3}$ és 4"- $\left.\mathrm{OCH}_{3}\right)$; 85,1 és 91,8(2x1C C2a és C-2b); 109,0(C-2); 111,0(C-4); 114,2 és 132,5(2x2C: C-2”, C-3”, C-5", C-6”); 114,9(C-1”); 130,3(C-1); 131,5(C-10); 132,5(2C: C-2”, C-6”); 139,0(C-5); 157,1 és 159,1(C3 és C-4”); 220,4(C-17). MS m/z (\%):400 (100); $415\left(80,[\mathrm{M}+\mathrm{H}]^{+}\right)$.

146d ${ }^{1} \mathrm{H}$ NMR (DMSO-d $\left.{ }_{6}\right) \delta \mathrm{ppm}: 0,96\left(\mathrm{~s}, 3 \mathrm{H}, 18-\mathrm{H}_{3}\right) ; 2,81\left(\mathrm{~m}, 2 \mathrm{H}, 6-\mathrm{H}_{2}\right) ; 3,79(\mathrm{~s}, 3 \mathrm{H}$, $\left.3-\mathrm{OCH}_{3}\right) ; 6,74(\mathrm{~s}, 1 \mathrm{H}, 4-\mathrm{H}) ; 7,24$ és 7,54(2xdd, 2x2H, $J=8,7 \mathrm{~Hz}, J=5,7 \mathrm{~Hz}, 2$ '-H, 3"-H, 5"H, 6"-H); 7,33(s, 1H, 1-H); ${ }^{13} \mathrm{C}$ NMR $\delta$ ppm: 20,5; 24,6(C-18); 27,6; 28,0; 30,1; 31,7; 32,9; 40,5; 40,6; 48,6; 49,5(C-13); 55,6(3- $\left.\mathrm{OCH}_{3}\right) ; 86,6$ és 90,9(2x1C C-2a és C-2b); 108,6(C-2); 111,2(C-4); 115,9(2C, d, $J=22$ Hz, C-3" és C-5"); 119,5(C-1"); 130,6(C-1); 131,8(C-10); 133,4(2C, d, $J=8,4$ Hz, C-2”, és C-6”); 139,7(C-5); 157,4(C-3); 161,8(d, J = 247 Hz, C-4”); 220,6(C-17). MS m/z (\%): $403\left(100,[\mathrm{M}+\mathrm{H}]^{+}\right)$. 
146e ${ }^{1} \mathrm{H}$ NMR (DMSO-d $\left.{ }_{6}\right) \delta \mathrm{ppm}: 0,97\left(\mathrm{~s}, 3 \mathrm{H}, 18-\mathrm{H}_{3}\right) ; 2,82\left(\mathrm{~m}, 2 \mathrm{H}, 6-\mathrm{H}_{2}\right) ; 3,81(\mathrm{~s}, 3 \mathrm{H}$, $\left.3-\mathrm{OCH}_{3}\right) ; 6,78(\mathrm{~s}, 1 \mathrm{H}, 4-\mathrm{H}) ; 7,39(\mathrm{~s}, 1 \mathrm{H}, 1-\mathrm{H}) ; 7,69(\mathrm{~d} ; J=8,1 \mathrm{~Hz} ; 2 \mathrm{H}, 2$ '-H, 6"-H); 7,75(d; $J$ $=8,1 \mathrm{~Hz}, 2 \mathrm{H}, 3$ "-H, 5"-H); ${ }^{13} \mathrm{C}$ NMR $\delta$ ppm : 20,4; 24,5(C-18); 27,4; 27,9; 30,0; 31,5; 32,8; 40,4; 48,4; 49,4(C-13); 55,6(3- $\left.\mathrm{OCH}_{3}\right) ; 89,6(2 \mathrm{a}) ; 90,5(2 \mathrm{~b}) ; 107,9(\mathrm{C}-2) ; 111,2(\mathrm{C}-4) ; 123,8(\mathrm{~d}$, $\left.J=272,2 \mathrm{~Hz}, \mathrm{CF}_{3}\right)$ 125,5 és 131,7(2x2C: C-2", C-3", C-5", C-6”); 126,5(C-1”); 130,1(d, J= $32,8 \mathrm{~Hz}, \mathrm{C}-4$ ”) 130,8(C-1); 131,8(C-10); 140,3(C-5); 157,5(C-3); 220,5(C-17). MS m/z $(\%): 289(44) ; 453\left(100,[\mathrm{M}+\mathrm{H}]^{+}\right)$.

146f ${ }^{1} \mathrm{H}$ NMR (DMSO-d $\left.\mathrm{d}_{6}\right) \delta$ ppm 0,96(s, 3H, 18- $\left.\mathrm{H}_{3}\right) ; 1,17\left(\mathrm{t}, 3 \mathrm{H}, \mathrm{CH}_{2}-\mathrm{C}_{3}\right) ; 2,62(\mathrm{dd}, 2 \mathrm{H}$, $\left.\mathrm{C}_{2}-\mathrm{CH}_{3}\right) ; 2,80\left(\mathrm{~m}, 2 \mathrm{H}, 6-\mathrm{H}_{2}\right) ; 3,78\left(\mathrm{~s}, 3 \mathrm{H}, \mathrm{OCH}_{3}\right) ; 6,73(\mathrm{~s}, 1 \mathrm{H}, 4-\mathrm{H}) ; 7,23(\mathrm{~m}, 2 \mathrm{H}, 2$ '-H és 6'-

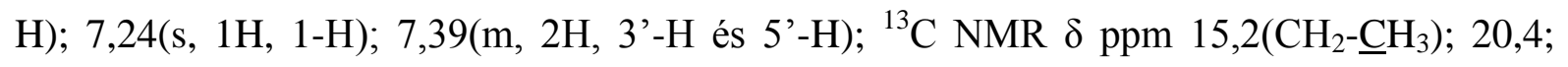
24,5(C-18); 27,5; 28,0;28,8; 29,9; 31,5; 32,8;40,4; 40,5;48,4; 49,3; 55,5( $\left(\mathrm{OCH}_{3}\right) ; 86,1$ és 92,0(2C: C $\equiv \mathrm{C}) ; 108,8(\mathrm{C}-2) ; 111,1(\mathrm{C}-4) ; 120,2(\mathrm{C}-1$ '); 127,9 (2C: C-3' és C-5'); 130,4 (C-1); 130,9 (2C: C-2' és C-6’); 139,3 (C-10); 140,0 (C-5); 144,1 (C-4'); 157,2 (C-3); 220,5 (C-17).

146g ${ }^{1} \mathrm{H}$ NMR (DMSO-d $\left.\mathrm{d}_{6}\right) \delta$ ppm 0,88(t, 3H, $\left.\mathrm{CH}_{2-} \mathrm{C}_{3}\right) ; 0,96\left(\mathrm{~s}, 3 \mathrm{H}, 18-\mathrm{H}_{3}\right) ; 2,57(\mathrm{t}, 2 \mathrm{H}, 4$ '$\left.\mathrm{CH}_{2}\right) ; 2,81\left(\mathrm{~m}, 2 \mathrm{H}, 6-\mathrm{H}_{2}\right) ; 3,79\left(\mathrm{~s}, 3 \mathrm{H}, \mathrm{OCH}_{3}\right) ; 6,74(\mathrm{~s}, 1 \mathrm{H}, 4-\mathrm{H}) ; 7,21(\mathrm{~d}, 2 \mathrm{H}, J=7,9 \mathrm{~Hz}, 3$ '-H, $\left.5^{\prime}-\mathrm{H}\right) ; 7,31(\mathrm{~s}, 1 \mathrm{H}, 1-\mathrm{H}) ; 7,38\left(\mathrm{~d}, 2 \mathrm{H}, J=7,9 \mathrm{~Hz}, 2{ }^{\prime}-\mathrm{H}, 6{ }^{\prime}-\mathrm{H}\right) ;{ }^{13} \mathrm{C}$ NMR $\delta$ ppm $13,6\left(\mathrm{CH}_{2}{ }^{-}\right.$ $\left.\underline{\mathrm{CH}}_{3}\right) ; 20,5 ; 23,4 ; 24,6(\mathrm{C}-18) ; 27,6 ; 28,1 ; 30,1 ; 31,6 ; 33,0 ; 37,1 ; 40,5 ; 40,6 ; 48,6 ; 49,5$; 55,6( $\left(\mathrm{OCH}_{3}\right) ; 86,2$ és 92,1(2C: $\left.\mathrm{C} \equiv \mathrm{C}\right) ; 109,0(\mathrm{C}-2) ; 111,2(\mathrm{C}-4) ; 120,4(\mathrm{C}-1$ '); 128,7(2C: C-3', C-5'); 130,5(C-1); 131,1(2C: C-2', C-6'); 131,7(C-10); 139,4(C-5); 142,6(C-4'); 157,4(C-3); 220,6(C-17).

146h ${ }^{1} \mathrm{H}$ NMR (DMSO-d $\left.{ }_{6}\right) \delta$ ppm 0,97(s, 3H, 18- $\left.\mathrm{H}_{3}\right) ; 1,28\left(\mathrm{~s}, 9 \mathrm{H}, 4{ }^{\prime}-\mathrm{C}\left(\mathrm{C}_{\mathrm{H}_{3}}\right)_{3}\right) ; 2,81(\mathrm{~m}, 2 \mathrm{H}$, 6- $\left.\mathrm{H}_{2}\right) ; 3,79\left(\mathrm{~s}, 3 \mathrm{H}, \mathrm{OCH}_{3}\right) ; 6,74(\mathrm{~s}, 1 \mathrm{H}, 4-\mathrm{H}) ; 7,32(\mathrm{~s}, 1 \mathrm{H}, 1-\mathrm{H}) ; 7,41\left(\mathrm{~m}, 4 \mathrm{H}, 2^{\prime}-\mathrm{H}, 3^{\prime}-\mathrm{H}, 5^{\prime}-\mathrm{H}\right.$, 6'-H); ${ }^{13} \mathrm{C}$ NMR $\delta$ ppm, 20,3; 24,4(C-18); 27,4; 27,9 29,9; 30,8(3C, 4'-C( CH$\left.\left._{3}\right)_{3}\right) ; 31,5$; $32,8\left(4^{\prime}-\underline{\mathrm{C}}\left(\mathrm{CH}_{3}\right)_{3}\right) ; 40,4 ; 40,5 ; 48,4 ; 49,3 ; 55,5\left(\mathrm{OCH}_{3}\right) ; 86,0$ és 91,9(2C: $\left.\mathrm{C} \equiv \mathrm{C}\right) ; 108,8(\mathrm{C}-2)$; 111,1(C-4); 120,0(C-1'); 125,3(2C: C-3', C-5'); 130,4(C-1); 130,8(2C: C-2', C-6'); 131,6(C10); 139,3(C-5); 150,9(C-4'); 157,2(C-3); 220,4(C-17).

146i ${ }^{1} \mathrm{H}$ NMR (DMSO-d $\left.{ }_{6}\right) \delta$ ppm $0,97\left(\mathrm{~s}, 3 \mathrm{H}, 18-\mathrm{H}_{3}\right) ; 2,81\left(\mathrm{~m}, 2 \mathrm{H}, 6-\mathrm{H}_{2}\right) ; 3,79(\mathrm{~s}, 3 \mathrm{H}$, $\left.\mathrm{OCH}_{3}\right) ; 6,76$ (s, 1H, 4-H); 7,35 (s, 1H, 1-H); 7,43 (m, 2H, 2'-H és 6'-H); 7,59 (m, 2H, 3'-H és 5 '-H); ${ }^{13} \mathrm{C}$ NMR $\delta$ ppm 20,$3 ; 24,5(\mathrm{C}-18) ; 27,4 ; 27,9 ; 29,9 ; 31,5 ; 32,8 ; 40,4 ; 40,5 ; 48,4$; 49,3; 55,5( $\left(\mathrm{OCH}_{3}\right) ; 61.5 ; 88,0$ és 90,7(2C: $\left.\mathrm{C} \equiv \mathrm{C}\right) ; 108,2(\mathrm{C}-2) ; 111,1(\mathrm{C}-4) ; 121,5$ és 122,1(2C: C-1',C-4'); 130,6(C-1); 131,6(2C: C3', C-5'); 131,7(C-10); 132,9(2C: C-3', C-5'); 139,8(C$5) ; 157,3(\mathrm{C}-3) ; 220,5(\mathrm{C}-17)$. 
145a ${ }^{1} \mathrm{H}$ NMR (DMSO-d $\left.{ }_{6}\right) \delta$ ppm : 0,96(s, 3H, 18- $\left.\mathrm{H}_{3}\right) ; 2,76$ és 3,02(2xm, 2x1H, 6- $\left.\mathrm{H}_{2}\right)$; $6,69(\mathrm{~d}, 1 \mathrm{H}, J=8,5 \mathrm{~Hz}, 2-\mathrm{H}) ; 7,12(\mathrm{~d}, 1 \mathrm{H}, J=8,5 \mathrm{~Hz}, 1-\mathrm{H}) ; 7,39$ és 7,50(2x átfedő multipletek, 3H és 2H, 2"-H, 3"-H, 4"-H, 5"-H, 6"-H); 9,62(s, 1H OH); ${ }^{13} \mathrm{C}$ NMR $\delta$ ppm : 20,$4 ; 24,4(\mathrm{C}-18) ; 27,5 ; 27,9 ; 28,8 ; 31,5 ; 32,8 ; 40,2 ; 40,7 ; 48,3 ; 49,3(\mathrm{C}-13) ; 85,4$ és 97,3(2x1C, C-4a és C-4b); 108,7(C-4); 112,7(C-2); 123,3(C-1”); 127,1 és 128,0(C-1, C-4”); 128,5 és 130,9(2x2C: C-2”, C-3”, C-5" C-6”); 130,4(C-10); 139,5(C-5); 156,2(C-3); 220,6(C-17);

145b ${ }^{1} \mathrm{H}$ NMR (DMSO-d $\left.{ }_{6}\right) \delta \mathrm{ppm}: 0,96\left(\mathrm{~s}, 3 \mathrm{H}, 18-\mathrm{H}_{3}\right) ; 2,33\left(\mathrm{~s}, 3 \mathrm{H}, 4\right.$ "- $\left.-\mathrm{OCH}_{3}\right) ; 2,74$ és 3,01(2xm, 2x1H, 6- $\left.\mathrm{H}_{2}\right) ; 6,68(\mathrm{~d}, 1 \mathrm{H}, J=8,5 \mathrm{~Hz}, 2-\mathrm{H}) ; 7,11(\mathrm{~d}, 1 \mathrm{H}, J=8,5 \mathrm{~Hz}, 1-\mathrm{H}) ; 7,21$ és 7,38(2xd, 2x2H, J=7,7 Hz, 2"-H, 3"-H, 5"-H, 6"-H); 9,57(s, 1H, OH); ${ }^{13} \mathrm{C}$ NMR $\delta$ ppm : 20,$4 ; 20,9\left(4 "-\mathrm{CH}_{3}\right) ; 24,4(\mathrm{C}-18) ; 27,5 ; 27,9 ; 28,8 ; 31,5 ; 32,8 ; 40,2 ; 40,7 ; 48,3 ; 49,3(\mathrm{C}-13)$; 84,7 és 97,4(2x1C, C-4a és C-4b); 108,9(C-4); 112,6(C-2); 120,3(C-4”); 126,9(C-1); 129,1 és 130,8 (2x2C: C-2”, C-3", C-5”, C-6”); 130,3(C-10); 137,7(C-1”); 139,4(C-5); 156,1(C-3); 220,6(C-17). MS m/z (\%): $385\left(100,[\mathrm{M}+\mathrm{H}]^{+}\right)$.

145c ${ }^{1} \mathrm{H}$ NMR $\left(\mathrm{CDCl}_{3}\right) \delta \mathrm{ppm}: 1,05\left(\mathrm{~s}, 3 \mathrm{H}, 18-\mathrm{H}_{3}\right) ; 2,82$ és 3,12(2xm, 2x1H, 6- $\left.\mathrm{H}_{2}\right) ; 3,83(\mathrm{~s}$, $3 \mathrm{H}, 4$ " $\left.-\mathrm{OCH}_{3}\right) ; 5,77(\mathrm{~s}, 1 \mathrm{H}, \mathrm{OH}) ; 6,78(\mathrm{~d}, 1 \mathrm{H}, J=8,5 \mathrm{~Hz}, 2-\mathrm{H}) ; 6,88$ és 7,45(2xd, 2x2H, $J=$ 7,1 Hz, 2"-H, 3"-H, 5"-H, 6"-H); 7,17(d, 1H, $J=8,5 \mathrm{~Hz}, 1-\mathrm{H}) ;{ }^{13} \mathrm{C}$ NMR $\delta$ ppm : 21,0; 25,1(C-18); 28,1; 28,3; 29,3; 32,0; 33,4; 41,1; 41,5; 49,2; 50,1(C-13); 55,3(4"-- $\left.\mathrm{OCH}_{3}\right) ; 80,7$ és 100,7(2x1C, C-4a és C-4b); 109,1(C-4); 111,7(C-2); 114,1 és 132,9(2x2C: C-2”, C-3”, C5", C-6”); 114,7(C-4”); 127,3(C-1); 131,7(C-10); 138,9(C-5); 154,5(C-3); 159,9(C-4”); 221,6(C-17). MS m/z (\%): $401\left(100,[\mathrm{M}+\mathrm{H}]^{+}\right)$.

145d ${ }^{1} \mathrm{H}$ NMR (DMSO-d 6 ) $\delta$ ppm : 0,96(s, 3H, 18- $\left.\mathrm{H}_{3}\right) ; 2,75$ és 3,01(2xm, 2x1H, 6- $\left.\mathrm{H}_{2}\right)$; $6,68(\mathrm{~d}, 1 \mathrm{H}, J=8,5 \mathrm{~Hz}, 2-\mathrm{H}) ; 7,12(\mathrm{~d}, 1 \mathrm{H}, J=8,5 \mathrm{~Hz}, 1-\mathrm{H}) ; 7,24$ és 7,54(2x multipletek, 2x2H, 2"-H, 3"-H, 5"-H, 6"-H); 9,61(s, 1H, OH); ${ }^{13} \mathrm{C}$ NMR $\delta$ ppm : 20,4; 24,4(C-18); 27,5; 27,9; 28,8; 31,5; 32,8; 40,2; 40,7; 48,3; 49,3(C-13); 85,1 és 96,1(2x1C, C-4a és C-4b); 108,6(C-4); 112,7(C-2); 115,8(d, 2C, $J=22,1$ Hz C-3" és C-5”); 119,7(C-1”); 127,2(C-1); 130,3(C-10); 133,1(d, 2C, $J=8,5 \mathrm{~Hz}, \mathrm{C}-2$ " és C-6”); 139,5(C-5); 156,3(C-3); 161,6(d, J= $247 \mathrm{~Hz}, \mathrm{C}-4 ”)$; 220,6(C-17). MS m/z (\%): 123 (53); 389(100, [M+H] $\left.]^{+}\right)$.

145e ${ }^{1} \mathrm{H}$ NMR (DMSO-d $\left.\mathrm{d}_{6}\right) \delta \mathrm{ppm}: 0,96\left(\mathrm{~s}, 3 \mathrm{H}, 18-\mathrm{H}_{3}\right) ; 2,77$ és 3,03(2xm, 2x1H, 6- $\left.\mathrm{H}_{2}\right)$; 6,72(d, 1H, $J=8,5 \mathrm{~Hz}, 4-\mathrm{H}) ; 7,16(\mathrm{~d}, 1 \mathrm{H}, J=8,5 \mathrm{~Hz}, 1-\mathrm{H}) ; 7,70(\mathrm{~d}, 2 \mathrm{H}, J=7,9 \mathrm{~Hz}, 2$ '-H, 6"- 
$\mathrm{H}) ; 7,76\left(\mathrm{~d}, 2 \mathrm{H}, J=7,9 \mathrm{~Hz}, 3\right.$ "'-H, 5"-H); 9,75(s, 1H, OH); ${ }^{13} \mathrm{C}$ NMR $\delta \mathrm{ppm}: 20,4 ; 24,4(\mathrm{C}-$ 18); 27,5; 27,9; 28,8; 31,5; 32,8; 40,1; 40,7; 48,3; 49,3(C-13); 88,3 és 95,8(2x1C, C-4a és C4b); 108,2(C-4); 112,8(C-2); 125,4 és 125,5 és 131,6(1C+1C+2C, C-2”, C-3”, C-5”, C-6”); 127,5(C-1"); 123,8(d, $\left.J=272,2 \mathrm{~Hz}, \mathrm{CF}_{3}\right) ; 127,8(\mathrm{C}-1) ; 130,4(\mathrm{C}-10) ; 139,5(\mathrm{C}-5) ; 133,7(\mathrm{~d}, J=$ $32,8 \mathrm{~Hz}, \mathrm{C}-4 ”) ; 156,6(\mathrm{C}-3) ; 220,5(\mathrm{C}-17)$. MS m/z (\%): $439\left(100,[\mathrm{M}+\mathrm{H}]^{+}\right)$.

147a ${ }^{1} \mathrm{H}$ NMR $\left(\right.$ DMSO-d $\left._{6}\right) \delta$ ppm : 0,96(s, 3H, 18- $\left.\mathrm{H}_{3}\right) ; 2,78$ és 3,04(2xm, 2x1H, 6- $\left.\mathrm{H}_{2}\right)$; 3,79(s, 3H, 3- $\left.\mathrm{OCH}_{3}\right) ; 6,86(\mathrm{~d}, 1 \mathrm{H}, J=8,8 \mathrm{~Hz}, 2-\mathrm{H}) ; 7,30(\mathrm{~d}, 1 \mathrm{H}, J=8,8 \mathrm{~Hz}, 1-\mathrm{H}) ; 7,40(2 \mathrm{x}$ átfedő multipletek, $3 \mathrm{H}$ és $2 \mathrm{H}, 2$ "'-H, 3"-H, 4"-H, 5"-H, 6"-H); ${ }^{13} \mathrm{C}$ NMR $\delta$ ppm : 20,4; 24,4(C-18); 27,4; 27,9; 28,7; 31,5; 32,8; 40,1; 40,7; 48,3; 49,3(C-13); 55,5(3- $\left.\mathrm{OCH}_{3}\right) ; 84,8$ és 97,8(2x1C, C-4a és C-4b); 108,4(C-2); 110,1(C-4); 123,0(C-1"); 127,2 és 128,2(C-1 és C4”); 128,5 és 130,9(2x2C: C-2”, C-3”, C-5”, C-6”); 132,0(C-10); 140,0(C-5); 157,7(C-3); 220,5(C-17). MS m/z (\%): $385\left(100,[\mathrm{M}+\mathrm{H}]^{+}\right)$.

147b ${ }^{1} \mathrm{H}$ NMR (DMSO-d 6 ) $\delta$ ppm : 0,96(s, 3H, 18- $\left.\mathrm{H}_{3}\right) ; 2,32\left(\mathrm{~s}, 3 \mathrm{H}, 4\right.$ "'- $\left.\mathrm{CH}_{3}\right) ; 2,76$ és 3,02(m, $\left.2 \mathrm{H}, 6-\mathrm{H}_{2}\right) ; 3,78\left(\mathrm{~s}, 3 \mathrm{H}, 3-\mathrm{OCH}_{3}\right) ; 6,83(\mathrm{~d}, 1 \mathrm{H}, J=8,8 \mathrm{~Hz}, 2-\mathrm{H}) ; 7,21$ és 7,37(2xd, 2x2H, $J=$ 7,9 Hz, 2"-H, 3"-H, 5"-H, 6"-H); 7,26(d, 1H, J = 8,8 Hz, 1-H); ${ }^{13} \mathrm{C}$ NMR $\delta$ ppm : 20,6; 21,1; 24,4(C-18); 27,6; 28,1; 29,0; 31,6; 33,0; 40,3; 40,9; 48,5; 49,4(C-13); 55,7( $\left(\mathrm{OCH}_{3}\right) ; 84,3$ és 98,2(2x1C, C-4a és C-4b); 108,6(C-2); 110,5(C-4); 120,2(C-1”); 127,2(C-1); 129,4 és 131,0(2x2C: C-2”, C-3”, C-5”, C-6”); 132,2(C-10); 138,1(C-5); 140,1(C-4”); 157,9(C-3); 220,7(C-17). MS m/z (\%): $399\left(100,[\mathrm{M}+\mathrm{H}]^{+}\right)$.

147c ${ }^{1} \mathrm{H}$ NMR (DMSO-d 6 ) $\delta$ ppm : 0,97(s, 3H, 18- $\left.\mathrm{H}_{3}\right) ; 2,76$ és 3,02(2xm, 2x1H, 6- $\left.\mathrm{H}_{2}\right)$; $3,79\left(\mathrm{~s}, 6 \mathrm{H}, 3-\mathrm{OCH}_{3}\right.$ és 4 " $\left.-\mathrm{OCH}_{3}\right) ; 6,83(\mathrm{~d}, 1 \mathrm{H}, J=8,7 \mathrm{~Hz}, 2-\mathrm{H}) ; 6,98$ és 7,42(2xd, $2 \times 2 \mathrm{H}, J=$ $8,8 \mathrm{~Hz}, 2$ "'-H, 3"-H, 5"-H, 6"-H); 7,26(d, 1H, $J=8,7 \mathrm{~Hz}, 1-\mathrm{H}) ;{ }^{13} \mathrm{C}$ NMR $\delta$ ppm : 20,4; 24,4(C-18); 27,5; 28,0; 28,8; 31,5; 32,9; 40,1; 40,8; 48,3; 49,3(C-13); 55,2 és 55,5(3-OCH és 4"- $\left.\mathrm{OCH}_{3}\right) ; 83,4$ és 97,9(2x1C, C-4a és C-4b); 108,4(C-2); 110,6(C-4); 114,3 és 132,5(2x2C: C-2", C-3”, C-5”, C-6”); 115,0(C-1”); 126,9(C-1); 132,0(C-10); 139,8(C-5); 157,6 és 159,1(C-3 és C-4”); 220,6(C-17). MS m/z (\%): $415\left(100,[\mathrm{M}+\mathrm{H}]^{+}\right)$.

147d ${ }^{1} \mathrm{H}$ NMR (DMSO-d 6 ) $\delta$ ppm : 0,97(s, 3H, 18- $\left.\mathrm{H}_{3}\right) ; 2,77$ és 3,03(2xm, 2x1H, 6- $\left.\mathrm{H}_{2}\right)$; 3,79(s, 3H, 3- $\left.\mathrm{OCH}_{3}\right) ; 6,85(\mathrm{~d}, 1 \mathrm{H}, J=8,7 \mathrm{~Hz}, 2-\mathrm{H}) ; 7,24(\mathrm{~d}, 1 \mathrm{H}, 1-\mathrm{H}) ; 7,26(\mathrm{dd}, 2 \mathrm{H}, J=13,6$ $\mathrm{Hz}, J=8,8 \mathrm{~Hz}, 3$ "-H, 5"-H); 7,54(dd, $2 \mathrm{H}, J=8,8 \mathrm{~Hz}, J=5,5 \mathrm{~Hz}, 2$ "-H, 6"-H) ${ }^{13} \mathrm{C} \mathrm{NMR} \delta$ ppm : 20,4; 24,4(C-18);27,4;27,9;28,8; 31,5; 32,8;40,1;40,7;48,3; 49,3(C-13); $55,5\left(3-\mathrm{OCH}_{3}\right) ; 84,5$ és 96,7(2x1C, C-4a és C-4b); 108,4(C-2); 110,0(C-4); 115,8(d, 2C, $J=$ 22,1 Hz, C-3”, C-5”); 119,4(C-1); 127,3(C-1”); 132,0(C-10); 133,2(d, 2C, J = 8,5 Hz, C-2”, 
C-6"); 140,0(C-5); 157,8(C-3); 161,7(d, $J=247 \mathrm{~Hz}, \mathrm{C}-4$ "); 220,5(C-17). MS m/z (\%): 403 $\left(100,[\mathrm{M}+\mathrm{H}]^{+}\right)$.

147e ${ }^{1} \mathrm{H}$ NMR (DMSO-d $\left.\mathrm{d}_{6}\right) \delta \mathrm{ppm}: 0,97\left(\mathrm{~s}, 3 \mathrm{H}, 18-\mathrm{H}_{3}\right) ; 2,81$ és 3,04(2xm, 2x1H, 6- $\left.\mathrm{H}_{2}\right)$; 3,81(s, 3H, 3- $\left.-\mathrm{OCH}_{3}\right) ; 6,88(\mathrm{~d}, 1 \mathrm{H}, J=8,7 \mathrm{~Hz}, 2-\mathrm{H}) ; 7,33(\mathrm{~d}, 1 \mathrm{H}, J=8,7 \mathrm{~Hz}, 1-\mathrm{H}) ; 7,70$ és 7,77(2x átfedő multipletek, 2x2H, 2"-H, 3"-H, 5"-H, 6"-H); ${ }^{13} \mathrm{C}$ NMR $\delta$ ppm : 20,4; 24,4(C18); 27,4; 27,9; 28,8; 31,5; 32,9; 40,1;40,7;48,3; 49,3(C-13); 55,6( $\left(\mathrm{OCH}_{3}\right) ; 87,7$ és 96,4(2x1C, C-4a és C-4b); 108,5(C-2); 109,4(C-4); 120,1(C-1”); 125,5 és 131,7(2x2C: C-2”, C-3", C-5", C-6"); 127,3(C-1); 128,0(C-4”); 132,2(C-10); 140,4(C-5); 158,1(C-3); 220,6(C17). MS m/z (\%): $453\left(100,[\mathrm{M}+\mathrm{H}]^{+}\right)$.

147f ${ }^{1} \mathrm{H}$ NMR (DMSO-d $\left.{ }_{6}\right) \delta$ ppm 0,97 (s, 3H, 18- $\mathrm{H}_{3}$ ); 1,18 (t, 3H, $\left.J=7,5 \mathrm{~Hz}, \mathrm{CH}_{2}-\underline{\mathrm{C}}_{3}\right) ; 2,77$ és $3,02\left(\mathrm{~m}, 2 \mathrm{H}, 6-\mathrm{H}_{2}\right) ; 3,79\left(\mathrm{~s}, 3 \mathrm{H}, \mathrm{OCH}_{3}\right) ; 6,85(\mathrm{~d}, 1 \mathrm{H}, J=8,6 \mathrm{~Hz}, 2-\mathrm{H}) ; 7,25(\mathrm{~m}, 3 \mathrm{H}, 2$ '$\left.\mathrm{H}, 6^{\prime}-\mathrm{H}, 1-\mathrm{H}\right) ; 7,40\left(\mathrm{~m}, 2 \mathrm{H}, 3^{\prime}-\mathrm{H}, 5^{\prime}-\mathrm{H}\right) ;{ }^{13} \mathrm{C} \mathrm{NMR} \delta \mathrm{ppm} 15,3\left(\mathrm{CH}_{2}-\mathrm{CH}_{3}\right) ; 20,4 ; 24,4(\mathrm{C}-18)$; 27,$5 ; 28,00 ; 28,8(2 \mathrm{C}) ; 31,5 ; 32,9 ; 40,8 ; 48,3 ; 49,3 ; 55,5\left(\mathrm{OCH}_{3}\right) ; 84,2$ és $98,0(2 \mathrm{C}: \mathrm{C} \equiv \mathrm{C})$; 108,4 (C-2); 110,3 (C-4); 120,3 (C-1'); 127,1 (C-1); 128,1 (2C: C-3' és C-5'); 131,0 (2C: C2' és C-6'); 132,0 (C-10); 140,0 (C-5); 144,3 (C-4'); 157,7 (C-3); 220,6 (C-17).

147g ${ }^{1} \mathrm{H}$ NMR (DMSO-d $\left.{ }_{6}\right) \delta$ ppm 0,89(t, 3H, $\left.J=7,2 \mathrm{~Hz}, \mathrm{CH}_{2}-\mathrm{C}_{3}\right) ; 0,97$ (s, 3H, 18- $\mathrm{H}_{3}$ ); 2,58(t, 7,2Hz, $\left.\underline{\mathrm{C}}_{2}-\mathrm{CH}_{3}\right) ; 2,77$ és 3,03 (m, 2H, 6- $\left.\mathrm{H}_{2}\right) ; 3,79\left(\mathrm{~s}, 3 \mathrm{H}, 3-\mathrm{OCH}_{3}\right) ; 6,85(\mathrm{~d}, 1 \mathrm{H}, J=$ 8,6 Hz, 2-H); 7,23(m, 2H, 2'-H,6'-H); 7,28(d, 1H, J = 8,6 Hz, 1-H); 7,40 (m, 2H, 3'-H,5'-H); ${ }^{13} \mathrm{C}$ NMR $\delta$ ppm 13,5 $\left(\mathrm{CH}_{2}-\mathrm{CH}_{2}-\underline{\mathrm{CH}}_{3}\right) ; 20,4 ; 23,8 ; 24,4(\mathrm{C}-18) ; 27,4 ; 28,0 ; 28,8 ; 31,5 ; 32,8$; 36,9; 40,1; 40,8; 48,3; 49,3; 55,5 $\left(\mathrm{OCH}_{3}\right) ; 84,2$ és 98,0 (2C: $\left.\mathrm{C} \equiv \mathrm{C}\right) ; 108,4(\mathrm{C}-2) ; 110,3(\mathrm{C}-4)$; 120,3 (C-1'); 127,1 (C-1); 128,6 (2C: C-3' és C-5'); 130,9 (2C: C-2' és C-6'); 132,0 (C-10); 139,9 (C-5); 142,6 (C-4'); 157,7 (C-3); 220,6 (C-17).

147h ${ }^{1} \mathrm{H}$ NMR (DMSO-d $\left.{ }_{6}\right) \delta$ ppm 0,97(s, 3H, 18- $\left.\mathrm{H}_{3}\right) ; 2,77$ és 3,03(m, 2H, 6- $\left.\mathrm{H}_{2}\right) ; 3,79(\mathrm{~s}, 3 \mathrm{H}$, $3-\mathrm{OCH}_{3} ; 6,85(\mathrm{~d}, 1 \mathrm{H}, J=8,7 \mathrm{~Hz}, 2-\mathrm{H}) ; 7,24(\mathrm{~d}, 1 \mathrm{H}, 1-\mathrm{H}) ; 7,26(\mathrm{dd}, 2 \mathrm{H}, J=8,8 \mathrm{~Hz}, J=13,6 \mathrm{~Hz}$, $2^{\prime}-\mathrm{H}, 6$ '-H); 7,54(dd, 2H, $J=5,5 \mathrm{~Hz}, J=8,5 \mathrm{~Hz}, 3^{\prime}$-H, ' $\left.^{\prime}-\mathrm{H}\right){ }^{13} \mathrm{C}$ NMR $\delta$ ppm 20,4; 24,4(C-18); 27,$4 ; 27,9 ; 28,8 ; 31,5 ; 32,8 ; 40,1 ; 40,7 ; 48,3 ; 49,3 ; 55,5\left(\mathrm{OCH}_{3}\right) ; 84,5$ és $96,7(2 \mathrm{C}: \mathrm{C} \equiv \mathrm{C})$; 108,4(C-2); 110,0(C-4); 115,7 és 115,9 (2C: C-3', C-5'); 119,4(C-1'); 127,3(C-1); 132,0(C10); 133,1 és 133,2 (2C:; C-2',C-6'); 140,0(C-5); 157,8(C-3); 160,7 és 162,7 (C-4', $J=$ $247 \mathrm{~Hz}) ; 220,4(\mathrm{C}-17)$.

147i ${ }^{1} \mathrm{H}$ NMR (DMSO-d 6 ) $\delta$ ppm 0,97(s, 3H, 18- $\mathrm{H}_{3}$ ); 2,77 és 3,03(m, 2H, 6- $\left.\mathrm{H}_{2}\right) ; 3,79(\mathrm{~s}, 3 \mathrm{H}$, $\left.3-\mathrm{OCH}_{3}\right) ; 6,85(\mathrm{~d}, 1 \mathrm{H}, J=8,7 \mathrm{~Hz}, 2-\mathrm{H}) ; 7,30(\mathrm{~d}, 1 \mathrm{H}, J=8,7 \mathrm{~Hz}, 1-\mathrm{H}) ; 7,43\left(\mathrm{~m}, 2 \mathrm{H}, 2^{\prime}-\mathrm{H}, 6\right.$ '-H); 
7,60(m, 2H, 3'-H,5'-H); ${ }^{13} \mathrm{C}$ NMR $\delta$ ppm 20,4; 24,4(C-18); 27,4; 27,9; 28,7; 31,5; 32,8; 40,1; 40,7; 48,3; 49,3; 55,5( $\left.\mathrm{OCH}_{3}\right) ; 86,1$ és 96,7(2C: $\left.\mathrm{C} \equiv \mathrm{C}\right) ; 108,5(\mathrm{C}-2) ; 109,8(\mathrm{C}-4) ; 121,6$ és 122,2 (2C: C-1',C-4'); 127,5(C-1); 131,6(2C: C-3',C-5'); 132,1(C-10); 132,8(2C: C-2',C-6'); 140,1(C-5); 157,8(C-3); 220,5(C-17). 
V. A vegyületek fizikai adatai

\begin{tabular}{|c|c|c|c|c|c|}
\hline Szám & Vegyület képlete & $\begin{array}{c}\text { Összegképlet } \\
\text { Molekulatömeg }\end{array}$ & $\begin{array}{c}\text { Hozam } \\
(\%)\end{array}$ & Op. $\left({ }^{\circ} \mathrm{C}\right)$ & $\mathbf{R}_{\mathbf{f}}$ \\
\hline 148 & & $\begin{array}{c}\mathrm{C}_{28} \mathrm{H}_{32} \mathrm{O}_{3} \\
416,24\end{array}$ & 84 & olajos & $0,55^{\mathrm{b}}$ \\
\hline 149 & & $\begin{array}{c}\mathrm{C}_{28} \mathrm{H}_{32} \mathrm{O}_{3} \\
416,24\end{array}$ & 76 & olajos & $0,60^{\mathrm{b}}$ \\
\hline 150 & & $\begin{array}{c}\mathrm{C}_{27} \mathrm{H}_{28} \mathrm{O}_{3} \\
400,20\end{array}$ & 92 & $95-97$ & $0,58^{b}$ \\
\hline 151 & & $\begin{array}{c}\mathrm{C}_{27} \mathrm{H}_{28} \mathrm{O}_{3} \\
400,20\end{array}$ & 94 & $147-150$ & $0,51^{b}$ \\
\hline 152 & & $\begin{array}{c}\mathrm{C}_{27} \mathrm{H}_{32} \mathrm{O}_{3} \\
404,24\end{array}$ & 80 & $134-136$ & $0,42^{b}$ \\
\hline 153 & & $\begin{array}{c}\mathrm{C}_{27} \mathrm{H}_{32} \mathrm{O}_{3} \\
404,24\end{array}$ & 80 & $157-159$ & $0,52^{b}$ \\
\hline 154 & & $\begin{array}{c}\mathrm{C}_{28} \mathrm{H}_{34} \mathrm{O}_{3} \\
418.25\end{array}$ & 84 & olajos & $0,60^{b}$ \\
\hline
\end{tabular}




\begin{tabular}{|l|l|l|l|l|}
\hline 155 & olajos & $0,62^{\mathrm{b}}$ \\
\hline
\end{tabular}




\section{A vegyületek NMR adatai}

$148{ }^{1} \mathrm{H}$ NMR $\left(\mathrm{CDCl}_{3}\right) \delta \mathrm{ppm}: 1,00\left(\mathrm{~s}, 3 \mathrm{H}, 18-\mathrm{H}_{3}\right) ; 2,82\left(\mathrm{~m}, 2 \mathrm{H}, 6-\mathrm{H}_{2}\right) ; 3,77$ és 3,79(2xs, $2 \times 3 \mathrm{H}, 3-\mathrm{OCH}_{3}$ és 4"- $\left.\mathrm{OCH}_{3}\right) ; 6,52(\mathrm{~s}, 2 \mathrm{H}, 2 \mathrm{a}-\mathrm{H}$ és $2 \mathrm{~b}-\mathrm{H}) ; 6,56(\mathrm{~s}, 1 \mathrm{H}, 4-\mathrm{H}) ; 6,71$ és 7,18(2xd, $2 \times 2 \mathrm{H}, J=8,6 \mathrm{~Hz}, 2$ "'-H, 3"-H, 5"-H, 6"-H); 7,15(s, 1H, 1-H); ${ }^{13} \mathrm{C}$ NMR $\delta$ ppm : 20,5; 24,7(C-18); 27,7; 27,8; 30,1; 31,6; 33,0; 40,9; 41,2; 48,8; 49,7(C-13); 54,8 és 55,1(4”--OCH és $\left.3-\mathrm{OCH}_{3}\right)$; 110,3(C-4); 113,1 és 129,5(2x2C: C-2", C-3", C-5", C-6"); 121,5(C-2); $123,6(\mathrm{C}-1) ; 127,4$ és $128,8(2 \times 1 C, C-2 a$ és C-2b); 129,6(C-1”); 130,8(C-10); 136,6(C-5); 154,7 és 158,1(C-3 és C-4”); 221,1(C-17). MS m/z (\%): $417\left(100,[\mathrm{M}+\mathrm{H}]^{+}\right)$.

$149{ }^{1} \mathrm{H}$ NMR $\left(\mathrm{CDCl}_{3}\right) \delta \mathrm{ppm}: 1,04\left(\mathrm{~s}, 3 \mathrm{H}, 18-\mathrm{H}_{3}\right) ; 2,47$ és 2,73(2xm, 2x1H, 6- $\left.\mathrm{H}_{2}\right) ; 3,66$ és 3,74(2xs, 2x3H, 3- $\mathrm{OCH}_{3}$ és 4" $\left.-\mathrm{OCH}_{3}\right)$; 6,30 és 6,61(2xd, 2x1H, $J=12,2 \mathrm{~Hz}, 2 \mathrm{a}-\mathrm{H}$ és $\left.2 \mathrm{~b}-\mathrm{H}\right)$; $6,67$ és 6,97(2xd, 2x2H, $J=8,6 \mathrm{~Hz}, 2$ "-H, 3"-H, 5"-H, 6"-H); 6,73(d, 1H, $J=8,6 \mathrm{~Hz}, 2-\mathrm{H})$; $7,21(\mathrm{~d}, 1 \mathrm{H}, J=8,6 \mathrm{~Hz}, 1-\mathrm{H}) ;{ }^{13} \mathrm{C}$ NMR $\delta$ ppm : 20,9; 25,0(C-18); 27,7; 28,3; 28,4; 29,7; 32,1; 33,4; 40,9; 41,6; 49,5; 50,1(C-13); 55,1 és 55,5(4"-- $\mathrm{OCH}_{3}$ és 3- $\left.\mathrm{OCH}_{3}\right) ; 108,4(\mathrm{C}-2) ; 113,4$ és 129,3(2x2C: C-2”, C-3", C-5”, C-6”); 123,0(C-1); 125,3 és 130,9(2x1C, C-2a és C-2b); 125,6(C-4); 130,5(C-10); 132,6(C-1"); 136,2(C-5); 154,7(C-3); 158,6(C-4”); 221,7(C-17). MS $m / z(\%): 417\left(100,[\mathrm{M}+\mathrm{H}]^{+}\right)$.

$150{ }^{1} \mathrm{H}$ NMR $\left(\mathrm{CDCl}_{3}\right) \delta \mathrm{ppm}: 1,07\left(\mathrm{~s}, 3 \mathrm{H}, 18-\mathrm{H}_{3}\right) ; 2,96\left(\mathrm{~m}, 2 \mathrm{H}, 6-\mathrm{H}_{2}\right) ; 3,85\left(\mathrm{~s}, 3 \mathrm{H}, 4{ }^{\prime}-\mathrm{OCH}_{3}\right)$; 6,79(s, 1H, 4'-H); 6,96(d, 2H, J=8,3 Hz, 2"-H, 6"-H); 7,19(s, 1H, 4-H); 7,43(s, 1H, 1-H); 7,76(d, 2H, $J=8,3 \mathrm{~Hz}, 3$ ”-H, 5"-H); ${ }^{13} \mathrm{C}$ NMR $\delta$ ppm : 21,2; 25,1(C-18); 28,4; 28,7; 30,6; 32,1; 33,5; 41,4; 41,8; 49,7; 50,2(C-13); 55,3(4"- $\left.\mathrm{OCH}_{3}\right)$; 99,6(C-4'); 110,1(C-4); 114,2 és 126,2(2x2C: C-2", C-3", C-5", C-6”); 117,2(C-1); 123,6(C-2); 127,6(C-1"); 133,6(C-5); 134,9(C-10); 153,4 és 155,6(C-3 és C-5'); 159,8(C-4”); 221,7(C-17). MS m/z (\%): 304 (53); $332(52) ; 401\left(100,[\mathrm{M}+\mathrm{H}]^{+}\right)$.

$151{ }^{1} \mathrm{H}$ NMR $\left(\mathrm{CDCl}_{3}\right) \delta \mathrm{ppm}: 1,08\left(\mathrm{~s}, 3 \mathrm{H}, 18-\mathrm{H}_{3}\right) ; 2,95$ és 3,08(2xm, 2x1H, 6- $\left.\mathrm{H}_{2}\right) ; 3,86(\mathrm{~s}$, $3 \mathrm{H}, 4$ "'- $\left.\mathrm{OCH}_{3}\right) ; 6,83(\mathrm{~s}, 1 \mathrm{H}, 4$ '-H); 6,96 és 7,78(2xd, 2x2H, J = 8,7 Hz, 2"-H, 3"-H, 5"-H, 6"$\mathrm{H}) ; 7,19(\mathrm{~d}, 1 \mathrm{H}, J=8,6 \mathrm{~Hz}, 1-\mathrm{H}) ; 7,28(\mathrm{~d}, 1 \mathrm{H}, J=8,6 \mathrm{~Hz}, 2-\mathrm{H}) ;{ }^{13} \mathrm{C}$ NMR $\delta \mathrm{ppm}: 21,1$; $25,1(\mathrm{C}-18) ; 27,3 ; 27,9 ; 28,8 ; 32,3 ; 33,5 ; 41,6 ; 42,0 ; 49,3 ; 50,1(\mathrm{C}-13) ; 55,3\left(4 "-\mathrm{OCH}_{3}\right)$; 98,1(C-4'); 108,4(C-2); 114,2 és 126,2(2x2C: C-2”, C-3”, C-5”, C-6”); 121,9(C-1); 123,5(C4); 128,5(C-1"); 128,9(C-5); 133,5(C-10); 152,7 és 155,8(C-5' és C-3); 159,8(C-4"); 221,6(C-17). MS m/z (\%):304 (73); $332(72) ; 401\left(100,[\mathrm{M}+\mathrm{H}]^{+}\right)$. 
$152{ }^{1} \mathrm{H}$ NMR $\left(\mathrm{CDCl}_{3}\right) \delta \mathrm{ppm}: 1,06\left(\mathrm{~s}, 3 \mathrm{H}, 18-\mathrm{H}_{3}\right) ; 2,74\left(\mathrm{~m}, 2 \mathrm{H}, 6-\mathrm{H}_{2}\right) ; 2,81\left(\mathrm{~m}, 4 \mathrm{H}, 2 \mathrm{a}-\mathrm{H}_{2}\right.$ és 2b- $\left.\mathrm{H}_{2}\right) ; 3,79\left(\mathrm{~s}, 3 \mathrm{H}, 4\right.$ "'- $\left.\mathrm{OCH}_{3}\right) ; 4,82(\mathrm{~s}, 1 \mathrm{H}, \mathrm{OH}) ; 6,47(\mathrm{~s}, 1 \mathrm{H}, 4-\mathrm{H}) ; 6,83(\mathrm{~d}, 2 \mathrm{H}, J=7,2 \mathrm{~Hz}, 3$ "H, 5"-H); 6,97(s, $1 \mathrm{H} \mathrm{1-H);} \mathrm{7,12(d,} \mathrm{2H,} J=7,2 \mathrm{~Hz}, 2$ "'-H, 6"-H); ${ }^{13} \mathrm{C}$ NMR $\delta$ ppm : 21,0; $25,1(\mathrm{C}-18) ; 28,3 ; 28,4 ; 29,8 ; 32,1 ; 32,6 ; 33,5 ; 35,6 ; 41,4 ; 41,6 ; 49,2 ; 50,2(\mathrm{C}-13)$; 55,3(4"- $\left.\mathrm{OCH}_{3}\right)$; 113,8 és 129,3(2x2C: C-2", C-3", C-5”, C-6”); 115,1(C-4); 125,5(C-2); 127,7(C-1); 131,8(C-10); 134,2(C-1”); 135,7(C-5); 151,5(C-3); 157,8(C-4”); 222,0(C-17). $\operatorname{MS} m / z(\%): 405\left(100,[\mathrm{M}+\mathrm{H}]^{+}\right)$.

$153{ }^{1} \mathrm{H}$ NMR $\left(\mathrm{CDCl}_{3}\right) \delta \mathrm{ppm}: 1,06\left(\mathrm{~s}, 3 \mathrm{H}, 18-\mathrm{H}_{3}\right) ; 2,63-2,85$ (átfedő multipletek, 6H, 6- $\mathrm{H}_{2}$ és $4 \mathrm{a}-\mathrm{H}_{2}$ és 4b- $\left.\mathrm{H}_{2}\right) ; 3,79\left(\mathrm{~s}, 3 \mathrm{H}, 4\right.$ "- $\left.-\mathrm{OCH}_{3}\right) ; 4,65(\mathrm{~s}, 1 \mathrm{H}, \mathrm{OH}) ; 6,61(\mathrm{~d}, 1 \mathrm{H}, J=8,3 \mathrm{~Hz}, 2-\mathrm{H}) ; 6,83$ és 7,12(2xd, 2x2H, $J=8,3 \mathrm{~Hz}, 2$ "-H, 3"-H, 5"-H, 6"-H); 7,03(d, 1H, $J=8,3 \mathrm{~Hz}, 1-\mathrm{H}) ;{ }^{13} \mathrm{C}$ NMR $\delta$ ppm : 21,1; 25,1(C-18); 27,1; 28,5(2C, C-4a és C-4b); 28,6; 32,1; 33,5; 34,3; 40,8; 41,8; 49,3; 50,1(C-13); 55,3(4"- $\left.\mathrm{OCH}_{3}\right) ; 112,9(\mathrm{C}-2)$; 113,8 és 129,3(2x2C: C-2”, C-3”; C-5", C-6”); 124,4(C-1); 125,7(C-4); 132,5(C-10); 134,4(C-1”); 136,4(C-5); 151,5(C-3); 157,8(C4”); 221,9(C-17). MS m/z (\%): 304 (100); 405 (72, [M+H] $\left.]^{+}\right) ; 445$ (94).

$154{ }^{1} \mathrm{H}$ NMR $\left(\mathrm{CDCl}_{3}\right) \delta \mathrm{ppm}: 1,06\left(\mathrm{~s}, 3 \mathrm{H}, 18-\mathrm{H}_{3}\right) ; 2,80$ (átfedő multipletek, 6H, 6- $\mathrm{H}_{2}$ és 2a- $\mathrm{H}_{2}$ és $\left.2 \mathrm{~b}-\mathrm{H}_{2}\right) ; 3,79$ és $3,80\left(2 \mathrm{xs}, 2 \times 3 \mathrm{H}, 3-\mathrm{OCH}_{3}\right.$ és 4 "- $\left.-\mathrm{OCH}_{3}\right) ; 6,55(\mathrm{~s}, 1 \mathrm{H}, 4-\mathrm{H}) ; 6,83$ és 7,13(2xd, 2x2H, $J=8,2 \mathrm{~Hz}, 2$ "-H, 3"-H, 5"-H, 6"-H); 6,99(s, 1H, 1-H); ${ }^{13} \mathrm{C}$ NMR $\delta$ ppm : 21,$0 ; 25,1(\mathrm{C}-18) ; 28,4(2 \mathrm{C}, \mathrm{C}-2 \mathrm{a}$ és C-2b); 30,3; 32,1; 32,7; 33,5; 35,6; 41,4; 41,7; 49,3; 50,1(C-13); 55,3 és 55,4(4"- $\mathrm{OCH}_{3}$ és 3- $\left.\mathrm{OCH}_{3}\right)$; 110,5(C-4); 113,6 és 129,3(2x2C: C-2", C3"; C-5", C-6"); 127,5(C-1); 127,9(C-2); 131,2(C-10); 134,7(C-1"); 135,3(C-5); 155,5(C-3); 157,7(C-4”); 221,6(C-17). MS m/z (\%): 401 (53); $419\left(100,[\mathrm{M}+\mathrm{H}]^{+}\right)$.

$155{ }^{1} \mathrm{H}$ NMR $\left(\mathrm{CDCl}_{3}\right) \delta \mathrm{ppm}: 1,06\left(\mathrm{~s}, 3 \mathrm{H}, 18-\mathrm{H}_{3}\right) ; 2,67$ és 2,85(2x átfedő multipletek, 2x3H, $6-\mathrm{H}_{2}$ és $4 \mathrm{a}-\mathrm{H}_{2}$ és $\left.4 \mathrm{~b}-\mathrm{H}_{2}\right) ; 3,80$ és 3,81(2xs, 2x3H, 3- $\mathrm{OCH}_{3}$ és 4"- $\left.\mathrm{OCH}_{3}\right) ; 6,74(\mathrm{~d}, 1 \mathrm{H}, J=8,5$ $\mathrm{Hz}, 2-\mathrm{H}) ; 6,84(\mathrm{~d}, 2 \mathrm{H}, J=7,3 \mathrm{~Hz}, 3$ "-H, 5"-H); 7,14(átfedő multipletek, 3H, 1-H , 2"-H, 6"$\mathrm{H}) ;{ }^{13} \mathrm{C}$ NMR $\delta$ ppm : 21,1; 25,1(C-18); 27,1; 28,5; 28,6; 32,1; 33,5; 34,4; 40,8; 41,8; 49,3; 50,1(C-13); 55,3 és 55,4(4" $-\mathrm{OCH}_{3}$ és 3- $\left.\mathrm{OCH}_{3}\right)$; 108,1(C-2); 113,6 és 129,2(2x2C: C-2", C3", C-5", C-6"); 124,1(C-1); 127,9(C-4); 132,3(C-10); 134,9(C-1"); 136,0(C-5); 155,4(C-3); 157,7(C-4”); 221,7(C-17). MS m/z (\%): 135 (100); 401 (91); $419\left(97,[\mathrm{M}+\mathrm{H}]^{+}\right)$. 
VII. A vegyületek fizikai adatai

\begin{tabular}{|c|c|c|c|c|c|}
\hline Szám & Vegyület képlete & $\begin{array}{c}\text { Összegképlet } \\
\text { Molekulatömeg }\end{array}$ & $\begin{array}{c}\text { Hozam } \\
(\%)\end{array}$ & Op. $\left({ }^{\circ} \mathrm{C}\right)$ & $\mathbf{R}_{\mathbf{f}}$ \\
\hline 157 & & $\begin{array}{c}\mathrm{C}_{25} \mathrm{H}_{29} \mathrm{NO}_{2} \\
375,22\end{array}$ & 85 & $174-176$ & $0,67^{d}$ \\
\hline $158 a$ & & $\begin{array}{c}\mathrm{C}_{26} \mathrm{H}_{31} \mathrm{NO}_{2} \\
389,24\end{array}$ & 84 & $168-170$ & $0,71^{\mathrm{d}}$ \\
\hline $158 b$ & & $\begin{array}{c}\mathrm{C}_{26} \mathrm{H}_{31} \mathrm{NO}_{3} \\
405,23\end{array}$ & 94 & $132-134$ & $0,53^{\mathrm{d}}$ \\
\hline $158 \mathrm{c}$ & & $\begin{array}{c}\mathrm{C}_{25} \mathrm{H}_{28} \mathrm{ClNO}_{2} \\
409,18\end{array}$ & 87 & $70-72$ & $0,67^{\mathrm{d}}$ \\
\hline 158d & & $\begin{array}{c}\mathrm{C}_{25} \mathrm{H}_{28} \mathrm{~N}_{2} \mathrm{O}_{4} \\
420,20\end{array}$ & 96 & $106-108$ & $0,55^{\mathrm{d}}$ \\
\hline $159 a$ & & $\begin{array}{c}\mathrm{C}_{26} \mathrm{H}_{31} \mathrm{NO}_{2} \\
389,24\end{array}$ & 83 & 106-107 & $0,69^{\mathrm{d}}$ \\
\hline 159b & & $\begin{array}{c}\mathrm{C}_{26} \mathrm{H}_{31} \mathrm{NO}_{3} \\
405,23\end{array}$ & 92 & $135-137$ & $0,51^{\mathrm{d}}$ \\
\hline 159c & & $\begin{array}{c}\mathrm{C}_{25} \mathrm{H}_{28} \mathrm{ClNO}_{2} \\
409,18\end{array}$ & 84 & $72-74$ & $0,51^{\mathrm{d}}$ \\
\hline 159d & & $\begin{array}{c}\mathrm{C}_{25} \mathrm{H}_{28} \mathrm{~N}_{2} \mathrm{O}_{4} \\
420,20\end{array}$ & 92 & $52-54$ & $0,47^{\mathrm{d}}$ \\
\hline
\end{tabular}




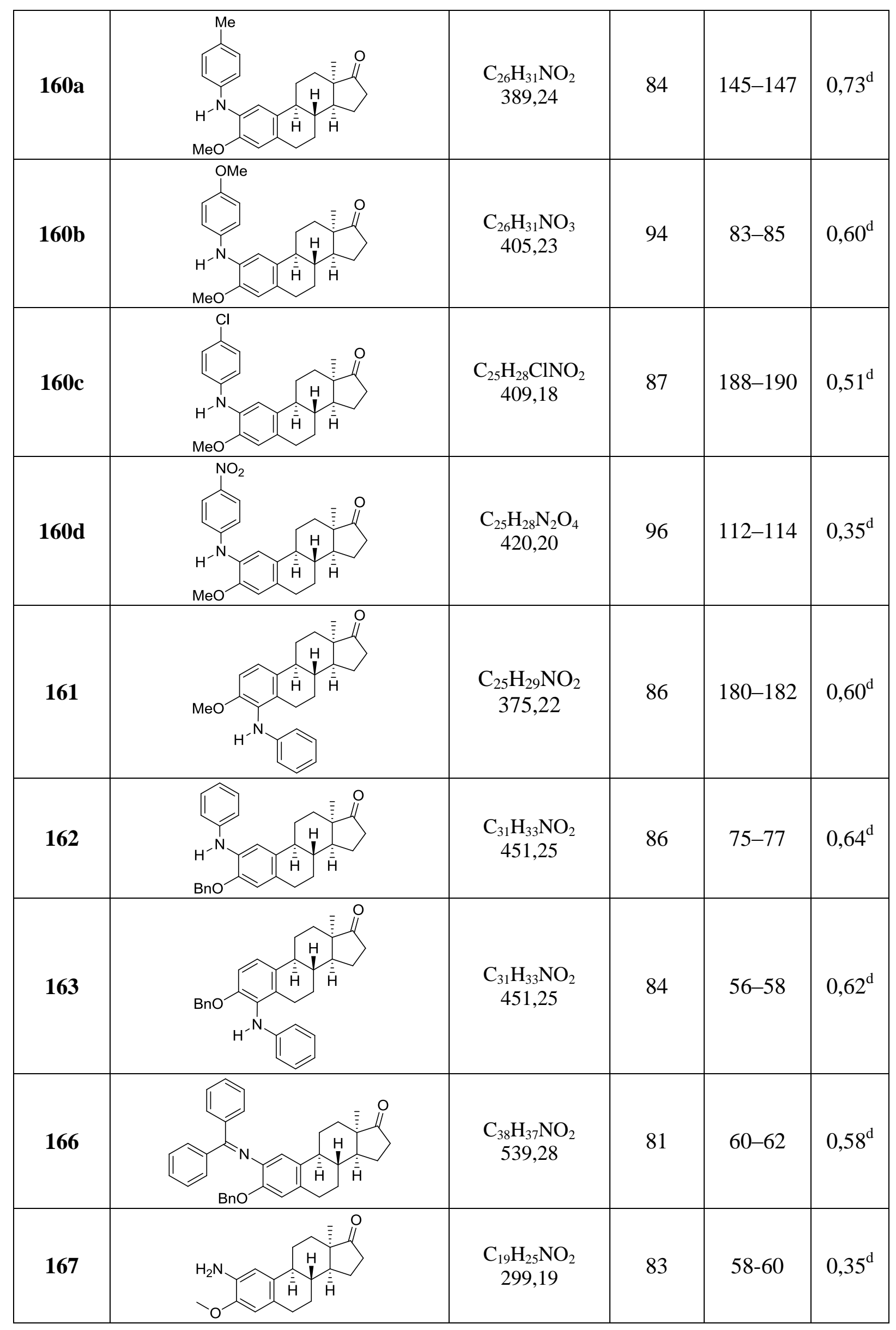




\begin{tabular}{|l|l|l|l|l|l|}
\hline 169 & & & $C_{18} \mathrm{H}_{23} \mathrm{NO}_{2}$ \\
285,17 & 95 & $208-210$ & $0,55^{\mathrm{d}}$ \\
\hline
\end{tabular}

VIII. A vegyületek NMR adatai

$157{ }^{1} \mathrm{H}$ NMR (DMSO-d 6 ) $\delta$ ppm :0,96(s, 3H, 18- $\left.\mathrm{H}_{3}\right) ; 2,74\left(\mathrm{~s}, 2 \mathrm{H}, 6-\mathrm{H}_{2}\right) ; 3,73\left(\mathrm{~s}, 3 \mathrm{H}, 3-\mathrm{OCH}_{3}\right)$; 6,67(s; 1H, 4-H); 6,69(t, 1H, 4'-H); 6,88(d, 2H, 2'-H, 6'-H); 7,08(s, 1H, 1-H); 7,12(d, 2H, 3'$\left.\mathrm{H}, 5^{\prime}-\mathrm{H}\right) ; 7,14(\mathrm{~s}, 1 \mathrm{H}, \mathrm{NH}) ;{ }^{13} \mathrm{C}$ NMR $\left(\mathrm{DMSO}_{-} \mathrm{d}_{6}\right) \delta \mathrm{ppm}: 20,4 ; 24,5(\mathrm{C}-18) ; 27,8 ; 28,2 ; 29,4$; 31,$6 ; 32,8 ; 40,7 ; 40,8 ; 48,4 ; 49,4(\mathrm{C}-13) ; 55,3\left(3-\mathrm{OCH}_{3}\right) ; 111,5(\mathrm{C}-4) ; 115,4(2 \mathrm{C}: \mathrm{C}-2$ ', C-6'); 116,6(C-1) 118,3(C-4'); 128,8(2C: C-3', C-5'); 129,0(C-2); 129,9 és 131,0(C-5, C-10); 144,8(C-1') 148,6(C-3); 220,6(C-17); MS m/z (\%): $376\left(100,[\mathrm{M}+\mathrm{H}]^{+}\right)$.

158a ${ }^{1} \mathrm{H}$ NMR $\left(\mathrm{DMSO}_{6}\right) \delta \mathrm{ppm}: 0,95\left(\mathrm{~s}, 3 \mathrm{H}, 18-\mathrm{H}_{3}\right) ; 2$, 15(s, 3H, 2'-Me); 2,75(m, 2H, 6$\left.\mathrm{H}_{2}\right) ; 3,75\left(\mathrm{~s}, 3 \mathrm{H}, 3-\mathrm{OCH}_{3}\right) ; 6,30(\mathrm{~s} ; 1 \mathrm{H}, \mathrm{NH}) ; 6,66(\mathrm{~s}, 1 \mathrm{H}, 4-\mathrm{H}) ; 6,76(\mathrm{~s}, 1 \mathrm{H}, 1-\mathrm{H}) ; 6,80(\mathrm{t}, 1 \mathrm{H}$, $J=7,5 \mathrm{~Hz}, 5 '-\mathrm{H}) ; 6,82(\mathrm{~d}, 1 \mathrm{H}, J=7,3 \mathrm{~Hz}, 3$ 6'-H); 7,04(t, 1H, J=7,5 Hz, 4'-H); 7,13(d, 1H,

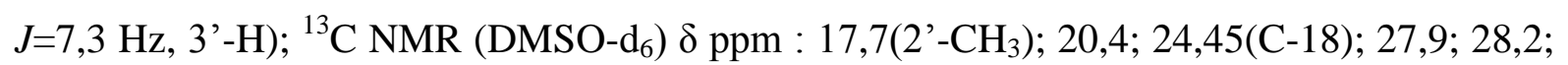
29,3; 30,3; 31,5; 32,8; 40,8; 48,4; 49,4(C-13); 55,4( $\left.\mathrm{OCH}_{3}\right)$; 111,2(C-4); 115,3(C-1); 117,3(C6’); 120,3(C-5'); 126,3(C-4') 127,2(C-1'); 129,0(C-2); 130,3(C-3'); 130,4(C-10); 131,0(C5); 142,3(C-2'); 147,8(C-3); 220,6(C-17). MS m/z (\%): $390\left(100,[\mathrm{M}+\mathrm{H}]^{+}\right)$.

158b ${ }^{1} \mathrm{H}$ NMR (DMSO-d $\left.{ }_{6}\right) \delta$ ppm :0,96(s, 3H, 18- $\left.\mathrm{H}_{3}\right) ; 2,73\left(\mathrm{~m}, 2 \mathrm{H}, 6-\mathrm{H}_{2}\right) ; 3,76(\mathrm{~s}, 3 \mathrm{H}, 3-$ $\left.\mathrm{OCH}_{3}\right) ; 3,82\left(\mathrm{~s}, 3 \mathrm{H}, 3^{\prime}-\mathrm{OCH}_{3}\right) ; 6,31(\mathrm{~s} ; 1 \mathrm{H}, \mathrm{NH}) ; 6,67(\mathrm{~s}, 1 \mathrm{H}, 4-\mathrm{H}) ; 6,77\left(\mathrm{t}, 1 \mathrm{H}, J=7,2 \mathrm{~Hz}, 4^{\prime}-\right.$ H); 6,83(t, 1H, J=7,2 Hz, 5'-H); 6,95(d, 1H, J=7,9 Hz, 3'-H); 7,02(d, 1H, J=7,9 Hz, 6'-H); 7,11(s, 1H, 1-H); ${ }^{13} \mathrm{C}$ NMR (DMSO-d 6 ) $\delta$ ppm : 20,4; 24,5(C-18); 27,8; 28,2; 29,4; 31,6; 32,$8 ; 40,8 ; 40,9 ; 48,4 ; 49,4 ; 55,5\left(2 \mathrm{C}: 3-\mathrm{OCH}_{3}\right.$ és 4'- $\left.-\mathrm{OCH}_{3}\right) ; 110,7(\mathrm{C}-3$ ') $)$ 111,1(C-4); 113,3(C-6’); 114,5(C-1); 119,1(C-4'); 120,6(C-5'); 128,8(C-10); 129,2(C-2); 131,0(C-5); 132,7(C-1'); 147,3(C-3); 147,8(C-2'); 220,7(C-17). MS m/z (\%): $406\left(100,[\mathrm{M}+\mathrm{H}]^{+}\right)$.

158c ${ }^{1} \mathrm{H}$ NMR $\left(\right.$ DMSO-d $\left._{6}\right) \delta$ ppm :0,96(s, 3H, 18- $\left.\mathrm{H}_{3}\right) ; 2,77\left(\mathrm{~m}, 2 \mathrm{H}, 6-\mathrm{H}_{2}\right) ; 3,73(\mathrm{~s}, 3 \mathrm{H}, 3-$ $\left.\mathrm{OCH}_{3}\right) ; 6,64(\mathrm{~s} ; 1 \mathrm{H}, 4-\mathrm{H}) ; 6,73(\mathrm{~s} ; 1 \mathrm{H}, \mathrm{NH}) ; 6,74$ és 7,12(2t, 2x1H, J=7,7 Hz, 4'-H és 5'-H); $6,85$ és 7,35(2d, 2x1H, $J=7,9 \mathrm{~Hz}, 3$ '-H és 6 '-H); 7,06(s; $1 \mathrm{H}, 1-\mathrm{H}) ;{ }^{13} \mathrm{C} \mathrm{NMR}\left(\mathrm{CDCl}_{3}\right) \delta \mathrm{ppm}$ : 20,1; 25,1(C-18); 28,4; 28,5; 30,1; 32,1;33,5; 41,6; 41,6; 49,2; 50,2(C-13); 55,7(3-OCH $)$; 111,2 és 115,2 és 116,4 és $119,9\left(C_{-1}\right.$ és C-4 és C-4' és C-6’); 121,9(C-10); 127,4(C-5’); 
128,6(C-5); 129,6(C-3’); 130,6 és 131,6(C-2 és C-2'); 140,5(C-1'); 148,4(C-3); 221,7(C-17). MS m/z (\%): 394 (100); $410\left(5,[\mathrm{M}+\mathrm{H}]^{+}\right)$.

158d ${ }^{1} \mathrm{H}$ NMR $\left(\mathrm{CDCl}_{3}\right) \delta \mathrm{ppm}: 1,06\left(\mathrm{~s}, 3 \mathrm{H}, 18-\mathrm{H}_{3}\right) ; 2,86\left(\mathrm{~m}, 2 \mathrm{H}, 6-\mathrm{H}_{2}\right) ; 3,80\left(\mathrm{~s}, 3 \mathrm{H}, 3-\mathrm{OCH}_{3}\right)$; 6,67(s; 1H, 4-H); 6,72(t, 1H, $\left.J=7,1 \mathrm{~Hz}, 4^{\prime}-\mathrm{H}\right) ; 7,11(\mathrm{~d}, 1 \mathrm{H}, J=7,9 \mathrm{~Hz}, 6$ '-H); 7,34(t, 1H, $J=$ $\left.7,1 \mathrm{~Hz}, 5^{\prime}-\mathrm{H}\right) ; 8,18\left(\mathrm{~d}, 1 \mathrm{H}, J=7,9 \mathrm{~Hz}, 3\right.$ '-H); 7,25(s; 1H, 1-H); 9,35(s; 1H, NH); ${ }^{13} \mathrm{C}$ NMR $\left(\mathrm{CDCl}_{3}\right) \delta$ ppm : 21,0; 25,0(C-18); 28,3; 28,4; 30,2; 32,0; 33,4; 41,4; 41,4; 49,2; 50,2(C-13); 55,7(3- $\left.\mathrm{OCH}_{3}\right)$; 111,7(C-4); 116,0(C-6'); 117,0(C-4'); 122,1(C-1); 125,2(C-2); 126,6(C-5'); 132,0(C-10); 133,3(C-2'); 134,8(C-5); 135,5(C-5'); 143,2(C-1'); 151,0(C-3); 221,5(C-17). MS m/z (\%): $421\left(100,[\mathrm{M}+\mathrm{H}]^{+}\right)$.

159a ${ }^{1} \mathrm{H}$ NMR (DMSO-d $\left.\mathrm{d}_{6}\right) \delta \mathrm{ppm}: 0,96\left(\mathrm{~s}, 3 \mathrm{H}, 18-\mathrm{H}_{3}\right) ; 2,18\left(\mathrm{~s}, 3 \mathrm{H}, 3{ }^{\prime}-\mathrm{CH}_{3}\right) ; 2,74(\mathrm{~m}, 2 \mathrm{H}, 6-$ $\left.\mathrm{H}_{2}\right) ; 3,73\left(\mathrm{~s}, 3 \mathrm{H}, 3-\mathrm{OCH}_{3}\right) ; 6,51\left(\mathrm{~d}, 1 \mathrm{H}, J=7,4 \mathrm{~Hz}, 4^{\prime}-\mathrm{H}\right) ; 6,67(\mathrm{~s}, 1 \mathrm{H}, 4-\mathrm{H}) ; 6,69(\mathrm{~d}, 1 \mathrm{H}, J=7,4$ $\mathrm{Hz}, 6$ '-H); 6,68(s, 1H, 2'-H); 7,01(t, 1H, J=7,7 Hz, 5'-H); 7,04(s, 1H, NH); 7,07(s; 1H, 1-H); ${ }^{13} \mathrm{C}$ NMR (DMSO-d 6 ) $\delta$ ppm : 20,4; 21,2(3'-CH ); 24,5(C-18); 27,8; 28,2; 29,4; 31,6; 32,8; 40,$80 ; \quad 40,8048,4 ; \quad 49,4(\mathrm{C}-13) ; \quad 55,3\left(3-\mathrm{OCH}_{3}\right) ; \quad 111,5(\mathrm{C}-4) ; 112,5(\mathrm{C}-6$ '); 116,2(C-2'); 116,9(C-1); 119,1(C-4'); és 128,6(C-5'); 129,1(C-10); 129,9(C-5); 131,0(C-2); 137,8(C-3'); 144,8(C-1'); 148,6(C-3); 220,6(C-17). MS m/z (\%): $390\left(100,[\mathrm{M}+\mathrm{H}]^{+}\right)$.

159b ${ }^{1} \mathrm{H}$ NMR (DMSO-d $\left.{ }_{6}\right) \delta$ ppm : 0,96(s, 3H, 18- $\left.\mathrm{H}_{3}\right) ; 2,74\left(\mathrm{~m}, 2 \mathrm{H}, 6-\mathrm{H}_{2}\right) ; 3,65(\mathrm{~s}, 3 \mathrm{H}, 3-$ $\left.\mathrm{OCH}_{3}\right) ; 3,73\left(\mathrm{~s}, 3 \mathrm{H}, 3^{\prime}-\mathrm{OCH}_{3}\right) ; 6,27\left(\mathrm{~m}, 1-\mathrm{H}, 4^{\prime}-\mathrm{H}\right) ; 6,47\left(\mathrm{~m}, 2 \mathrm{H}, 2^{\prime}-\mathrm{H}, 6\right.$ '-H); 6,50(s, 1H, 4'$\mathrm{H}) ; 6,67(\mathrm{~s}, 1 \mathrm{H}, 4-\mathrm{H}) ; 7,03\left(\mathrm{t}, 1 \mathrm{H}, J=7,9 \mathrm{~Hz}, 5^{\prime}-\mathrm{H}\right) ; 7,11(\mathrm{~s}, 1 \mathrm{H}, 1-\mathrm{H}) ; 7,17(\mathrm{~s} ; 1 \mathrm{H}, \mathrm{NH}) ;{ }^{13} \mathrm{C}$ NMR (DMSO-d d $_{6} \delta$ ppm : 20,4; 24,5(C-18); 27,8; 28,3; 29,4; 31,6; 32,8; 40,7; 40,8; 48,4; 49,4(C-13); 54,6 és 55,3(3- $\mathrm{OCH}_{3}$ és 3'- $\left.\mathrm{OCH}_{3}\right)$; 100,8(C-2'); 103,8(C-4'); 107,9(C-6'); $111,5(\mathrm{C}-4) ; 117,1(\mathrm{C}-1) ; 128,8(\mathrm{C}-2) ; 129,5\left(\mathrm{C}-5^{\prime}\right) ; 130,1(\mathrm{C}-10) ; 131,0(\mathrm{C}-5) ; 146,2\left(\mathrm{C}-1^{\prime}\right)$; 148,6(C-3); 160,0(C-3'); 220,7(C-17). MS m/z (\%): $406\left(100,[\mathrm{M}+\mathrm{H}]^{+}\right)$.

159c ${ }^{1} \mathrm{H}$ NMR $\left(\right.$ DMSO-d $\left._{6}\right) \delta$ ppm :0,96(s, 3H, 18- $\left.\mathrm{H}_{3}\right) ; 2,76\left(\mathrm{~m}, 2 \mathrm{H}, 6-\mathrm{H}_{2}\right) ; 3,72(\mathrm{~s}, 3 \mathrm{H}, 3-$ $\left.\mathrm{OCH}_{3}\right) ; 6,65$ és $6,74\left(2 \mathrm{~d}, 2 \mathrm{x} 1 \mathrm{H}, J=6,8 \mathrm{~Hz}, 4^{\prime}-\mathrm{H}, 6\right.$ ' $\left.-\mathrm{H}\right) ; 6,71(\mathrm{~s} ; 1 \mathrm{H}, 4-\mathrm{H}) ; 6,77\left(\mathrm{~s} ; 1 \mathrm{H}, 2^{\prime}-\mathrm{H}\right)$; 7,07(s, 1H, 1-H); 7,11(t, 1H, $\left.J=8,0 \mathrm{~Hz}, 5^{\prime}-\mathrm{H}\right) ; 7,55(\mathrm{~s}, 1 \mathrm{H}, \mathrm{NH}){ }^{13} \mathrm{C}$ NMR (DMSO-d 6 ) $\delta$ ppm: 20,$4 ; 24,4(\mathrm{C}-18) ; 27,7 ; 28,2 ; 29,4 ; 31,6 ; 32,8 ; 40,7 ; 40,7 ; 48,4(\mathrm{C}-13) ; 55,3\left(3-\mathrm{OCH}_{3}\right)$; 111,8(C-4); 112,7(C-6'); 113,7(C-2'); 117,0(C-1); 119,4(C-4'); 127,5(C-2); 130,2(C-5'); 131,3(C-10); 131,9(C-5); 133,3(C-3') 147,2(C-1'); 149,7(C-3); 220,6(C-17). MS m/z (\%): $493(100) ; 451\left(67,[\mathrm{M}+\mathrm{MeCN}+\mathrm{H}]^{+}\right) ; 410\left(40,[\mathrm{M}+\mathrm{H}]^{+}\right)$. 
159d ${ }^{1} \mathrm{H} \mathrm{NMR}\left(\mathrm{CDCl}_{3}\right) \delta \mathrm{ppm}: 1,06\left(\mathrm{~s}, 3 \mathrm{H}, 18-\mathrm{H}_{3}\right) ; 2,83\left(\mathrm{~m}, 2 \mathrm{H}, 6-\mathrm{H}_{2}\right) ; 3,82\left(\mathrm{~s}, 3 \mathrm{H}, 3-\mathrm{OCH}_{3}\right)$; 6,62(s; 1H, 4-H) 7,22(s; 1H, 1-H); 7,30 és 7,60(2d, 2x1H, $J=7,8 \mathrm{~Hz}, 4$ '-H és 6'-H); 7,34(t, $\left.1 \mathrm{H}, J=8,1 \mathrm{~Hz}, 5{ }^{\prime}-\mathrm{H}\right) ; 7,78(\mathrm{~s} ; 1 \mathrm{H}, \mathrm{NH}) ;{ }^{13} \mathrm{C} \mathrm{NMR}\left(\mathrm{CDCl}_{3}\right) \delta \mathrm{ppm}: 21,0 ; 25,1(\mathrm{C}-18) ; 28,3$; 28,$5 ; 30,1 ; 32,0 ; 33,4 ; 41,5 ; 41,6 ; 49,2 ; 50,2(\mathrm{C}-13) ; 55,6\left(3-\mathrm{OCH}_{3}\right) ; 110,3$ és 111,3 és 114,2 és 116,8 és 121,3(C-1 és C-4 és C-2' és C-4' és C-6'); 127,9(C-10); 129,8(C-5'); 131,6(C-5); 131,9(C-2); 145,5(C-1'); 148,4(C-3); 149,3(C-3’); 221,6(C-17). MS m/z (\%): 421 (10, [M + $\left.\mathrm{H}]^{+}\right) ; 453\left(100,[\mathrm{M}+\mathrm{MeOH}+\mathrm{H}]^{+}\right)$.

160a ${ }^{1} \mathrm{H}$ NMR (DMSO-d $\left.{ }_{6}\right) \delta$ ppm :0,95(s, 3H, 18- $\left.\mathrm{H}_{3}\right) ; 2,18\left(\mathrm{~s}, 3 \mathrm{H}, 4{ }^{\prime}-\mathrm{CH}_{3}\right) ; 2,72(\mathrm{~m}, 2 \mathrm{H}, 6-$ $\left.\mathrm{H}_{2}\right) ; 3,73\left(\mathrm{~s}, 3 \mathrm{H}, 3-\mathrm{OCH}_{3}\right) ; 6,63(\mathrm{~s}, 1 \mathrm{H}, 4-\mathrm{H}) ; 6,84\left(\mathrm{~d}, 2 \mathrm{H}, J=8,9 \mathrm{~Hz}, 2^{\prime}-\mathrm{H}, 6{ }^{\prime}-\mathrm{H}\right) ; 6,95(\mathrm{~s}, 1 \mathrm{H}$, $\mathrm{NH}) ; 6,97\left(\mathrm{~d}, 2 \mathrm{H}, J=8,9 \mathrm{~Hz}, 3{ }^{\prime}-\mathrm{H}, 5^{\prime}-\mathrm{H}\right) ; 6,95(\mathrm{~s}, 1 \mathrm{H}, 1-\mathrm{H}) ; 7,03(\mathrm{~s}, 1 \mathrm{H}, 1-\mathrm{H}) ;{ }^{13} \mathrm{C}$ NMR $\left(\right.$ DMSO-d $\left._{6}\right) \delta$ ppm : 20,1(4'-CH 3 ); 20,4; 24,5(C-18); 27,9; 28,2; 29,3; 31,5; 32,8; 40,8; 40,9; 48,4; 49,4(C-13); 55,3( $\left(\mathrm{OCH}_{3}\right) ; 111,3(\mathrm{C}-4) ; 114,8(\mathrm{C}-1) ; 116,4(2 \mathrm{C}: \mathrm{C}-2$ ', C-6'); 129,2(2C: C3', C-5'); 127,4(C-1'); 128,9(C-10); 129,8(C-2); 131,0(C-5); 141,8(C-4'); 147,8(C-3); 220,6(C-17). MS m/z (\%): $390\left(100,[\mathrm{M}+\mathrm{H}]^{+}\right)$.

160b ${ }^{1} \mathrm{H}$ NMR (DMSO-d $\left.{ }_{6}\right) \delta \mathrm{ppm}: 0,95\left(\mathrm{~s}, 3 \mathrm{H}, 18-\mathrm{H}_{3}\right) ; 2,70\left(\mathrm{~m}, 2 \mathrm{H}, 6-\mathrm{H}_{2}\right) ; 3,68(\mathrm{~s}, 3 \mathrm{H}, 3-$ $\left.\mathrm{OCH}_{3}\right) ; 3,74(\mathrm{~s}, 3 \mathrm{H}, 3$ '-OCH 3$) ; 6,61(\mathrm{~s}, 1 \mathrm{H}, 4-\mathrm{H}) ; 6,79(\mathrm{~s}, 1 \mathrm{H}, \mathrm{NH}) 6,80 \mathrm{~d}, 2 \mathrm{H}, J=8,8 \mathrm{~Hz}, 3$ '$\left.\mathrm{H}, 5^{\prime}-\mathrm{H}\right) ; 6,92(\mathrm{~s}, 1 \mathrm{H}, 1-\mathrm{H}) ; 6,93\left(\mathrm{~d}, 2 \mathrm{H}, J=8,8 \mathrm{~Hz}, 2^{\prime}-\mathrm{H}, 6{ }^{\prime}-\mathrm{H}\right) ;{ }^{13} \mathrm{C} \mathrm{NMR}\left(\mathrm{CDCl}_{3}\right) \delta \mathrm{ppm}:$ 20,$4 ; 24,5(\mathrm{C}-18) ; 27,9 ; 28,3 ; 29,3 ; 31,5 ; 32,8 ; 40,8 ; 40,9 ; 48,4 ; 49,4 ; 55,1$ és 55,3(3-OCH 3 és 4'- $\left.\mathrm{OCH}_{3}\right) ; 111,2(\mathrm{C}-4) ; 112,7(\mathrm{C}-1) ; 114,3(2 \mathrm{C}: \mathrm{C}-3$ ', C-5'); 119,1(2C: C-2', C-6'); 127,7(C1'); 130,9(C-10); 131,0(C-5); 137,1(C-2); 147,0(C-3); 153,0(C-4'); 220,7(C-17). MS m/z (\%): $406\left(100,[\mathrm{M}+\mathrm{H}]^{+}\right)$.

160c ${ }^{1} \mathrm{H}$ NMR $\left(\right.$ DMSO-d $\left._{6}\right) \delta$ ppm :0,96(s, 3H, 18- $\left.\mathrm{H}_{3}\right) ; 2,76\left(\mathrm{~m}, 2 \mathrm{H}, 6-\mathrm{H}_{2}\right) ; 3,73(\mathrm{~s}, 3 \mathrm{H}, 3-$ OMe); 6,69(s; 1H, 4-H); 6,83(d, 2H, $\left.J=8,7 \mathrm{~Hz}, 2^{\prime}-\mathrm{H}, 6^{\prime}-\mathrm{H}\right)$; és 7,14(d, 2H, $J=8,7 \mathrm{~Hz}, 3$ '-H, $\left.5^{\prime}-\mathrm{H}\right) ; 7,06(\mathrm{~s} ; 1 \mathrm{H}, 1-\mathrm{H}) ; 7,41(\mathrm{~s} ; 1 \mathrm{H}, \mathrm{NH}) ;{ }^{13} \mathrm{C}$ NMR (DMSO-d 6$) \delta \mathrm{ppm}: 20,4 ; 24,5(\mathrm{C}-18)$; 27,8; 28,2; 29,4; 31,6; 32,8; 40,7; 40,8; 48,4; 49,4, 55,3( $\left.\mathrm{OCH}_{3}\right) ; 111,7(\mathrm{C}-4) ; 116,3(2 \mathrm{C}: \mathrm{C}-2$ ', C-6'); 117,8(C-1); 121,0(C-4'); 128,3(C-2); 128,5(2C: C-3', C-5'); 131,0(C-10); 131,2(C-5); 144,2(C-1'); 149,1(C-3); 220,6(C-17). MS m/z (\%): $451\left(100,[\mathrm{M}+\mathrm{MeCN}+\mathrm{H}]^{+}\right) ; 410$ (51, $\left.[\mathrm{M}+\mathrm{H}]^{+}\right)$.

160d ${ }^{1} \mathrm{H}$ NMR (DMSO-d 6 ) $\delta$ ppm :0,96(s, 3H, 18- $\left.\mathrm{H}_{3}\right) ; 2,80\left(\mathrm{~m}, 2 \mathrm{H}, 6-\mathrm{H}_{2}\right) ; 3,72(\mathrm{~s}, 3 \mathrm{H}, 3-$ $\left.\mathrm{OCH}_{3}\right) ; 6,71\left(\mathrm{~d}, 2 \mathrm{H}, J=9,2 \mathrm{~Hz}, 2^{\prime}-\mathrm{H}, 6^{\prime}-\mathrm{H}\right) ; 6,80(\mathrm{~s} ; 1 \mathrm{H}, 4-\mathrm{H}) ; 7,11(\mathrm{~s} ; 1 \mathrm{H}, 1-\mathrm{H}) ; 8,00(\mathrm{~d}, 2 \mathrm{H}, J$ $\left.=9,2 \mathrm{~Hz}, 3^{\prime}-\mathrm{H}, 5^{\prime}-\mathrm{H}\right) ; 8,72(\mathrm{~s}, 1 \mathrm{H}, \mathrm{NH}) ;{ }^{13} \mathrm{C}$ NMR $\left(\mathrm{DMSO}^{-} \mathrm{d}_{6}\right) \delta \mathrm{ppm}: 20,4 ; 24,5(\mathrm{C}-18)$; 27,$7 ; 28,0 ; 29,5 ; 31,5 ; 32,8 ; 40,6 ; 40,7 ; 48,4 ; 49,4(\mathrm{C}-13) ; 55,3\left(\mathrm{OCH}_{3}\right) ; 112,1(\mathrm{C}-4) ; 112,4(2 \mathrm{C}$ : 
C-2' és C-6'); 122,5(C-1); 125,2(C-2); 125,9(2C: C-3' és C-5'); 131,7(C-10); 134,9(C-5); 136,8(C-4'); 151,0(C-1'); 152,6(C-3); 220,6(C-17). MS m/z (\%): $421\left(7,[\mathrm{M}+\mathrm{H}]^{+}\right) ; 493$ $\left(100,[\mathrm{M}+\mathrm{MeCN}+\mathrm{MeOH}+\mathrm{H}]^{+}\right)$.

$161 \mathrm{Mp},:{ }^{1} \mathrm{H}$ NMR $\left(\mathrm{CDCl}_{3}\right) \delta \mathrm{ppm}: 1,06\left(\mathrm{~s}, 3 \mathrm{H}, 18-\mathrm{H}_{3}\right) ; 2,47$ és 2,81(2xm, 2H, 6- $\left.\mathrm{H}_{2}\right) ; 3,77(\mathrm{~s}$, 3H, 3-OMe); 6,65(d, 2H, J=8,3 Hz, 2'-H és 6'-H); 6,79(d, 1H, $J=8,6 \mathrm{~Hz}, 2-\mathrm{H}) ; 6,83(\mathrm{t}, 1 \mathrm{H}$, $\left.J=7,9 \mathrm{~Hz}, 4^{\prime}-\mathrm{H}\right) ; 7,12(\mathrm{~d}, 1 \mathrm{H}, J=8,6 \mathrm{~Hz}, 1-\mathrm{H}) ; 7,19$ (t, $2 \mathrm{H}, J=7,4 \mathrm{~Hz}, 3$ '-H és 5 '-H); ${ }^{13} \mathrm{C}$ NMR $\left(\mathrm{CDCl}_{3}\right) \delta$ ppm: 20,9; 25,0(C-18); 26,1; 27,9; 28,6; 32,2; 33,4; 41,1; 41,8; 49,4; 50,2(C-13); 55,8( $\left(\mathrm{OCH}_{3}\right) ; 108,7(\mathrm{C}-2) ; 115,6\left(2 \mathrm{C}: \mathrm{C}^{\prime}{ }^{\prime}\right.$, C-6'); 119,6(C-4'); 123,0(C-1); 127,8(C-4); 129,0(2C: C-3', C-5'); 133,2(C-10); 134,5(C-5); 145,5(C-1'); 151,9(C-3); 221,8(C-17). MS $\mathrm{m} / \mathrm{z}(\%): 376\left(100,[\mathrm{M}+\mathrm{H}]^{+}\right)$.

$162{ }^{1} \mathrm{H}$ NMR (DMSO-d 6$) \delta$ ppm :1,02(s, 3H, 18- $\left.\mathrm{H}_{3}\right) ; 2,74\left(\mathrm{~m}, 2 \mathrm{H}, 6-\mathrm{H}_{2}\right) ; 5,02(\mathrm{~s}, 2 \mathrm{H}, 3-$ $\left.\mathrm{OCH}_{2}\right) ; 6,71\left(\mathrm{t}, J=7,2 \mathrm{~Hz}, 1 \mathrm{H}, 4^{\prime}-\mathrm{H}\right) ; 6,76(\mathrm{~s}, 1 \mathrm{H}, 4-\mathrm{H}) ; 6,88\left(\mathrm{~d}, J=7,7 \mathrm{~Hz}, 2 \mathrm{H}, 2^{\prime}-\mathrm{H}, 6^{\prime}-\mathrm{H}\right)$; 7,10(s, 1H, 1-H); 7,13-7,16(átfedő multipletek, 2H, 3'-H, 5'-H, NH); 7,26(m, 1H, 4'-H); 7,31(t, $J=7,2 \mathrm{~Hz}, 2 \mathrm{H}, 2$ "-H, 6"-H); 7,36(d, J = 7,2 Hz, 2H, 3"-H, 5"-H); ${ }^{13} \mathrm{C}$ NMR (DMSO$\left.\mathrm{d}_{6}\right) \delta$ ppm: 20,4; 24,5(C-18); 27,8; 29,3; 31,5; 32,8; 40,7; 40,8; 48,4; 49,4(C-13); 69,4( $\left(\mathrm{OCH}_{2}\right) ; 113,2(\mathrm{C}-4) ; 115,5\left(2 \mathrm{C}: \mathrm{C}^{2} 2^{\prime}, \mathrm{C}^{2} 6^{\prime}\right) ; 117,6(\mathrm{C}-1)$; 118,3(C-4'); 127,1(2C: C-3”, C5"); 127,4(C-4”); 128,1(2C: C-2”, C-6”); 128,7(2C: C-3', C-5'); 129,4 és 130,3(C-2 és C10); 131,5(C-5); 137,3(C-1”); 145,0(C-1'); 147,8(C-3); 220,6(C-17). MS m/z (\%): 452 (100, $\left.[\mathrm{M}+\mathrm{H}]^{+}\right)$.

$163{ }^{1} \mathrm{H}$ NMR (DMSO-d 6 ) $\delta$ ppm :0,97(s, 3H, 18- $\left.\mathrm{H}_{3}\right) ; 2,30$ és 2,75(2xm, 2H, 6- $\mathrm{H}_{2}$ ); 5,02(s, $\left.2 \mathrm{H}, 3-\mathrm{OCH}_{2}\right)$; ); 6,47(d, 2H, $J=7,7 \mathrm{~Hz}, 2^{\prime}-\mathrm{H}, 6$ '- $\left.-\mathrm{H}\right)$; 6,58(d, $\left.1 \mathrm{H}, J=7,2 \mathrm{~Hz}, 4^{\prime}-\mathrm{H}\right) ; 6,58(\mathrm{~d}$, $1 \mathrm{H}, J=8,6 \mathrm{~Hz}, 2-\mathrm{H}) ; 6,98(\mathrm{~s}, 1 \mathrm{H}, \mathrm{NH}) ; 7,05\left(\mathrm{t}, 2 \mathrm{H}, J=7,7 \mathrm{~Hz}, 3^{\prime}-\mathrm{H}, 5^{\prime}-\mathrm{H}\right) ; 7,08(\mathrm{~d}, 1 \mathrm{H}, J=$ 8,6 Hz, 1-H); 7,19-7,24(átfedő multipletek, 5H, 2"-H, 3"'-H, 5"-H, 6"-H); ${ }^{13} \mathrm{C}$ NMR (DMSO$\left.\mathrm{d}_{6}\right) \delta$ ppm: 20,4; 24,4(C-18);25,5; 27,4; 28,1;31,6;32,7;40,3;41,1;48,5;49,3(C-13); 69,2( $\left(\mathrm{OCH}_{2}\right) ; 110,9(\mathrm{C}-2)$; 113,1(2C: C-2', C-6'); 116,5(C-4'); 123,0(C-1); 126,9(2C: C-2”, C6"); 127,3(C-4”); 127,8(C-4); 128,0(2C: C-3", C-5”); 128,5(2C: C-3', C-5'); 132,8(C-10); 135,5(C-5); 137,3(C-1”); 147,0(C-1'); 151,8(C-3); 220,6(C-17). MS m/z (\%): 452 (100, [M + $\mathrm{H}]^{+}$.

$166{ }^{1} \mathrm{H}$ NMR (DMSO-d 6 ) $\delta$ ppm :0,93(s, 3H, 18- $\left.\mathrm{H}_{3}\right) ; 2,62\left(\mathrm{~m}, 2 \mathrm{H}, 6-\mathrm{H}_{2}\right) ; 4,97(\mathrm{~s}, 2 \mathrm{H}, 3-$ $\left.\mathrm{OCH}_{2}\right) ; 6,45(\mathrm{~s}, 1 \mathrm{H}, 1-\mathrm{H}) ; 6,58(\mathrm{~s}, 1 \mathrm{H}, 4-\mathrm{H}) ; 7,07-7,62$ (átfedő multipletek, 15H, 2'-H, 3'-H, 4'-H, 5'-H, ); 7,26(m, 1H, 4"-H); 7,31(t, $J=7,2 \mathrm{~Hz}, 2 \mathrm{H}, 2$ '”-H, 6"-H); 7,36(d, $J=7,2 \mathrm{~Hz}, 2 \mathrm{H}$, 3 '-H, 5"-H); ${ }^{13} \mathrm{C}$ NMR (DMSO-d 6 ) $\delta$ ppm: 20,8; 24,9(C-18); 28,1; 28,5; 29,8; 32,1; 33,3; 
41,$3 ; 48,8 ; 49,9(\mathrm{C}-13) ; \quad 69,8\left(\mathrm{OCH}_{2}\right) ; 113,7(\mathrm{C}-4) ; 118,7(\mathrm{C}-1) ; 127,5(2 \mathrm{C})$ és 128,0 és $128,4(2 \mathrm{C})$ és $128,6(2 \mathrm{C})$ és $128,8(3 \mathrm{C})$ és 128,9 és 129,1(2C) és 130,1 és 131,2(C-2', C-3', C-

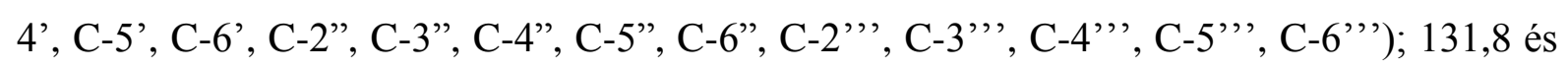
132,2 és 137,0 és 138,1 és 139,1 és 139,4(C-2, C-5, C-10, C-1', C-1", C-1"'’); 146,5(C-3); 168,4(C=N); 221,2(C-17). MS m/z (\%): $540\left(100,[\mathrm{M}+\mathrm{H}]^{+}\right)$.

$167{ }^{1} \mathrm{H}$ NMR (DMSO-d $\left.{ }_{6}\right) \delta$ ppm :0,96(s, 3H, 18- $\left.\mathrm{H}_{3}\right) ; 2,62\left(\mathrm{~s}, 2 \mathrm{H}, 6-\mathrm{H}_{2}\right) ; 3,68$ (s, 3H, 3-O $\left.\mathrm{CH}_{3}\right) ; 4,37\left(\mathrm{~s}, 2 \mathrm{H}, \mathrm{NH}_{2}\right) 6,43(\mathrm{~s} ; 1 \mathrm{H}, 4-\mathrm{H}) ; 6,54(\mathrm{~s}, 1 \mathrm{H}, 1-\mathrm{H}) ;{ }^{13} \mathrm{C}$ NMR (DMSO-d 6 ) $\delta \mathrm{ppm}$ : 20,$4 ; 24,5(\mathrm{C}-18) ; 28,1 ; 28,3 ; 29,2 ; 31,7 ; 32,8 ; 40,9 ; 41,0 ; 48,5 ; 49,4 ; 55,1\left(3-\mathrm{OCH}_{3}\right) ; 110.5$; 111,$4 ; 124,0 ; 131,1 ; 134,9 ; 144,7 ; 220,7(\mathrm{C}-17)$.

$169{ }^{1} \mathrm{H}$ NMR $\left(\right.$ DMSO-d $\left._{6}\right) \delta$ ppm :0,95(s, 3H, 18- $\left.\mathrm{H}_{3}\right) ; 2,55\left(\mathrm{~m}, 2 \mathrm{H}, 6-\mathrm{H}_{2}\right) ; 4,20($ broad s, $2 \mathrm{H}, 2-$ $\left.\mathrm{NH}_{2}\right) ; 6,29(\mathrm{~s} ; 1 \mathrm{H}, 4-\mathrm{H}) ; 6,49(\mathrm{~s}, 1 \mathrm{H}, 1-\mathrm{H}) ; 8,66(\mathrm{~s}, 1 \mathrm{H}, \mathrm{OH}) ;{ }^{13} \mathrm{C}$ NMR (DMSO-d $) \delta \mathrm{ppm}$ : 20,$4 ; 24,5(\mathrm{C}-18) ; 28,1 ; 28,3 ; 28,9 ; 31,7 ; 32,8 ; 40,9 ; 41,1 ; 48,5 ; 49,4 ; 111,9$ és 114,1 (C-1 és C-4); 124,1 és $129,7(\mathrm{C}-5$ és C-10); 134,0(C-2); 142,2(C-3); 220,7(C-17). MS m/z (\%):286 $\left(100,[\mathrm{M}+\mathrm{H}]^{+}\right)$. 
IX. A vegyületek fizikai adatai

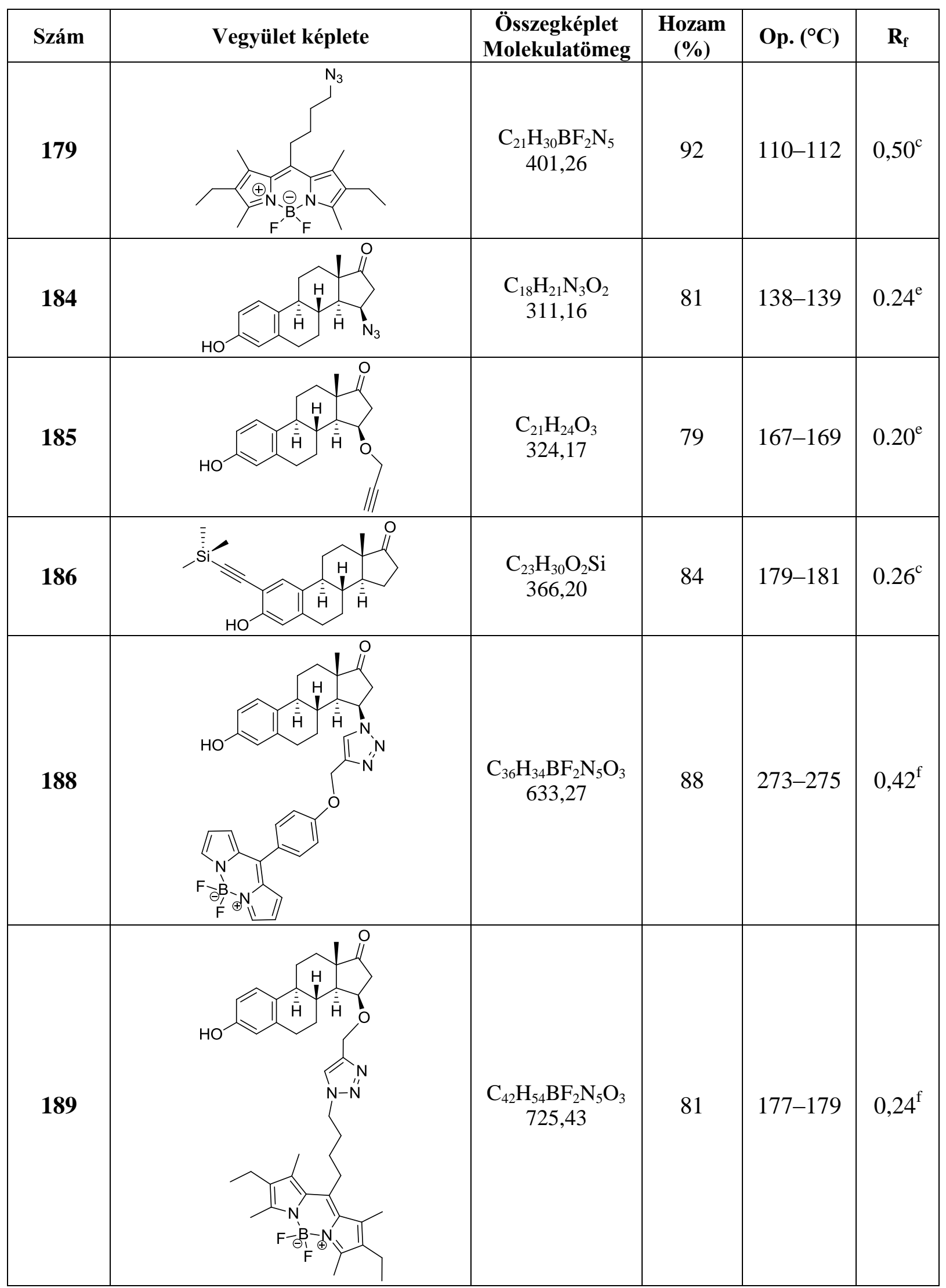




1912




\section{A vegyületek NMR adatai}

$179{ }^{1} \mathrm{H}-\mathrm{NMR}$ (DMSO-d 6 ) $\delta$ ppm: $1,05\left(\mathrm{t}, 6 \mathrm{H}, J=7,5 \mathrm{~Hz}, 2 \mathrm{xCH}_{2} \mathrm{C}_{3}\right.$ ); 1,73-1,80 (átfedő multipletek, 4H); 2,33 és 2,50 (2xs, 2x6H, 4xCH$) ; 2,41$ (q, 4H, $J=7,5 \mathrm{~Hz}, 2 \mathrm{xC}_{2} \mathrm{CH}_{3}$ ); 3,02 $(\mathrm{m}, 2 \mathrm{H}) ; 3,37(\mathrm{~m}, 2 \mathrm{H}) ;{ }^{13} \mathrm{C}-\mathrm{NMR} \delta \mathrm{ppm}: 12,4(2 \mathrm{C}) ; 13,3(2 \mathrm{C}) ; 14,8(2 \mathrm{C}) ; 17,2(2 \mathrm{C}) ; 27,8$; 28,$8 ; 29,2 ; 51,0 ; 130,9 ; 132,7$ (2C); 135,5 (2C); 143,6 (2C); 152,4 (2C). MS m/z (\%): 382 $\left(100,[\mathrm{M}-\mathrm{F}]^{+}\right)$.

$184{ }^{1} \mathrm{H}-\mathrm{NMR}\left(\mathrm{DMSO}_{\mathrm{d}}\right) \delta \mathrm{ppm}$ : 0,89 (s, 3H, 18- $\left.\mathrm{H}_{3}\right) ; 2,76\left(\mathrm{~m}, 2 \mathrm{H}, 6-\mathrm{H}_{2}\right) ; 4,16(\mathrm{~m}, 1 \mathrm{H}, 15-$ $\mathrm{H}) ; 6,44(\mathrm{~d}, 1 \mathrm{H}, J=2,2 \mathrm{~Hz}, 4-\mathrm{H}) ; 6,52(\mathrm{dd}, J=8,6 \mathrm{~Hz}, J=2,2 \mathrm{~Hz}, 2-\mathrm{H}) ; 7,05$ (d, 1H, $J=8,6$ $\mathrm{Hz}, 1-\mathrm{H}) ; 9,04$ (s, 1H, OH); ${ }^{13} \mathrm{C}-\mathrm{NMR} \delta$ ppm: 14,7 (C-18); 25,6; 26,3; 29,0; 31,0; 37,7; 42,0; 43,$1 ; 49,7 ; 53,1 ; 58,1 ; 112,8 ; 114,7 ; 126,3 ; 129,3 ; 136,8 ; 155,0 ; 214,4$.

$185{ }^{1} \mathrm{H}-\mathrm{NMR}\left(\mathrm{DMSO}_{6}\right) \delta \mathrm{ppm}: 1,03\left(\mathrm{~s}, 3 \mathrm{H}, 18-\mathrm{H}_{3}\right) ; 2,75\left(\mathrm{~m}, 2 \mathrm{H}, 6-\mathrm{H}_{2}\right) ; 3,44(\mathrm{~s}, 1 \mathrm{H}$, $\mathrm{C} \equiv \mathrm{CH}) ; 4,11$ and 4,25 (2xm, 2x1H, $\left.\mathrm{OCH}_{2}\right) ; 4,37(\mathrm{t}, 1 \mathrm{H}, J=5,1 \mathrm{~Hz}, 15-\mathrm{H}) ; 6,46(\mathrm{~d}, 1 \mathrm{H}, J=$ 2,2 Hz, 4-H); 6,51 (d, 1H, $J=8,6 \mathrm{~Hz}, J=2,2 \mathrm{~Hz}, 2-\mathrm{H}) ; 7,05$ (d, 1H, $J=8,6 \mathrm{~Hz}, 2-\mathrm{H}) ; 9,03$ (s, $1 \mathrm{H}, \mathrm{OH}) ;{ }^{13} \mathrm{C}-\mathrm{NMR} \delta$ ppm: 17,2 (C-18); 25,3 (2C); 28,9; 32,3; 34,6; 42,3; 43,6; 46,5; 52,9; 55,6 $\left(\mathrm{OCH}_{2}\right) ; 73,1(\mathrm{C}-15) ; 76,9(\mathrm{C} \equiv \underline{\mathrm{CH}}) ; 80,4(\underline{\mathrm{C}} \equiv \mathrm{CH}) ; 112,7(\mathrm{C}-2) ; 114,9(\mathrm{C}-4) ; 125,8(\mathrm{C}-$ 1); 129,9 (C-10); 137,0 (C-5); 154,9 (C-3); 218,6 (C-17).

$186{ }^{1} \mathrm{H}-\mathrm{NMR}\left(\mathrm{CDCl}_{3}\right) \delta$ ppm: $0.26\left(\mathrm{~s}, 9 \mathrm{H}, 3 \mathrm{xSi}-\mathrm{CH}_{3}\right) ; 2.87\left(\mathrm{~m}, 2 \mathrm{H}, 6-\mathrm{H}_{2}\right) ; 5.62(\mathrm{~s}, 1 \mathrm{H}, \mathrm{OH})$; $6.67(\mathrm{~s}, 1 \mathrm{H}, 4-\mathrm{H}) ; 7.25(\mathrm{~s}, 1 \mathrm{H}, 1-\mathrm{H}) .{ }^{13} \mathrm{C}-\mathrm{NMR} \delta \mathrm{ppm}$ : $0.01\left(3 \mathrm{C}, 3 \mathrm{xSi}^{-\mathrm{CH}_{3}}\right) ; 13.8(\mathrm{C}-18)$; 21.6; 25.8; 26.3; 29.5; 31.4; 35.8; 38.1; 43.7; 47.9 (C-13); 50.4; 99.4; 101.3; 106.9, 114.3; $128.5 ; 131.9 ; 139.9 ; 154.8$ (C-3); 220.8 (C-17)

$188{ }^{1} \mathrm{H}-\mathrm{NMR}\left(\mathrm{DMSO}_{6}\right) \delta$ ppm: 1,03 (s, 3H, 18- $\left.\mathrm{H}_{3}\right) ; 5,34\left(\mathrm{~s}, 2 \mathrm{H}, \mathrm{OCH}_{2}\right) ; 5,42(\mathrm{~m}, 1 \mathrm{H}, 15-$ H); 6,32 (d, 1H, $J=2,2 \mathrm{~Hz}, 4-\mathrm{H}) ; 6,50$ (dd, 1H, $J=8,6 \mathrm{~Hz}, J=2,2 \mathrm{~Hz}, 2-\mathrm{H}) ; 6,64$ (m, 2H); 7,01 (m, 2H); 7,03 (d, 1H, J = 8,6 Hz, 1-H); 7,27 (m, 2H); 7,64 (m, 2H); 8,09 (s, 2H); 8,59 (s, $1 \mathrm{H}) ; 9,00(\mathrm{~s}, 1 \mathrm{H}) ;{ }^{13} \mathrm{C}-\mathrm{NMR} \delta$ [ppm]: 14,5 (C-18); 24,4; 28,6; 31,0; 37,7; 43,0; 44,0; 50,0; 53,$2 ; 57,6 ; 61,4 ; 112,8 ; 114,6 ; 115,1$ (2C); 118,9 (2C); 123,4;125,6;126,2;129,1;131,4 (2C); 132,5 (2C); 133,9; 136,5; 142,8; 143,9 (2C); 146,8; 154,9; 160,5; 213,6. MS m/z (\%): $143(100) ; 634\left(80,[\mathrm{M}+\mathrm{H}]^{+}\right)$.

$189{ }^{1} \mathrm{H}-\mathrm{NMR}\left(\mathrm{DMSO}-\mathrm{d}_{6}\right) \delta \mathrm{ppm}: 0,95\left(\mathrm{t}, 6 \mathrm{H}, J=7,5 \mathrm{~Hz}, 2 \mathrm{xCH}_{2} \mathrm{CH}_{3}\right) ; 1,01\left(\mathrm{~s}, 3 \mathrm{H}, 18-\mathrm{H}_{3}\right)$; 2,24 (átfedő multipletek, 4H, $\left.2 \mathrm{xCH}_{2} \mathrm{CH}_{3}\right) ; 2,33$ (átfedő szinguletek, $\left.12 \mathrm{H}, 4 \mathrm{xCH}_{3}\right) ; 2,96$ (m, $\left.2 \mathrm{H}, 6-\mathrm{H}_{2}\right) ; 4,13(\mathrm{~m}, 1 \mathrm{H}, 15-\mathrm{H}) ; 4,41$ és 4,61 (2xd, $\left.2 \mathrm{x} 1 \mathrm{H}, J=12,5 \mathrm{~Hz}, \mathrm{OCH}_{2}\right) ; 4,45(\mathrm{~m}, 2 \mathrm{H})$; $6,39(\mathrm{~d}, 1 \mathrm{H}, J=2,2 \mathrm{~Hz}, 4-\mathrm{H}) ; 6,50(\mathrm{dd}, 1 \mathrm{H}, J=8,6 \mathrm{~Hz}, J=2,2 \mathrm{~Hz}, 2-\mathrm{H}) ; 7,01(\mathrm{~d}, 1 \mathrm{H}, J=8,6$ 
$\mathrm{Hz}, 1-\mathrm{H}) ; 8,10(\mathrm{~s}, 1 \mathrm{H}, \mathrm{C} \equiv \mathrm{CH}) ; 9,01(\mathrm{~s}, 1 \mathrm{H}, \mathrm{OH}) ;{ }^{13} \mathrm{C}-\mathrm{NMR} \delta \mathrm{ppm}: 12,7$ (2C); 14,0 (2C); 14,6 (2C); 16,4; 17,2 (C-18); 25,3; 25,4; 27,2; 28,0; 28,8; 30,0; 32,3; 34,4; 42,6; 43,3; 46,5; 48,9; 53,$0 ; 54,8 ; 61,6 ; 73,0 ; 112,5 ; 114,9 ; 123,9 ; 125,7 ; 130,0$ (3C); 132,2 (2C); 136,0; 136,1; 137,0; 143,9 (2C); 144,3; 154,9 (2C); 218,7. MS m/z (\%): $706\left(100,[\mathrm{M} \mathrm{-} \mathrm{F}]^{+}\right)$.

$191{ }^{1} \mathrm{H}-\mathrm{NMR}\left(\mathrm{CDCl}_{3}\right) \delta$ ppm: 0,95 (s, 3H, 18- $\left.\mathrm{H}_{3}\right) ; 1,01\left(\mathrm{t}, 6 \mathrm{H}, J=7,5 \mathrm{~Hz}, 2 \mathrm{xCH}_{2} \mathrm{C}_{3}\right) ; 2,26$ és 2,47 (2xs, 2x6H, 4xCH $) ; 2,37\left(\mathrm{q}, 4 \mathrm{H}, J=7,5 \mathrm{~Hz}, 2 \mathrm{xC}_{2} \mathrm{CH}_{3}\right) ; 2,90\left(\mathrm{~m}, 2 \mathrm{H}, 6-\mathrm{H}_{2}\right) ; 3,05$

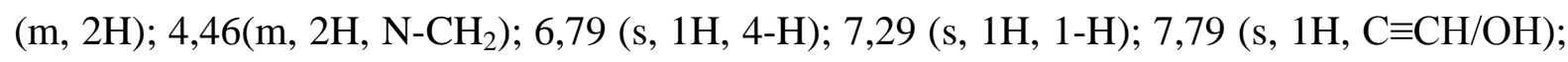
${ }^{13} \mathrm{C}-\mathrm{NMR} \delta$ [ppm]: 12,4 (2C); 13,4 (2C); 13,8 (2C); 14,8 (C-18); 17,1; 21,6; 26,0; 26,4; 27,5; 28,$6 ; 29,2 ; 30,3 ; 31,5 ; 35,9 ; 38,2 ; 43,8 ; 48,0 ; 50,4 ; 50,5 ; 111,5 ; 117,3 ; 118,6 ; 122,6 ; 130,8$ (2C); 131,1; 132,9 (2C); 135,3 (2C); 138,7; 142,9 (2C); 147,9; 152,6; 153,7; 220,9(C-17). MS m/z (\%): $696\left(100,[\mathrm{M}+\mathrm{H}]^{+}\right)$. 